SUBSTITUIÇÃO DO FARELO DE SOJA POR URÉIA OU AMIRÉIA EM DIETAS DE BOVINOS DE CORTE: I. DIGESTIBILIDADE DOS NUTRIENTES, BALANÇO DE NITROGÊNIO, PARÂMETROS RUMINAIS E SANGUÍNEOS; II. DESEMPENHO E III. AVALIAÇÃO DE INDICADORES DE DIGESTIBILIDADE

Tese apresentada àEscola Superior de Agricultura "Luiz de Queiroz", Universidade de São Paulo, para obtenção do título de Doutor em Agronomia, Área de Concentração: Ciência Animal e Pastagens.

PIRACICABA

Estado de São Paulo - Brasil

Dezembro - 2002 


\title{
SUBSTITUIÇÃO DO FARELO DE SOJA POR URÉIA OU AMIRÉIA EM DIETAS DE BOVINOS DE CORTE: I. DIGESTIBILIDADE DOS NUTRIENTES, BALANÇO DE NITROGÊNIO, PARÂMETROS RUMINAIS E SANGUÍNEOS; II. DESEMPENHO E III. AVALIAÇÃO DE INDICADORES DE DIGESTIBILIDADE
}

\section{REINALDO CUNHA DE OLIVEIRA JUNIOR}

Engenheiro Agrônomo

Orientador: Prof. Dr. ALEXANDRE VAZ PIRES

Tese apresentada à Escola Superior de Agricultura "Luiz de Queiroz", Universidade de São Paulo, para obtenção do título de Doutor em Agronomia, Área de Concentração: Ciência Animal e Pastagens.

\author{
PIRACICABA \\ Estado de São Paulo - Brasil \\ Dezembro - 2002
}




\title{
Dados Internacionais de Catalogação na Publicação (CIP) DIVISÃO DE BIBLIOTECA E DOCUMENTAÇÃO - ESALQ/USP
}

\author{
Oliveira J unior, Reinaldo Cunha de \\ Substitutiç ão do farelo de soja por uréia ou a miréia em dietas de bovinos \\ de corte : I. digestibilida de dos nutrintes, balanço de nitrôgenio, parâmetros \\ rumina is e sanguíneos; II. desempenho e III. avaliação de indicadores de \\ digestibilidade / Reinaldo Cunha de Oliveira J unior. - - Pira cicaba, 2002. \\ $198 \mathrm{p}$. \\ Tese (doutora do) - - Esc ola Superior de Agric ultura Luiz de Queiroz, 2002. \\ Bibliografia.
}

1. Amiréia 2. Balanço de nitrogênio 3. Bovino de corte 4. Desempenho animal Dieta animal 6. Digestibilida de - Indic adores 7. Farelo de soja 8. Uréia I. Titulo

CDD636.2085

\section{"Permitida a cópia total ou parcial deste documento, desde que citada a fonte - $\mathrm{O}$ autor"}




\section{Aosmess amados pais REI NALDO \& MI RTIDES,}

Aos meusqueidos imãos Henoch, Patrídia eMária,

Aos meus queridos sdorinhos ] úlia, Manoda, J cãoAntônio, 
"Sábio é o homem que conhece alguma caisa sobre tudo e tudo sobre alguma caisa O mais sábio é aque que estuda como se fosse viver etemamente e vive como se fosse morrer amanhã". 


\section{AGRADECIMENTOS}

Mesmo que passe o tempo e as distâncias sejam inseparáveis, jamais deixarei de lembrar aqueles que me ensinaram, auxiliaram e incentivaram na realização deste trabalho, por isso: Muito obrigado,

A Deus por iluminar sempre o meu caminho e por estar sempre perto.

Ao Prof. Dr. Alexandre Vaz Pires, pela orientação, pelos valiosos ensinamentos, pela amizade, pela confiança e exemplo profissional.

Aos Professores Doutores Flávio A. P. Santos e Ivanete Susin pelos ensinamentos, pelas sugestões na execução deste trabalho, pela atenção e pela amizade.

Aos professores Doutores Wilson Mattos, Luiz Gustavo Nussio, Adib Abdala, Cláudio Haddad, Telma T. Berchielli e Geisa F. Orsine pelos ensinamentos, sugestões na escrita da tese e pela amizade.

À Escola Superior de Agricultura Luiz de Queiroz (USP/ESALQ) e ao Departamento de Zootecnia, pela oportunidade de realização deste curso.

Aos meus pais Reinaldo e Mirtides, æ̀ minhas irmãs Márcia e Patrícia, ao meu irmão Henoch, à minha prima ("irmã") Hérica, aos meus cunhados Carlos Adriano e Elen Carine e aos meus queridos sobrinhos Júlia, Manoela e João Antônio, pela amizade, pelo carinho, pelo apoio e pelo incentivo.

À Janice B. de Morais, pelo companheirismo, pela paciência, incentivo e apoio.

Ao grande amigo e colega de curso Juliano J. R. Fernandes, pela agradável convivência, pelo apoio e por compartilhar os bons e maus momentos. 
Aos meus tios, em especial José Luiz, Noesta e Maria Luiza, pelo incentivo, pela amizade e pelo apoio.

Aos colegas de curso, Márcia Helena M. Rocha e Paulo Garcez pela amizade e pela agradável convivência.

Aos estagiários Ricardo C. D. Goulart e Rafael C. de Araújo, pela amizade e pela valiosa ajuda durante o período experimental.

Ao técnico de laboratório Carlos César Alves, pela amizade, pelos ensinamentos e colaboração nas determinações laboratoriais.

Aos demais funcionários e colegas do curso de pós-graduação pela amizade e agradável convivência.

À CAPES, pela concessão de bolsa de estudos.

À usina Vale do Rosário, pela doação do BTPV.

À Pajoara indústria e comércio, pela doação da amiréia.

Às pessoas que, direta ou indiretamente, contribuíram para a realização deste trabalho. 


\section{SUMÁRIO}

Página

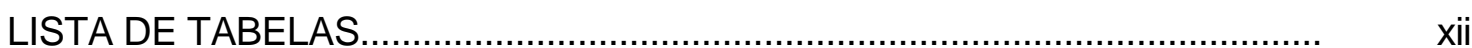

LISTA DE FIGURAS .............................................................................

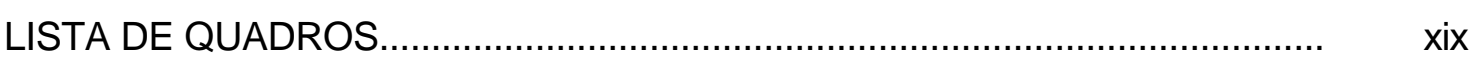

LISTA DE ABREVIATURAS............................................................... $\quad x x$

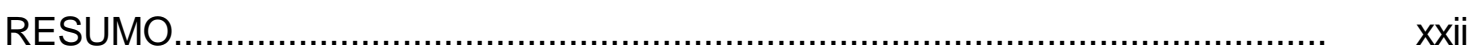

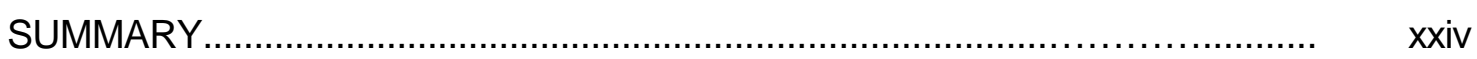

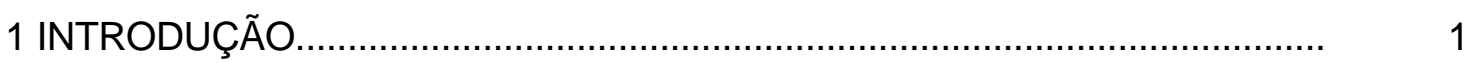

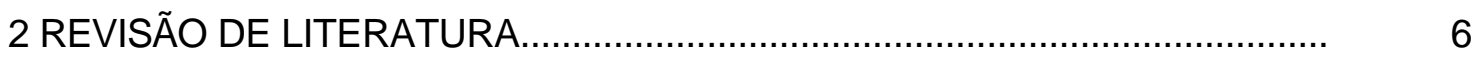

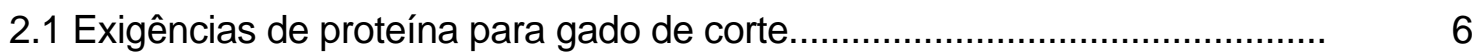

2.2 Resposta microbiana àdegradação ruminal de nitrogênio............................. 13

2.3 Fontes protéicas................................................................................ 15

2.4 Amiréia como fonte de proteína para ruminantes....................................... 23

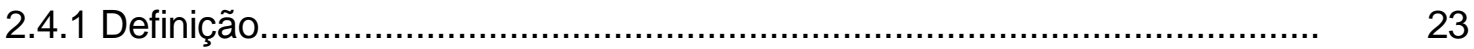

2.4.2 Fatores que podem alterar a qualidade da amiréia.................................... 23

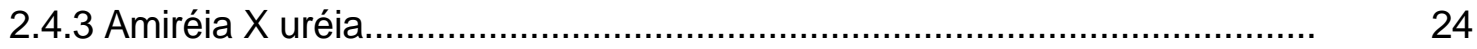

2.4.3.1 Na concentração de amônia ruminal e síntese de proteína microbiana... $\quad 26$

2.4.3.2 Amiréia e processamento de grãos....................................................... 28

2.4.3.2.1 Processamento físico da amiréia.......................................................... 29

2.4.3.3 Na toxidez por amônia..................................................................... 32

2.4.3.4 Na retenção de nitrogênio................................................................ 35

2.4.3.5 No consumo de matéria seca e desempenho...................................... 36

2.4.4 Amiréia X Proteína verdadeira................................................................ 38

2.4.4.1 Na concentração de amônia ruminal e síntese de proteína microbiana... 38

2.4.4.2 No consumo de matéria seca e desempenho..................................... 40 
2.5 Bagaço de cana-de-açúcar in natura em dietas com alto teor de concentrado.

3 SUBSTITUIÇÃO TOTAL DO FARELO DE SOJA POR URÉIA OU AMIRÉIA, EM DIETAS COM ALTO TEOR DE CONCENTRADO, SOBRE A DIGESTIBILIDADE DOS NUTRIENTES, BALANÇO DE NITROGÊNIO, PARÂMETROS RUMINAIS E SANGUÍNEOS EM BOVINOS DE CORTE

Resumo

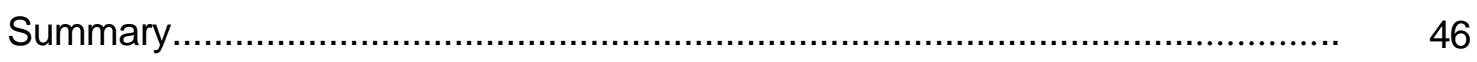

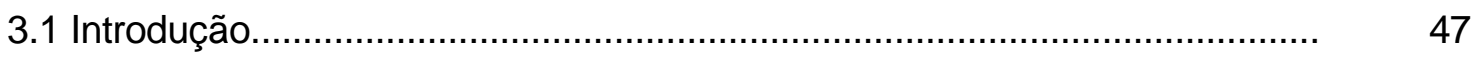

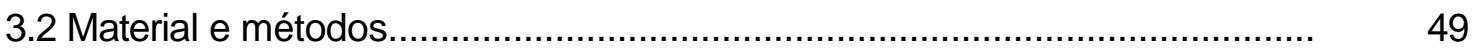

3.2.1 Animais e instalações experimentais..................................................... 49

3.2.2 Tratamentos....................................................................... 50

3.2.3 Período experimental....................................................................... 52

3.2.3.1 Colheita de dados referentes ao consumo de matéria seca.................... 52

3.2.3.2 Colheita de amostras para determinação da digestibilidade aparente no trato digestivo total...................................................................... 53

3.2.3.3 Colheita de amostras para determinação da digestibilidade aparente no rúmen e intestinos..................................................................... 54

3.2.3.4 Análise bromatológica das dietas, sobras e fezes................................... 55

3.2.3.5 Colheita de amostras para determinação do balanço de nitrogênio........ 55

3.2.3.5.1 Colheita de amostras da urina........................................................ 55

3.2.3.6 Colheita de conteúdo ruminal para determinação de ácidos graxos voláteis (AGV), nitrogênio amoniacal $\left(\mathrm{N}^{\left.-\mathrm{NH}_{3}\right)}\right.$ e pH ruminal...................

3.2.3.7 Colheita de sangue para determinação de glicose e nitrogênio uréico

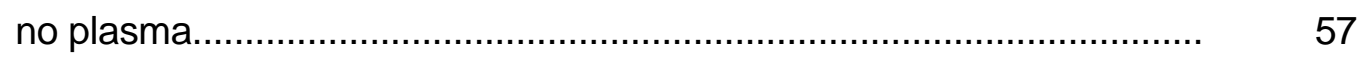

3.2.4 Degradabilidade in situ.................................................................... 58

3.2.5 Simulação da "proteção de cocho" da amiréia......................................... 59

3.2.6 Delineamento experimental e análise estatística........................................ 60

3.3 Resultados e discussão..................................................................... 63

3.3.1 Consumo e digestibilidade dos nutrientes no trato digestivo total................ 63 
3.3.1.1 Matéria seca e matéria orgânica........................................................ 63

3.3.1.2 Fibra detergente neutro e Fibra detergente ácido................................. 66

3.3.1.3 Carboidratos não fibrosos e Proteína bruta............................................... 68

3.3.1.4 Nutrientes digestíveis totais e Extrato etéreo...................................... 71

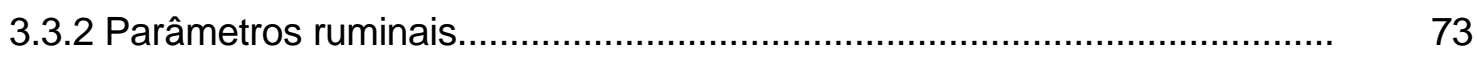

3.3.2.1 $\mathrm{pH}$ do fluido ruminal................................................................. 73

3.3.2.2 Concentração molar dos ácidos graxos voláteis no rúmen...................... 75

3.3.2.2.1 Ácidos graxos voláteis totais............................................................. 75

3.3.2.2.2 Ácido acético......................................................................... 78

3.3.2.2.3 Ácido propiônico.......................................................................... 80

3.3.2.2.4 Ácido butírico............................................................................. $\quad 82$

3.3.2.2.5 Ácidos isobutírico, valérico e isovalérico............................................. 84

3.3.2.2.6 Relação Acético/Propiônico............................................................. 86

3.3.2.3 Concentração de nitrogênio amoniacal no fluido ruminal.......................... 89

3.3.3 Parâmetros sanguíneos................................................................... 92

3.3.3.1 Concentração de nitrogênio uréico no plasma (NUP) sanguíneo............. 92

3.3.3.2 Concentração de glicose no plasma sanguíneo..................................... 95

3.3.4 Metabolismo do nitrogênio................................................................ 97

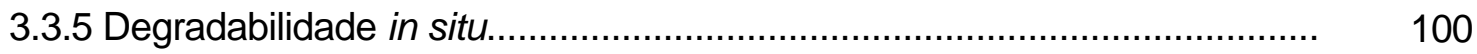

3.3.6 Simulação da "proteção de cocho" da amiréia.......................................... 105

3.4 Conclusões................................................................................................ 106

4 SUBSTITUIÇÃO TOTAL DO FARELO DE SOJA POR URÉIA OU AMIRÉIA, EM DIETAS COM ALTO TEOR DE CONCENTRADO, SOBRE O DESEMPENHO DE BOVINOS DE CORTE CONFINADOS......................... 108

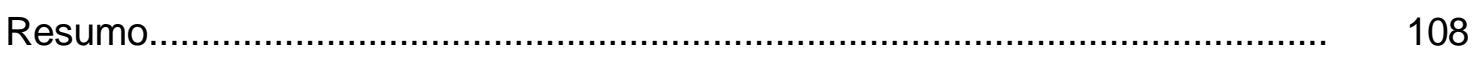

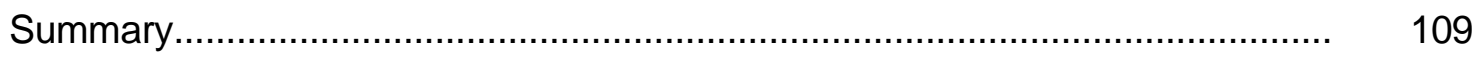

4.1 Introdução............................................................................... 109

4.2 Material e métodos.......................................................................... 111

4.2.1 Animais e instalações experimentais.................................................. 111 
4.2.2 Tratamentos.

4.2.3 Período experimental...................................................................... 114

4.2.3.1 Colheita de dados referentes ao consumo de matéria seca..................... 114

4.2.3.2 Análise bromatológica das dietas e sobras........................................... 115

4.2.3.3 Pesagem dos animais.................................................................... 115

4.2.4 Delineamento experimental e análise estatística..................................... 116

4.3 Resultados e discussão..................................................................... 117

4.3.1 Avaliação dos modelos NRC (1996) e CNCPS (Fox et al., 2000) em raças de bovinos de corte..................................................................... 120

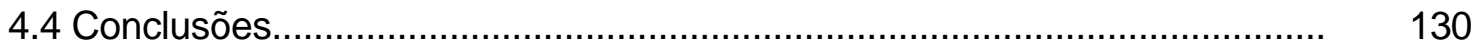

5 SUBSTITUIÇÃO PARCIAL DO FARELO DE SOJA POR URÉIA OU AMIRÉIA, EM DIETAS CONTENDO BAGAÇO DE CANA-DE-AÇÚCAR HIDROLISADO, SOBRE O DESEMPENHO DE BOVINOS CONFINADOS EM TERMINAÇÃO.

Resumo.......

Summary

5.1 Introdução.

5.2 Material e métodos.

5.2.1 Animais e instalações experimentais

5.2.2 Tratamentos.

5.2.3 Período experimental.

5.2.3.1 Colheita de dados referentes ao consumo de matéria seca.

5.2.3.2 Análise bromatológica das dietas e sobras

5.2.3.3 Pesagem dos animais.

5.2.4 Delineamento experimental e análise estatística.

5.3 Resultados e discussão 
6 COMPARAÇÃO DA DETERMINAÇÃO DE CROMO POR FLUORESCÊNCIA DE RAIOS X E INDICADORES INTERNOS PARA ESTIMAR A DIGESTIBILIDADE DOS NUTRIENTES EM NOVILHOS NELORE, ALIMENTADOS COM DIETAS COM ALTO TEOR DE CONCENTRADO E FONTES NITROGENADAS.....

Resumo

Summary

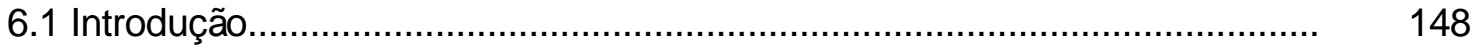

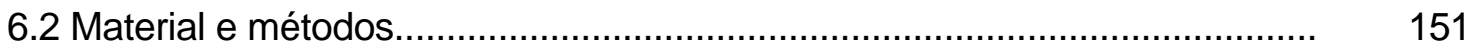

6.2.1 Animais e instalações experimentais.................................................... 151

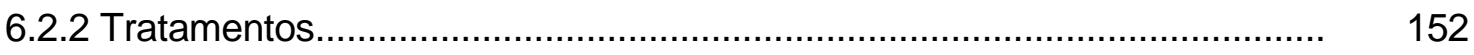

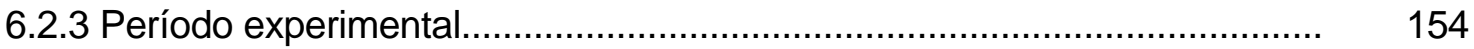

6.2.3.1 Colheita de dados referentes ao consumo de matéria seca................... 154

6.2.3.2 Colheita de amostras para determinação da digestibilidade aparente no

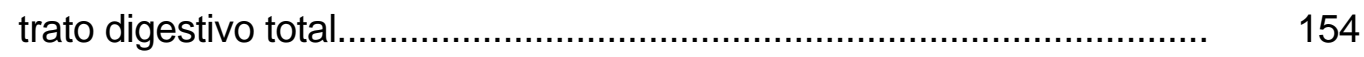

6.2.3.3 Análise bromatológica das dietas, sobras e fezes................................... 156

6.2.4 Delineamento experimental e análise estatística.................................... 156

6.3 Resultados e discussão.................................................................... 157

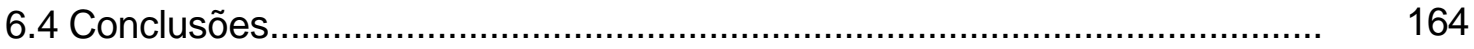

7 CONCLUSÕES GERAIS........................................................................ 166

REFERÊNCIAS BIBLIOGRÁFICAS.............................................................. 168 


\section{LISTA DE TABELAS}

Página

1 Avaliação química relativa das fontes protéicas em relação à proteína do tecido.

2 Metabolismo do farelo de soja (FS) e fontes ricas em proteína não degradável no rúmen (PNDR) para vacas em lactação........................

3 Efeito da fonte nitrogenada no metabolismo e desempenho dos animais

4 Composição em ingredientes e composição química das dietas (\% da MS)

5 Consumo e digestibilidade aparente da matéria seca e matéria orgânica no trato digestivo total em bovinos de corte suplementados com fontes nitrogenadas

6 Consumo e digestibilidade aparente da fibra detergente neutro (FDN) e fibra detergente ácido (FDA) no trato digestivo total em bovinos de corte suplementados com fontes nitrogenadas 
7 Consumo e digestibilidade aparente dos carboidratos não fibrosos (CNF) e proteína bruta (PB) no trato digestivo total em bovinos de corte suplementados com fontes nitrogenadas

8 Consumo e digestibilidade aparente do Extrato etéreo (EE) no trato digestivo total e os valores dos Nutrientes digestíveis totais (NDT) em bovinos de corte suplementados com fontes nitrogenadas.

9 Valores de $\mathrm{pH}$ no fluido ruminal em bovinos de corte suplementados com fontes nitrogenadas

10 Concentração molar dos ácidos graxos voláteis totais no fluido ruminal $(\mathrm{mM})$ em bovinos de corte suplementados com fontes nitrogenadas

11 Concentração molar de acetato no fluido ruminal (mM) em bovinos de corte suplementados com fontes nitrogenadas

12 Concentração molar de propionato no fluido ruminal $(\mathrm{mM})$ em bovinos de corte suplementados com fontes nitrogenadas

13 Concentração molar de butirato no fluido ruminal (mM) em bovinos de corte suplementados com fontes nitrogenadas

14 Concentração molar de isobutírato, valerato e isovalerato no fluido ruminal (mM) em bovinos de corte suplementados com fontes nitrogenadas

15 Relação acetato propionato no fluido ruminal (mM) em bovinos de corte suplementados com fontes nitrogenadas 
16 Concentração de nitrogênio amoniacal no fluido ruminal (mg/dL) em bovinos de corte suplementados com fontes nitrogenadas..

17 Concentração de nitrogênio uréico no plasma sanguíneo $(\mathrm{mg} / \mathrm{dL})$ em bovinos de corte suplementados com fontes nitrogenadas

18 Concentração de glicose no plasma sanguíneo em bovinos de corte suplementados com fontes nitrogenadas.

19 Metabolismo do nitrogênio (N) em bovinos de corte suplementados com fontes nitrogenadas.

20 Composição em ingredientes e composição química das dietas (\% da MS).

21 Composição das frações nitrogenadas das dietas (\% da MS)

22 Desempenho de bovinos de corte confinados e suplementados com fontes nitrogenadas.

23 Avaliação de modelos para predizer o consumo de MS e o desempenho de bovinos da raça Nelore confinados.

24 Avaliação de modelos para predizer o consumo de MS e o desempenho de bovinos da raça Canchim confinados

25 Avaliação de modelos para predizer o consumo de MS e o desempenho de bovinos da raça Holandesa confinados. 
26 Composição em ingredientes e composição química das dietas (\% da MS).

27 Composição das frações nitrogenadas das dietas (\% da MS)

28 Desempenho de bovinos de corte confinados suplementados com fontes nitrogenadas.

29 Composição em ingredientes e a composição química das dietas (\% da MS).

30 Digestibilidade da matéria seca e matéria orgânica determinadas utilizando indicadores e colheita total de fezes em novilhos Nelore suplementados com fontes nitrogenadas.

31 Digestibilidade da fibra em detergente neutro e fibra em detergente ácido determinadas utilizando indicadores e colheita total de fezes em novilhos Nelore suplementados com fontes nitrogenadas.

32 Digestibilidade da proteína bruta e extrato etéreo determinadas utilizando indicadores e colheita total de fezes em novilhos Nelore suplementados com fontes nitrogenadas. 


\section{LISTA DE FIGURAS}

Página

1 Processo de ajuste da produção de proteína microbiana e da degradação ruminal de carboidratos fibrosos por uma deficiência ruminal de nitrogênio.

2 Valores de $\mathrm{pH}$ no fluido ruminal, nos horários de colheita, em bovinos de corte suplementados com fontes nitrogenadas

3 Concentração molar dos ácidos graxos voláteis totais no fluido ruminal, nos horários de colheita, em bovinos de corte suplementados com fontes nitrogenadas.

4 Concentração molar de ácido acético no fluido ruminal, nos horários de colheita, em bovinos de corte suplementados com fontes nitrogenadas.

5 Concentração molar de ácido propiônico no fluido ruminal, nos horários de colheita, em bovinos de corte suplementados com fontes nitrogenadas.

6 Concentração molar de ácido butírico no fluido ruminal, nos horários de colheita, em bovinos de corte suplementados com fontes nitrogenadas. 
7 Relação acetato/propionato no fluido ruminal, nos horários de colheita, em bovinos de corte suplementados com fontes nitrogenadas

8 Concentração de amônia no fluido ruminal, nos horários de colheita, em bovinos de corte suplementados com fontes nitrogenadas

9 Concentração de nitrogênio uréico no plasma sanguíneo, nos horários de colheita, em bovinos de corte suplementados com fontes nitrogenadas.

10 Curvas de degradação da matéria seca (MS) do farelo de soja (FS) e da amiréia (150S), calculadas pelo modelo de Ørskov \& McDonald (1979).

11 Degradação da proteína bruta (PB) do farelo de soja (FS) e da amiréia (150S), calculadas pelo modelo de Ørskov \& McDonald (1979)

12 Relação entre ganho de peso vivo (GPV) observado e o predito pela energia disponível para ganho (EDG) ou proteína metabólica disponível para ganho (PMDG) em $\mathrm{kg} / \mathrm{d}$, através do NRC ( $\boldsymbol{\bullet}$ ) ou CNCPS (o), para animais alimentados com fontes nitrogenadas.........

13 Relação entre ganho de peso vivo (GPV) observado e o predito pela energia disponível para ganho (EDG) ou proteína metabólica disponível para ganho (PMDG) em $\mathrm{kg} / \mathrm{d}$, através do NRC ( $\bullet$ ) ou CNCPS (o), para animais com dieta deficiente em PDR (Tratamento FS). 
14 Relação entre ganho de peso vivo (GPV) observado e o predito pela energia disponível para ganho (EDG) ou proteína metabólica disponível para ganho (PMDG) em $\mathrm{kg} / \mathrm{d}$, através do NRC ( $\bullet$ ) ou CNCPS (o), para animais com dieta PDR ajustadas (via NNP)........... 


\section{LISTA DE QUADROS}

Página

1 Esquema da análise da variância para consumo, digestibilidade dos nutrientes, balanço de nitrogênio e glicose plasmática........................ 61

2 Esquema da análise de variância para $\mathrm{pH}, \mathrm{AGV}, \mathrm{N}-\mathrm{NH}_{3}$ e N-uréico.... 62

3 Parâmetros da degradabilidade in situ, do farelo de soja (FS) e da

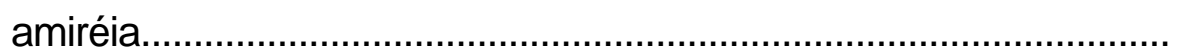

4 Proporção do nitrogênio solúvel da amiréia in natura, em dois

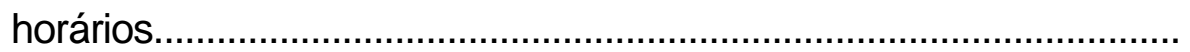




\section{LISTA DE ABREVIATURAS}

"a" - - fração rapidamente solúvel em água

AA - aminoácidos

AAE - aminoácidos essenciais

AGV - ácidos graxos voláteis

AGVCR - ácidos graxos voláteis de cadeia ramificada

"b" - fração insolúvel em água, mas potencialmente degradável

BIN - bagaço de cana-de-açúcar in natura

BTPV - bagaço de cana-de-açúcar tratado sob pressão e vapor

CA - conversão alimentar

CF - carboidratos fibrosos

$\mathrm{CHO}$ - carboidratos

CMS - consumo de matéria seca

CNCPS - Cornell Net Carbohydrate and Protein System

CNF - carboidratos não fibrosos

C2 - ácido acético

C3 - ácido propiônico

DATT - digestibilidade aparente no trato digestivo total

EDG - energia disponível para ganho

EE - extrato etéreo

ELg - energia líquida de ganho

ELm - energia líquida de manutenção

FDA - fibra em detergente ácido 


$\begin{array}{ll}\text { FDN } & \text { - fibra em detergente neutro } \\ \text { FDNi } & \text { - fibra em detergente neutro indigestível } \\ \text { FS } & \text { - farelo de soja } \\ \text { GPV } & \text { - ganho de peso vivo } \\ \text { h } & \text { - hora } \\ \mathrm{Kg}^{0,75} & \text { - quilos de peso metabólico } \\ \text { MM } & \text { - matéria mineral } \\ \text { MO } & \text { - matéria orgânica } \\ \text { NRC } & \text { - National Research Council } \\ \text { MS } & \text { - matéria seca } \\ \text { N } & \text { - nitrogênio } \\ \text { NDT } & \text { - nutrientes digestíveis totais } \\ \text { NH } & \text { - amônia } \\ \text { N-NH } & \text { - nitrogênio amoniacal } \\ \text { NNP } & \text { - nitrogênio não protéico } \\ \text { NUP } & \text { - nitrogênio uréico plasmático } \\ \text { PB } & \text { - proteína bruta } \\ \text { PBM } & \text { - proteína bruta microbiana } \\ \text { PDR } & \text { - proteína degradável no rúmen } \\ \text { PI } & \text { - peso inicial } \\ \text { PM } & \text { - proteína metabolizável } \\ \text { PMDG } & \text { - proteína metabólica disponível para ganho } \\ \text { PNDR } & \text { - proteína não degradável no rúmen } \\ \text { PV } & \text { - peso vivo } \\ \mathrm{R}^{2} & \text { - coeficiente de determinação } \\ & \end{array}$




\section{SUBSTITUIÇÃO DO FARELO DE SOJA POR URÉIA OU AMIRÉIA EM DIETAS DE BOVINOS DE CORTE: I. DIGESTIBILIDADE DOS NUTRIENTES, BALANÇO DE NITROGÊNIO, PARÂMETROS RUMINAIS E SANGUÍNEOS; II. DESEMPENHO E III. AVALIAÇÃO DE INDICADORES DE DIGESTIBILIDADE}

Autor: REINALDO CUNHA DE OLIVEIRA JUNIOR Orientador: Prof. Dr. ALEXANDRE VAZ PIRES

\section{RESUMO}

Com o objetivo de avaliar a substituição de uma fonte de proteína verdadeira (farelo de soja; dieta deficiente em PDR), por uréia ou amiréia (A$150 S$ - fonte de nitrogênio não protéico de suposta liberação gradativa de nitrogênio; dietas adequadas em PDR), foram realizados três experimentos. Experimento I: Seis machos da raça Nelore, não castrados, com peso médio inicial de $420 \mathrm{~kg}$, foram utilizados em quadrado latino $3 \times 3$ duplicado, avaliandose: a digestibilidade, $\mathrm{o}$ balanço de nitrogênio, parâmetros ruminais e sanguíneos (capítulo 3); a estimativa da digestibilidade no trato gastrintestinal utilizando indicadores externo e internos comparados com colheita total de fezes (capítulo 6). O volumoso utilizado foi o BIN (20\% da MS). A digestibilidade da MS, MO, CNF, EE, PB e o NDT não diferiram $(P>0,05)$ entre os tratamentos. A digestibilidade da FDA e FDN foram superiores $(P<0,05)$ nos tratamentos uréia e amiréia. Não houve efeito de tratamento e da interação tratamento $x$ horários $(P>0,05)$ nos valores de $\mathrm{pH}, \mathrm{AGV}$ total, acetato, propionato, butirato e relação acetato:propionato do fluido ruminal. A concentração de nitrogênio 
amoniacal no fluido ruminal foi superior $(P<0,05)$ no tratamento com uréia, comparado ao tratamento com farelo de soja, sendo similar aos dois, o tratamento com amiréia. $O$ tratamento com amiréia apresentou maior $(P<0,05)$ perda de $\mathrm{N}$ na urina. A retenção de $\mathrm{N}$ e o valor biológico da proteína foram superiores $(P<0,05)$ para o tratamento com uréia, comparado aos demais. $A$ concentração de nitrogênio uréico no plasma e a concentração de glicose plasmática foram similares $(P>0,05)$ entre os tratamentos. A estimativa da digestibilidade utilizando o óxido de cromo apresentou resultados similares $(P>0,05)$ à colheita total de fezes. $O$ mesmo foi observado com a lignina no tratamento deficiente em PDR (FS), mas nos de uréia e amiréia, os coeficientes de digestibilidade foram subestimados $(P<0,05)$. A FDNi subestimou $(P<0,05)$ a estimativa da digestibilidade em todas as frações independente do tratamento. A fluorescência de raios- $X$ demonstrou ser uma técnica promissora de análise do cromo (capítulo 6). Experimento II: oitenta e um machos não castrados em crescimento foram utilizados em um delineamento experimental de blocos ao acaso com três tratamentos, tendo três animais por baia e nove baias por tratamento, com a mesma dieta anterior, para avaliar o desempenho dos animais (capítulo 4). O tratamento FS apresentou menor consumo e ganho de peso $(P<0,01)$ e pior $(P<0,01)$ conversão alimentar. Os tratamentos uréia e $A$ 150S não diferiram $(P>0,05)$ entre si. Experimento III: realizou-se outro experimento de desempenho similar ao anterior, utilizando-se apenas outro volumoso ( $45 \%$ de BTPV e $5 \%$ de BIN) e os animais estavam na fase de terminação (capitulo 5). O tratamento $\mathrm{FS}$ apresentou maior $(\mathrm{P}<0,01)$ consumo e ganho de peso e melhor conversão alimentar do que os tratamentos uréia e A150S. Os tratamentos uréia e $A-150$ S não diferiram $(P>0,05)$ entre si. $A$ amiréia promoveu resultados similares a uréia convencional no consumo dos nutrientes, digestibilidade, parâmetros ruminais e sanguíneos e no desempenho de bovinos de corte confinados. 


\title{
REPLACEMENT OF SOYBEAN MEAL BY UREA OR STAREA IN BEEF CATTLE DIET: I. DIGESTIBILITY, NITROGEN BALANCE, RUMINAL AND BLOOD PARAMETERS; II. PERFORMANCE AND III. EVALUATION OF DIGESTIBILITY MARKERS
}

\author{
Author: REINALDO CUNHA DE OLIVEIRA JUNIOR \\ Adviser: Prof. Dr. ALEXANDRE VAZ PIRES
}

\section{SUMMARY}

Experiment I: Six Nellore bulls, with $420 \mathrm{~kg}$ of body weight, were used to evaluate the replacement of a true protein source (soybean meal-SBM), in an inadequate RDP diet, by urea or starea (non protein nitrogen source supposedly of slow $\mathrm{N}$ release), being the last two $\mathrm{N}$ sources in an adequate RDP diet. Sugar cane bagasse in natura (BIN) was the only source of diet forage $(20 \%$ of $\mathrm{DM})$. This trial evaluated: digestibility, ruminal parameters, ruminal ammonia, blood parameters and $\mathrm{N}$ balance (chapter 3 ); total tract digestibility estimated by using internal and external markers compared to total feces collection (chapter 6). DM, OM, NFC, EE, CP and TDN digestibilities (\%) did not differ $(P>0.05)$ among treatments. ADF and NDF digestibilities (\%) were higher $(P<0.05)$ for urea and starea treatments. There was no treatment or treatment $\mathrm{X}$ time effect $(\mathrm{P}>0.05)$ on $\mathrm{pH}$, total VFA, acetate, propionate, butirate and acetate:propionate ratio. Ruminal ammonia $\mathrm{N}$ concentration was greater 
$(P<0.05)$ for urea compared to soybean meal and starea was similar to both. Starea treatment had the higher $(P>0.05)$ urinary $N$ loss. $N$ retention $(g / d$ and \% of ingested) and protein biological value ( $\mathrm{N}$ retention, \% of $\mathrm{N}$ digestible) were higher $(P<0.05)$ for urea treatment. Plasma urea nitrogen and glucose concentrations were similar $(P>0.05)$ among treatment (chapter 3$)$. The digestibility estimated by using cromium oxide was similar $(P>0.05)$ to that of using total feces collection. Lignin used as an internal marker resulted in similar pattern as feces collection when the diet contained soybean meal (RDP deficient diet), however, when the diet $\mathrm{N}$ was urea or starea, the digestibility coefficients were underestimated $(P<0.05)$. The NDFi underestimated $(P<0.05)$ the digestibility of all portion independent of treatment. X-ray fluorescence showed be a promising technique for cromium determination (chapter 6). Experiment II: Eighty-one growing intact males were used in a totally random block design, with three treatments (three animals/pen and nine pens/treatment) to evaluate beef cattle performance in feedlot (chapter 4). Diets were the same used in Exp. I. DM intake, ADG and feed conversion were 6.56, 7.18 and $6.97 \mathrm{~kg} /$ day; 0.889, 1.114 and $1.088 \mathrm{~kg} /$ day and $7.3,6.5$ and $6.7 \mathrm{~kg} \mathrm{DM} / \mathrm{kg}$ gain, for SBM, urea and starea, respectively. SBM treatment had the smaller $(P<0.01) D M$ intake, ADG and feed conversion. Urea and starea treatment were similar $(P>0.05)$. Experiment III: Another performance trial was done (chapter 5), similar to Exp. II, differing only by the forage portion of the diet $(45 \%$ hidrolized sugar cane bagasse-BTPV and $5 \%$ bagasse in natura-BIN) for finishing cattle. DM intake, ADG and feed conversion were 8.99, 7.43 and $7.69 \mathrm{~kg} / \mathrm{day} ; 0.983,0.368$ and $0.404 \mathrm{~kg} /$ day and $9.56,20.14$ and $19.54 \mathrm{~kg} \mathrm{DM} / \mathrm{kg}$ gain for SBM, urea and starea treatments, respectively. SBM had the higher $(\mathrm{P}<0.01) \mathrm{DM}$ intake and $A D G$ and better feed conversion compared to urea and starea. Urea and starea treatments were similar $(P>0.05)$. Starea showed similar results to urea. 


\section{INTRODUÇÃO}

Vários estudos vêm sendo realizados na tentativa de se avaliar os efeitos da manipulação da nutrição protéica, devido àsua importância no metabolismo e desempenho de bovinos. Ênfase tem sido dada a estudos sobre o teor de proteína bruta da dieta, degradabilidade ruminal das fontes protéicas e mais recentemente, o balanço de aminoácidos essenciais das fontes protéicas.

O modelo de proteína metabolizável proposto no NRC (1996) divide as estimativas das exigências protéicas em proteína degradável no rúmen (PDR), a qual deve suprir as exigências dos microrganismos ruminais e proteína não degradável no rúmen (PNDR), a qual deve complementar a proteína microbiana que chega no intestino. Esse modelo foi um avanço, pois sabe-se que é de fundamental importância a síntese de proteína microbiana e, para que esta ocorra, é necessário que se tenha PDR, em quantidade e qualidade $\left(\mathrm{NH}_{3}\right.$, peptídeos e aminoácidos; Russell et al., 1992) para ter-se a máxima eficiência. As exigências de proteína do NRC (1996) geralmente são superiores a do NRC (1984) devido, principalmente, ao componente microbiano (PDR).

As bactérias fermentadoras de fibras utilizam amônia como fonte preferencial de $\mathrm{N}$, sendo estas altamente prejudicadas quando há deficiência de nitrogênio no rúmen, levando a um menor desaparecimento da fibra, diminuindo a taxa de passagem e, conseqüentemente, diminuindo o consumo de matéria seca (Russell et al., 1983, 1992 e Tedeschi et al., 2000). Esta amônia pode ser fornecida via uréia, embora, apresente uma alta solubilidade no rúmen, limitando o seu uso. Uma maneira de melhorar esse problema é o emprego de 
complexos de liberação lenta de uréia (Owens \& Zinn, 1988), como a amiréia, melhorando o fornecimento de amônia no rúmen aumentando a síntese de proteína microbiana, o consumo de matéria seca, a digestibilidade da fibra e por tanto proporcionando maior consumo de energia pelo animal, além de reduzir problemas com toxidez (Bartley \& Deyoe, 1975).

A união do grão de cereal e uréia em condições apropriadas de calor, pressão e umidade, por um determinado tempo (que é utilizado no processo de fabricação da amiréia), resulta em uma combinação da uréia com o grão de amido. Neste processo, o grão é gelatinizado e com isso, aumenta sua acessibilidade æ̀s enzimas do conteúdo ruminal, aumentando sua degradação ruminal e tornando-a mais próxima (sincronizando) da taxa de liberação de amônia pela uréia.

Com a gelatinização do amido, observa-se aumento na proporção de ácido propiônico e uma redução na proporção de ácido acético, sendo a produção total de ácidos graxos voláteis totais aumentada e a concentração de amônia ruminal reduzida (Wilson \& Woods, 1966; 1967 e Mendes Junior, 1999), podendo promover uma maior síntese de proteína microbiana quando se utiliza amiréia (amido gelatinizado) (Helmer et al., 1970b e Barr et al., 1975).

Alguns autores comparando uréia e amiréia na retenção de nitrogênio utilizando borregos, observaram maior retenção de nitrogênio no tratamento com amiréia (Shiehzadeh \& Harbers, 1974), no tratamento com uréia (Silva et al., 1994) ou não observaram diferenças (Salman et al., 1997). Em vacas lactantes, Teller et al. (1982) e Teller \& Godeau (1986) não observaram diferenças no balanço de nitrogênio. Esses resultados não seguem uma mesma lógica (falta consistência), não permitindo uma conclusão do assunto.

Faltam trabalhos que avaliem 0 balanço de nitrogênio em bovinos, pois a amiréia apresenta uma fonte de amido com alta taxa de degradação e uma suposta liberação mais lenta de amônia. Com isso, é de se 
esperar maior síntese de proteína microbiana, a qual apresenta alto valor biológico, e portanto, maior retenção de nitrogênio.

As concentrações de uréia sanguínea têm sido utilizadas para monitorar o consumo de proteína dietética (teor e degradabilidade ruminal) próximo æ̀s exigências do animal, já que o consumo excessivo de proteína pode afetar o desempenho reprodutivo do animal, aumentando sua exigência em energia ou ainda, o custo da ração (Broderick \& Clayton, 1997). Sendo assim, é importante avaliar a uréia sanguínea quando utiliza fontes protéicas com diferentes degadabilidades ruminais.

Alguns experimentos têm demonstrado que não há diferença na concentração ruminal de amônia quando compara amiréia com uma mistura de uréia mais grão extrusado (Helmer et al., 1970b e Stiles et al., 1975a). Neste sentido, Bartley et al. (1976) observaram uma correlação significativa $(r=-0,22)$ entre grau de gelatinização do amido e amônia ruminal.

Utilizando novilhos em terminação, Stiles et al. (1975a) observaram menor concentração de amônia ruminal no tratamento com amiréia quando comparada a uma mistura uréia mais sorgo moído grosso (quebrado), após sete dias de alimentação. A amiréia proporcionou valores que não diferiram da mistura uréia mais sorgo moído fino ou sorgo extrusado. Com isso, torna-se necessário avaliar melhor as supostas vantagens da amiréia quanto a sua liberação gradativa de amônia, promovendo uma redução na amônia ruminal e uma "proteção de cocho", reduzindo os possíveis riscos de intoxicação dos animais.

O uso de dietas de alto teor de concentrado fornecido ad libitum é prática comum na indústria de gado de corte norte-americana (Preston, 1998). No Brasil, as dietas de animais em confinamento são tradicionalmente balanceadas com altas proporções de volumosos. Em épocas de preços vantajosos de concentrados, dietas de alto teor de concentrado têm se tornado viáveis economicamente, já que o ganho de peso é mais rápido, havendo redução no custo de mão-de-obra e tornando a atividade mais rentável. Neste 
tipo de dieta, a fonte de volumoso entra apenas com a função de estimular a ruminação e salivação, bem como formar uma malha de fibra no rúmen, aumentando o tempo de permanência do alimento. Este efeito é obtido pela chamada fibra íntegra (Bulle, 2000). Neste contexto, o bagaço de cana-deaçúcar in natura vem demonstrando ser uma fonte de fibra interessante (Henrique et al., 1999 e Bulle et al. 2002a).

O bagaço tratado sob pressão e vapor, quando utilizado em dietas para confinamentos, tem proporcionado desempenhos satisfatórios (Lanna \& Boin, 1990; Nussio et al., 1990; Santos, 1991; Nussio, 1993 e Rabelo, 2002). No entanto, para se ter condições ruminais adequadas é necessário adicionar uma fonte de fibra íntegra, como o bagaço in natura (Nussio, 1993 e Rabelo, 2002) ou ponta de cana picada (Hausknecht, 1996).

Várias substâncias são sugeridas como indicador de fluxo, porém, nenhuma delas é perfeita, mas apresentam características suficientemente adequadas para fornecer dados significativos. Por esta razão, a procura de indicadores ideais constitui um dos assuntos de grande interesse na pesquisa de técnicas que facilitem estudos de nutrição animal.

A busca de métodos mais simples para a determinação da digestibilidade conduziu ao emprego dos indicadores ou marcadores que podem proporcionar uma série de informações, incluindo: a quantidade consumida de alimento ou nutriente específico; a taxa de passagem da digesta através de todo ou parte do trato digestivo e a digestibilidade de todo alimento ou de nutrientes específicos (Oliveira et al., 1991).

A digestibilidade in vivo é influenciada por efeitos associativos, nível de consumo, taxa de passagem e interações destes fatores e, por isso, freqüentemente é difícil imitar essas condições in vitro (Conchran et al., 1986). Nessas condições, a estimativa da digestibilidade intermediada por indicadores pode ser desejável (Van Soest, 1994). Constituintes naturais da dieta que apresentam baixa digestibilidade têm sido utilizados como indicadores. Os indicadores internos apresentam a vantagem de já estarem presentes no 
alimento e, de modo geral, permanecem distribuídos na digesta durante o processo de digestão e excreção (Piaggio et al., 1991).

Os objetivos do presente trabalho foram comparar o efeito da substituição de uma fonte de proteína verdadeira (farelo de soja), por uréia ou amiréia (fonte de nitrogênio não protéico de suposta liberação gradativa de nitrogênio) em bovinos de corte: na digestibilidade, balanço de nitrogênio, parâmetros ruminais e sanguíneos (capítulo 3); no desempenho sendo o BIN a única fonte de volumoso ( $20 \%$ da MS; capítulos 4 ); no desempenho utilizando o BTPV (45\%) e o BIN (5\% da MS) como volumosos (capítulos 5) e; na estimativa da digestibilidade no trato gastrintestinal utilizando indicadores externo e internos comparados àcolheita total de fezes (capítulo 6). 


\section{REVISÃO DE LITERATURA}

\subsection{Exigências de proteína para gado de corte}

A proteína tem um papel fundamental na nutrição de ruminantes, sendo sua essencialidade não apenas pelo fornecimento de aminoácidos para o animal, mas também como fonte de nitrogênio para síntese de proteína microbiana. Com base nesse conhecimento, a proteína bruta (PB) da dieta deve ser composta de duas frações: uma degradável no rúmen (PDR) e outra de proteína não degradável no rúmen (PNDR). As proporções dessas duas frações vão depender do valor energético da ração e da exigência total de proteína pelo animal.

O NRC (1984) calcula a exigência de proteína pelo método fatorial, onde considera quatro fatores: nitrogênio $(\mathrm{N})$ metabólico fecal, proteína líquida depositada no ganho e as perdas de $\mathrm{N}$ endógeno na urina e por descamação. A exigência de proteína bruta da dieta é calculada e corrigida para digestibilidade verdadeira (90\%) e absorção de aminoácidos (66\%). Estas estimativas foram alteradas no NRC (1996), onde as exigências de proteína foram divididas em exigência animal e exigência dos microganismos ruminais. Isso foi um avanço, pois sabe-se que é de fundamental importância a síntese de proteína microbiana e, para que esta ocorra, é necessário que se tenha proteína degradável no rúmen (PDR) em quantidade e qualidade (amônia $\mathrm{NH}_{3}$, peptídeo e aminoácidos), com o objetivo de atingir a máxima eficiência (Russell et al., 1992). As exigências de proteína do NRC (1996) geralmente são 
superiores as do NRC (1984) devido, principalmente, ao componente microbiano (PDR).

O NRC (1996) calcula a exigência de proteína degradável no rúmen em função da produção estimada de proteína microbiana, sendo a produção de proteína microbiana $13 \%$ dos nutrientes digestíveis totais (NDT) (1 $\mathrm{kg}$ de PB microbiana (PBM) $=1 \mathrm{~kg}$ PDR). Por outro lado, Zinn \& Shen (1998) comentaram que este método de calcular a exigência de PDR é conservadora, porque o fluxo de $\mathrm{N}$ microbiano só reduz quando a PDR é menor que 70 a $80 \%$ do fluxo de $\mathrm{N}$ bacteriano para o intestino, recomendando um mínimo de $100 \mathrm{~g}$ de proteína degradável no rúmen por kg de matéria orgânica $(\mathrm{MO})$ digestível (0,7 a $0,8 \mathrm{~kg}$ PDR $=1 \mathrm{~kg}$ PBM).

O valor de $13 \%$ do NDT para estimar a produção de proteína microbiana é um valor médio para a maioria das dietas, entretanto, estava implícito que esta recomendação não é apropriada para animais consumindo forragem de baixa qualidade ou dieta com concentrados extremamente altos (NRC, 1996 e Mathis et al., 2000).

Mathis et al. (2000), comparando diferentes porcentagens de PDR em três forragens de baixa qualidade: Cynodon spp (8,2\% de PB e $71 \%$ de fibra detergente neutro - FDN), Bromus spp (5,9\% de PB e $65 \%$ de FDN) e feno de sorgo forrageiro (4,3\% de PB e $60 \%$ de FDN), observaram que a porcentagem de PDR, em função da $\mathrm{MO}$ digestível para maximizar o consumo de MO digestível, foi 8,2\% para Cynodon spp, 9,8\% para Bromus spp e 12,8\% para o sorgo forrageiro (maior teor testado). Os autores apontam para a reciclagem de $\mathrm{N}$ um importante fator que deve ser considerado, contribuindo para o "pool" de $\mathrm{N}$ degradado no rúmen, razão pela qual, a quantidade de PDR consumida para alcançar o máximo consumo de forragem e digestibilidade variou de 8 a $13 \%$ do total de MO digestível.

Thiago \& Silva (2001) sugeriram que animais consumindo pastagens com uma composição química igual a 5\% de PB e $51 \%$ de NDT, é necessário o equivalente a $11,8 \%$ do NDT consumido em proteína degradável 
no rúmen, valor inferior ao recomendado pelo NRC (1996), provavelmente devido a baixa concentração energética da dieta.

Foi considerado no NRC (1996) nível 1 que a reciclagem de $N$ é igual às perdas de $\mathrm{N}$ no rúmen, quando as exigências de PDR (13\% do NDT) são satisfeitas, ressaltando que isto não é valido para dietas com teor de concentrado extremamente altos ou com forragens de baixa qualidade.

A quantidade de $\mathrm{N}$ reciclado em ruminantes pode ser influenciada por vários fatores da dieta, tais como: consumo de matéria seca (Sarraseca et al., 1998), consumo de carboidratos rapidamente ermentáveis (Huntington, 1989 e Theurer et al., 2002), teor de concentrado na dieta (Huntington et al., 1996), teor de $\mathrm{N}$ na dieta (Bunting et al., 1987; Ferrell et al., 2001 e Archibeque et al., 2001), fonte suplementar de N (Ferrell et al., 2001) e quantidade de PNDR que chega ao intestino (Van Soest, 1994).

A reciclagem de $\mathrm{N}$ é de importância substancial para a economia de $\mathrm{N}$ em ruminantes alimentados com dietas contendo altos teores de grãos, podendo ser mais importante quando a dieta apresenta baixa concentração de $\mathrm{N}$. Uma quantidade significativa e variável de $\mathrm{N}$ reciclado é o maior problema para a estimativa da exigência de $\mathrm{N}$ na dieta para o animal (Ferrell et al., 2001).

Theurer et al., (2002) observaram que a transferência de nitrogênio uréico para o "portal-drained viscera" (PDV) foi $40 \%$ superior $(P<0,07)$ com milho floculado em relação ao laminado, em bovinos de corte. Os autores sugerem que o aumento da reciclagem de $\mathrm{N}$ para o rúmen pode promover uma maior síntese de proteína microbiana.

Mizwicki et al. (1980) avaliaram o efeito da liberação lenta de amônia sobre a digestibilidade ruminal da matéria seca e a retenção de nitrogênio utilizando taxas de liberação de amônia contínua (3,5 g uréia/h, por $24 \mathrm{~h}$ ), moderada (14,2 g uréia/h, por 6 h) e rápida (85,0 g de uréia, em 1 h) comparadas ao controle (sem uréia). Os autores observaram que a liberação contínua e o controle promoveram uma concentração molar de amônia ruminal estável (12,8 e 1,6 mg/dL, respectivamente). A liberação moderada e rápida 
teve picos de 6,5 e 1,5 h após a alimentação $(37,1$ e $41,8 \mathrm{mg} / \mathrm{dL}$, respectivamente). A digestibilidade da matéria seca foi superior com a suplementação de uréia comparada ao controle, mas não foi observado efeito $(P>0,05)$ entre as taxas de liberação de amônia sobre a digestibilidade da matéria seca, $\mathrm{pH}$ ruminal, balanço de nitrogênio e síntese de proteína microbiana. Os autores sugeriram que a reciclagem de nitrogênio pode ter sido adequada para manter a digestibilidade ruminal e o crescimento microbiano. Não estando os dados de acordo com a teoria em que a liberação lenta de amônia promove benefícios metabólicos.

Tedeschi (2001), suplementando bovinos de corte com uréia e Optigen ${ }^{\circledR}$ (fonte de NNP de suposta liberação gradativa de N) ou combinações de ambas, em uma dieta com ato teor de forragem (mais de $95 \%$ de silagem de milho) ou em outra com alta proporção de concentrado (mais de $85 \%$ ), sendo as duas deficientes em PDR, não observou alterações no desempenho de bovinos de corte confinados em crescimento ou terminação.

Observa-se com dados demonstrados anteriormente, que 0 sistema de reciclagem de nitrogênio no rúmen se adapta facilmente à rapidez da liberação de amônia pelas fontes de nitrogênio não protéico, desde que as concentrações não atinjam níveis tóxicos (Owens \& Zinn, 1988).

Ruminantes consumindo forragem de baixa qualidade apresentam habilidade de manter desempenhos aceitáveis quando não são suplementados diariamente, ou são 12, 24 ou 48 horas (Hunt et al., 1989); a cada 1 ou 3 vezes por semana (Huston et al., 1999); ou a cada 3 ou 6 dias (Bohnert et al., 2002), comparados com a suplementação diária. Essa habilidade pode ser devido à capacidade do ruminante em conservar $\mathrm{N}$ por um período prolongado, alterando a permeabilidade do trato gastrintestinal ao $\mathrm{N}$ uréico e/ou a regulação renal da excreção de uréia e mantendo o $\mathrm{N}$ eficientemente entre períodos de suplementação (Bohnert et al., 2002).

Pode-se verificar, com base nos dados citados anteriormente, que as estimativas de exigências protéicas, principalmente a PDR, serão 
efetivamente atendidas com uma melhor compreensão da reciclagem de $\mathrm{N}$ e da possível habilidade dos ruminantes em conservá-lo.

Polan (1992) comentou que a estimativa de produção de proteína bacteriana no NRC é em função da energia líquida de lactação (ELL) ou NDT consumido, ambos com um $\mathrm{R}^{2}=0,77$. Isto implica que $77 \%$ da produção de proteína microbiana é explicada pelo NDT, tendo uma variação inexplicada de $23 \%$. Dois fatores da dieta podem contribuir para estas variações inexplicáveis: 1) a proteína solúvel pode ser inadequada para suportar o máximo metabolismo microbiano; 2) gordura adicionada à dieta. A gordura entra no cálculo do NDT, mas não é utilizada no rúmen como fonte de energia, não contribuindo para a produção de proteína microbiana.

As recomendações do NRC (1996) propõem equações empíricas para estimar o fluxo de proteína microbiana proveniente do rúmen e apresentam algumas limitações: 1) o crescimento microbiano é em função do NDT e não dos carboidratos disponíveis no rúmen; 2) o crescimento microbiano é constante; 3) a relação fundamental entre produção microbiana e exigência energética dos microrganismos são ignoradas; 4) a população microbiana não é dividida de acordo com a atividade metabólica e exigência nitrogenada; 5) a taxa de fermentação dos carboidratos não é integrada com a taxa de degradação da proteína e 6) a degradação dos alimentos é fixa, não alterando com o consumo e taxa de passagem. O "Cornell Net Carbohydrate and Protein System" (CNCPS) tem um sub-modelo ruminal que inclui todos esses fatores (Russell et al., 1992; Sniffen et al., 1992 e Fox et al., 1992).

Alguns fatores podem alterar a recomendação do teor de proteína na dieta de animais em confinamentos segundo Galyean, (1996), tais como: 1) lotes muito grandes (100 ou mais animais) com grandes variações no tamanho dos animais implica em nivelar a exigência de proteína pelos animais menores, a fim de não limitar o seu desempenho; 2) a mistura e a distribuição dos alimentos também podem afetar o teor de proteína da dieta (um teor maior de proteína poderia compensar as variações ocorridas no dia a dia); 3) fatores 
de manejo que contribuem para redução no consumo de matéria seca (CMS) (ex.: grãos extensivamente processados e ionóforos), necessitando de uma porcentagem superior de proteína na formulação, para que as exigências do animal ( $\mathrm{g} / \mathrm{d}$ ) não sejam alteradas; 4) efeitos do programa de implantes, particularmente aqueles baseados em combinações de estrógenos e androgênicos (acetato de trembolona), aumentando o crescimento protéico (músculo) diário. Este efeito é evidenciado principalmente no início da fase de terminação quando o crescimento protéico (músculo) é rápido, coincidindo com a fase inicial do implante. Assim, o teor de proteína pode ser reduzido no final do período de terminação sem afetar o desempenho, mas nunca menor que $10 \%$; 5) efeito de tamponamento da amônia no rúmen.

Huntington et al. (2001) observaram que o implante de Synovex $S^{\circledR}$ (Fort Dodge Animal Healt, For Dodge, IA) interagiu com o consumo de PB, aumentando o ganho de peso vivo (GPV) e reduzindo a excreção de uréia, especialmente em situações de alto consumo protéico.

Em dieta com deficiência de proteína degradável, há casos em que a energia metabolizável (EM) é o primeiro nutriente limitante. A limitação de $\mathrm{N}$ também causa uma superestimação da EM disponível para ganho, pois reduz a digestibilidade dos carboidratos fibrosos (CF). Entretanto, a superestimação mais comum é a de proteína metabolizável ( $\mathrm{PM}$ ) disponível para ganho (Tedeschi et al., 2000). As bactérias fermentadoras de carboidratos não fibrosos (CNF) utilizam $66 \%$ do $\mathrm{N}$ proveniente de peptídeos ou aminoácidos e $34 \%$ proveniente da amônia. Quando os peptídeos e aminoácidos não são disponíveis em quantidade, todo $\mathrm{N}$ é proveniente da amônia (Russell et al., 1992).

No modelo de Cornell (CNCPS) a produção de bactérias fermentadoras de CNF aumenta em 18,7\% quando a relação peptídeo para CNF aumenta de 0 a 14\% no fluido ruminal. Já as bactérias fermentadoras de CF utilizam amônia como única fonte de $\mathrm{N}$, sendo estas altamente prejudicadas quando há deficiência de $\mathrm{N}$ no rúmen, levando a um menor desaparecimento de 
$\mathrm{CF}$, diminuindo a taxa de passagem e, conseqüentemente, diminuindo o consumo (Figura 1; Russell et al., 1983, 1992 e Tedeschi et al., 2000).

Em animais alimentados com dietas de alto teor de grãos (CNF), é de se esperar que a síntese e eficiência de proteína microbiana aumentem quando há suplementação com fontes de proteína verdadeira. Entretanto, uma fonte de proteína verdadeira de baixa degradabilidade diminui a disponibilidade de AA e peptídeos para os microrganismos. A uréia, em contraste com uma fonte de proteína verdadeira, proporciona rápida disponibilidade de $\mathrm{N}$, aumentando a síntese e eficiência da proteína microbiana (Griswold et al., 1996 e Devant et al., 2001).

Dietas com alto teor de concentrado e alta concentração de milho têm demonstrado que os peptídeos (e/ou aminoácidos) do milho devem proporcionar uma máxima síntese e eficiência de proteína microbiana (Milton et al., 1997b; Fu et al., 2001 e Knaus et al., 2001). Nessas dietas, Knaus et al. (2001) propõem que a uréia pode ser utilizada eficientemente como a única fonte suplementar de $\mathrm{N}$ para suprir a exigência de PDR. Os mesmos autores demonstraram ser eficiente o uso do modelo do NRC (1996) para formular dietas, promovendo uma eficiente utilização de $\mathrm{N}$ para animais em crescimento, evitando uma superalimentação com proteína e um retorno desnecessário de $\mathrm{N}$ para o ambiente (poluição ambiental). 


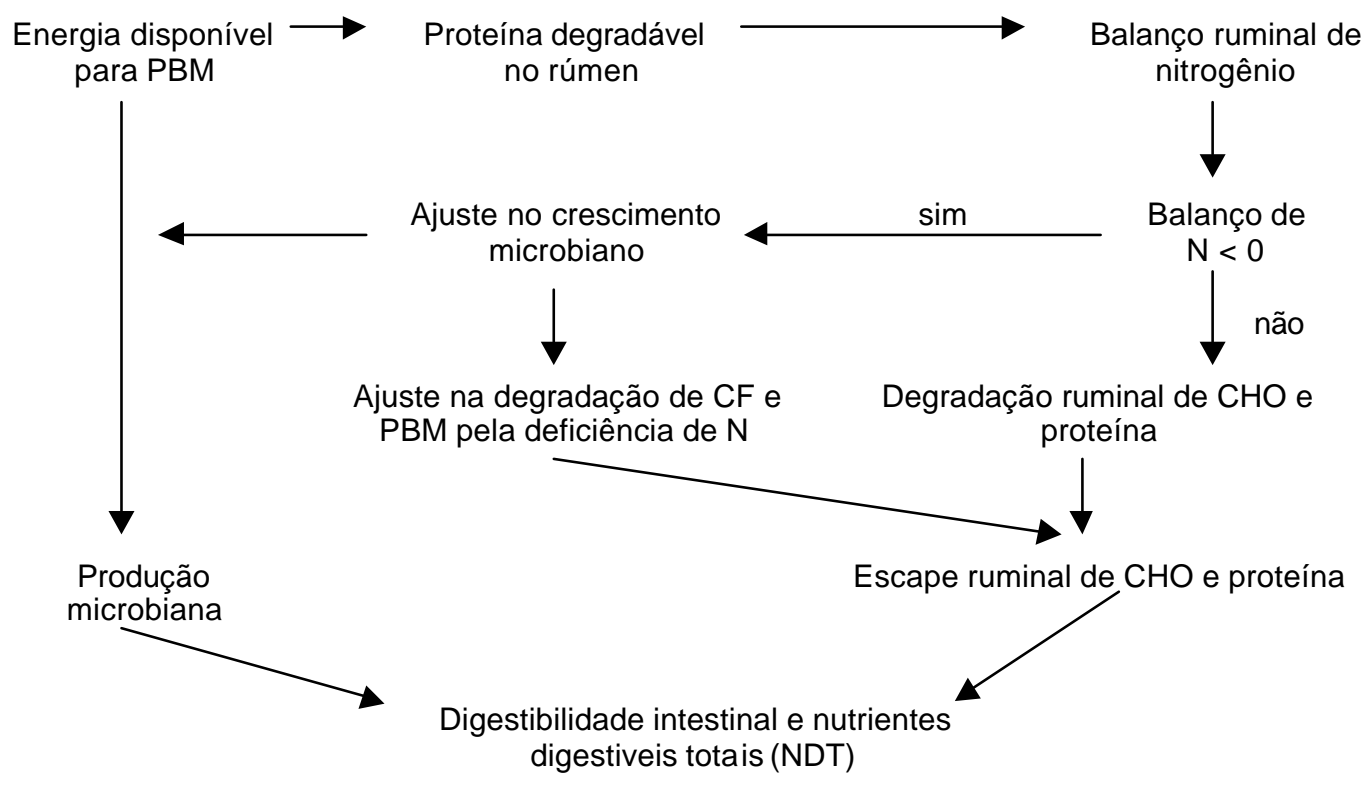

Figura 1 - Processo de ajuste da produção de proteína microbiana e da degradação ruminal de carboidratos fibrosos por uma deficiência ruminal de nitrogênio (adap. Tedeschi et al., 2000).

\subsection{Resposta microbiana à degradação ruminal de nitrogênio}

Muitas pesquisas (citadas previamente) sugerem que o máximo benefício da suplementação protéica é observado quando se utiliza fontes que podem ser degradadas extensivamente no rúmen (por exemplo: farelo de soja, uréia, ou combinações de ambas), atendendo as exigências de PDR.

As dietas com grãos altamente processados que provêm grandes quantidades de MO fermentavél podem aumentar a exigência microbiana por PDR. Com a PDR limitada, diminui síntese protéica, a produção total de energia (AGV) e, em última instância, o desempenho animal, pode ser afetado (Galyean, 1996). O aumento ruminal da digestão de amido no trato total foi observado por Milton et al. (1997b) com adições de uréia em dietas de animais 
em terminação com alto teor grão, evidenciando a redução na produção de energia (AGV) com a PDR limitada.

Limitações em PDR para os microrganismos parece ser mais crítico com dietas com alta proporção de grãos altamente processados (por exemplo: floculado), dietas tipicamente americanas. O milho de alta umidade é uma exceção a esta generalização. Secrist et al. (1995) observaram efeitos adversos quando os teores de PB na dieta excederam 12\% com dietas com milho de alta umidade, provavelmente devido a grandes quantidades de $\mathrm{N}$ na forma não protéica.

Cooper et al. (2002), utilizando animais em terminação com uma dieta basicamente de milho ( $82 \%$ da MS), observaram que a exigências em PDR é dependente do processamento do grão. Os autores observaram que para milho laminado, a exigência em PDR é de 6,3\% da MS, para milho de alta umidade $10,0 \%$ da MS e para milho floculado $9,5 \%$ da MS.

Assumindo que dietas altamente fermentecíveis estão com PDR limitada para os microrganismos, o sistema de PM do NRC (1996) estima as exigências de proteína com mais precisão do que o NRC (1984), o qual utiliza o sistema fatorial, não considerando diretamente as exigências microbianas, as quais geralmente não eram satisfeitas, quando se utiliza o NRC (1984).

A produção de proteína microbiana ( $\mathrm{g}$ de $\mathrm{N}$ ) é calculada pelo produto da quantidade de substrato fermentado no rúmen (kg de carboidratos $\mathrm{CHO}$ ) multiplicada pela eficiência microbiana (g de $\mathrm{N} / \mathrm{kg}$ de $\mathrm{CHO}$ fermentado). Se for assumido que a relação típica entre $\mathrm{N}$ microbiano sintetizado e $\mathrm{MD}$ verdadeiramente fermentada no rúmen é de $25 \mathrm{~g} / \mathrm{kg}$ em dietas de animais em terminação com grãos altamente processados (Devant et al., 2001) e que o N deve ser provido totalmente na forma de PDR com uma digestibilidade verdadeira da $\mathrm{MO}$ de $60 \%$, a PB da dieta na forma de PDR deve ser de aproximadamente $9,4 \%$, ficando evidente a necessidade de altos teres de PDR nessas dietas e, considerando o milho o principal ingrediente, baixa PDR (30\% da PB), conseqüentemente o teor de PB da dieta torna-se elevado. 


\subsection{Fontes protéicas}

Os alimentos mais comuns na alimentação de bovinos de corte no Brasil são citados na Tabela 1. Pode-se observar que a proteína bacteriana e farinha de peixe são as que apresentam o melhor perfil de aminoácidos quando comparado ao do tecido animal. Ambas apresentam uma pequena deficiência de histidina. $O$ farelo de soja e o de algodão apresentam um bom perfil de AA, demonstrando apenas uma leve deficiência em metionina. $O$ milho (resíduo proteinoso do seu processamento e o grão), sorgo e a polpa cítrica são mais deficientes em lisina.

Greenwood \& Titgemeyer (2000) observaram que o primeiro aminoácido limitante em uma dieta à base de soja (casca) foi a metionina, estando de acordo com os dados apresentados para soja (farelo) na Tabela 1.

Segundo Santos (1997), a combinação de fontes ricas em proteína "bypass", na tentativa de obter uma proteína melhor balanceada em aminoácidos essenciais, tem sido sugerida por diversos nutricionistas. É preciso que fique claro que, ao combinar, por exemplo, farinha de sangue (alta em lisina e baixa em metionina) com resíduo proteinoso do processamento do milho (baixo em lisina e alto em metionina) não se obtém uma mistura alta nos dois aminoácidos, mas sim média, a qual é normalmente inferior à proteína microbiana e muitas vezes similar ao farelo de soja.

Em uma revisão sobre a utilização de proteína "bypass" para vacas em lactação, Santos (1998) observaram que a suplementação com fontes "bypass" aumentava numericamente a passagem de proteína dietética (proteína total - proteína microbiana) para o intestino pela suplementação de proteína "bypass", mas diminuía a passagem de proteína microbiana para o intestino delgado, sugerindo que a inclusão de fontes ricas em PNDR na dieta resulta em limitação de frações nitrogenadas (amônia, peptídeos e aminoácidos) para a síntese de proteína microbiana no rúmen, ficando a passagem de proteína total (proteína microbiana + proteína dietética) para o 
intestino praticamente constante, quando a proteína "bypass" substituiu o farelo de soja (Tabela 2).

Tabela 1. Avaliação química relativa das fontes protéicas em relação à proteína do tecido ${ }^{1}$.

\begin{tabular}{lcccccccccc}
\hline Fontes $^{3}$ & \multicolumn{10}{c}{ Aminoácidos $^{2}$} \\
\cline { 2 - 12 } & Met & Lis & Arg & Thr & Leu & lle & Val & His & Phe & Trp \\
\hline Bactérias & 100 & 100 & 100 & 100 & 100 & 100 & 100 & $\mathbf{8 1}$ & 100 & 100 \\
Farinha de peixe & 100 & 100 & 100 & 100 & 100 & 100 & 100 & $\mathbf{9 3}$ & 100 & 100 \\
Farelo de soja & $\mathbf{5 1}$ & 84 & 100 & 90 & 100 & 100 & 100 & 100 & 100 & 100 \\
Farelo de algodão & $\mathbf{7 3}$ & 68 & 100 & 89 & 89 & 100 & 100 & 100 & 100 & 100 \\
F. de carne e ossos & $\mathbf{4 3}$ & 88 & 100 & 65 & 81 & 86 & 91 & 58 & 86 & 100 \\
F. de sangue & $\mathbf{4 7}$ & 100 & 100 & 100 & 100 & 48 & 100 & 100 & 100 & 100 \\
F. de pena & $\mathbf{2 5}$ & 40 & 100 & 100 & 100 & 100 & 100 & 38 & 100 & 100 \\
Caroço de algodão & $\mathbf{3 2}$ & 60 & 100 & 88 & 94 & 100 & 100 & 100 & 100 & 100 \\
Resíduo P.P.M. & 100 & $\mathbf{1 9}$ & 96 & 75 & 100 & 100 & 100 & 99 & 100 & 76 \\
Milho grão moído & 57 & $\mathbf{2 6}$ & 55 & 72 & 100 & 95 & 93 & 83 & 100 & 76 \\
Sorgo grão moído & 46 & $\mathbf{3 8}$ & 100 & 84 & 100 & 100 & 100 & 92 & 100 & 100 \\
Polpa cítrica & 76 & $\mathbf{5 8}$ & 100 & 81 & 69 & 95 & 100 & 76 & 79 & 100 \\
\hline
\end{tabular}

${ }^{1}$ Cálculo: (\% de AA na proteína do alimento / \% de AA na proteína do tecido) x 100. O escore de 100 foi o máximo permitido. Concentrações de AA retiradas de Fox et al., (2000).

2 Met=metionina; Lis=lisina; Arg=arginina; Thr=treonina; Leu=Leucina; lle=isoleucina ; Val=valina; Phe=felinalanina; Trp=triptofano;

${ }^{3}$ F.=farinha; Resíduo P.P.M.=resíduo proteinoso do processamento do milho.

A suplementação de proteína "bypass" não teve efeito positivo na passagem de aminoácidos essenciais (AAE) para o intestino na maioria dos trabalhos analisados, devido à proteína microbiana apresentar qualidade superior a maioria das fontes protéicas ricas em "bypass" em termos do balanço de $A A E$, resultando em desempenho inferior com fontes ricas em PNDR quando 
comparado ao farelo de soja. Outra possível explicação seria a baixa digestibilidade das fontes de PNDR no intestino delgado (Schwab, 1994) ou que as dietas usadas como tratamento controle já estavam adequadas em PNDR (NRC, 1985).

Tabela 2. Metabolismo do farelo de soja (FS) e fontes ricas em proteína não degradável no rúmen (PNDR) para vacas em lactação.

\begin{tabular}{|c|c|c|c|}
\hline Itens $^{1}$ & FS & PNDR & FS - PNDR \\
\hline$\overline{C M S}, \mathrm{~kg} / \mathrm{d}$ & $\overline{19,4}$ & 18,8 & 0,6 \\
\hline Nitrogênio microbiano, g/d & 275,0 & 234,0 & 41,0 \\
\hline Passagem de NNANM, g/d & 217,0 & 268,0 & $-51,0$ \\
\hline NNA, g/d & 492,0 & 502,0 & $-10,0$ \\
\hline$A A E, g / d$ & 1163,0 & 1216,0 & $-53,0$ \\
\hline Lisina, $\mathrm{g} / \mathrm{d}$ & 163,0 & 172,0 & $-9,0$ \\
\hline Metionina, $\mathrm{g} / \mathrm{d}$ & 48,0 & 46,0 & 2,0 \\
\hline
\end{tabular}

Neste sentido, Klemesrud et al. (2000c), avaliando uma dieta com alta proporção de milho $(45 \%$ de resíduo fibroso do processamento do milho (wet corn gluten feed); $22,5 \%$ de milho de alta umidade; $20 \%$ de milho laminado a seco; $5 \%$ de silagem de milho; $5 \%$ de feno de alfafa; $2,5 \%$ de suplemento mineral e vitamínico; tendo $11,9 \%$ de PB), com suplementação de lisina $(0,1,2,3,4,6,8,10$ e $12 \mathrm{~g} / \mathrm{d})$ e metionina (3,6 g/d), em animais com 237 $\mathrm{kg}$ de peso vivo, observaram um aumento no ganho de peso nos animais que estavam recebendo suplementação com lisina nos primeiros 56 dias (com uma análise não linear, estimaram uma resposta máxima com 2,56 g/d de lisina com um ganho de $260 \mathrm{~g} / \mathrm{d}$ a mais que o controle), sendo este período o de maior 
exigência de proteína metabolizável e maior deposição de proteína. No período todo (161 dias) não houve diferença significativa no ganho de peso vivo (GPV), embora tenha ocorrido uma diferença numérica $(200 \mathrm{~g} / \mathrm{d})$ para o tratamento com suplementação de lisina. Não houve efeito da suplementação com metionina no ganho de peso, indicando que dietas ricas em milho não são deficientes em metionina. No entanto, a resposta no ganho sugere que a lisina seja o primeiro aminoácido limitante em novilhos terminados com dietas contendo grandes quantidades de proteína de milho, o que pode ser visto na Tabela 1.

Estudos de Klemesrud et al. (2000ac) mostraram que dietas formuladas com valores próximos de PNDR podem resultar em desempenhos completamente diferentes devido ao impacto da qualidade da fonte protéica em termos de balanço de AAE. Isso mostra claramente que o fator qualidade da fonte protéica em termos de balanço de aminoácidos é muito importante, devendo este também ser observado e não apenas o fator degradabilidade simplesmente.

Os dados de Klemesrud et al. (2000c) indicam que dietas de animais em terminação com alto teor de grão, principalmente milho, que contém proteína de baixa degradabilidade ruminal (60\% de PNDR; NRC, 1996), apresentam uma baixa possibilidade de resposta à suplementação com PNDR e/ou aminoácidos protegidos, pois o animal terá um excesso de PM, uma vez que não se pode deixar de suplementar com PDR para atender as exigência dos microrganismos ruminais (NRC, 1985; Galyean, 1996 e NRC, 1996). Respostas a suplementação com PNDR e/ou AA protegidos pode ser mais plausíveis em animais mais jovens, os quais apresentam uma maior exigência de PM.

Em animais jovens, Klemesrud et al. (2000a) avaliaram uma dieta suplementada com uréia ou com farinha de carne e ossos, sendo na última adicionado metionina protegida $(0 ; 0,45 ; 0,9 ; 1,35 ; 3,0$ e $6,0 \mathrm{~g} / \mathrm{d}) \mathrm{em}$ animais com peso inicial de $251 \mathrm{~kg}$. Em outro experimento, os autores 
utilizaram uma dieta suplementada com uréia ou resíduo proteinoso do processamento do milho (Corn gluten meal) adicionando a essa última lisina protegida $(0 ; 1 ; 2 ; 3 ; 4 ; 5 ; 6 ; 8$ e $10 \mathrm{~g} / \mathrm{d})$ em animais com peso inicial de $210 \mathrm{~kg}$. Os autores observaram que a suplementação com metionina ou lisina aumentou o GPV de novilhos alimentados com farinha de carne e ossos e resíduo proteinoso do processamento do milho, respectivamente $(P<0,10)$, em uma análise não linear para maximizar o GPV, obtendo $2,9 \mathrm{~g} / \mathrm{d}$ de metionina e $0,9 \mathrm{~g} / \mathrm{d}$ para lisina.

Zinn \& Owens (1993) observaram um melhor desempenho em animais jovens, quando adicionaram $2 \%$ de proteína de baixa degradabilidade ruminal (mistura em partes iguais de farinha de sangue, osso e pena) a uma dieta controle $(12,2 \%)$. Os autores sugerem que os aminoácidos arginina, histidina, leucina, metionina e fenilalanina podem ser os mais limitantes, em dietas baseadas em milho (floculado) para novilhos em crescimento.

Em animais jovens (rápido crescimento) a proteína microbiana não é suficiente para atender as exigências de proteína do animal, sendo necessário uma fonte de PNDR para completar a proteína microbiana. A determinação das exigências em aminoácidos e a formulação da dieta para aminoácidos podem aumentar o GPV e a eficiência de utilização da proteína (Klemesrud et al., 1997). Essa afirmação está de acordo com os dados de Zinn \& Owens (1993) e Klemesrud et al. (2000b). Entretanto, Klemesrud et al. (2000a) ressaltaram que, quando se formula dietas para ruminantes levando-se em consideração as exigências em aminoácidos metabolizáveis, deve ser considerada a quantidade não degradável e a digestibilidade de cada aminoácido.

A farinha de peixe, como demonstrado na Tabela 1, é uma boa fonte de aminoácidos essenciais, embora o seu uso seja limitado no Brasil devido a falta de uma farinha de peixe de qualidade, sendo necessário a importação, o que inviabiliza economicamente o seu uso. 
Zinn \& Shen (1998), utilizando dietas com alto teor de grão (80\% de milho floculado) com três fontes de proteína, uréia, farelo de soja e farinha de peixe em três teores (1,5, 3,0 e 4,5\% da MS) em novilhos cruzados ( $P I$ de $231 \mathrm{~kg}$ ), verificaram um aumento linear no ganho de peso vivo (GPV) com o aumento da farinha de peixe (Tabela 3), demonstrando que o aumento de AAE provindos da farinha de peixe melhorou a utilização da energia, embora não diferiu do GPV do farelo de soja, mas foi menor que o GPV da uréia. Portanto, embora a farinha de peixe tenha aumentado o fluxo de AAE para o duodeno, não proporcionou um melhor desempenho. A maior produção de proteína microbiana no tratamento com uréia e farelo de soja, proporcionou um melhor perfil de aminoácido e principalmente uma maior fermentação ruminal, aumentando o aporte energético (maior produção de ácidos graxos voláteis AGV) para o animal.

Tabela 3. Efeito da fonte nitrogenada no metabolismo e desempenho dos animais.

\begin{tabular}{lccccc}
\hline \multirow{2}{*}{ Itens $^{1}$} & & \multicolumn{3}{c}{ Farinha de peixe, \% } & \\
\cline { 3 - 5 } & Uréia & 1,5 & 3,0 & 4,0 & FS $^{2}$ \\
\hline GPV kg/d $^{\text {bc }}$ & 1,69 & 1,41 & 1,56 & 1,62 & 1,56 \\
CMS k/g $^{\text {d }}$ & 7,49 & 6,66 & 6,9 & 6,9 & 6,98 \\
CMS/ganhob $^{\text {N microbiano, g/d }}$ & 4,43 & 4,69 & 4,43 & 4,27 & 4,48 \\
& 88,6 & 61,6 & 69,4 & 73,9 & 78,0 \\
PB, \% & 11,0 & 9,7 & 10,7 & 11,6 & 11,0 \\
PNDR, \% & 4,0 & 4,5 & 5,1 & 5,9 & 4,7 \\
\hline
\end{tabular}

$1 \mathrm{GPV}=$ ganho de peso vivo; $\mathrm{CMS}=$ consumo de matéria seca; $\mathrm{N}$ =nitrogênio; $\mathrm{PB}=$ proteína bruta; PNDR=proteína não degradável no rúmen;

${ }^{2} \mathrm{FS}=$ farelo de soja;

${ }^{b}$ Efeito linear da FP, $\mathrm{P}<0,05 ;{ }^{\mathrm{c}} \mathrm{FP}$ vs uréia, $\mathrm{P}<0,10 ;{ }^{\mathrm{d}} \mathrm{FP}$ vs $\mathrm{FS}, \mathrm{P}<0,05$;

Adap. Zinn \& Shen (1998). 
Galyean (1996) citou seis consultores americanos, responsáveis pelo programa de nutrição de 3,6 milhões de cabeça por ano, e todos preconizam que proteína "bypass" pode ser importante em algumas circunstâncias, mas que as informações disponíveis são insuficientes para permitir o uso deste fator na formulação de dietas.

Com a finalidade de reduzir custo e aumentar o desempenho animal, pode-se utilizar uréia como fonte de nitrogênio no rúmen. Revendo dados da literatura, Chalupa (1968) sugeriu que a suplementação com uréia é consistentemente eficiente quando não ultrapassa $1 / 3$ do nitrogênio total ou $1 \%$ da matéria seca total da dieta. Healy et al. (1995) utilizaram dietas com milho floculado com $13 \%$ de PB e a suplementação com proteína proveniente de diferentes combinações de farelo de soja e uréia (100:0; 67:33; 33:67; 0:100). O GPV apresentou efeito quadrático, sendo o maior ganho de peso vivo com 67:33 e a maior eficiência alimentar (ganho/CMS) com a proporção de 33:67.

Devant et al. (2001) compararam dietas isonitrogenadas (13,7\%) com farelo de soja e uma mistura de resíduo proteinoso do processamento do milho (corn gluten meal) mais farinha de peixe, com e sem uréia. Quando foi adicionado uréia, a eficiência ( $\mathrm{g} / \mathrm{kg}$ de $\mathrm{MO}$ verdadeiramente digerida) e a produção de proteína microbiana aumentaram, independente das fontes de proteína verdadeira. Com isso, pode-se verificar que a utilização de uréia é benéfica, principalmente quando associada a uma fonte de proteína verdadeira, aumentando a eficiência da síntese microbiana em dietas com alto teor de concentrado.

Teores de substituição da proteína verdadeira pelo NNP (uréia) em até $40 \%$ da necessidade de proteína degradável no rúmen (PDR), aparentemente, não afetam o desempenho animal. Entretanto, o uso de suplementos com apenas NNP, como fonte de nitrogênio, não tem resultado em desempenhos consistentes (Thiago \& Silva, 2001).

Utilizando forragens de baixa qualidade, Köster et al. (2002) recomendaram inclusão de uréia no suplemento de 20 a 40\% da PDR. Bohnert 
et al. (2002) sugeriram que 40 a $80 \%$ da proteína pode estar na forma de PDR, sem que o desempenho seja prejudicado.

A suplementação de forragens de alta qualidade deve ser com uma fonte de proteína verdadeira de baixa degradabilidade preferencialmente, podendo utilizar uma pequena parcela de NNP (uréia) até um máximo de $25 \%$ da exigência de proteína degradável no rúmen (Thiago \& Silva, 2001). Isso demonstra que a quantidade da PDR proveniente da uréia vai depender da dieta (componentes protéicos, NDT) para que o desempenho não seja prejudicado.

Com base nos dados citados anteriormente, pode-se concluir que o rúmen é o principal fornecedor de proteína de alta qualidade (PBM) e, sendo assim, devemos maximizar a fermentação ruminal e produção de proteína microbiana. Para isso, deve-se: 1) fornecer um volumoso de alta qualidade para maximizar o CMS da dieta; 2) otimizar a degradabilidade ruminal do amido presente nos cereais, aumentando o suprimento de energia para os microrganismos do rúmen; 3) suprir os microrganismos ruminais com quantidades adequadas de PDR, a fim de fornecer amônia, aminoácidos e peptídeos para a síntese de proteína microbiana; 4) quando da inclusão na dieta de fontes ricas em PNDR para complementar a proteína microbiana, devese usar fontes ricas em AAE e bem balanceadas (Santos, 1997).

Sistemas que consideram a exigência de aminoácido individual e estima o fluxo duodenal, como CNCPS, é mais provável de sucesso na nutrição protéica do que sistemas que consideram apenas PDR e PNDR. Embora, seja difícil de determinar o perfil de aminoácidos da PNDR que chega ao duodeno, devido às diferenças no perfil de aminoácidos da PNDR e da proteína original do alimento, os quais geralmente não são conhecidos e a composição dos aminoácidos da proteína microbiana que também não é constante (Hoover \& Webster, 1996).

Mais estudos são necessários para estimar com maior acurácia o fluxo de aminoácidos para o duodeno, pois a exigência do animal é em 
aminoácidos essenciais absorvidos e não em proteína bruta. Estes estudos devem abordar o teor de proteína bruta da dieta, bem como as frações PDR e PNDR e também a quantidade e o perfil de aminoácidos que chegam ao duodeno, pois a nutrição protéica adequada para maximizar o ganho engloba todos estes fatores simultaneamente.

\subsection{Amiréia como fonte de proteína para ruminantes}

\subsubsection{Definição}

Amiréia (Starea em inglês), como o próprio nome já sugere, é uma associação de amido (starch) mais uréia (urea). É produzida pela mistura de grãos finamente moídos (milho, sorgo, cevada, trigo, etc.), ou qualquer fonte de amido, com uma fonte de nitrogênio não protéico, como a uréia. Em alguns casos, adiciona-se uma fonte suplementar de enxofre (Bartley \& Deyoe, 1975). O material é processado e passa por um cozimento-extrusão sob condições de umidade, temperatura e pressão, as quais causam a gelatinização do amido.

\subsubsection{Fatores que podem alterar a qualidade da amiréia}

Geralmente, não é observado o procedimento de fabricação do produto, já que várias fábricas produzem este produto com procedimentos diferentes e, muitas vezes, são titulados com o mesmo nome (amiréia ou uréia protegida), o que pode levar a uma comparação de produtos de qualidades diferentes (Bartley et al., 1973; Shiehzadeh \& Harbers, 1974 e Bartley \& Deyoe, 1975).

Dados na literatura apontam diferenças entre produtos principalmente nas concentrações de nitrogênio não protéico (Deyoe et al., 
1968; Helmer et al., 1970b; Shiehzadeh \& Harbers, 1974; Barr et al., 1975; Lee et al., 1975; Stiles et al., 1975b; Wright \& Totusek, 1975; Maia et al., 1987; Feitosa et al., 2000 e Ezequiel et al., 2000), encontrando valores de equivalente protéico de 23 a $150 \%$. As fontes de amido podem alterar a qualidade do produto (Shiehzadeh \& Harbers, 1974; Barr et al., 1975; Stiles et al., 1975b e Teixeira et al., 1999), como o grau de gelatinização do amido (Shiehzadeh \& Harbers, 1974; Barr et al., 1975 e Stiles et al., 1975a), a forma física da amiréia (Teixeira et al., 1999; Carmo et al., 1999; Feitosa et al., 2000 e Ezequiel et al., 2000) e a relação enxofre:nitrogênio (Thompson et al., 1972).

\subsubsection{Amiréia X Uréia}

Os microrganismos ruminais são capazes de sintetizar proteína microbiana a partir de amônia e esqueleto carbônico, sendo o nitrogênio não protéico uma das fontes de amônia para os microrganismos. Neste contexto, se insere a amiréia e a uréia como fontes de nitrogênio não protéico. Uma fonte de nitrogênio não protéico tem a vantagem de geralmente ser mais barata que uma fonte de proteína verdadeira na mesma quantidade de nitrogênio.

A fonte de nitrogênio não protéico mais utilizada (uréia) apresenta uma rápida liberação de amônia no rúmen, acima da capacidade dos microrganismos em utilizá-la, sendo parte absorvida pela parede ruminal, que será convertida em uréia. Mesmo ocorrendo um aproveitamento (reciclagem) da uréia pelo rúmen via parede ruminal ou saliva, a transformação de amônia em uréia no fígado resulta em gasto de energia, o qual pode ser evitado caso toda amônia seja utilizada pelos microrganismos ruminais. Uma parte do nitrogênio absorvido que não é reciclado, será excretado através da urina pelo animal.

O fígado gasta três ATP para converter (ciclo da uréia) uma molécula de amônia em uréia. Em outros tecidos (rins, músculo, cérebro), o ácido glutâmico reage com a amônia para formar a glutamina com gasto de um 
ATP. A fonte imediata de ácido glutâmico e o alfa-ceto-glutamato esta conversão tem um gasto de um ATP, sendo este um composto intermediário do ciclo do ácido cítrico, o qual é a chave da geração de energia para o animal. Sendo alta a demanda de alfa-ceto-glutamato o ciclo do ácido cítrico pode ser comprometido, prejudicando o status energético do animal. A excreção de um grama de $\mathrm{N}$ na urina gasta $5,45 \mathrm{kcal}$ (Blaxter, 1962).

Zinn \& Owens (1993) sugeriram que o excesso de proteína "bypass" pode promover uma demanda adicional de Arginina para a desintoxicação de amônia, podendo limitar o crescimento e o desempenho animal.

A suplementação com NNP, além de fornecer amônia para síntese de proteína microbiana (principalmente em bactérias, mas também de maneira mais reduzida em protozoários e fungos) e a menor custo ( $\mathrm{kg} \mathrm{de} \mathrm{N}$ ), apresenta outras vantagens: 1) cria uma ação tamponante no rúmen, de modo a manter $\mathrm{opH}$ em uma faixa mais adequada para a digestão da celulose; 2) altera o hábito alimentar no sentido de refeições mais freqüentes, resultando em um possível incremento na eficiência energética da dieta (Huber, 1994).

Uma fonte de nitrogênio não protéico com uma liberação lenta de amônia teria vantagens de aumentar a disponibilidade de amônia para síntese microbiana e reduzir problemas com toxidez. Com base nestes conhecimentos, no final da década de 60 , pesquisadores americanos iniciaram pesquisas com amiréia. No Brasil, há trabalhos no início da década de 90 até os dias de hoje. A seguir, serão apresentados dados de pesquisas onde foi comparado amiréia com uréia. 


\subsubsection{Na concentração de amônia ruminal e síntese de proteína microbiana}

Helmer et al. (1970b) realizaram três experimentos in vitro com sete comparações entre amiréias com várias concentrações protéicas e a uréia. Estes autores observaram que a concentração ruminal de amônia foi menor para o tratamento com amiréia nas sete comparações, com uréia mais milho moído. Entretanto, quando utilizaram uréia mais milho extrusado (submetido ao mesmo procedimento utilizado na fabricação da amiréia) nas sete comparações não verificaram diferenças em seis e, em apenas uma, a amiréia apresentou valores menores.

Os mesmos autores realizaram três comparações (in vitro) entre uréia mais milho extrusado versus uréia mais milho moído e nas três, a uréia mais milho extrusado apresentou valores menores na concentração de amônia ruminal. As concentrações de nitrogênio bacteriano apresentaram basicamente os mesmos resultados obtidos nas concentrações de amônia ruminal, sendo superior para amiréia quando comparado com uréia mais milho moído e igual quando se utilizou uréia mais milho extrusado. Esta última, por sua vez, apresentou valores superiores aos da uréia mais milho moído.

Helmer et al. (1970b), avaliando a produção de proteína microbiana (in vitro) entre amiréia e uréia, observaram que a amiréia apresentou valores superiores nas duas avaliações quando comparada a uréia mais milho moído e não diferiu nas duas comparações com uréia mais milho extrusado. A uréia mais milho extrusado produziu mais proteína microbiana que a mistura uréia mais milho moído, ou seja, estes resultados foram semelhantes aos de amônia ruminal e concentração de nitrogênio bacteriano.

Em um trabalho de pesquisa in vitro, Barr et al. (1975) observaram que a síntese de proteína microbiana no tratamento com amiréia (45S, milho) não diferiu da mistura uréia mais milho extrusado e ambos foram superiores à mistura uréia mais milho moído. Utilizando amiréia (70S, sorgo) 
com três procedimentos de fabricação, todos proporcionaram uma maior síntese de proteína microbiana comparado à mistura uréia mais sorgo moído, mas não utilizaram sorgo extrusado nesta comparação.

Utilizando novilhos em terminação, Stiles et al. (1975a) observaram (Exp. 1) uma menor concentração de amônia ruminal no tratamento com amiréia quando comparada a uma mistura uréia mais sorgo moído grosso (quebrado), após sete dias de alimentação. A amiréia proporcionou valores que não diferiram da mistura uréia mais sorgo moído fino ou sorgo extrusado. Já em outra avaliação (Exp. 2), a concentração de amônia não diferiu entre amiréia e sorgo moído grosso (quebrado), mas o tratamento com amiréia produziu mais proteína bacteriana.

Os dados apresentados acima estão de acordo Smith (1979), o qual salientou a importância do fornecimento controlado de uma fonte de energia para estimular a síntese eficiente de proteína microbiana, afirmando que a manipulação adequada da fonte de energia poderia incrementar mais 0 uso de NNP do que a modificação do padrão de liberação de amônia.

Utilizando a raspa de mandioca como fonte de amido para produzir amiréia com quatro teores de equivalente protéico (24; 29; 39 e 44\%), Maia et al. (1987) observaram 2,5 vezes mais produção de proteína microbiana in vitro, quando se utilizou amiréia comparada com uma mistura de uréia mais raspa de mandioca integral na mesma equivalência protéica, porém, não apresentaram análise estatística no trabalho.

Thompson et al. (1972), comparando fontes nitrogenadas para novilhos em crescimento, com silagem de milho ad libitum e $0,45 \mathrm{~kg}$.animal ${ }^{-1} \cdot \mathrm{d}^{-1}$ de suplemento com $45 \%$ de PB, observaram que a amiréia promoveu uma concentração de amônia ruminal igual à uréia até três horas após a alimentação. A partir deste horário, a amiréia apresentou valores menores. Contrariando estes dados, Schmidt et al. (1973), utilizando novilhos em terminação com uma dieta basicamente concentrada e restrita $(90 \%$ do consumo ad libitum), não observaram diferenças na concentração ruminal até 
3,5 horas após alimentação e, posteriormente a este horário, a amiréia permaneceu com valores superiores àuréia.

Por outro lado, Shiehzadeh \& Harbers (1974), utilizando borregos (peso inicial de $35 \mathrm{~kg}$ ) para avaliar o uso de amiréia (44 e 70\% de equivalente protéico) e uma mistura de mesmo equivalente protéico de uréia mais sorgo moído, não encontraram diferenças na concentração de amônia ruminal.

\subsubsection{Amiréia e processamento de grãos}

A união do grão de cereal e uréia em condições apropriadas de calor, pressão e umidade, por um determinado tempo (que é utilizado no processo de fabricação da amiréia), resulta em uma combinação da uréia com o grânulo de amido. Neste processo, o grão é gelatinizado e com isso, aumenta sua acessibilidade ̀̀s enzimas do conteúdo ruminal, aumentando sua degradação ruminal e tornando-a mais próxima da liberação de amônia pela uréia.

Com o aumento do grau de gelatinização do milho, observa-se um aumento na proporção de ácido propiônico e uma redução na proporção de ácido acético, sendo a produção total de ácidos graxos voláteis totais aumentada e a concentração de amônia ruminal reduzida (Wilson \& Woods, 1966 e 1967), podendo promover uma maior síntese de proteína microbiana, tanto com amiréia (amido gelatinizado) como com a uréia mais grão gelatinizado (Helmer et al., 1970b e Barr et al., 1975).

Alguns experimentos têm demonstrado que não há diferença na concentração ruminal de amônia quando se compara amiréia com uma mistura de uréia mais grão extrusado (gelatinizado) (Helmer et al., 1970b e Stiles, et al., 1975a). Grãos que passam pelo processo de floculação, aumentando sua taxa de degradação, diminui a concentração ruminal de amônia, tanto para sorgo (Simas, 1995) ou milho (Mendes Junior, 1999). Neste sentido, Bartley et d. 
(1976) observaram uma correlação significativa $(r=-0,22)$ entre grau de gelatinização do amido e amônia ruminal.

Roffler \& Satter (1975) observaram que a concentração ruminal de amônia é função $\left(\mathrm{R}^{2}=0,92\right)$ do teor de NDT e PB da dieta: $\mathrm{N}-\mathrm{NH}_{3}, \mathrm{mg} / \mathrm{dL}=$ $38,73-3,04 x \mathrm{~PB}+0,171 \times \mathrm{XP}^{2}-0,49 x N D T+0,0024 \times \mathrm{NDT}^{2}$. O processamento do grão (extrusão) aumenta o seu NDT (NRC, 2001) e conseqüentemente, reduz a concentração de amônia no rúmen.

Tudo isso pode ser um indicativo de que a menor concentração de amônia ruminal e uma maior síntese de proteína microbiana (in vitro), quando se utiliza amiréia, seria devido ao processamento do grão (aumento da fermentação ruminal do amido no rúmen) e não, devido à redução da intensidade de liberação de amônia proveniente da uréia. Outro aspecto que ajuda esta teoria são os melhores resultados com amiréia com menor proporção de uréia (Deyoe et al., 1968 e Shiehzadeh \& Harbers, 1974). Portanto, são necessários mais estudos (in vivo) para esclarecer estas dúvidas, porém, não foram encontrados trabalhos de produção (leite ou carne) comparando amiréia e uréia mais grão extrusado.

\subsection{Processamento físico da amiréia}

Teixeira et al. (1999) utilizaram várias formas físicas da amiréia (integral, quebrada e moída) e fontes de amido (milho e raspa de mandioca), contendo $45 \%$ de equivalente protéico e observaram que a moagem da amiréia $45 S$ formada pelo amido do milho, quando comparada com a forma quebrada e inteira (pellet de aproximadamente $1 \mathrm{~cm}$ de diâmetro), promoveu um aumento da degradabilidade potencial e na taxa de degradação da matéria seca. Quando a fonte de amido foi a raspa de mandioca, observaram um aumento somente para a degradabilidade potencial da materia seca. Independente do processamento físico utilizado, a degradabilidade efetiva da matéria seca 
apresentou valores maiores para amiréia formada com raspa de mandioca. Por outro lado, o processamento físico (inteiro, quebrado e moído) não afetou a degradabilidade efetiva da proteína bruta da amiréia.

Observando os dados demonstrados por Teixeira et al. (1999), pode-se verificar que $80 \%$ da proteína ou equivalente protéico da amiréia é proveniente da uréia. Considerando a fração solúvel da proteína do milho de $8 \%$ e $100 \%$ a da uréia (NRC, 1996), obtém-se $82 \%$ do nitrogênio total da amiréia na forma solúvel. A média da fração solúvel das três formas físicas da amiréia formada por milho foi de $81,5 \%$, valor muito próximo da fração solúvel estimada (82\%), demonstrando que a amiréia $45 S$ não diminuiu a taxa de liberação de nitrogênio (amônia), sendo esta similar a uma mistura milho mais uréia.

Feitosa et al. (2000), avaliando a degradabilidade da matéria seca e proteína bruta ( $\mathrm{N}$ total) de quatro amiréias (amiréia moída com $20 \%$ de uréia, amiréia na forma de pellet com 20, 25 e 30\% de uréia), observaram que a amiréia moída ( $20 \%$ de uréia), quando comparada com a amiréia na forma de pellet apresentou uma maior degradabilidade, sendo que a amiréia moída apresentou $23 \%$ a mais de proteína bruta prontamente solúvel do que na forma de pellet, com o mesmo teor de uréia. Considerando a fração solúvel da proteína do milho de $8 \%$ e $100 \%$ a da uréia (NRC, 1996), obtém-se $89 \%$ do nitrogênio total da amiréia na forma solúvel. A amiréia moída apresentou $93 \%$, valor muito próximo do estimado (89\%), indicando que a amiréia na forma moída não diminuiu a taxa de liberação de nitrogênio.

A amiréia (45S) na forma de pellet proporciona uma fração solúvel de aproximadamente $10 \%$ menor, quando comparada com a forma moída, produzida com milho ou raspa de mandioca (Teixeira et al., 1999). A amiréia (63\% de equivalente protéico) com um maior teor de uréia $(20 \%)$, quando moída, apresenta aproximadamente $23 \%$ mais nitrogênio solúvel, quando comparada àpeletizada (Feitosa et al., 2000). 
Estudando a degradabilidade da amiréia moída a $2 \mathrm{~mm}$, Silva (1999) observou que a degradabilidade efetiva $(5,0 \% / \mathrm{h})$ foi apenas sete unidades percentuais superior quando comparada à fração solúvel ("a") da amiréia ( 84,7 e $77,2 \%$, respectivamente), demonstrando que a quase totalidade do nitrogênio da amiréia está na forma solúvel.

Carmo et al. (1999), avaliando a degradabilidade da proteína bruta ( $\mathrm{N}$ total) da amiréia contendo $25 \%$ de uréia com diferentes granulometrias (pellet, quebrados ao meio e quebrados em quatro partes iguais), observaram valores de $86,8 \%$ e 58,0\% para a fração solúvel ("a") para a forma quebrada e pellet, respectivamente. A fração "b" do nitrogênio do pellet quebrado em quatro e do pellet inteiro foram 8,7 e $37,0 \%$, respectivamente; mostrando que o $\mathrm{N}$ na amiréia quebrada em quatro foi mais solúvel que degradável, sugerindo que amiréia quebrada em quatro teve o $\mathrm{N}$ totalmente solúvel em um tempo muito curto e a forma inteira liberou o $\mathrm{N}$ mais gradativamente. $\mathrm{O}$ pellet quebrado em dois apresentou comportamento intermediário entre o pellet inteiro e aquele quebrado em quatro partes. Os autores concluíram que a amiréia deve ser fornecida sem qualquer processo de quebra ou moagem, pois se consegue um melhor efeito da liberação modulada da amiréia.

No mesmo sentido, Ezequiel et al. (2000), utilizando amiréia com diferentes teores de uréia (20, 25 e 30\%), nas formas moídas e pellet, verificaram que a solubilidade protéica do pellet foi diminuída em $32,5 \%(93,14$ e 62,85\%) em relação a forma moída. No entanto, Valadares Filho et al. (1990) observaram uma menor fração solúvel da amiréia moída quando comparada a uma mistura de uréia mais milho moído sem extrusão $(0,619$ e 0,884 , respectivamente).

Estes dados levam a concluir que o processamento físico da amiréia (quebra ou moagem) altera a fração solúvel da proteína (liberação de nitrogênio), tornando a fração solúvel da proteína da amiréia muito próxima de uma mistura de uréia mais milho sem extrusão. Isso leva a hipótese de que a moagem de $2 \mathrm{~mm}$, utilizada nos alimentos avaliados no procedimento in situ, 
poderá aumentar a fração solúvel ("a") da amiréia e, mesmo o procedimento de lavagem extensiva, manual em água corrente ou em máquinas, poderá destruir o grânulo de amido que envolve a uréia, o que superestimaria a fração solúvel, principalmente a fração nitrogenada.

Alguns dos benefícios sugeridos para amiréia é que ela apresenta uma liberação lenta de nitrogênio no rúmen. Como visto anteriormente, isto não ocorre se a amiréia estiver na forma moída ou de pellet quebrado e esta alta solubilidade pode levar o animal a uma intoxicação com amônia, dependendo da quantidade de amiréia na dieta. A amiréia na forma de pellet diminui um pouco a solubilidade do nitrogênio, mas esta ainda é bem elevada quando comparada a fontes de proteína verdadeira, sendo necessário trabalhos de desempenho para verificar os possíveis benefícios desta técnica. Além disso, a amiréia na forma de pellet pode apresentar segregação nas misturas, dificultando a sua utilização.

\subsubsection{Na toxidez por amônia}

Uma das vantagens apontada pela indústria da amiréia é ser menos tóxica que misturas de grão mais uréia. Bartley et al., citados por Bartley \& Deyoe (1975), conduziram estudos toxicológicos com amiréia e outras fontes de nitrogênio não protéico em aproximadamente 300 animais. Todos os animais utilizados não estavam recebendo uréia por sete dias e foram submetidos a jejum por 15 horas antes do início dos testes. Os animais recebiam a uréia via cânula ruminal numa proporção de $50 \mathrm{~g}$ de uréia (matéria seca) por $100 \mathrm{~kg}$ de peso vivo. Foram colhidas amostras de sangue na jugular antes e em intervalos de 30 minutos após o recebimento da uréia e observaram que a concentração de amônia no sangue e o pH ruminal foram altamente correlacionados ( $r=$ 0,$976 ; r=0,916$, respectivamente) com a toxidez e o $N$-uréia no plasma não foi correlacionado $(r=-0,19)$ com a toxidez segundo Bartley et al. (1976). Quando 
o pH ruminal excedeu 7,6, os autores verificaram a ocorrência de toxidez clínica em mais de $50 \%$ dos animais. Para a surpresa dos pesquisadores, a concentração de amônia ruminal não foi relacionada com a toxidez $(r=-0,064$ baseado em 244 tentativas de toxidez).

É aparente que o animal pode tolerar uma concentração alta de amônia no rúmen proveniente da uréia se o $\mathrm{pH}$ ruminal não ultrapassar 7,2 . Isto é explicado devido à absorção de amônia ser aumentada notadamente quando $\mathrm{pH}$ ruminal excede 7,2. O pH médio em 125 testes onde aconteceu toxidez foi de 7,4 (Bartley et al., citados por Bartley \& Deyoe, 1975). Zinn (1994) comentou que no $\mathrm{pH}$ ruminal de 6,0 somente $0,16 \%$ da amônia está na forma não ionizada (absorvível), sugerindo um tratamento com 2,5 a 5 litros de ácido acético a $5 \%$ via oral para animais intoxicados.

Neste experimento (Bartley et al., citados por Bartley \& Deyoe, 1975), misturas de grãos moídos mais uréia e amiréia pouco processada eram freqüentemente tóxicas, enquanto que a amiréia de alta qualidade (amido com alto grau de gelatinização) não era tóxica. Houve uma relação inversa, porém não perfeita, entre grau de processamento do amido e toxidez.

$O$ amido mais processado (danificado) também resulta em um produto mais fermentescível e reduz o pH ruminal e a velocidade de absorção de amônia, bem como a concentração de amônia ruminal devido a maior síntese de proteína microbiana, ou seja, são os efeitos citados acima que reduzem a toxidez por amônia proveniente da amiréia e não, devido à sua suposta liberação mais lenta de amônia.

A estrutura da uréia pode influenciar na toxidez, pois quando cristalina, o material é mais tóxico. Uréia em estrutura cristalina nativa é provavelmente mais prontamente disponível ao ataque pela uréase bacteriana do que outras estruturas (amorfas) (Behnke et al., citados por Bartley \& Deyoe, 1975). Para que se tenha uma uréia em estrutura não cristalina (ao microscópio eletrônico), são necessários dois fatores: 1) uma menor quantidade de uréia na amiréia e 2) o amido tem que apresentar um alto grau de gelatinização 
(processamento) para envolver a uréia. Estas duas condições são almejadas em uma amiréia de alta qualidade, mas indiretamente está se aumentando grãos altamente fermentescíveis para o animal.

A redução da taxa de formação de amônia por meios de oferta em quantidades pequenas e freqüentes, modificação química ou inibição da atividade da uréase, podem promover uma redução no perigo de toxidez por amônia. Entretanto, não há melhoria na utilização do nitrogênio. A maioria das tentativas que foram feitas para demonstrar tal melhoria, na realidade, falharam. Parece mais sensato controlar toxidez por uréia e assegurar uma disponibilidade adequada conjuntamente com a energia (sincronismo) do que substituir a uréia por outra fonte mais cara (Smith, citado por Bartley \& Deyoe, 1975 e Owens \& Zinn, 1988).

Mizwicki et al. (1980), avaliando o efeito da liberação lenta de amônia (slowrelease), concluíram que ainda precisa ser provada a teoria em que a liberação lenta de amônia promove benefícios metabólicos, sendo a prevenção da toxidez a única vantagem de compostos com taxas de liberação lenta de amônia. O mesmo foi observado por Owens et al. (1980) e Tedeschi (2001).

Outro fator a ser considerado na toxidez de animais por amônia é a adaptação dos animais. Segundo Stiles et al. (1975a) novilhos não adaptados apresentavam sintomas de toxidez por uréia quando estavam recebendo $60 \mathrm{~g}$ de uréia por $100 \mathrm{~kg}$ de peso vivo e quando adaptados, necessitavam de $108 \mathrm{~g}$ por $100 \mathrm{~kg}$ de peso vivo. considerando um animal de $350 \mathrm{~kg}$ de peso vivo consumindo $2 \%$ do peso vivo $(7,0 \mathrm{~kg} \mathrm{MS} / \mathrm{d})$ e recebendo $100 \mathrm{~g}$ de uréia por 100 $\mathrm{kg}$ peso vivo $(350 \mathrm{~g} / \mathrm{d})$, teria aproximadamente $5 \%$ de uréia na ração total e 14\% de proteína bruta na dieta provindos só da uréia, o que já estaria acima das exigências de animais em crescimento ou terminação. Como pode ser visto, são raras as situações onde necessitaria utilizar esta quantidade de uréia (100 g de uréia por $100 \mathrm{~kg}$ peso vivo). Para animais adaptados, a quantidade de uréia máxima necessária na ração total está longe de dosagens tóxicas. 


\subsubsection{Na retenção de nitrogênio}

Shiehzadeh \& Harbers (1974), utilizando borregos em terminação, com três fontes nitrogenadas: amiréia (sorgo como fonte de amido) com dois teores de equivalente protéico (40 e $70 \%$ ) e uma mistura de uréia e sorgo moído, observaram uma maior retenção de nitrogênio nos tratamentos com amiréia. Entretanto, Silva et al. (1994) observaram uma maior retenção de nitrogênio para o tratamento com uréia quando comparado a amiréia (50S), também utilizando borregos. Salman et al. (1997) não observaram diferenças no balanço de nitrogênio entre uréia e amiréia (30S) quando alimentaram borregos. Em vacas lactantes, Teller et al. (1982) e Teller \& Godeau (1986) não observaram diferenças no balanço de nitrogênio. Entretanto, Teller \& Godeau (1986) também observaram uma maior quantidade de nitrogênio excretada no leite no tratamento com amiréia comparado a uréia.

Os dados supra citados não seguem uma mesma lógica (falta consistência), não permitindo uma conclusão do assunto. Faltam trabalhos que avaliem o balaço de nitrogênio em bovinos de corte, bem como a necessidade de determinações da síntese de proteína microbiana, pois a amiréia apresenta uma fonte de amido com alta taxa de degradação e uma suposta liberação mais lenta de amônia. Com isso, é de se esperar uma maior síntese de proteína microbiana, a qual apresenta alto valor biológico, portanto, uma maior retenção de nitrogênio.

Embora os poucos dados não sejam conclusivos, estes indicam que os efeitos da amiréia não estão sendo suficientes para aumentar a retenção de nitrogênio. Outro fator a considerar, é o procedimento de fabricação da amiréia. Shiehzadeh \& Harbers (1974) observaram uma maior retenção de nitrogênio em amiréia com fonte de amido (sorgo ou batata) submetidos a um maior grau de gelatinização. 


\subsubsection{No consumo de matéria seca e desempenho}

Não foram observadas alterações no consumo de matéria seca, ganho de peso vivo e conversão alimentar em seis experimentos totalizando oito comparações entre amiréia e uréia (Thompson et al., 1972; Schmidt et al., 1973; Seixas et al., 1999 e Teixeira et al., 2000) em novilhos em crescimento ou acabamento. É importante salientar que, dentro destas oito comparações, em apenas duas os animais estavam submetidos a dietas que proporcionaram ganhos de peso diário menores que $1,0 \mathrm{~kg}$.animal ${ }^{-1} \cdot \mathrm{d}^{-1}$. O mesmo foi observado no ganho de peso diário em animais sob pastejo segundo Teixeira et al., (1998): 264,$9 ; 244,1$ g.animal ${ }^{-1} \cdot d^{-1}$ e Oliveira (2001a): 435,0; 419,0 g.animall ${ }^{-1} \cdot d^{-1}$, quando utilizaram suplemento com uréia ou amiréia, respectivamente.

Revendo dez anos de pesquisa com amiréia, Bartley \& Deyoe (1975) sumarizaram diversos trabalhos totalizando 12 comparações de ganho de peso diário em novilhos em terminação, recebendo uréia ou amiréia. Os autores observaram que, em nenhuma das avaliações ocorreram diferenças, sendo que as médias de todas as comparações foram iguais $(1,25 \mathrm{~kg}$.animal $\left.{ }^{1} . d^{-1}\right)$ para uréia e amiréia. Teixeira et al. (1999) não verificaram alterações entre amiréia e uréia na biometria do trato gastrointestinal e características de carcaças em bovinos em crescimento.

Em dois trabalhos, Shiehzadeh \& Harbers, (1974) e Ezequiel et al., (2001a) não observaram diferenças no consumo de matéria seca e no ganho de peso vivo em borregos alimentados com uréia ou amiréia. Silva et al. (1994) e Salman et al. (1997) em três comparações, avaliaram apenas o consumo de matéria seca e também não observaram alterações quando alimentaram borregos com uréia ou amiréia.

Jones et al. (1975), Teller et al. (1982), Teller \& Godeau (1986) e Carmo (2001) não observaram alterações na produção de leite corrigida ou não para o teor de gordura em vacas lactantes alimentadas com uréia ou amiréia. Roman-Ponce et al. (1975) observaram uma produção de leite superior para 
amiréia, mas a produção de leite corrigida para gordura não foi alterada, embora, tivessem observado uma redução no consumo de matéria seca no tratamento com uréia, talvez devido à alta quantidade de uréia na ração total, que era de $1,7 \%$.

Stiles et al., (1975b) também observaram um maior consumo de concentrado em vacas lactantes recebendo amiréia quando comparado a uréia. Isso ocorreu possivelmente devido ao fornecimento do concentrado ser separado do volumoso (limitado em 1\% do PV) e não em uma mistura total.

Helmer et al. (1970a) observaram uma maior produção de leite quando utilizaram amiréia e uma mesma produção de gordura entre uréia e amiréia. No entanto, neste experimento, a quantidade de volumoso era limitada (o qual não diferiu entre os tratamentos), mas o consumo de concentrado foi bem menor para o tratamento com uréia $\left(12,8\right.$ e $7,6 \mathrm{~kg}$.animal $\left.{ }^{-1} \cdot \mathrm{d}^{-1}\right)$. Isto ocorreu provavelmente devido ao alto teor de uréia no concentrado (próximo de $2,8 \%$ ) associado ao baixo teor de equivalente protéico da amiréia utilizada (23\%), demonstrando que havia muito grão processado na dieta proveniente da amiréia. Confirmando isto, Deyoe et al. (1968) observaram que a amiréia com 24 e $34 \%$ de equivalente protéico são superiores a amiréia $44 \%$. No mesmo sentido, Helmer et al. (1970b) concluíram que teores de 34 e $39 \%$ de equivalente protéico foram mais eficientes que $44 \%$. Já em cabras lactantes, Fernandes et al. (2001) não verificaram diferenças no consumo de matéria seca e produção de leite com uréia ou amiréia (com 150\% de equivalente protéico).

Totalizando todas as 22 comparações entre uréia e amiréia em bovinos em crescimento ou terminação, pode-se observar que dificilmente a amiréia poderá apresentar uma melhora no desempenho (ganho diário) dos animais quando substitui a uréia.

Os primeiros trabalhos in vitro apontavam vantagens para amiréia, como menor concentração de amônia ruminal, daí uma menor toxidez; maior concentração de nitrogênio bacteriano e maior síntese de proteína microbiana; no entanto, quando foi testado diretamente nos animais (in vivo), 
estes efeitos não promoveram um melhor desempenho nos animais. A técnica in vitro, muito utilizada e adequada em algumas situações, exige precauções ao extrapolar seus resultados para o desempenho dos animais.

Isto poderia indicar que estudos de digestão in vitro com dietas contendo nitrogênio de alta solubilidade ou degradabilidade deveriam ser associados ao conhecimento da taxa de passagem e, conseqüentemente, do tempo de permanência no rúmen que as mesmas proporcionam. Vale lembrar que o ritmo de degradação varia com o tipo de alimento e, nas condições in vivo, grande parte do nitrogênio amoniacal é absorvido pela parede ruminal, ficando indisponível para os microrganismos, pelo menos temporariamente, a par do processo de reciclagem de nitrogênio. Nas condições in vitro, poder-seia estar otimizando a disponibilidade de nitrogênio amoniacal durante grande parte do período de fermentação, o que maximizaria a digestão ruminal (Ezequiel et al., 2001b).

\subsubsection{Amiréia X Proteína verdadeira}

\subsubsection{1 $\mathrm{Na}$ concentração de amônia ruminal e síntese de proteína microbiana}

Edwards \& Bartlley (1979) realizaram dois experimentos in vitro, comparando farelo de soja e amiréia em dietas com cinco teores de proteína (17; 20; $23 ; 27$ e $30 \%$ ), sendo que no segundo experimento, foi substituído o sorgo moído por sorgo extrusado (cozido), na mesma quantidade que foi fornecido via amiréia, e também foi retirado o tratamento com $30 \%$ de proteína. No primeiro experimento, nas cinco comparações, a amiréia apresentou valores na concentração ruminal de amônia superiores ao farelo de soja e em quatro destas, ocorreu um aumento na síntese de proteína microbiana no tratamento com amiréia e somente a com $17 \%$ não diferiu. No segundo experimento, nas 
quatro comparações (teores), a concentração de amônia ruminal foi superior para a amiréia e em duas destas (23 e 27\%), os autores observaram uma maior síntese de proteína microbiana no tratamento com amiréia.

Observando a média da concentração ruminal de amônia no primeiro experimento e tirando o ratamento de $30 \%$ que não estava presente no segundo experimento, o primeiro apresenta: 37,0 e 10,2 mg/100 ml e no segundo: 36,1 e $4,1 \mathrm{mg} / 100 \mathrm{ml}$ para amiréia e farelo de soja, respectivamente. Observa-se que, embora tenha ocorrido uma redução de 2,4\% na concentração de amônia na dieta com amiréia, no tratamento com farelo de soja esta redução foi de 59,8\%, quando foi utilizado sorgo extrusado (Exp. 2). A síntese de proteína microbiana aumentou $35,6 \%$ e $51,9 \%$ para amiréia e farelo de soja, respectivamente, quando foi utilizado sorgo extrusado (Exp. 2).

Foi demonstrado que, embora tenha aumentado a síntese de proteína microbiana da dieta com amiréia no segundo experimento, o aumento no tratamento com farelo de soja foi muito superior, bem como a redução na concentração de amônia ruminal, quando utilizaram sorgo extrusado, indicando que o processamento do amido por si só reduz a concentração de amônia ruminal e aumenta a síntese de proteína microbiana.

Helmer et al. (1970b) não observaram diferenças na produção de proteína microbiana, quando compararam amiréia e farelo de soja em dois experimentos de digestibilidade in vitro, com os ingredientes puros (Exp. 1) ou adicionados de milho até atingir $16 \%$ de proteína.

Os trabalhos revisados têm demonstrado que nas primeiras horas após alimentação, a concentração de amônia ruminal (in vivo) é superior para as dietas com amiréia quando comparadas às com farelo de soja em novilhos. Thompson et al. (1972) observaram concentrações de amônia ruminal na dieta com amiréia superior até 3,0 horas e Schmidt et al. (1973) até 5,5 horas; em borregos, Shiehzadeh \& Harbers (1974) observaram até 1,0 hora para amiréia com sorgo de alto grau de gelatinização, até 3,0 horas para sorgo de baixo grau de gelatinização e batata de alto grau de gelatinização, e até 4,0 horas para 
batata de baixo grau de gelatinização; em vacas lactantes, Roman-Ponce et al. (1975) observaram até 2 horas (último horário avaliado) e Carmo (2001) observou que de 4 a 6 horas após alimentação, a concentração de amônia ruminal foi superior para amiréia comparado ao farelo de soja.

\subsubsection{No consumo de matéria seca e desempenho}

O consumo de matéria seca não foi alterado entre animais alimentados com amiréia ou farelo de soja em três experimentos, totalizando quatro comparações em novilhos (Thompson et al., 1972; Schmidt et al., 1973 e Teixeira et al., 2000), em dois experimentos com três comparações em borregos (Silva et al., 1994 e Shiehzadeh \& Harbers, 1974), em três experimentos perfazendo quatro comparações em vacas lactantes (Helmer et al., 1970a; Randel et al., 1975 e Roman-Ponce et al., 1975) e em um experimento com cabras lactantes (Fernandes et al., 2001). Todas as 12 comparações com animais de diferentes finalidades e categorias, não foram observadas diferenças no consumo de matéria seca, entre amiréia e farelo de soja.

Nos trabalhos revisados, apenas um (Morril \& Dayton, 1974) apresentou diferença no consumo de matéria seca em bezerras (de sete a 12 semanas de idade), sendo o consumo superior nos tratamentos com farelo de soja, tanto na dieta com 15 ou $19 \%$ de proteína bruta, sendo o mesmo observado para o ganho de peso vivo. O resultado deste experimento demonstra que animais muito jovens (sete semanas) apresentam uma baixa capacidade de utilização de alguns nutrientes (ex. NNP), associado a uma maior exigência de proteína metabolizável, favorecendo os tratamentos com proteína verdadeira de alta qualidade (farelo de soja).

Os ganhos de peso vivo em bovinos não foram alterados em três comparações (Thompson et al., 1972 e Teixeira et al., 2000) entre amiréia e 
farelo de soja e em apenas uma, foi superior para o farelo de soja (Schmidt et al., 1973). Shiehzadeh \& Harbers (1974), utilizando borregos, não observaram diferenças entre amiréia e farelo de soja.

Em uma revisão sobre amiréia, Bartley \& Deyoe (1975), sumarizaram diversos trabalhos totalizando 12 comparações de ganho de peso diário em novilhos em terminação suplementados com amiréia ou proteína verdadeira, não observaram alterações em nenhuma das avaliações, sendo que as médias de todas as comparações sumarizadas foram 1,27 e 1,28 kg.animal' ${ }^{1} . d^{-1}$ para amiréia e proteína verdadeira, respectivamente.

Trabalhos que compararam amiréia e farelo de algodão demonstraram resultados semelhantes aos com farelo de soja, não apresentando diferenças no consumo de matéria seca ou ganho de peso vivo em novilhos (Seixas et al., 1999) ou em borregos (Salman et al., 1997 e Ezequiel et al., 2001a).

Com isso, pode-se verificar que em 16 comparações com bovinos e três com borregos, não houve diferenças no ganho de peso e em apenas duas (Schmidt et al., 1973 e Morril \& Dayton, 1974) a fonte de proteína verdadeira foi superior a amiréia. Isso mostra que a amiréia proporciona desempenhos semelhantes à proteína verdadeira, ou ligeiramente inferior e o seu uso será dependente da dieta (ex. degradabilidade da proteína). Como mencionado anteriormente, na maioria das vezes, será mais econômico utilizar uréia, a qual proporciona desempenhos semelhantes na mesma equivalência protéica.

Em vacas lactantes, Helmer et al. (1970a), Roman-Ponce et al. (1975), Stiles et al. (1975b), Jones et al. (1975), Teller et al. (1982) e Carmo (2001) não observaram diferenças na produção de leite entre os tratamentos com amiréia ou farelo de soja. Randel et al. (1975), trabalhando com dois teores de proteína (10 e 12\%) e dois teores de amiréia (1,9 e 0,95\% de equivalente uréia na ração total) e comparando-os ao farelo de soja, observaram uma redução na produção de leite no menor teor de proteína (10\%) e porcentagem 
de proteína do leite no tratamento com amiréia, sendo as demais variáveis iguais dentro de cada porcentagem de proteína. Dentro dos teores de proteína, a produção de leite corrigida para gordura não diferiu entre $\propto$ tratamentos. Fernandes et al. (2001), trabalhando com cabras lactantes, não observaram diferenças na produção de leite, entre amiréia (150S) e farelo de soja.

\subsection{Bagaço de cana-de-açúcar in natura em dietas com alto teor de concentrado}

O bagaço de cana-de-açúcar in natura (BIN) é o resíduo de maior volume da agroindústria brasileira, sendo que cada tonelada de cana moída produz cerca de $250-300 \mathrm{~kg}$ de bagaço e parte deste material (75 a 100\%) é utilizado na própria usina como fonte energética, porém, até $25 \%$ deste material pode ser usado para outros fins, tais como na alimentação de ruminantes. Sua baixa densidade, aliado a um reduzido valor comercial, limita seu transporte a longas distâncias (Burgi, 1985).

O uso de dietas de alto teor de concentrado fornecido ad libitum é prática comum na indústria de gado de corte norte-americana (Preston, 1998).

No Brasil, as dietas de bovinos em confinamento são tradicionalmente balanceadas com alta proporção de volumosos. Em épocas de preços vantajosos de concentrados, dietas com alto teor de concentrado têm se tornado viáveis economicamente, já que o ganho de peso é mais rápido, havendo redução no custo de mão-de-obra e tornando a atividade mais rentável. Neste tipo de dieta, a fonte de volumoso entra apenas com a função de estimular a ruminação e salivação, bem como formar uma malha de fibra no rúmen, aumentando o tempo de permanência do alimento. Este efeito é obtido pela chamada fibra íntegra (Bulle, 2000).

Woody et al. (1983), estudando o efeito do teor de concentrado nas dietas de bovinos em acabamento, observaram que animais alimentados 
com dietas com alta proporção de concentrado (90\%) ganharam $7 \%$ mais peso e apresentaram exigências alimentares $16 \%$ menor por unidade de ganho do que animais alimentados com $70 \%$ de concentrado.

$O$ bagaço in natura é rico em constituintes de parede celular, ou seja, é uma fonte de fibra interessante para dietas de confinamentos. A fibra é um componente da dieta de ruminantes, com finalidade nutritiva e de estimular a mastigação e motilidade ruminal (fibra efetiva). Com a mastigação, ocorre a produção de saliva, que tem poder tamponante natural e que irá neutralizar os ácidos produzidos na fermentação, mantendo assim, um ambiente ruminal estável (Allen, 1997) e, conseqüentemente, um animal saudável, com boa produção e longevidade. Para que isto ocorra, é necessário que a fibra da dieta, seja fornecida em quantidade e qualidade adequada para o animal (Eastridge, 1997).

Thiago et al. (1983), estudando a substituição de BIN em dietas de novilhos em engorda, demonstraram que a inclusão de BIN em teores superiores a $40 \%$ da MS em substituição a ponta de cana prejudicou o desempenho dos animais, sugerindo como máximo $20 \%$ da MS.

Estudando o BIN como fonte de fibra efetiva Henrique et al., (1999) concluíram que o BIN pode ser utilizado como única fonte de fibra em dietas com alta proporção de grãos (88\%).

Bulle et al. (2002a), utilizando tourinhos de dois tipos genéticos, resultado do cruzamento de vacas Caracu x Nelore com pais Guelbvieh ou pais Shorthorn, sendo o BIN a única fonte de fibra íntegra na dieta nos teores de 9, 15 e $21 \%$ da matéria seca. Concluíram que dietas com $15 \%$ de BIN apresentaram ganhos superiores aos teores de $9 \%$ e $21 \%$ de BIN. Entretanto, não houve diferença na eficiência alimentar, provavelmente, em função da queda no consumo da dieta de maior teor de concentrado, sugerindo que em dietas com alta proporção de concentrado e de teores de bagaço in natura de apenas $9 \%$ podem ser utilizados. 
Os teores (9; 15 e 21\%) de BIN não alteraram a composição do ganho, provavelmente, porque todas as dietas apresentavam altas proporções de concentrados e da conseqüente pequena diferença no ganho de peso entre os tratamentos (Bulle et al. 2002b).

Dietas com alta proporção de concentrado, onde o BIN entra apenas para fornecer fibra efetiva, são raros os trabalhos com este objetivo. Portanto, são necessárias mais informações para o seu uso racional, permitindo o máximo desempenho e lucratividade, mantendo a saúde do animal. 


\section{SUBSTITUIÇÃO TOTAL DO FARELO DE SOJA POR URÉIA OU AMIRÉIA, EM DIETAS COM ALTO TEOR DE CONCENTRADO, SOBRE A DIGESTIBILIDADE DOS NUTRIENTES, BALANCCO DE NITROGÊNIO, PARÂMETROS RUMINAIS E SANGUÍNEOS EM BOVINOS DE CORTE}

\section{Resumo}

Seis machos da raça Nelore, não castrados, com peso médio inicial de $420 \mathrm{~kg}$, foram utilizados em um delineamento de quadrado latino $3 \times 3$ duplicado, para avaliar a substituição de uma fonte de proteína verdadeira (farelo de soja - dieta deficiente em PDR), por uréia ou amiréia (fonte de nitrogênio não protéico de suposta liberação gradativa de nitrogênio - dietas adequada em PDR). Foram avaliados: a digestibilidade dos nutrientes, o balanço de nitrogênio, parâmetros ruminais e sanguíneos, degradabilidade in situ do farelo de soja e da amiréia e a "proteção de cocho" da amiréia. Os tratamentos foram: 1) farelo de soja (FS); 2) uréia e 3) amiréia (A-150S). As dietas foram isoprotéicas (13,0\%), utilizando-se o bagaço de cana-de-açúcar in natura (BIN) como única fonte de volumoso (20\% da MS). O tratamento FS promoveu um menor $(P<0,05)$ consumo de MS, MO, FDA, FDN e NDT e também um menor $(P<0,05)$ consumo digestível $(\mathrm{kg} / \mathrm{d})$ da MS, MO, FDN e FDA, comparado aos tratamentos com uréia e amiréia. Os tratamentos uréia e amiréia apresentaram resultados similares $(P>0,05)$. A digestibilidade da $M S$, $\mathrm{MO}, \mathrm{CNF}, \mathrm{EE}, \mathrm{PB}$ e o NDT não diferiram $(\mathrm{P}>0,05)$ entre os tratamentos. As digestibilidades da FDA e FDN foram superiores $(P<0,05)$ nos tratamentos uréia 
e amiréia. Não houve efeito de tratamento e da interação tratamento $\mathrm{x}$ horários $(P>0,05)$ nos valores de $\mathrm{pH}, \mathrm{AGV}$ total, acetato, propionato, butirato e relação acetato:propionato do fluido ruminal. A concentração de nitrogênio amoniacal no fluido ruminal foi superior $(P<0,05)$ no tratamento com uréia, comparado ao tratamento com farelo de soja, sendo que o tratamento com amiréia não diferiu dos demais. Observou-se uma maior $(\mathrm{P}<0,05)$ concentração molar do valerato, isobutírato, isovalerato no tratamento com farelo de soja, não havendo diferença $(P>0,05)$ entre os tratamentos com uréia e amiréia $O$ tratamento com amiréia apresentou uma maior $(P<0,05)$ perda de $N$ urinário. $A$ retenção de $N$ ( $\mathrm{g} / \mathrm{d}$ e \% do consumido) e o valor biológico da proteína ( $\mathrm{N}$ retido, \% do $\mathrm{N}$ absorvido) foram superiores $(\mathrm{P}<0,05)$ para o tratamento com uréia, comparado aos demais. A concentração de nitrogênio uréico no plasma e a concentração de glicose plasmática foram similares $(P>0,05)$ entre os tratamentos. $O$ nitrogênio da amiréia estava quase todo $(88,2 \%)$ na forma prontamente solúvel em água (fração "a") e não apresentou "proteção de cocho". A substituição total de farelo de soja por uréia ou amiréia, ajustando a PDR na dieta de bovinos de corte, demonstrou ser viável, com possíveis ganhos em desempenho. A amiréia não apresentou vantagens em relação àuréia na forma convencional.

\section{TOTAL REPLACEMENT OF SOYBEAN MEAL BY UREA OR STAREA, IN HIGH GRAIN DIETS, ON NUTRIENT DIGESTIBILITY, NITROGEN BALANCE, RUMINAL AND BLOOD PARAMETERS IN BEEF CATTLE}

\section{Summary}

Six Nellore bulls, with $420 \mathrm{~kg}$ of initial body weight, were used to evaluate the effects of replacing a true protein source (soybean meal - SBM) of high biological value, in a RDP deficient diet, by urea or starea (a supposedly slow release nonprotein nitrogen source), both in a RDP adjusted diets, on 
nutrient digestibility, nitrogen balance, in situ degradability of soybean meal and starea and "feeder protection" of starea, ruminal and blood parameters in beef cattle. In natura sugarcane bagasse was the only source of forage ( $20 \%$ of DM). SBM treatment reduced $(\mathrm{P}<0.05) \mathrm{DM}, \mathrm{OM}, \mathrm{ADF}, \mathrm{NDF}$ and TDN intake and also decreased $(P<0.05)$ DM, OM, NDF and ADF digestibilities $(\mathrm{kg} / \mathrm{d})$ compared with urea and starea treatments. There was no difference between urea and starea treatments. There were no differences $(P>0.05)$ in DM, OM, NFC, EE, PB and TDN apparent digestibility (\%) among treatments. ADF and NDF digestibilities $(\%)$ were higher $(\mathrm{P}<0.05)$ for urea and starea treatments. There was no treatment effect and interaction teatment $x$ time $(P>0.05)$ for $\mathrm{pH}$ values, total rumen VFA molar concentration and acetate, propionate, butyrate and acetate:propionate ratio. The molar concentration of valerate, isobutyrate, isovalerate and branched-chain FA were higher $(\mathrm{P}<0.05)$ for SBM treatment. There were no differences $(P>0.05)$ between urea and starea. Starea had higher $(\mathrm{P}<0.05)$ loss of urinary $\mathrm{N} . \mathrm{N}$ retention $(\mathrm{g} / \mathrm{d}$ and $\%$ of consumed) and protein biological value were higher $(P<0.05)$ for urea treatment, compared to the others; there was no difference on plasma urea- $\mathrm{N}$ and glucose concentration $(P>0.05)$ among treatments. Starea $N$ was $88,2 \%$ water soluble (a) and showed no "feeder protection". Total replacement of SBM by urea or starea, adjusting RDP for growing beef cattle, had no detrimental effect, with possible performance improvement. Starea showed no advantage compared to conventional urea.

\subsection{Introdução}

O modelo de proteína metabolizável proposto no NRC (1996) divide as estimativas das exigências protéicas em proteína degradável no rúmen (PDR), a qual deve suprir as exigências dos microrganismos ruminais e proteína não degradável no rúmen (PNDR), a qual deve complementar a 
proteína microbiana que chega no intestino. Isto foi um avanço, pois sabe-se que é de fundamental importância a síntese de proteína microbiana e, para que esta ocorra, é necessário que se tenha PDR, em quantidade e qualidade $\left(\mathrm{NH}_{3}\right.$, peptídeo e aminoácidos; Russell et al., 1992) afim de atingir a máxima eficiência. As exigências de proteína do NRC (1996) geralmente são superiores a do NRC (1984) devido, principalmente, ao componente microbiano (PDR).

As bactérias fermentadoras de fibras utilizam amônia como única fonte de $\mathrm{N}$, sendo estas altamente prejudicadas quando há deficiência de nitrogênio no rúmen, levando a um menor desaparecimento da fibra, diminuindo a taxa de passagem e, conseqüentemente, diminuindo o consumo de matéria seca (Russell et al., 1983, 1992 e Tedeschi et al., 2000). Esta amônia pode ser fornecida via uréia, embora, apresente uma alta solubilidade no rúmen, limitando o seu uso. Uma maneira de melhorar esse problema é o emprego de complexos de liberação lenta de uréia (Owens \& Zinn, 1988), como a amiréia, melhorando o fornecimento de amônia no rúmen e aumentando a síntese de proteína microbiana, o consumo de matéria seca, a digestibilidade da fibra e um maior consumo de energia pelo animal, além de reduzir problemas com toxidez (Bartley \& Deyoe, 1975).

A gelatinização do amido realizada no procedimento da fabricação da amiréia pode promover um aumento na proporção de ácido propiônico e uma redução na proporção de ácido acético, sendo a produção total de ácidos graxos voláteis totais aumentada e a concentração de amônia ruminal reduzida com o aumento da gelatinização do amido (Wilson \& Woods, 1966 e 1967 e Mendes Junior, 1999).

Comparações entre uréia e amiréia na retenção de nitrogênio em borregos (Shiehzadeh \& Harbers, 1974; Silva et al., 1994 e Salman et al., 1997) ou em vacas lactantes (Teller et al., 1982 e Teller \& Godeau 1986) tem apresentado resultados diversos, não permitindo uma conclusão sobre o assunto. Faltam trabalhos que avaliem o balanço de nitrogênio em bovinos de 
corte, pois a amiréia apresenta uma fonte de amido com alta taxa de degradação e uma suposta liberação mais lenta de amônia.

Dietas com alta proporção de concentrado, onde o BIN entra apenas para fornecer fibra efetiva, são raros os trabalhos com este objetivo (Henrique et al., 1999). Portanto, são necessárias mais informações para o seu uso racional, permitindo o máximo desempenho e lucratividade, mantendo a saúde do animal.

O objetivo do presente trabalho foi comparar a substituição total de uma fonte de proteína verdadeira (farelo de soja), em uma dieta deficiente em PDR, por uréia ou amiréia (fonte de nitrogênio não protéico de suposta liberação gradativa de nitrogênio), ambas em uma dieta adequada em PDR, utilizando o BIN como única fonte de volumoso (20\% da MS), sobre a digestibilidade dos nutrientes, o balanço de nitrogênio, parâmetros ruminais e sanguíneos de bovinos de corte confinados, a degradabilidade in situ do farelo de soja e da amiréia e a "proteção de cocho" da amiréia.

\subsection{Material e métodos}

\subsubsection{Animais e instalações experimentais}

Foram utilizados seis garrotes mestiços da raça Nelore com cânula no rúmen e duodeno proximal, com peso médio inicial de $420 \mathrm{~kg}$, distribuídos em um quadrado latino 3x3 duplicado.

$O$ experimento foi conduzido nas instalações experimentais de bovinos do Departamento de Zootecnia ESALQ-USP. Os animais foram alojados em baias individuais cobertas, do tipo "tie stall" (1×2,2m), providas de bebedouros automáticos e cocho para alimentação. O período experimental foi realizado durante o período de fevereiro a abril de 2001. 


\subsubsection{Tratamentos}

Os animais foram alimentados com dietas contendo bagaço de cana-de-açúcar in natura (BIN) como volumoso $(20 \%)$ e $80 \%$ de concentrado (Tabela 4), sendo que os tratamentos experimentais foram feitos pela substituição da fonte de proteína verdadeira (farelo de soja), em uma dieta deficiente em PDR, por uréia ou amiréia (fonte de nitrogênio não protéico de suposta liberação gradativa de nitrogênio), sendo as duas fontes utilizadas em uma dieta adequada em PDR.

As fontes de uréia utilizadas foram: a uréia (adubo convencional) e a uréia extrusada, utilizando-se o milho como a fonte de amido (Amiréia $150 S^{\circledR}$, Pajoara indústria e comércio, Campo Grande, MS).

Os tratamentos (Tabela 4) foram formulados para resultarem em dietas isoprotéicas e isoenergéticas, utilizando o programa do NRC (1996) de bovinos de corte. 
Tabela 4. Composição em ingredientes e composição química das dietas (\% da MS).

\begin{tabular}{|c|c|c|c|}
\hline \multirow{2}{*}{ Ingredientes } & \multicolumn{3}{|c|}{ Tratamentos } \\
\hline & FS & Uréia & A-150S \\
\hline$\overline{\text { Bagaço in natura (BIN) }}$ & 20,5 & 20,5 & 20,5 \\
\hline Milho moído & 27,5 & 33,2 & 30,9 \\
\hline Polpa cítrica & 33,1 & 41,0 & 41,0 \\
\hline Farelo de soja (FS) & 16,5 & - & - \\
\hline Uréia & - & 2,46 & - \\
\hline Amiréia (A-150S) & - & - & 4,78 \\
\hline Mistura mineral $^{1}$ & 1,37 & 1,37 & 1,37 \\
\hline Cloreto de potássio & - & 0,41 & 0,41 \\
\hline Bicarbonato de sódio & 1,09 & 1,09 & 1,09 \\
\hline \multicolumn{4}{|l|}{ Composição química } \\
\hline MS (\% da matéria natural) & 73,4 & 74,3 & 71,4 \\
\hline Proteína bruta & 13,4 & 13,2 & 13,2 \\
\hline Fibra em detergente neutro & 28,5 & 28,5 & 28,3 \\
\hline Fibra em detergente ácido & 23,8 & 24,2 & 24,1 \\
\hline Carboidratos não fibrosos ${ }^{2}$ & 50,1 & 50,4 & 51,0 \\
\hline Matéria mineral & 4,3 & 3,8 & 3,8 \\
\hline Extrato etéreo & 3,7 & 4,1 & 3,7 \\
\hline Lignina & 4,3 & 4,6 & 4,5 \\
\hline
\end{tabular}

Os concentrados foram misturados previamente em um misturador horizontal (marca Lucato, capacidade de $250 \mathrm{~kg}$ ). Na hora do 
fornecimento da alimentação, o BIN e o concentrado, nas suas respectivas proporções, foram misturados manualmente e fornecidos como ração completa duas vezes ao dia (6 e 18 horas).

\subsubsection{Período experimental}

O período experimental teve duração de 84 dias, sendo os primeiros 30 dias destinados ao processo de adaptação dos animais æ̀ instalações e æ̀s dietas experimentais; e o restante do período, foi segmentado em três sub-períodos de 18 dias, sendo destinado os 14 primeiros dias dos sub-períodos para adaptação dos animais às novas dietas e os quatro últimos dias para colheita de dados e amostras.

\subsubsection{Colheita de dados referentes ao consumo de matéria seca}

Os dados de consumo de MS por animal por dia foram obtidos através da diferença entre a quantidade de MS fornecida e a da sobra. As amostras das dietas fornecidas e das sobras do $15^{0}$ ao $18^{0}$ dia foram amostradas uma vez por dia e compostas por animal dentro de cada subperíodo.

As amostras foram conservadas congeladas a $-10^{\circ} \mathrm{C}$ até serem descongeladas e secas em estufas com ventilação forçada $\left(55^{\circ} \mathrm{C}\right)$ por 72 horas e posteriormente, por 12 horas a $105^{\circ} \mathrm{C}$ para determinação de matéria seca, de acordo com Silva (1990). 


\subsubsection{Colheita de amostras para determinação da digestibilidade aparente no trato digestivo total}

Foram realizadas colheitas das amostras de fezes, da porção final do reto, nos quatro últimos dias de cada sub-período à cada oito horas, adiantando duas horas por dia, de maneira que se obtivesse uma amostra a cada duas horas no intervalo de 24 horas depois do término dos quatro dias de colheita.

As amostras foram compostas por animal e período, acondicionadas em sacos plásticos e congeladas a $-10^{\circ} \mathrm{C}$. Posteriormente, estas amostras foram descongeladas homogenizadas e amostrado uma porção de $200 \mathrm{~g}$ do material. Essa porção foi seca em estufa com ventilação forçada $\left(55^{\circ} \mathrm{C}\right)$ por 72 horas e moídas em moinhos do tipo Wiley (Marconi, Piracicaba, $\mathrm{SP})$ primeiramente em peneira com crivos de $2 \mathrm{~mm}$ e após em peneira com crivos de $1 \mathrm{~mm}$. Posteriormente, esta amostra voltou a estufa, por 12 horas a $105^{\circ} \mathrm{C}$ para determinação de matéria seca de acordo com Silva (1990).

Para determinação do cromo utilizou-se a metodologia de fluorescência de raios $X$, no laboratório de Instrumentação Nuclear do Centro de Energia Nuclear na Agricultura, CENA-USP, descrita por Korndorfer et al. (2001).

As amostras de oferecido, sobras e fezes foram conservadas congeladas a $-10^{\circ} \mathrm{C}$, para posterior determinação de matéria seca (MS), nitrogênio $(\mathrm{N})$, fibra detergente neutro (FDN), fibra detergente ácido (FDA), lignina, extrato etéreo ( $\mathrm{EE})$, matéria mineral $(\mathrm{MM})$. A digestibilidade dos nutrientes foi calculada da seguinte maneira:

Digestibilidade (D) do nutriente (\%)

$$
D=100-\left(\begin{array}{cc}
100 \times \frac{\% \text { do marcador no alimento }}{\% \text { do marcador nas fezes }} \times \frac{\% \text { do nutriente nas fezes }}{\% \text { do nutriente no alimento }}
\end{array}\right)
$$




\subsubsection{Colheita de amostras para determinação da digestibilidade aparente no rúmen e intestinos}

Inicialmente, a digestibilidade aparente no rúmen e intestinos seria determinada através da utilização do óxido de cromo $\left(\mathrm{Cr}_{2} \mathrm{O}_{3}\right)$, como marcador externo de indigestibilidade, sendo esse fornecido no rúmen duas vezes ao dia (5,0 g/dose a cada 12 horas), via cânula ruminal, iniciando dez dias antes do término das colheitas de cada período.

As amostras do conteúdo duodenal foram colhidas a cada quatro horas, com o horário inicial avançado de uma hora, em cada dia de cada período. Após a colheita das amostras, estas foram compostas por animal e por período, congeladas a $-10^{\circ} \mathrm{C}$, visando a sua conservação, para posterior secagem em estufa com ventilação forçada $\left(55^{\circ} \mathrm{C}\right)$ por 72 horas e moídas em moinhos do tipo Wiley (Marconi, Piracicaba, SP) primeiramente em peneira com crivos de $2 \mathrm{~mm}$ e posteriormente em peneira com crivos de $1 \mathrm{~mm}$, para determinação de lignina, cromo, N, EE, FDN, FDA, MS e MM.

A digestibilidade no rúmen seria calculada através da concentração dos nutrientes e do marcador externo de indigestibilidade no alimento consumido e no conteúdo duodenal. No entanto, os resultados apresentados pelas análises não foram satisfatórios e condizentes com a literatura, não sendo possível determinar a causas dos problemas da recuperação de cromo e conseqüente impedimento da determinação da digestibilidade aparente no rúmen e intestinos. A análise de cromo utilizada foi por fluorescência de raios $X$, no laboratório de Instrumentação Nuclear do Centro de Energia Nuclear na Agricultura, CENA-USP, descrita por Korndorfer et al. (2001). 


\subsubsection{Análise bromatológica das dietas, sobras e fezes}

As amostras do alimento oferecido, sobras e fezes foram secas em estufas com ventilação forçada à temperatura de $55^{\circ} \mathrm{C}$ por 72 horas e moídas em moinhos tipo Wiley (Marconi, Piracicaba, SP) primeiramente em peneira com crivos de $2 \mathrm{~mm}$ e após em peneira com crivos de $1 \mathrm{~mm}$. Posteriormente, esta amostra voltou a estufa por 12 horas a $105^{\circ} \mathrm{C}$ para determinação de matéria seca de acordo com Silva (1990); MM, EE e N de acordo com AOAC (1990); FDN e FDA de acordo com o método de Van Soest et al. (1991), não seqüencial, utilizando amilase e sulfito de sódio nas determinações de FDN e lignina de acordo com Goering \& Van Soest, (1970). O EE nas fezes foi determinado com éter de petróleo adicionado de $10 \%$ de ácido acético, para liberar os ácidos graxos (Mattos \& Palmquist, 1974). A MO foi obtida pela subtração da MM da MS. Os carboidratos não fibrosos (CNF) pela fórmula: $100-(F D N+P B+E E+M M)$.

\subsubsection{Colheita de amostras para determinação do balanço de nitrogênio}

\subsection{Colheita de amostras da urina}

A colheita total de urina foi realizada durante 48 horas $\left(15^{0}\right.$ e $16^{0}$ dias), em todos os sub-períodos, sendo colhida a cada 24 horas (Valadares et al., 1997b). Foram utilizados funis (napa) fixados por alças elásticas no dorso dos animais (Valadares et al., 1997a). A urina foi conduzida por intermédio de mangueira de borracha até um saco plástico contendo $200 \mathrm{~mL}$ de solução de ácido sulfúrico a 30\%, mantendo o $\mathrm{pH}$ final da urina sempre menor que 3,0. Após a pesagem e homogeneização da urina, ela foi filtrada em gaze cirúrgica, colhendo aproximadamente $30 \mathrm{~mL}$, sendo colocada em frascos de vidro com 
tampa e armazenado a $-10^{\circ} \mathrm{C}$ para posterior análise (Chen \& Gomes, 1992). O nitrogênio da urina foi analisado no macro Kjeldahl segundo a AOAC (1990).

\subsubsection{Colheita de conteúdo ruminal para determinação de ácidos graxos voláteis (AGV), nitrogênio amoniacal $\left(\mathrm{N}-\mathrm{NH}_{3}\right)$ e $\mathrm{pH}$ ruminal}

As amostras de conteúdo ruminal foram colhidas no último dia de colheita de cada sub-período (décimo oitavo dia), com intervalos de duas horas entre cada colheita. Os horários de colheita foram determinados obedecendo aos horários da alimentação, sendo que a hora zero foi antes do fornecimento da dieta pela manhã e 2, 4, 6, 8, e 10 horas após o fornecimento da dieta.

As amostras de conteúdo ruminal foram colhidas de quatro pontos diferentes da cavidade e depois filtrada em duas camadas de tecido de algodão (fraldas), obtendo-se desta forma, aproximadamente $200 \mathrm{~mL}$ de fluido ruminal filtrado, que foram utilizados para determinação imediata do $\mathrm{pH}$ de cada amostra. Esses valores foram determinados através de leitura em peagômetro digital (Digimed, modelo TE-902).

Após a determinação do pH foram retiradas duas alíquotas de 25 $\mathrm{mL}$ do fluido ruminal, acrescentando $1,25 \mathrm{~mL}$ de solução $6 \mathrm{~N}$ de ácido clorídrico e conservando-as congeladas a $-10^{\circ} \mathrm{C}$ para posterior determinação de AGV e $\mathrm{N}-\mathrm{NH}_{3}$.

Após o descongelamento, as amostras foram centrifugadas a $11.000 \mathrm{~g}$ a $4^{\circ} \mathrm{C}$, durante 20 minutos, sendo uma alíquota utilizada para determinação dos AGV de acordo com Palmiquist \& Conrad (1971), utilizando um cromatógrafo líquido gasoso, CLG (Hewlett Packard 5890, series II) equipado com HP integretor (Jewlett - Pacard Company, Avondale, PA). A temperatura do injetor, detector e coluna foram: 150, 190 e $115^{\circ} \mathrm{C}$, respectivamente. 
A análise de $\mathrm{N}^{-\mathrm{NH}_{3}}$ foi realizada segundo o método calorimétrico descrito por Chaney \& Marbach (1962) e adaptado para ser usado em placas de microtítulo e posterior leitura em aparelho do tipo "ELISA READER" (absorvância de 550 nanômetros), o qual apresenta os resultados em mg/dL.

\subsubsection{Colheita de sangue para determinação de glicose e nitrogênio uréico no plasma}

As amostras de sangue foram colhidas no último dia de colheita de cada sub-período (décimo oitavo dia). As amostras de sangue foram colhidas na veia coccigena, em tubos "vacuntainer" contendo oxalato de potássio (anti-coagulante) e fluoreto de sódio (anti-glicolítico).

Os horários de colheita para determinação de nitrogênio uréico no plasma foram determinados obedecendo o horário da alimentação, sendo que a hora zero foi antes do fornecimento da dieta pela manhã e 2, 4, 6, 8 e 10 horas após o fornecimento da dieta.

Foi utilizado apenas o horário das 4 horas após a alimentação para determinação de glicose no plasma. As amostras foram centrifugadas a $4.000 \mathrm{~g}$ por 20 minutos à temperatura de $4^{\circ} \mathrm{C}$ para separação do plasma sanguíneo, o qual foi acondicionado em tubos do tipo "ependorf" e armazenado a $-10^{\circ} \mathrm{C}$ para posterior análise.

O nitrogênio uréico no plasma foi determinado através do método enzimático colorimétrico ("Kit" Labtest Diagnóstico SA, Lagoa Santa, MG), multiplicando-se o valor obtido por 0,45 (uréia contém $45 \%$ de $N$ ) para obter o nitrogênio uréico. A concentração plasmática de glicose foi determinada utilizando um método enzimático colorimétrico ("Kit" Laborlab Produtos para Laboratórios LTDA, Guarulhos, SP). 


\subsubsection{Degradabilidade in situ}

Foram utilizados os mesmos animais dos tratamentos FS e A $150 S$ (quatro). Os animais foram alimentados com ração completa (Tabela 4; tratamentos de FS e A-150S). O arraçoamento foi realizado duas vezes ao dia (6 e 18 horas).

Para determinação da degradabilidade in situ as amostras do farelo de soja e amiréia (em torno de $6,0 \mathrm{~g}$ ) foram moídas em peneira com crivos de $2 \mathrm{~mm}$, pesadas e colocadas nos sacos de poliéster de $10 \times 15 \mathrm{~cm}$ com porosidade média de $45 \mu \mathrm{m}$. Foram introduzidos no rúmen de cada animal quatro sacos de cada alimento por horário, todos em um mesmo horário (logo após a alimentação) e retirados gradativamente, respeitando os seguintes horários: 0, 2, 4, 8, 12, 24, 48 e 72 horas após a incubação ruminal.

Após a retirada do rúmen, todos os sacos foram imersos em água gelada por 10 minutos. Depois do choque térmico, os sacos foram lavados em água corrente por 5 minutos, juntamente com aqueles contendo amostras não incubadas (hora zero - para determinação da fração solúvel) e foram secos em estufa de circulação e remoção de ar forçada a $55^{\circ} \mathrm{C}$ por 72 horas.

Os resíduos obtidos foram pesados e moídos em peneiras com crivos de $1 \mathrm{~mm}$ para análise de PB segundo metodologia descrita na AOAC (1990), sendo misturado os resíduos de dois sacos (animal/horário) para a realização da análise. A determinação de PB na amiréia foi só até o horário de 8 horas e do farelo de soja até 48 horas; após estes horários, não havia resíduos suficientes.

Cada animal estava recebendo a mesma fonte protéica que foi colocada nos sacos de poliéster. Os dados das amostras incubadas foram processados utilizando o "software Fit Curve" desenvolvido pelo Rowett Research Institute, Aberdeen, Escócia, que fornece, dentre outras informações, os parâmetros do modelo de degradabilidade ruminal de Ørskov \& McDonald 
(1979). A degradabilidade potencial in situ da matéria seca (MS) e proteína bruta (PB) foram calculadas de acordo com a equação:

$$
\begin{aligned}
& d g=a+b\left(1-e^{-c t}\right) \\
& \text { Onde: } \\
& d g=\text { a degradabilidade estimada; } \\
& a=\text { fração rapidamente solúvel em água; } \\
& b=\text { fração insolúvel em água, mas potencialmente degradável; } \\
& c=\text { taxa de degradação da fração b; } \\
& \text { e = logaritmo natural e; } \\
& a+b=\text { potencial de degradabilidade. }
\end{aligned}
$$

A degradabilidade efetiva da matéria seca (MS) e proteína bruta (PB) foram calculadas pela equação de Ørskov \& McDonald (1979):

$$
p=a+b c / c+k \text {. }
$$

Onde:

ké a taxa de passagem.

Para o cálculo da digestibilidade efetiva deve-se considerar a taxa de passagem dos alimentos pelo rúmen. O ARC (1994) sugere valores de 2, 5 e $8 \% / \mathrm{h}$ para consumo menor, igual e maior que a mantença, respectivamente.

\subsubsection{Simulação da "proteção de cocho" da amiréia}

Em uma condição onde o cocho de alimentação está sujeito a represar água proveniente de chuva, tem sido sugerido pela indústria que a amiréia apresenta vantagem sobre a uréia em termos de "proteção de cocho", ou seja, ela impede a solubilização imediata da uréia (constituinte da amiréia), 
reduzindo os possíveis riscos de intoxicação dos animais, quando estes ingerem a água presente no cocho. O objetivo desta simulação foi avaliar esta possível "proteção de cocho".

Foram pesadas quatro porções de $20 \mathrm{~g}$ de amiréia, as quais foram colocadas uma em cada Becker $(600 \mathrm{~mL})$. Também foi pesado $10 \mathrm{~g}$ de uréia (a mesma quantidade de uréia presente em $20 \mathrm{~g}$ de amiréia $150 \mathrm{~S}^{\circledR}$ ), colocada em um Becker e foi adicionado, simultaneamente, $200 \mathrm{~mL}$ de água destilada $\left(22^{\circ} \mathrm{C}\right)$ em todos os Beckers, iniciando a contagem do tempo. Após 40 mim (T0), a uréia foi totalmente solubilizada, ou seja, não havia mais grânulos de uréia no fundo do Becker. Neste instante, foi filtrado o conteúdo de dois Beckers (repetições 1 e 2) e imediatamente iniciou-se a análise de nitrogênio no líquido no macro Kjeldahl segundo a AOAC (1990).

Após 2 horas (T2), o mesmo procedimento descrito acima foi realizado para os outros dois Beckers restantes. Foi analisado o nitrogênio da amiréia in natura no mesmo procedimento anterior, possibilitando o cálculo da proporção do nitrogênio total que era prontamente solúvel em água, sem que fosse feito uma lavagem como no procedimento in situ. Em momento algum, o conteúdo do Becker foi agitado, simulando uma condição natural de água (chuva) no cocho com amiréia.

\subsubsection{Delineamento experimental e análise estatística}

O experimento foi conduzido em um delineamento experimental quadrado latino $3 \times 3$ duplicado (seis animais e três tratamentos), adotando-se para análise estatística o procedimento GLM do programa estatístico SAS (1988). O quadro de análise de variância está apresentado no Quadro 1. Foi utilizado o seguinte modelo estatístico: 
$Y_{i j k}=M+Q_{i}+A_{j}+P_{k}+F N_{l}+E_{i j k}$

Onde:

$M=$ Média geral

$Q_{i}=$ Efeito de quadrado

$A_{j}=$ Efeito de animal

$P_{k}=$ Efeito de período

$\mathrm{FN}_{\mathrm{l}}=$ Efeito das fontes nitrogenadas

$\mathrm{E}_{\mathrm{ijkl}}=$ Efeito aleatório

\begin{tabular}{|lc|}
\hline Causa de variação & Graus de liberdade \\
\hline Animal & 5 \\
Período & 2 \\
Tratamento & 2 \\
Quadrado & 1 \\
Resíduo & 7 \\
\hline Total & 17 \\
\hline
\end{tabular}

Quadro 1- Esquema da análise da variância para consumo, digestibilidade dos nutrientes, balanço de nitrogênio e glicose plasmática.

As variáveis $\mathrm{pH}, \mathrm{AGV}, \mathrm{N}-\mathrm{NH}_{3}$ e $\mathrm{N}$-uréico foram analisadas estatisticamente como parcelas subdivididas no tempo $e$ analisadas estatisticamente pelo PROC MIXED, que define as variáveis fixas e aleatórias para execução da análise. Os efeitos de tratamento, animal e período foram testados com relação às parcelas. A interação horário de colheita $x$ tratamentos foi testada com relação æ̀ sub-parcelas. O quadro da análise de variância está demonstrado no Quadro 2. 
Considerou-se 5\% $(\mathrm{P}<0,05)$ como nível de significância e até $10 \%$ como tendência $(P<0,10)$ para a probabilidade do teste $F$ na análise da variância. Para as variáveis que obtiveram respostas significativas, utilizou-se o teste Tukey e o comando LSMEANS/PDIFF para verificar as diferenças entre os tratamentos para as diversas variáveis. As médias das tabelas foram obtidas pelo comando LSMEANS (ajuste pelos quadrados mínimos) para as parcelas e sub-parcelas.

\begin{tabular}{|lc|}
\hline Causa de variação & Graus de liberdade \\
\hline Animal & 5 \\
Período & 2 \\
Tratamento & 2 \\
Quadrado & 1 \\
Resíduo A & 7 \\
\hline Parcelas & 17 \\
\hline Horário de colheita & 5 \\
Tratamento & 2 \\
Horário de colheita x tratamento & 10 \\
Resíduo B & 91 \\
\hline Sub-parcelas & 108 \\
\hline
\end{tabular}

Quadro 2- Esquema da análise de variância para pH, AGV, N-NH ${ }_{3}$ e Nuréico. 


\subsection{Resultados e discussão}

\subsubsection{Consumo e digestibilidade dos nutrientes no trato digestivo total}

\subsubsection{Matéria seca e matéria orgânica}

Os dados de consumo e digestibilidade aparente da matéria seca e matéria orgânica no trato digestivo total estão apresentados na Tabela 5.

O tratamento com farelo de soja apresentou menor $(\mathrm{P}<0,05)$ consumo de matéria seca em relação aos com nitrogênio não protéico (uréia e amiréia). O menor consumo de matéria seca no tratamento com farelo de soja possivelmente ocorreu devido a menor fração de proteína degradável no rúmen.

Alterações no consumo ocorrem quando a quantidade de proteína dietética não é suficiente para produzir quantidade adequada de amônia ruminal, sendo importante conhecer as frações protéicas da proteína da dieta (Ørskov, 1988). Segundo os modelos NRC (1996) e CNCPS (Fox et al., 2000) o balanço de nitrogênio no rúmen ficou negativo no tratamento com farelo de soja.

As bactérias fermentadoras de carboidratos fibrosos utilizam amônia como única fonte de nitrogênio, sendo estas altamente prejudicadas quando ocorre uma deficiência de nitrogênio degradável no rúmen, levando a um menor desaparecimento dos carboidratos fibrosos, diminuindo assim, a taxa de passagem e, conseqüentemente, o consumo de matéria seca (Russel et al., 1992 e Tedeschi et al., 2000).

Alguns autores (Thompson et al., 1972; Schmidt et al., 1973;

Seixas et al., 1999 e Teixeira et al., 2000), utilizando novilhos em crescimento, observaram resultados similares aos encontrados neste experimento, no tocante ao consumo de matéria seca, quando compararam amiréia e uréia. Por outro lado, não verificaram alterações no consumo de matéria seca quando 
avaliaram fontes de nitrogênio não protéico (uréia e amiréia) com farelo de soja (Thompson et al., 1972; Schmidt et al., 1973 e Teixeira et al., 2000) ou farelo de algodão (Seixas et al., 1999).

Tabela 5. Consumo e digestibilidade aparente da matéria seca e matéria orgânica no trato digestivo total em bovinos de corte suplementados com fontes nitrogenadas.

\begin{tabular}{|c|c|c|c|c|c|}
\hline \multirow{2}{*}{ Itens $^{1}$} & \multicolumn{3}{|c|}{ Tratamentos $^{2}$} & \multirow{2}{*}{$\mathrm{EPM}^{3}$} & \multirow{2}{*}{$\mathrm{P}^{4}$} \\
\hline & FS & Uréia & A-150S & & \\
\hline \multicolumn{6}{|c|}{ Matéria seca } \\
\hline Consumo, $\mathrm{kg} / \mathrm{d}$ & $5,85^{\mathrm{b}}$ & $7,55^{\mathrm{a}}$ & $7,55^{\mathrm{a}}$ & 0,42 & 0,0473 \\
\hline CMSD, $\mathrm{kg} / \mathrm{d}$ & $3,93^{b}$ & $5,75^{a}$ & $5,76^{a}$ & 0,38 & 0,0479 \\
\hline DATT, \% & 67,1 & 76,1 & 76,3 & 1,47 & 0,1158 \\
\hline \multicolumn{6}{|c|}{ Matéria orgânica } \\
\hline Consumo, $\mathrm{kg} / \mathrm{d}$ & $5,52^{b}$ & $7,13^{a}$ & $7,12^{\mathrm{a}}$ & 0,38 & 0,0436 \\
\hline CMOD, $\mathrm{kg} / \mathrm{d}$ & $3,91^{b}$ & $5,59^{a}$ & $5,61^{\mathrm{a}}$ & 0,39 & 0,0442 \\
\hline DATT, $\%$ & 70,8 & 78,4 & 78,8 & 1,29 & 0,1161 \\
\hline
\end{tabular}

Stiles et al. (1970) sugeriram que a extrusão provoca a incorporação da uréia na estrutura do amido, promovendo uma melhor aceitabilidade do concentrado. Neste sentido, Salman et al. (1997) sugeriram que amiréia pode aumentar a aceitação da uréia das rações por parte dos animais, não ocorrendo isto no atual experimento, onde o consumo de matéria seca do tratamento com uréia e amiréia foram similares. 
A digestibilidade aparente da matéria seca em porcentagem não diferiu entre os tratamentos $(P>0,05)$. $O$ menor consumo e numericamente a menor porcentagem de digestibilidade da matéria seca no tratamento com farelo de soja, proporcionou um menor $(\mathrm{P}<0,05)$ consumo de matéria seca digestível (kg/d; Tabela 5).

Resultados semelhantes na digestibilidade aparente da matéria seca no trato digestivo total foram observados por Silva et al. (1994) em ovinos (independente do teor de palha de arroz, 50 ou 70\%) e por Jones et al. (1975), Teller et al. (1982) e Carmo (2001) em vacas leiteiras. Todos os autores utilizaram as mesmas fontes nitrogenadas do atual experimento.

Silva et al. (2002) não observaram diferenças também na digestibilidade da MS e MO, quando utilizaram farelo de soja (que possui proteína de média degradabilidade); amiréia (fonte de NNP) e farinha de subprodutos de abatedouro avícola (fonte de proteína de baixa degradabilidade), em novilhos confinados.

Ezequiel et al. (2001b), em um estudo de digestibilidade in vitro, verificaram uma maior digestibilidade da matéria seca no tratamento com uréia, quando comparado a amiréia e farelo de algodão (72,7; 69,8 e 70,5\%, respectivamente), discordando dos resultados do atual experimento, embora os valores absolutos sejam próximos aos observados neste. Utilizando os mesmos tratamentos do experimento anterior (Ezequiel et al., 2001b), Salman et al. (1997) observaram um coeficiente de digestibilidade da MS superior para o tratamento com amiréia em ovinos.

Shiehzadeh \& Harbers (1974) suplementaram ovinos com farelo de soja e amiréia com sorgo e batata como fonte de amido, ambas com baixo e alto grau de gelatinização do amido, e observaram apenas uma redução na digestibilidade da MS no tratamento com amiréia formada por batata com baixo grau de gelatinização. As demais dietas foram semelhantes.

A matéria orgânica apresentou comportamento muito semelhante ao da MS, onde a digestibilidade aparente em porcentagem não diferiu entre os 
tratamentos $(P>0,05)$. Um menor $(P<0,05)$ consumo de matéria orgânica digestível $(\mathrm{kg} / \mathrm{d})$ no tratamento com farelo de soja foi observado, uma vez que este apresentou um menor $(\mathrm{P}<0,05)$ consumo de matéria orgânica total. Dados semelhantes da digestibilidade aparente da matéria orgânica foram obtidos por Silva et al. (1994) quando suplementaram ovinos com amiréia, uréia e farelo de soja.

Os resultados da digestibilidade aparente da $\mathrm{MO}$ no trato digestivo total do atual experimento está de acordo com os de Milton et al. (1997a) em novilhos e Ferrell et al. (2001) em ovinos, quando suplementaram dietas de alta proporção de grãos com farelo de soja comparado a uréia. Contudo, discordam dos de Knaus et al. (2001), onde observaram uma maior digestibilidade da $\mathrm{MO}$ no tratamento com farelo de soja, quando comparado a uréia (75,4 e 71,5\%, respectivamente), em uma dieta de alto teor de grãos.

\subsubsection{Fibra detergente neutro e Fibra detergente ácido}

Os dados de consumo e digestibilidade aparente da Fibra detergente neutro (FDN) e Fibra detergente ácido (FDA) no trato digestivo total estão apresentados na Tabela 6.

As dietas foram isofibrosas (Tabela 4), porém, devido a redução no consumo de MS no tratamento FS (Tabela 5), promoveu uma redução $(P<0,05)$ no consumo de fibra (FDN e FDA) neste tratamento.

A digestibilidade aparente em porcentagem da FDN foi inferior $(P<0,05)$ no tratamento com farelo de soja, onde se obteve 15,6 e 14,9 unidades percentuais $(23,2 \%$ e $22,4 \%)$ inferiores aos tratamentos com uréia e amiréia, respectivamente (Tabela 6). Esta menor digestibilidade da FDN no tratamento com farelo de soja (deficiente em PDR) pode ter sido devido à falta de amônia ruminal, prejudicando as bactérias fermentadoras de fibra, as quais utilizam amônia como única fonte de nitrogênio e, por conseguinte, a redução 
da digestibilidade da fibra reduzindo a taxa de passagem e, conseqüentemente, o consumo de MS (Russel et al., 1992 e Tedeschi et al., 2000). Isso foi observado neste experimento (Tabela 5) apenas no tratamento com farelo de soja.

Silva et al. (2002), utilizando fontes nitrogenadas (farelo de soja, amiréia e farinha de subprodutos de abatedouro avícola) em novilhos confinados, não observaram diferenças na digestibilidade da FDN e FDA, discordando dos resultados do atual experimento.

Tabela 6. Consumo e digestibilidade aparente da fibra detergente neutro (FDN) e fibra detergente ácido (FDA) no trato digestivo total em bovinos de corte suplementados com fontes nitrogenadas.

\begin{tabular}{|c|c|c|c|c|c|}
\hline \multirow{2}{*}{ Itens $^{1}$} & \multicolumn{3}{|c|}{ Tratamentos $^{2}$} & \multirow[b]{2}{*}{$\mathrm{EPM}^{3}$} & \multirow[b]{2}{*}{$\mathrm{P}^{4}$} \\
\hline & FS & Uréia & A-150S & & \\
\hline \multicolumn{6}{|c|}{ Fibra detergente neutro } \\
\hline Consumo, kg/d & $2,16^{b}$ & $3,07^{a}$ & $3,03^{a}$ & 0,11 & 0,0014 \\
\hline CFDND, $\mathrm{kg} / \mathrm{d}$ & $1,11^{\mathrm{b}}$ & $2,06^{\mathrm{a}}$ & $2,01^{\mathrm{a}}$ & 0,10 & 0,0014 \\
\hline DATT, $\%$ & $51,6^{\mathrm{b}}$ & $67,2^{a}$ & $66,5^{\mathrm{a}}$ & 1,82 & 0,0209 \\
\hline \multicolumn{6}{|c|}{ Fibra detergente ácido } \\
\hline Consumo, kg/d & $1,60^{\mathrm{b}}$ & $2,30^{\mathrm{a}}$ & $2,28^{a}$ & 0,09 & 0,0022 \\
\hline CFDAD, $\mathrm{kg} / \mathrm{d}$ & $0,92^{b}$ & $1,64^{a}$ & $1,62^{\mathrm{a}}$ & 0,08 & 0,0023 \\
\hline DATT, $\%$ & $57,6^{\mathrm{b}}$ & $71,4^{\mathrm{a}}$ & $71,0^{\mathrm{a}}$ & 1,60 & 0,0283 \\
\hline
\end{tabular}

$\overline{a, b=L e t r a s ~ d i f e r e n t e s ~ n a s ~ l i n h a s ~ r e f e r e m-s e ~ a s ~ m e ́ d i a s ~ q u e ~ d i f e r e m ~ e n t r e ~ s i ~ p e l o ~ t e s t e ~ T u k e y ~}(\mathrm{P}<0,05)$; as médias foram ajustadas pelos quadrados mínimos (LSMEANS);

1 CFDND=consumo de fibra detergente neutro digestível; DATT=digestibilidade aparente no trato digestivo total; CFDAD=consumo de fibra detergente ácido digestível;

${ }^{2} \mathrm{FS}=$ farelo de soja; $\mathrm{A}-150 \mathrm{~S}=$ amiréia;

${ }^{3}$ EPM=Erro padrão da média;

${ }^{4} \mathrm{P}=$ Probabilidade de haver efeito significativo entre tratamentos.

Trabalhando com vacas leiteiras, Carmo (2001) observou resultados diferentes aos do atual experimento, quando se utilizou os mesmos 
tratamentos e não foi observado alterações na digestibilidade da FDN. Discordou-se também dos dados apresentados por Ezequiel et al. (2001a), onde a uréia apresentou uma menor digestibilidade da FDN, quando comparado ao farelo de algodão e amiréia (39,6; 50,0 e 55,7\%, respectivamente), porém trabalhando com ovinos.

A digestibilidade aparente (em porcentagem) da FDA foi reduzida $(P<0,05)$ no tratamento com farelo de soja (deficiente em PDR), onde se obteve 13,8 e 13,4 unidades percentuais (19,3\% e 18,9\%) inferiores aos tratamentos com uréia e amiréia, respectivamente (Tabela 6). Entretanto, Jones et al. (1974) e Carmo (2001) não observaram diferença na digestibilidade da FDA em vacas leiteiras, sob os mesmos tratamentos. Já Ezequiel et al. (2001b) observaram uma maior digestibilidade in vitro da FDA para o tratamento com uréia quando comparado ao farelo de algodão e amiréia.

Dietas com alta proporção de grãos, quando suplementadas com farelo de soja ou uréia (Knaus et al., 2001), não apresentaram diferença na digestibilidade da FDN (46,7 e 37,4\%, respectivamente) e FDA (54,5 e 45,7\%, respectivamente), discordando dos resultados observados no atual experimento. Os mesmos autores observaram uma maior porcentagem de digestibilidade da FDA em relação a FDN, embora os valores sejam numericamente inferiores aos aqui observados.

\subsubsection{Carboidratos não fibrosos e Proteína bruta}

Os dados de consumo e digestibilidade aparente dos carboidratos não fibrosos (CNF) e proteína bruta $(\mathrm{PB})$ no trato digestivo total estão apresentados na Tabela 7.

São raros os trabalhos que avaliam a digestibilidade dos CNF em bovinos de corte suplementados com farelo de soja, uréia e amiréia. Porém, no 
presente experimento, não foram observadas alterações entre os coeficientes de digestibilidade aparente no trato digestivo total dos $C N F(P>0,10)$.

Resultado similar foi obtido por Silva et al. (1994) na digestibilidade do extrativo não nitrogenado (ENN), quando utilizaram uréia, amiréia e farelo de soja em ovinos.

Tabela 7. Consumo e digestibilidade aparente dos carboidratos não fibrosos (CNF) e proteína bruta (PB) no trato digestivo total em bovinos de corte suplementados com fontes nitrogenadas.

\begin{tabular}{|c|c|c|c|c|c|}
\hline \multirow{2}{*}{ Itens $^{1}$} & \multicolumn{3}{|c|}{ Tratamentos $^{2}$} & \multirow{2}{*}{$\mathrm{EPM}^{3}$} & \multirow{2}{*}{$\mathrm{P}^{4}$} \\
\hline & FS & Uréia & $A-150 S$ & & \\
\hline \multicolumn{6}{|c|}{ Carboidratos não fibrosos ${ }^{5}$} \\
\hline Consumo, $\mathrm{kg} / \mathrm{d}$ & 2,51 & 3,01 & 3,07 & 0,24 & 0,3640 \\
\hline CCNFD, $\mathrm{kg} / \mathrm{d}$ & 2,22 & 2,72 & 2,75 & 0,24 & 0,4231 \\
\hline DATT, $\%$ & 88,6 & 90,4 & 89,4 & 1,20 & 0,6135 \\
\hline \multicolumn{6}{|c|}{ Proteína bruta } \\
\hline Consumo, kg/d & 0,79 & 1,00 & 0,99 & 0,07 & 0,1244 \\
\hline CPBD, $\mathrm{kg} / \mathrm{d}$ & $0,61^{d}$ & $0,84^{c}$ & $0,83^{\mathrm{C}}$ & 0,07 & 0,0929 \\
\hline DATT, $\%$ & $76,8^{d}$ & $84,1^{\mathrm{c}}$ & $83,7^{\mathrm{c}}$ & 1,16 & 0,0518 \\
\hline 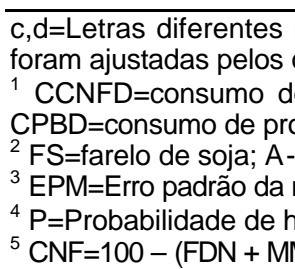 & $\begin{array}{l}\text { tos fib } \\
\text { digest } \\
\text { ia; }\end{array}$ & $\begin{array}{l}\text { dias } \\
\text { dS); }\end{array}$ & entre & este $T i$ & $<0,10) ;$ as \\
\hline
\end{tabular}

Discordando destes resultados, Knaus et al. (2001) observaram uma redução na digestibilidade dos carboidratos não estruturais (CNE), quando suplementaram novilhos com uréia comparado-os aos suplementados com 
farelo de soja ( 88,8 e $94,0 \%$, respectivamente), os quais receberam dietas com alto teor de grãos, demonstrando que o valor da digestibilidade dos CNE das dietas contendo uréia foi semelhante aos observados neste experimento.

A digestibilidade aparente no trato digestivo total da PB não diferiu $(P>0,05)$ entre os tratamentos, apresentou apenas uma tendência $(P<0,10)$ de uma maior digestibilidade $(\%$ e $\mathrm{kg} / \mathrm{d})$ nos tratamentos com nitrogênio não protéico (uréia e amiréia).

Resultados similares aos da digestibilidade da PB foram observados por Jones et al. (1975), Teller et al. (1982) e Carmo (2001) todos em vacas leiteiras e Silva et al. (1994) em ovinos, quando utilizaram as mesmas fontes nitrogenadas do atual experimento.

Salman et al. (1997) também não observaram diferenças na digestibilidade da PB em ovinos suplementados com uréia, amiréia e farelo de algodão, mas, Ezequiel et al. (2001b), utilizando dietas idênticas ao experimento anterior (Salman et al., 1997), observaram uma maior digestibilidade in vitro no tratamento com uréia.

Knaus et al. (2001) utilizando novilhos e Ferrell et al. (2001) utilizando ovinos, ambos experimentos com dietas de alto teor de grãos suplementados com uréia e farelo de soja, não observaram diferenças na digestibilidade da PB.

O mesmo foi observado em ovinos por Shiehzadeh \& Harbers (1974), em bovinos jovens por Morrill \& Dayton (1974) e em novilhos confinados por Silva et al. (2002), quando compararam farelo de soja e amiréia. Observando esses resultados citados acima pode-se inferir que dificilmente obtém-se alterações na DATT da PB quando se utiliza FS, uréia ou amiréia, confirmando os resultados do atual experimento (Tabela 7). 


\subsubsection{Nutrientes digestíveis totais e Extrato etéreo}

Os dados de consumo e digestibilidade aparente do Extrato etéreo (EE) no trato digestivo total e os valores dos Nutrientes digestíveis totais (NDT) estão apresentados na Tabela 8.

A suplementação com fontes nitrogenadas não diferiu 0 coeficiente de digestibilidade aparente do $E E(P>0,10)$, talvez devido ao baixo teor de EE nas dietas (Tabela 4), o qual ficou diluído na gordura fecal endógena. No entanto, Silva et al. (1994) observaram um coeficiente de digestibilidade do EE menor no tratamento com farelo de soja, quando comparado a uréia e amiréia, em ovinos. São raros os trabalhos que avaliam a digestibilidade do EE em bovinos de corte suplementados com farelo de soja, uréia e amiréia.

Houve uma redução $(P<0,05)$ no consumo $(\mathrm{kg} / \mathrm{d})$ de NDT no tratamento com farelo de soja, mas a porcentagem de NDT, bem como a ELm e ELg (Mcal $/ \mathrm{kg})$ não diferiram $(P>0,10)$ entre os tratamentos, demonstrando que a concentração energética das dietas foram semelhantes.

O menor consumo de NDT no tratamento com farelo de soja é, provavelmente, devido ao menor consumo de MS (Tabela 5), já que as dietas apresentavam concentrações energéticas similares (Tabela 8). Utilizando o consumo de NDT corrigido (covariável) pelo consumo de MS (6,6; 6,7 e 6,7 kg/d para os tratamentos farelo de soja, uréia e amiréia, respectivamente) não houve efeito $(P>0,05)$, reforçando o indicativo de que o principal fator foi o consumo de MS. 
Tabela 8. Consumo e digestibilidade aparente do Extrato etéreo (EE) no trato digestivo total e os valores dos Nutrientes digestíveis totais (NDT) em bovinos de corte suplementados com fontes nitrogenadas.

\begin{tabular}{|c|c|c|c|c|c|}
\hline \multirow{2}{*}{ Itens $^{1}$} & \multicolumn{3}{|c|}{ Tratamentos $^{2}$} & \multirow{2}{*}{$\mathrm{EPM}^{3}$} & \multirow{2}{*}{$\mathrm{P}^{4}$} \\
\hline & FS & Uréia & A-150S & & \\
\hline \multicolumn{6}{|c|}{ Extrato etéreo } \\
\hline Consumo, kg/d & 0,14 & 0,18 & 0,17 & 0.01 & 0,2373 \\
\hline CEED, $\mathrm{kg} / \mathrm{d}$ & 0,09 & 0,13 & 0,13 & 0,01 & 0,1709 \\
\hline DATT, \% & 66,1 & 73,8 & 76,1 & 2,05 & 0,2726 \\
\hline \multicolumn{6}{|c|}{ Nutrientes digestíveis totais ${ }^{5}$} \\
\hline Consumo, kg/d & $4,43^{b}$ & $6,20^{\mathrm{a}}$ & $6,20^{\mathrm{a}}$ & 0,37 & 0,0468 \\
\hline NDT, \% & 75,8 & 82,2 & 82,2 & 1,37 & 0,1218 \\
\hline ELm, Mcal/kg & 1,81 & 2,00 & 2,00 & 0,04 & 0,1258 \\
\hline ELg, Mcal/kg & 1,18 & 1,35 & 1,35 & 0,04 & 0,2039 \\
\hline
\end{tabular}

Ezequiel et al. (2001a) observaram resultados similares no coeficiente de digestibilidade da energia em ovinos alimentados com farelo de algodão, uréia e amiréia (64,4; 63,0 e 67,7\%, respectivamente). Os valores são menores aos do atual experimento, talvez, devido ao maior teor de volumoso (63\%) ou a espécie animal. Entretanto, Ferrell et al. (2001), utilizando dietas com alto teor de concentrado (95\%) na alimentação de ovinos, observaram um maior coeficiente de digestibilidade aparente da energia para o tratamento com farelo de soja comparado a uréia (83,7 e $80,9 \%$, respectivamente), embora o 
consumo de energia (kcal/d) não diferiu entre farelo de soja e uréia $(4,5$ e 4,1 $\mathrm{kcal} / \mathrm{d}$, respectivamente).

\subsubsection{Parâmetros ruminais}

\subsubsection{1 pH do fluido ruminal}

Os valores de $\mathrm{pH}$ no fluido ruminal para os tratamentos nos vários horários de colheita estão apresentados na Tabela 9 e Figura 2.

Não houve efeito de tratamento e da interação tratamento $x$ horários $(P>0,05)$ nos valores de $\mathrm{pH}$ do fluido ruminal, tendo apenas um efeito de horários $(\mathrm{P}<0,05)$. A variação do $\mathrm{pH}$ durante o dia seguiu a curva de fermentação padrão (Figura 2), apresentando valores inferiores $(P<0,05$ para FS e Uréia; $P<0,10$ para amiréia) duas horas após o fornecimento das rações, quando ocorre uma fermentação intensa de carboidratos rapidamente fermentescíveis, promovendo uma grande produção de ácidos e queda do $\mathrm{pH}$, o qual vai aumentando até atingir o valor máximo no momento do fornecimento (hora zero) das rações. Os valores de pH estão de acordo com Owens \& Goetsch (1988), os quais sugeriram que o pH alcança os menores valores entre meia hora e quatro horas após a alimentação.

Os resultados do presente experimento são similares aos de Thompson et al. (1972), quando suplementaram novilhos com farelo de soja, uréia e amiréia. O mesmo foi observado por Stiles et al. (1975a), entre uréia e amiréia e Shiehzadeh \& Harbers (1974), entre farelo de soja e amiréia. No entanto, Roman-Ponce et al. (1975) verificaram pH superior no tratamento com uréia duas horas após a alimentação, quando compararam com farelo de soja ou amiréia em vacas lactantes. 
Tabela 9. Valores de pH no fluido ruminal em bovinos de corte suplementados com fontes nitrogenadas.

\begin{tabular}{|c|c|c|c|c|}
\hline \multirow{2}{*}{ Horas $^{2}$} & \multicolumn{3}{|c|}{ Tratamentos $^{1}$} & \multirow{2}{*}{ Subparcelas $^{3}$} \\
\hline & FS & Uréia & A-150S & \\
\hline 0 & $6,69^{a}$ & $6,68^{a}$ & $6,71^{d}$ & $6,69^{a}$ \\
\hline 2 & $6,42^{b}$ & $6,43^{b}$ & $6,54^{\mathrm{e}}$ & $6,46^{c}$ \\
\hline 4 & $6,55^{a b}$ & $6,55^{a b}$ & $6,56^{\text {de }}$ & $6,55^{\mathrm{bc}}$ \\
\hline 6 & $6,53^{a b}$ & $6,51^{a b}$ & $6,64^{\mathrm{de}}$ & $6,56^{b c}$ \\
\hline 8 & $6,67^{a}$ & $6,58^{a b}$ & $6,60^{\text {de }}$ & $6,62^{a b}$ \\
\hline 10 & $6,64^{a}$ & $6,66^{a}$ & $6,71^{\mathrm{de}}$ & $6,67^{a}$ \\
\hline Parcelas $^{4}$ & 6,58 & 6,57 & 6,63 & \\
\hline $\begin{array}{l}\text { a,b,c=Letras dife } \\
\text { d,e }=(P<0,0) ; 0 \text { as } n \\
1 \mathrm{FS}=\text { farelo de soj } \\
2 \text { Horas após a alin } \\
{ }^{3} \text { Média das subpo } \\
{ }^{4} \text { Média das parcel }\end{array}$ & $\begin{array}{l}\text { Olunas 1 } \\
\text { ajustadas } \\
\text { niréia; } \\
\text { ); } \\
\text { os). }\end{array}$ & $\begin{array}{l}\text { média } \\
\text { os míni }\end{array}$ & $\begin{array}{l}\text { nentre si } \\
\text { vS); }\end{array}$ & te Tukey $(P<0,05)$ e \\
\hline
\end{tabular}

Milton et al. (1997b) e Shain et al. (1998) não observaram alterações no $\mathrm{pH}$ do fluido ruminal de bovinos de corte, quando aumentaram o teor de proteína e sua degradabilidade (aumentando uréia) em dietas com alta proporção de grãos, principalmente milho. No atual experimento, o aumento da degradabilidade (uréia e amiréia) não alterou o pH. São vários os fatores que alteram o valor do $\mathrm{pH}$, tais como: produção de AGV, taxa de absorção dos AGV, fluxo de água ruminal, fluxo de saliva, taxa de passagem e acidez do alimento (Erdman, 1988).

A média dos valores de $\mathrm{pH}$ não reflete bem as condições ruminais, mas sim, o quanto o $\mathrm{pH}$ ficou abaixo de 6 ou quanto o $\mathrm{pH}$ se desviou de 6 (Allen, 1996). O pH menor que 6,2 resulta em uma redução linear ra produção de proteína microbiana e digestibilidade dos carboidratos fibrosos (Pitt et al., 1996). No atual experimento, não foram observados valores de $\mathrm{pH}$ inferiores a 6,4, apesar do alto teor (80\%) de concentrado nas dietas (Tabela 4), 
indicando que $20 \%$ de volumoso na forma de BIN, tamponante, ionóforo juntamente com uma fonte de fibra de alta degradação (polpa de citros) foram suficientes para manter um ambiente ruminal estável, não prejudicando o desenvolvimento de microrganismos celulolíticos, os quais são prejudicados em pH menor que 6,5 (Owens \& Goetsch, 1988).

\section{$\mathrm{pH}$ do fluido ruminal}

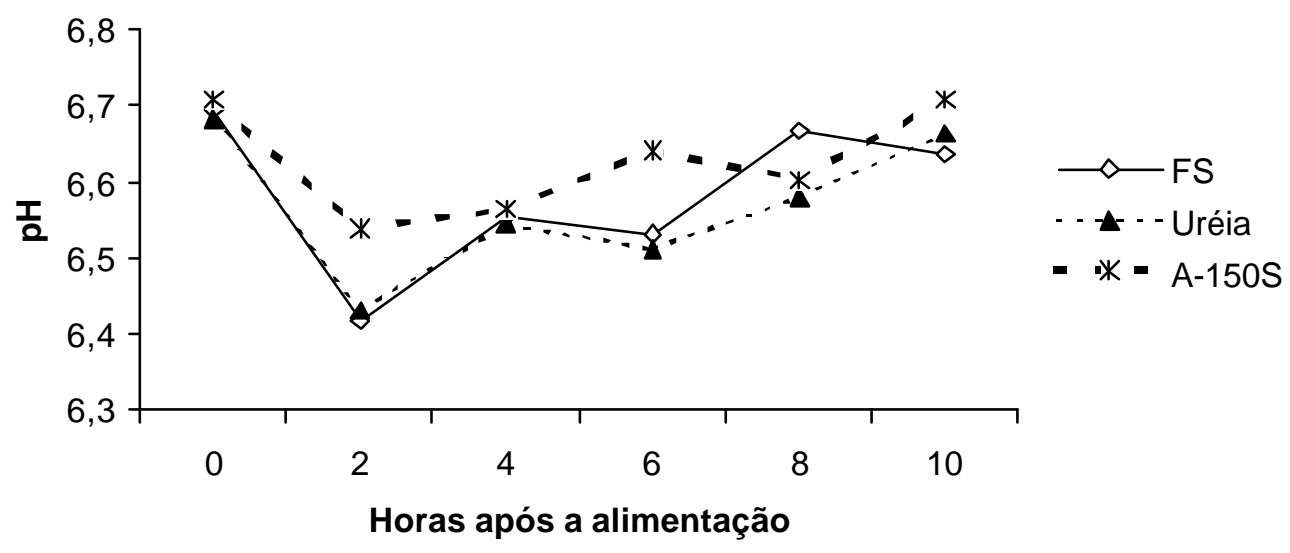

Figura 2 - Valores de pH no fluido ruminal, nos horários de colheita, em bovinos de corte suplementados com fontes nitrogenadas.

\subsubsection{Concentração molar dos ácidos graxos voláteis no rúmen}

\subsubsection{1 Ácidos graxos voláteis totais}

Os valores dos ácidos graxos voláteis totais no fluido ruminal para os tratamentos nos vários horários de colheita estão apresentados na Tabela 10. A Figura 3 ilustra o comportamento da concentração molar dos ácidos graxos voláteis totais no fluido ruminal. 
Não houve diferença $(P>0,05)$ na concentração molar de ácidos graxos voláteis totais nos valores médios diários de cada tratamento (parcelas) e na interação tratamento $x$ horários. No entanto, houve diferença $(P<0,05)$ nos valores médios dos tratamentos na variação durante 0 dia e em cada tratamento (subparcelas).

Resultado similar foi observado por Carmo (2001), utilizando as mesmas fontes nitrogenadas do atual experimento em vacas leiteiras. O mesmo foi observado por Devant et al. (2001), que comparou farelo de soja e uréia em novilhas. Entretanto, Roman-Ponce et al. (1975) observaram uma menor concentração molar de ácido graxos voláteis totais em vacas lactantes suplementadas com uréia em relação ao farelo de soja e amiréia.

Tabela 10. Concentração molar dos ácidos graxos voláteis totais no fluido ruminal (mM) em bovinos de corte suplementados com fontes nitrogenadas.

\begin{tabular}{|c|c|c|c|c|}
\hline \multirow{2}{*}{ Horas $^{2}$} & \multicolumn{3}{|c|}{ Tratamentos $^{1}$} & \multirow{2}{*}{ Subparcelas ${ }^{3}$} \\
\hline & FS & Uréia & $A-150 S$ & \\
\hline 0 & $110,9^{\mathrm{ab}}$ & $103,0^{b}$ & $93,4^{c}$ & $102,4^{b}$ \\
\hline 2 & $113,4^{\mathrm{ab}}$ & $124,6^{\mathrm{a}}$ & $118,6^{\mathrm{a}}$ & $118,9^{a}$ \\
\hline 4 & $113,5^{\mathrm{ab}}$ & $117,1^{\mathrm{ab}}$ & $113,7^{a b}$ & $114,8^{a}$ \\
\hline 6 & $120,4^{\mathrm{a}}$ & $114,9^{\mathrm{ab}}$ & $100,7^{b c}$ & $112,0^{\mathrm{a}}$ \\
\hline 8 & $111,7^{\mathrm{ab}}$ & $118,2^{\mathrm{ab}}$ & $108,4^{\mathrm{abc}}$ & $112,8^{a}$ \\
\hline 10 & $97,0^{\mathrm{b}}$ & $111,9^{\mathrm{ab}}$ & $99,5^{b c}$ & $102,8^{b}$ \\
\hline Parcelas ${ }^{4}$ & 111,2 & 115,0 & 105,7 & \\
\hline
\end{tabular}


Os microrganismos ruminais fermentam os carboidratos a AGV. A maioria dos AGV absorvidos pelo animal são utilizados (metabolizados) para produção de energia para manutenção, síntese de tecidos e leite. A concentração molar de AGV totais reflete a degradação ruminal dos carboidratos. As proporções molares dos AGV (acetato, propionato e butirato) refletem o substrato fermentado (carboidratos de rápida degradação promovem a produção de propionato e carboidratos de lenta degradação (fibra) promovem acetato). É necessário $\mathrm{N}$ ruminal disponível para que não haja limitação na degradação ruminal de carboidratos. Portanto, em dietas com carboidratos semelhantes (Tabela 4), espera-se alterações na concentração molar e proporção de AGV, somente se houver deficiência ruminal de $\mathrm{N}$ (Nocek \& Tamminga, 1991 e Mertens, 1992).

\section{Ácidos graxos voláteis totais}

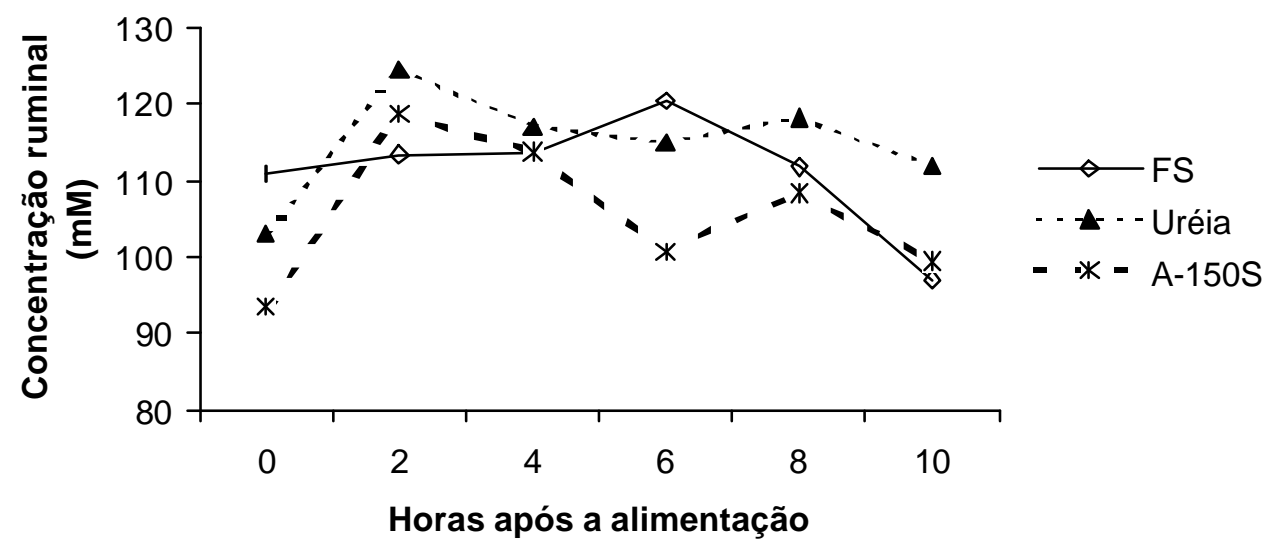

Figura 3 - Concentração molar dos ácidos graxos voláteis totais no fluido ruminal, nos horários de colheita, em bovinos de corte suplementados com fontes nitrogenadas.

Com base na concentração molar dos AGV totais do atual experimento, pôde-se concluir que não houve limitação de $\mathrm{N}$ ruminal, embora $\mathrm{o}$ 
tratamento com farelo de soja tenha apresentado uma menor concentração de nitrogênio amoniacal (Tabela 16) e um balanço ruminal de $\mathrm{N}$ negativo (NRC, 1996 e Fox et al., 2000), demonstrando que este dado (AGV) não deve ser utilizado isoladamente.

\subsubsection{2 Ácido acético}

Os valores de acetato no fluido ruminal para os tratamentos nos vários horários de colheita estão apresentados na Tabela 11 e Figura 4.

Não houve diferença $(P>0,05)$ nos valores médios de acetato dos tratamentos (parcelas) e na interação tratamento $x$ horários e na variação durante o dia (subparcelas) no tratamento de farelo de soja. Os valores médios na variação durante o dia (subparcelas) e dos tratamentos com uréia e amiréia apresentaram diferenças $(P<0,05)$.

O balanço positivo de $\mathrm{N}$ ruminal (NRC, 1996 e Fox et al., 2000), evidenciado pelo maior consumo e digestibilidade ( $\mathrm{kg} / \mathrm{d}$ e \%) de FDN e FDA (Tabela 6), pode ter sido responsável pela maior proporção de acetato, duas horas após a alimentação em relação a hora zero nos tratamentos com fonte de nitrogênio não protéico (uréia e amiréia), como pode ser visualizado na Figura 4.

Era esperado uma maior concentração molar de acetato no fluido ruminal nos tratamentos com nitrogênio não protéico (uréia e amiréia), pois estes apresentaram um maior consumo de fibra (Tabela 6). Resultado similar foi observado por Thompson et al. (1972) em novilhos e por Carmo (2001) em vacas leiteiras, quando utilizaram as mesmas fontes nitrogenadas do atual experimento. O mesmo foi observado por Devant et al. (2001) em novilhas, comparando farelo de soja e uréia. Entretanto, Roman-Ponce et al. (1975) observaram uma maior concentração molar de acetato com uréia em relação ao farelo de soja e amiréia, em vacas lactantes. 
Tabela 11. Concentração molar de acetato no fluido ruminal (mM) em bovinos de corte suplementados com fontes nitrogenadas.

\begin{tabular}{ccccc}
\hline Horas $^{2}$ & \multicolumn{3}{c}{ Tratamentos $^{1}$} & \multirow{2}{*}{ Subparcelas $^{3}$} \\
\cline { 2 - 4 } & FS & Uréia & A-150S & \\
\hline 0 & 73,6 & $73,6^{\mathrm{b}}$ & $66,4^{\mathrm{b}}$ & $71,2^{\mathrm{b}}$ \\
2 & 74,5 & $86,4^{\mathrm{a}}$ & $82,0^{\mathrm{a}}$ & $81,0^{\mathrm{a}}$ \\
4 & 75,7 & $82,1^{\mathrm{ab}}$ & $80,1^{\mathrm{a}}$ & $79,3^{\mathrm{a}}$ \\
6 & 82,7 & $80,9^{\mathrm{ab}}$ & $70,6^{\mathrm{ab}}$ & $78,1^{\mathrm{a}}$ \\
8 & 75,3 & $84,2^{\mathrm{ab}}$ & $77,8^{\mathrm{ab}}$ & $79,1^{\mathrm{a}}$ \\
10 & 65,0 & $79,7^{\mathrm{ab}}$ & $70,8^{\mathrm{ab}}$ & $71,8^{\mathrm{b}}$ \\
Parcelas $^{4}$ & 74,5 & 81,1 & 74,6 & \\
\hline
\end{tabular}

$\overline{a, b=L e t r a s ~ d i f e r e n t e s ~ n a s ~ c o l u n a s ~ r e f e r e m-s e ~ a s ~ m e ́ d i a s ~ q u e ~ d i f e r e m ~ e n t r e ~ s i ~ p e l o ~ t e s t e ~ T u k e y ~}(\mathrm{P}<0,05) ;$ as médias foram ajustadas pelos quadrados mínimos (LSMEANS);

${ }^{1} \mathrm{FS}=$ farelo de soja; $\mathrm{A}-150 \mathrm{~S}=$ amiréia;

${ }^{2}$ Horas após a alimentação;

${ }^{3}$ Média das subparcelas (horas);

${ }^{4}$ Média das parcelas (tratamentos).

\section{Ácido acético (C2)}

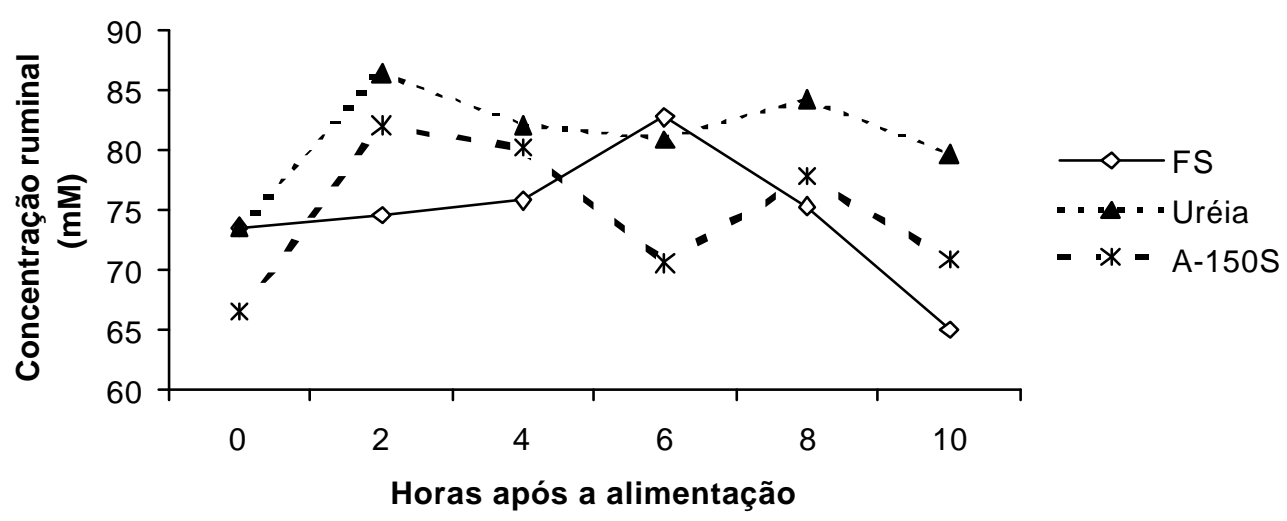

Figura 4 - Concentração molar de ácido acético no fluido ruminal, nos horários de colheita, em bovinos de corte suplementados com fontes nitrogenadas. 


\subsubsection{3 Ácido propiônico}

Os valores de propionato no fluido ruminal para os tratamentos nos vários horários de colheita estão apresentados na Tabela 12. A Figura 5 ilustra o comportamento da concentração molar de propionato no fluido ruminal, que manteve valores máximos por volta de duas horas.

Não houve diferença $(P>0,05)$ na concentração molar de propionato nos valores médios diários de cada tratamento (parcelas) e na interação tratamento $x$ horários. No entanto, houve diferença $(P<0,05)$ nos valores médios na variação durante o dia (subparcelas) e na variação durante 0 dia nos tratamentos.

Tabela 12. Concentração molar de propionato no fluido ruminal (mM) em bovinos de corte suplementados com fontes nitrogenadas.

\begin{tabular}{|c|c|c|c|c|}
\hline \multirow{2}{*}{ Horas $^{2}$} & \multicolumn{3}{|c|}{ Tratamentos $^{1}$} & \multirow{2}{*}{ Subparcelas ${ }^{3}$} \\
\hline & FS & Uréia & A-150S & \\
\hline 0 & $19,2^{\mathrm{ab}}$ & $17,3^{\mathrm{C}}$ & $14,5^{\mathrm{b}}$ & $17,0^{\mathrm{C}}$ \\
\hline 2 & $20,5^{a}$ & $23,2^{a}$ & $20,8^{a}$ & $21,5^{a}$ \\
\hline 4 & $20,1^{a}$ & $21,4^{\mathrm{ab}}$ & $19,1^{\mathrm{ab}}$ & $20,2^{a b}$ \\
\hline 6 & $20,3^{a}$ & $20,8^{a b}$ & $16,9^{b}$ & $19,3^{b}$ \\
\hline 8 & $19,4^{\mathrm{ab}}$ & $20,6^{a b}$ & $17,3^{b}$ & $19,1^{b}$ \\
\hline 10 & $16,5^{b}$ & $19,2^{b c}$ & $16,2^{b}$ & $17,3^{c}$ \\
\hline $\begin{array}{l}\text { Parcelas } \\
\text { b,c=Letras miniśsc } \\
\text { bédias foram ajustac } \\
\text { FS=farelo de soja; } \\
\text { Horas após a alime } \\
\text { Média das subparc } \\
\text { Média das parcelas }\end{array}$ & $\begin{array}{l}\frac{19,3}{\text { ntes nas ce }} \\
\text { fuadrados } \\
\text { niréia; } \\
\text { s); } \\
\text { tos) }\end{array}$ & $\frac{20,4}{\text { m-se as m m mans); }}$ & $\frac{17,5}{\text { rem entre si }}$ & este Tukey $(\mathrm{P}<0,05)$; as \\
\hline
\end{tabular}


O propionato é o precursor mais importante para a formação de glicose nos ruminantes, uma vez que a absorção de glicose no intestino dos ruminantes é insignificante (Simas, 1997), tornando importante a sua avaliação. A similaridade $(P>0,05)$ entre os tratamentos deve ter ocorrido devido ao mesmo consumo e digestibilidade dos CNF (Tabela 7), os quais são os principais precursores para a produção de propionato.

\section{Ácido propiônico (C3)}

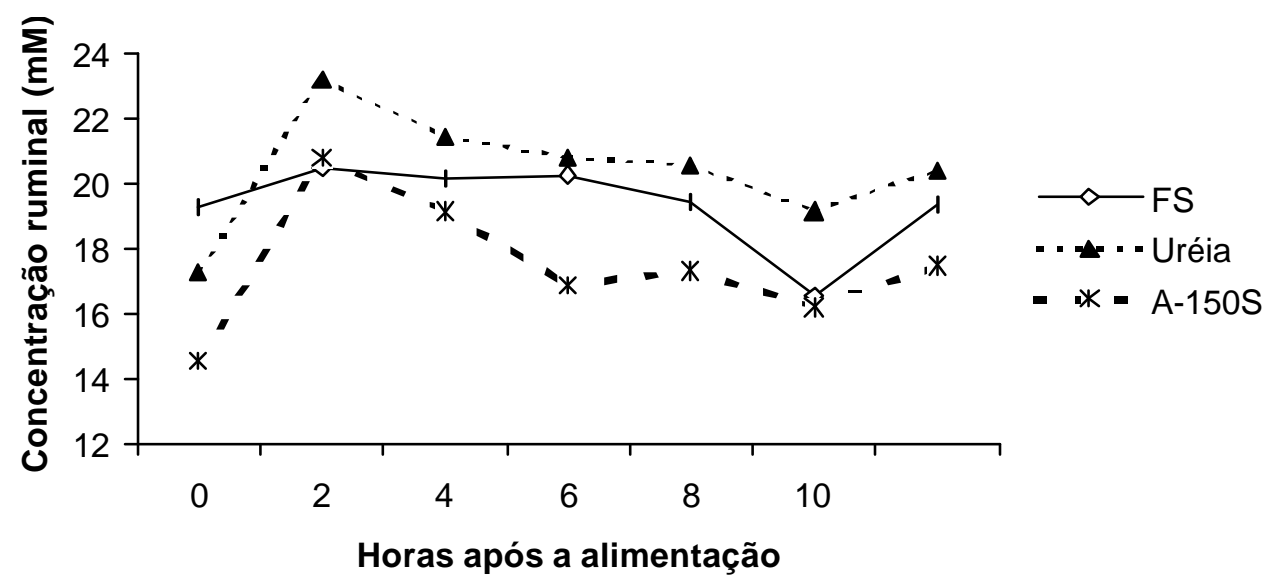

Figura 5 - Concentração molar de ácido propiônico no fluido ruminal, nos horários de colheita, em bovinos de corte suplementados com fontes nitrogenadas.

Resultado similar foi observado por Thompson et al. (1972), em novilhos e por Carmo (2001), em vacas leiteiras, quando utilizaram as mesmas fontes nitrogenadas do atual experimento. O mesmo foi observado por Devant et al. (2001), comparando farelo de soja e uréia em novilhas e por Shiehzadeh \& Harbers (1974), avaliando amiréia formada com sorgo (fonte de amido) e uréia em cordeiros. Entretanto, Roman-Ponce et al. (1975) observaram uma 
menor concentração molar de propionato com uréia em relação ao farelo de soja e amiréia, em vacas lactantes.

\subsubsection{4 Ácido butírico}

Os valores de butirato no fluido ruminal para os tratamentos nos vários horários de colheita estão apresentados na Tabela 13. A Figura 6 ilustra o comportamento da concentração molar de butirato no fluido ruminal, que manteve valores máximos por volta de duas horas para os tratamentos com uréia e amiréia e entre duas e seis horas para o tratamento com farelo de soja.

Não houve diferença $(P>0,05)$ na concentração molar de butirato nos valores médios diários de cada tratamento (parcelas) e na interação tratamento $x$ horários. No entanto, houve diferença $(P<0,05)$ nos valores médios na variação durante 0 dia e na variação durante 0 dia dentro tratamentos (subparcelas).

Resultado similar foi observado por Thompson et al. (1972) em novilhos, Roman-Ponce et al. (1975) em vacas lactantes e por Carmo (2001) em vacas leiteiras, quando utilizaram as mesmas fontes ritrogenadas do atual experimento. O mesmo foi observado por Devant et al. (2001), comparando farelo de soja e uréia em novilhas e por Shiehzadeh \& Harbers (1974), avaliando amiréia formada com sorgo (44 e $70 \%$ de equivalente protéico) e uréia em cordeiros.

Segundo Owens \& Goetsch (1988) dietas contendo principalmente forragem apresentaram uma proporção molar (moles de acetato:propionato:butirato) próxima de 65:25:10 e 50:40:10 para dietas contendo principalmente concentrado. As proporções molares (\%) observadas foram de 69,5:18,0:12,5; 71,6:18,0:10,4 e 71,9:16,8:11,3 (Tabela 11, 12 e 13) para os tratamentos com farelo de soja, uréia e amiréia, respectivamente. Embora as dietas eram de alta proporção de concentrado (80\%; Tabela 4), 
estas promoveram proporções molares similares as de dietas contendo principalmente forragem. Uma provável explicação para este fato foi a inclusão de polpa cítrica (rica em pectina) na dieta (Tabela 4), uma vez que os produtos finais da fermentação da pectina é principalmente acetato e não o propionato, o qual é favorecido em dietas ricas em amido (grãos).

Tabela 13. Concentração molar de butirato no fluido ruminal $(\mathrm{mM})$ em bovinos de corte suplementados com fontes nitrogenadas.

\begin{tabular}{|c|c|c|c|c|}
\hline \multirow{2}{*}{ Horas $^{2}$} & \multicolumn{3}{|c|}{ Tratamentos $^{1}$} & \multirow{2}{*}{ Subparcelas ${ }^{3}$} \\
\hline & FS & Uréia & A-150S & \\
\hline 0 & $13,1^{\mathrm{ab}}$ & $10,4^{b}$ & $10,5^{\mathrm{C}}$ & $11,3^{\mathrm{C}}$ \\
\hline 2 & $14,2^{a}$ & $13,1^{a}$ & $13,6^{a}$ & $13,6^{a}$ \\
\hline 4 & $13,8^{a}$ & $12,1^{a b}$ & $12,7^{\mathrm{ab}}$ & $12,9^{\mathrm{ab}}$ \\
\hline 6 & $14,3^{a}$ & $11,8^{a b}$ & $11,2^{b c}$ & $12,4^{b}$ \\
\hline 8 & $13,2^{\mathrm{ab}}$ & $12,0^{a b}$ & $11,7^{\mathrm{bc}}$ & $12,3^{b}$ \\
\hline 10 & $11,5^{\mathrm{b}}$ & $11,5^{\mathrm{ab}}$ & $10,8^{c}$ & $11,3^{\mathrm{C}}$ \\
\hline 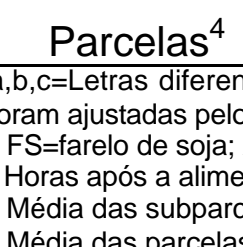 & $\begin{array}{l}13,4 \\
\text { lunas refe } \\
\text { os mínimos } \\
\text { niréia; } \\
\text { s); } \\
\text { tos }\end{array}$ & $\frac{11,8}{\text { dedias que }}$ & $\frac{11,8}{\text { si pelo tes }}$ & key $(P<0,05) ;$ as médias \\
\hline
\end{tabular}

A polpa cítrica peletizada (rica em pectina) é um carboidrato altamente degradável no rúmen e, quando comparada ao amido, promove um padrão de fermentação ruminal com maior relação acetato:propionato e uma reduzida produção de ácido lático. Essa característica é interessante quando se deseja maximizar a disponibilidade de carboidrato degradável no rúmen sem causar diminuição excessiva do pH ruminal (Van Soest, 1994). No mesmo sentido, Mendes Junior (1999) observou um aumento na proporção molar de 
acetato ruminal ao substituir parcialmente milho (moído ou floculado) por polpa de citros.

\section{Ácido butírico (C4)}

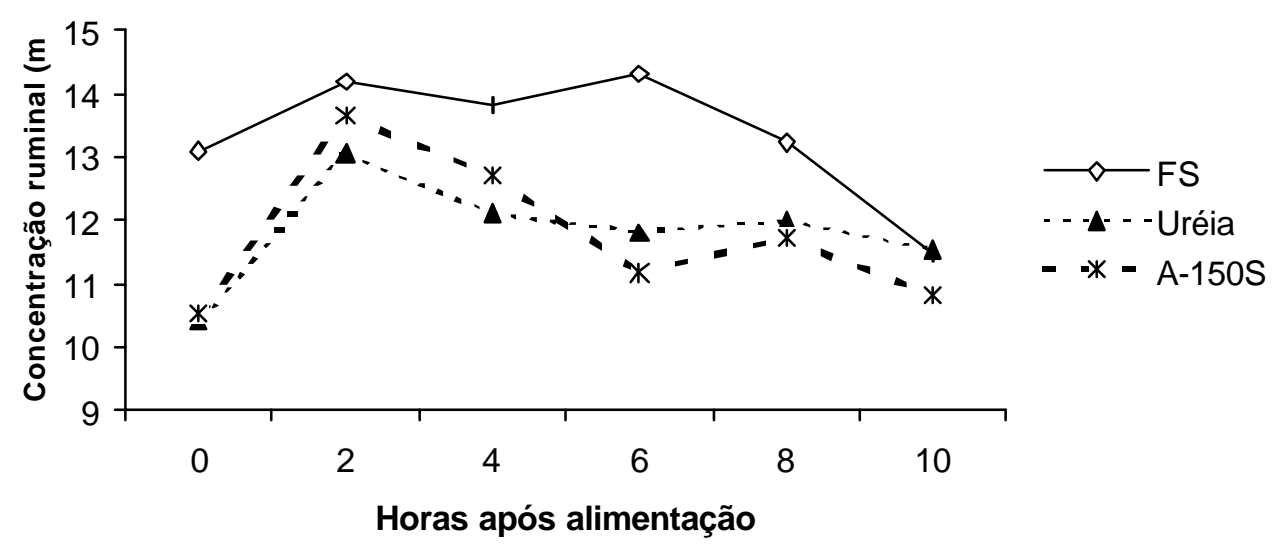

Figura 6 - Concentração molar de ácido butírico no fluido ruminal, nos horários de colheita, em bovinos de corte suplementados com fontes nitrogenadas.

\subsubsection{5 Ácidos isobutírico, valérico e isovalérico}

Os valores médios dos ácidos isobutírico, valérico e isovalérico no fluido ruminal para os tratamentos estão apresentados na Tabela 14.

$\mathrm{O}$ tratamento de farelo de soja promoveu uma maior $(\mathrm{P}<0,05)$ concentração molar dos ácidos isobutírico, valérico, isovalérico e ácidos graxos voláteis de cadeia ramificada (AGVCR) do que os tratamentos com uréia e amiréia, devido, possivelmente, ao farelo de soja, que é uma fonte de proteína verdadeira de alta degradabilidade ruminal, fornecendo aminoácidos de cadeia ramificada, os quais podem dar origem aos AGVCR. Este resultado pode ser 
também devido a uma maior síntese de proteína microbiana nas dietas com NNP (uréia e amiréia), utilizando mais os isoácidos. Nos tratamentos uréia e amiréia o CMS (Tabela 5) e a digestibilidade da fibra (FDN e FDA; Tabela 6) foram superiores, indicando uma maior síntese de proteína microbiana, o que pode ter promovido a menor concentração molar de AGVCR nestes tratamentos (Tabela 14).

Forero et al. (1980) sugeriram que, uma das razões para haver diferentes resultados nos trabalhos de pesquisa relacionados à eficiência do uso de nitrogênio não protéico (NNP) de hidrólise lenta na alimentação de ruminantes, pode estar relacionada à presença ou não de ácidos orgânicos com ramificações curtas, aminoácidos e isoácidos no rúmen. Essa hipótese também foi levantada no trabalho de revisão feito por Makkar et al. (1988).

Tabela 14. Concentração molar de isobutírato, valerato e isovalerato no fluido ruminal $(\mathrm{mM})$ em bovinos de corte suplementados com fontes nitrogenadas.

\begin{tabular}{cccc}
\hline \multirow{2}{*}{ Itens } & \multicolumn{3}{c}{ Tratamentos $^{1}$} \\
\cline { 2 - 4 } & $\mathrm{FS}$ & Uréia & $\mathrm{A}-150 \mathrm{~S}$ \\
\hline Isobutírico & $1,16^{\mathrm{A}}$ & $0,32^{\mathrm{B}}$ & $0,47^{\mathrm{B}}$ \\
Valérico & $1,21^{\mathrm{A}}$ & $0,83^{\mathrm{B}}$ & $0,77^{\mathrm{B}}$ \\
Isovalérico & $1,72^{\mathrm{A}}$ & $0,45^{\mathrm{B}}$ & $0,63^{\mathrm{B}}$ \\
AGVCR & $2,87^{\mathrm{A}}$ & $0,77^{\mathrm{B}}$ & $1,11^{\mathrm{B}}$ \\
\hline${ }^{\mathrm{A}, \mathrm{B}}=$ Letras diferentes nas linhas referem-se as médias que diferem entre si pelo teste Tukey $(\mathrm{P}<0,05) ;$ as médias foram \\
ajustadas pelos quadrados mínimos (LSMEANS); \\
${ }_{1}^{1} \mathrm{FS}=$ farelo de soja; A-150S=amiréia; \\
${ }^{2} \mathrm{AGVCR}=$ ácidos graxos de cadeia ramificada = isobutírico + isovalérico.
\end{tabular}

Os ácidos graxos voláteis de cadeias ramificadas (AGVCR: isobutírico, isovalérico e 2-metilbutírico) são derivados de fontes dietéticas ou da reciclagem de proteína microbiana. AGVCR são nutrientes essenciais para 
aumentar o crescimento das bactérias celulolíticas e algumas não celulolíticas. Após a absorção dos AGVCR pelas bactérias, eles são utilizados para sintetizar aminoácidos essenciais (valina, leucina e isoleucina) (Allison ciatdo por Tedeshi, 2001).

Prévios estudos sumarizados por Tedeshi (2001) demonstraram que os AGVCR podem aumentar o consumo, digestão da celulose, crescimento microbiano e o ganho de peso de animais em crescimento alimentados com dietas contendo principalmente forragem. Isso demonstra que, embora os AGVCR tenham valores pequenos, podem alterar o metabolismo e o desempenho dos animais.

Resultado similar na concentração molar do ácido valérico foi observado por Devant et al. (2001) entre farelo de soja e uréia, mas, não verificaram alterações na concentração molar de isobutírico, isovalérico (AGVCR). Observando os resultados do ácido valérico e isovalérico do atual experimento verifica-se uma discordância dos observados por Thompson et al. (1972), os quais utilizaram as mesmas fontes nitrogenadas na dieta de novilhos. No mesmo sentido, Stiles et al. (1970) observaram uma maior concentração de isobutírico e isovalérico no tratamento uréia mais milho moído grosso, quando comparado ao tratamento amiréia. Os autores sugeriram que este resultado ocorreu devido a maior síntese de proteína microbiana, utilizando mais os isoácidos, já que a amiréia apresenta um amido mais degradável.

\subsection{Relação Acetato/Propionato}

Os valores da relação acetato/propionato (C2/C3) no fluido ruminal para os tratamentos nos vários horários de colheita estão apresentados na Tabela 15 e Figura 7.

Não houve diferença $(P>0,05)$ nos valores médios da relação C2/C3 dos tratamentos (parcelas), na interação tratamento $x$ horários e na 
variação durante o dia (subparcelas) no tratamento de farelo de soja. Os valores médios na variação durante o dia (subparcelas) e dos tratamentos com uréia e amiréia apresentaram diferenças $(P<0,05)$.

Resultados similares foram observados por Thompson et al. (1972), em novilhos e Carmo (2001) em vacas leiteiras, quando utilizaram as mesmas fontes nitrogenadas do atual experimento. $O$ mesmo foi observado por Devant et al. (2001) em novilhas, comparando farelo de soja e uréia, com uma relação volumoso/concentrado de 12:88 e uma relação C2/C3 próxima de 1 . Entretanto Roman-Ponce et al. (1975), utilizando bagaço de cana-de-açúcar peletizado (30 e 40\% da MS) em vacas lactantes, observaram uma maior relação acetato/propionato no tratamento com uréia em relação ao farelo de soja e amiréia.

Tabela 15. Relação acetato propionato no fluido ruminal $(\mathrm{mM})$ em bovinos de corte suplementados com fontes nitrogenadas.

\begin{tabular}{|c|c|c|c|c|}
\hline \multirow[b]{2}{*}{ Horas $^{2}$} & \multicolumn{3}{|c|}{ Tratamentos $^{1}$} & \multirow[b]{2}{*}{ Subparcelas $^{3}$} \\
\hline & $\mathrm{FS}$ & Uréia & $A-150 S$ & \\
\hline 0 & 4,1 & $4,3^{a}$ & $4,6^{a}$ & $4,3^{a}$ \\
\hline 2 & 3,8 & $3,8^{c}$ & $4,0^{\mathrm{C}}$ & $3,8^{c}$ \\
\hline 4 & 3,9 & $3,9^{b c}$ & $4,2^{b c}$ & $4,0^{b c}$ \\
\hline 6 & 4,2 & $3,9^{b c}$ & $4,2^{b c}$ & $4,1^{a b}$ \\
\hline 8 & 4,0 & $4,1^{\mathrm{ab}}$ & $4,5^{a b}$ & $4,2^{a}$ \\
\hline 10 & 4,0 & $4,2^{a b}$ & $4,5^{a b}$ & $4,2^{a}$ \\
\hline Parcelas $^{4}$ & 4,0 & 4,0 & 4,3 & \\
\hline
\end{tabular}


Os valores da relação acetato/propionato no fluido ruminal atingiram seus valores mínimos por volta de duas horas após a alimentação (Figura 7), devido a maior produção de propionato neste horário (Tabela 12), possivelmente, devido a maior degradabilidade do amido neste horário. Após este horário, a degradação ruminal do amido vai diminuindo e a polpa de citros (fibra de alta digestibilidade) mantém sua degradação, promovendo o aumento da relação acetato/propionato.

\section{Relação Acetato/Propionato (C2/C3)}

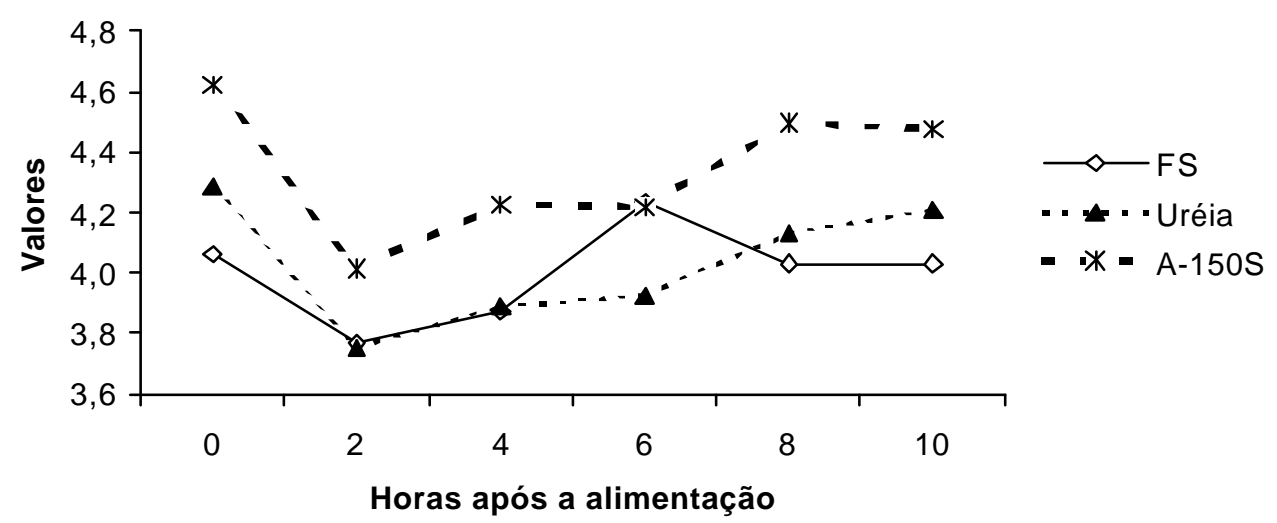

Figura 7 - Relação acetato/propionato no fluido ruminal, nos horários de colheita, em bovinos de corte suplementados com fontes nitrogenadas.

A relação acetato/propionato pode ser utilizada como um indicador de estabilidade ruminal. Segundo Eastridge (1997) a relação aceitável de C2/C3 é de 3:1 a 2,5, até possivelmente 2,2:1 para otimização ruminal. Revendo dados da literatura, Erdman (1988) demonstrou uma relação positiva entre teores de FDA e a relação C2/C3. Entretanto, Armentano \& Pereira (1997) observaram que, quando são utilizados subprodutos, estas relações são fracas, 
devido os subprodutos apresentarem um padrão de fermentação diferente dos alimentos convencionais. Essa observação de Armentano \& Pereira (1997) pode ser, de certa forma, confirmada no atual experimento, devido aos altos valores das relações C2/C3 em comparação aos demais experimentos (Thompson et al., 1972; Carmo, 2001; Devant et al., 2001 e Roman-Ponce et al., 1975).

\subsubsection{Concentração de nitrogênio amoniacal no fluido ruminal}

Os valores de nitrogênio amoniacal no fluido ruminal para os tratamentos nos vários horários de colheita estão apresentados na Tabela $16 \mathrm{e}$ Figura 8. Houve diferença $(P<0,05)$ nos valores médios de nitrogênio amoniacal entre tratamentos (parcelas) e na variação média durante o dia (subparcelas) e nos tratamentos uréia e amiréia. $A$ interação tratamento $x$ horários apresentou uma tendência $(P<0,10)$.

Os tratamentos apresentaram picos de nitrogênio amoniacal por volta de duas horas após a alimentação (Figura 8), estando o pico dos tratamentos com fonte de nitrogênio não protéico (uréia e amiréia) de acordo com Owens \& Zinn (1988); porém, o tratamento com farelo de soja deveria ter tido seu pico entre três a quatro horas segundo os mesmos autores.

No tratamento com farelo de soja os valores nos horários (subparcelas) são muito próximos, praticamente sem um pico ( $P>0,10$; Figura 8), o que pode acontecer em dietas com baixa proteína (Owens \& Zinn, 1988). No entanto, as dietas do atual experimento não são baixas em proteína total (Tabela 4), mas o tratamento com farelo de soja apresentou um balanço de nitrogênio ruminal negativo (NRC, 1996 e Fox et al., 2000), o que pode ter promovido uma redução na taxa de digestão e no consumo de matéria seca (Tabela 5), por falta de amônia para as bactérias ruminais (Owens \& Zinn, 1988). 
Tabela 16. Concentração de nitrogênio amoniacal no fluido ruminal (mg/dL) em bovinos de corte suplementados com fontes nitrogenadas.

\begin{tabular}{ccccc}
\hline Horas $^{2}$ & \multicolumn{4}{c}{ Tratamentos $^{1}$} \\
\cline { 2 - 4 } & FS & Uréia & A-150S & \\
\hline 0 & 15,0 & $15,8^{\mathrm{b}}$ & $11,3^{\mathrm{b}}$ & $17,3^{\mathrm{b}}$ \\
2 & $17,9^{\mathrm{B}}$ & $28,6^{\mathrm{Aa}}$ & $23,4^{\mathrm{ABa}}$ & $23,3^{\mathrm{a}}$ \\
4 & $12,9^{\mathrm{B}}$ & $22,6^{\mathrm{Aab}}$ & $20,1^{\mathrm{ABab}}$ & $18,5^{\mathrm{ab}}$ \\
6 & $11,8^{\mathrm{B}}$ & $22,1^{\mathrm{Aab}}$ & $17,3^{\mathrm{ABab}}$ & $17,1^{\mathrm{b}}$ \\
8 & $13,9^{\mathrm{AB}}$ & $21,0^{\mathrm{Aab}}$ & $12,3^{\mathrm{Bb}}$ & $15,7^{\mathrm{b}}$ \\
10 & 16,6 & $16,8^{\mathrm{b}}$ & $18,7^{\mathrm{ab}}$ & $17,4^{\mathrm{b}}$ \\
Parcelas $^{4}$ & $14,7^{\mathrm{A}}$ & $21,1^{\mathrm{B}}$ & $17,2^{\mathrm{AB}}$ & \\
\hline
\end{tabular}

$a, b=$ Letras diferentes nas colunas referem-se à médias que diferem entre si pelo teste Tukey $(P<0,05)$ e letras maiúsculas diferentes nas linhas referem-se æ̀ médias que diferem entre si pelo teste Tukey $(P<0,10)$; as médias foram ajustadas pelos quadrados mínimos (LSMEANS);

${ }_{1}^{1} \mathrm{FS}=$ farelo de soja; $\mathrm{A}-150 \mathrm{~S}=$ amiréia;

${ }^{2}$ Horas após a alimentação;

${ }^{3}$ Média das subparcelas (horas);

${ }^{4}$ Média das parcelas (tratamentos).

O menor $(\mathrm{P}<0,05)$ valor da concentração do nitrogênio amoniacal no fluido ruminal do tratamento com farelo de soja comparado ao de uréia provavelmente ocorreu devido a menor degradabilidade da proteína (balanço de nitrogênio ruminal negativo - NRC, 1996 e Fox et al., 2000) neste tratamento. Segundo Devant et al. (2001), em dietas com alto teor de concentrado, a degradabilidade da PB do farelo de soja diminui, limitando a disponibilidade de amônia e ácidos graxos voláteis de cadeias ramificadas. No mesmo sentido, a taxa de produção de peptídeo é reduzida em 50\% com adição de ionóforo (Russel, 1994). Com o aumento no consumo de proteína degradável, Milton et al. (1997b), Shain et al. (1998) e Fu et al. (2001) observaram um aumento linear na concentração de nitrogênio amoniacal em novilhos alimentados com dietas com altos teores de grãos. 


\section{$\mathrm{N}$ amoniacal no fluido ruminal}

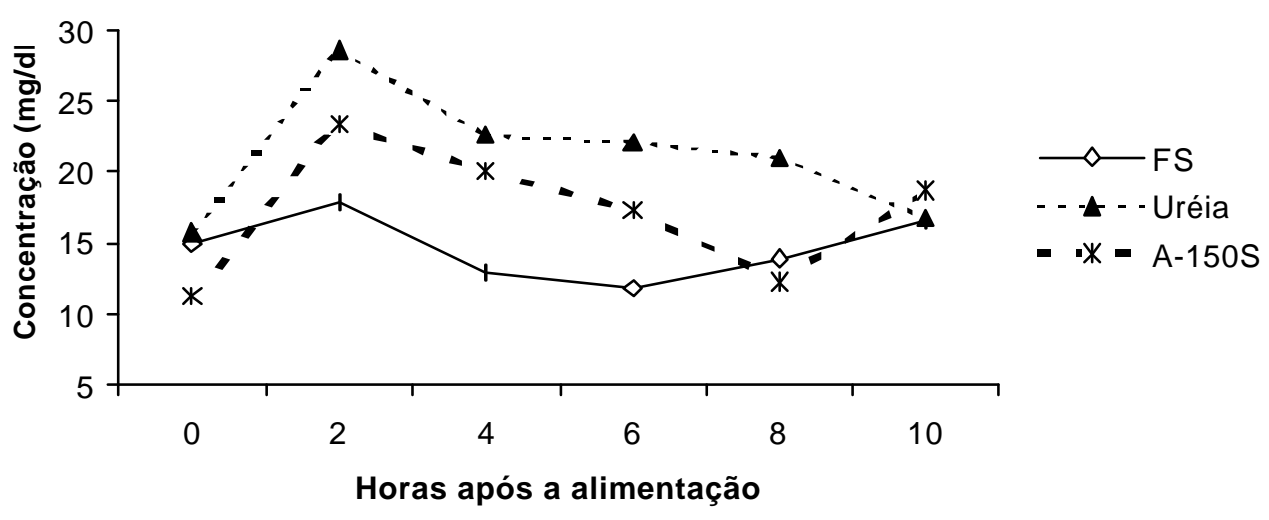

Figura 8 - Concentração de amônia no fluido ruminal, nos horários de colheita, em bovinos de corte suplementados com fontes nitrogenadas.

O tratamento com amiréia não apresentou uma diferença $(P>0,05)$ na concentração de nitrogênio amoniacal, quando comparado ao tratamento com uréia. Resultado similar foi observado por Shiehzadeh \& Harbers (1975) em ovinos. Em alguns estudos (Helmer et al., 1970b e Stiles et al., 1975a), a amiréia proporcionou menor concentração de nitrogênio amoniacal quando comparada a uréia mais milho moído, mas, quando se substitui o milho moído por extrusado, geralmente não há diferenças, indicando que a menor concentração de amônia ruminal foi devido ao processamento do grão e não, àsuposta liberação gradativa de N (Quadros 3 e 4).

A concentração de nitrogênio amoniacal no fluido ruminal parece ser resultado de um balanço entre sua utilização pelos microrganismos ruminais e a saída do rúmen através da absorção pela parede do rúmen, efeito que é dependente do $\mathrm{pH}$, ou fluxo para o duodeno junto com a digesta e a sua taxa de liberação (Chalupa, 1968). Hoover (1986) debateu extensivamente o intervalo ótimo da concentração de nitrogênio amoniacal (3,3 a 21,5 mg/dL) para síntese 
de proteína microbiana, demonstrando que é muito variável a concentração de nitrogênio amoniacal para maximizar a síntese de proteína microbiana.

Os valores da concentração de nitrogênio amoniacal do atual experimento estão dentro da faixa proposta por Hoover (1986). No entanto, no tratamento farelo de soja a concentração de amônia ruminal $(14,7 \mathrm{mg} / \mathrm{dL})$ parece que não foi suficiente para maximizar a síntese de proteína microbiana, uma vez que, neste tratamento o CMS (Tabela 5) e a digestibilidade da fibra (FDN e FDA; Tabela 6) foram inferiores, indicando uma menor síntese de proteína microbiana. Mas, os resultados do atual experimento estão de acordo com Mehrez et al. (1977), os quais observaram uma taxa de 95, 85 e 75\% de desaparecimento máximo do substrato com as concentrações de amônia ruminal de 24,19 e $15 \mathrm{mg} / \mathrm{dL}$, respectivamente.

No presente experimento, não ocorreu uma menor concentração de nitrogênio amoniacal no tratamento com amiréia quando comparado ao de uréia, talvez, devido a alta concentração de equivalente protéico $(150 \%)$ da amiréia utilizada, disponibilizando pouco amido gelatinizado para o animal, o qual não foi suficiente para diminuir a concentração de nitrogênio amoniacal (Wilson \& Woods, 1966 e 1967; Helmer et al., 1970b; Stiles et al., 1975a; Simas, 1995 e Mendes Junior, 1999).

\subsubsection{Parâmetros sanguíneos}

\subsubsection{Concentração de nitrogênio uréico no plasma (NUP) sanguíneo}

Os valores de nitrogênio uréico no plasma sanguíneo para os tratamentos nos vários horários de colheita estão apresentados na Tabela 17 e Figura 9. Não houve diferença $(P>0,05)$ nos valores médios de nitrogênio uréico dos tratamentos (parcelas). A variação durante o dia (subparcelas) e a interação tratamento x horários não apresentaram alterações $(P>0,05)$. 
Resultados similares foram observados por Jones et al. (1975) e Carmo (2001) na primeira fase do experimento, em vacas e, Fernandes (2002) na oitava semana, em cabras, quando utilizaram as mesmas fontes nitrogenadas do atual experimento. O mesmo foi observado em cordeiros por Shiehzadeh \& Harbers (1974) entre amiréia e uréia, e por Knaus et al. (2001) em novilhos em crescimento alimentados com uréia e farelo de soja, sendo os teores de PB próximos aos do atual experimento (13,7\%). Entretanto, Schmidt et al. (1973), utilizando novilhos, observaram uma menor concentração de nitrogênio uréico no tratamento de farelo de soja quando comparado aos de uréia e amiréia.

Tabela 17. Concentração de nitrogênio uréico no plasma sanguíneo (mg/dL) em bovinos de corte suplementados com fontes nitrogenadas.

\begin{tabular}{|c|c|c|c|c|}
\hline \multirow{2}{*}{ Horas $^{2}$} & \multicolumn{3}{|c|}{ Tratamentos $^{1}$} & \multirow{2}{*}{ Subparcelas ${ }^{3}$} \\
\hline & FS & Uréia & A-150S & \\
\hline \multirow{2}{*}{$\begin{array}{l}0 \\
2\end{array}$} & 20,5 & 19,2 & 17,7 & 19,1 \\
\hline & 20,8 & 16,7 & 18,5 & 18,7 \\
\hline 4 & 21,1 & 17,2 & 19,0 & 19,1 \\
\hline 6 & 21,2 & 18,7 & 19,0 & 19,6 \\
\hline 8 & 20,8 & 17,8 & 18,2 & 18,9 \\
\hline 10 & 21,0 & 17,0 & 18,4 & 18,8 \\
\hline Parcelas $^{4}$ & $20,9^{a}$ & $17,8^{a}$ & $18,5^{a}$ & \\
\hline $\begin{array}{l}\text { Letras diferente } \\
\text { tadas pelos qua } \\
\text { Sfarelo de soja; } \\
\text { rasa após a alime } \\
\text { édia das subpar } \\
\text { édia das parcela }\end{array}$ & $\begin{array}{l}\text { av referen } \\
\text { immos (LSS } \\
\text { miréia; } \\
\text { is); } \\
\text { tos). }\end{array}$ & & & 5); as médias foram \\
\hline
\end{tabular}

A uréia é sintetizada pelo fígado a partir do $\mathrm{N}^{-\mathrm{NH}_{3}}$ a qual é produzida durante o catabolismo das proteínas. O organismo gasta energia 
considerável para produzir a uréia a fim de evitar a toxicidade por $\mathrm{N}-\mathrm{NH}_{3}$ (Swenson \& Reece, 1996). Com base nessa afirmação, podemos inferir que os teores de proteína bruta das dietas estavam em excesso, já que apresentaram altas concentrações de nitrogênio uréico no plasma, tanto para o tratamento com deficiência em PDR ou para os ajustados em PDR (uréia e amiréia). As concentrações de uréia sanguínea têm sido utilizadas para monitorar o consumo de proteína dietética próximo as exigências do animal, já que o consumo excessivo de proteína pode afetar o desempenho reprodutivo do animal, aumentado sua exigência em energia ou ainda, aumentar o custo da ração (Broderick \& Clayton, 1997).

O NUP não é um bom indicador de consumo de proteína, mas pode ser um bom indicador da proteína não utilizada (Staples et al., 1993). Isso reforça a hipótese de que os animais do atual experimento não estavam sendo capazes de utilizar uma boa parte da proteína consumida, uma vez que, os valores de NUP foram altos (Tabela 17).

Staples et al. (1993) sugeriram que valores de NUP acima de 16 $\mathrm{mg} / \mathrm{dL}$ pode incidir problemas reprodutivos em vacas lactantes. Os valores do atual experimento ficaram sempre acima deste (Tabela 17), merecendo mais estudos sobre o assunto em bovinos de corte. Embora a maioria dos animais confinados são destinados ao abate, este assunto tornasse menos relevante. 


\section{$\mathrm{N}$ uréico no plasma}

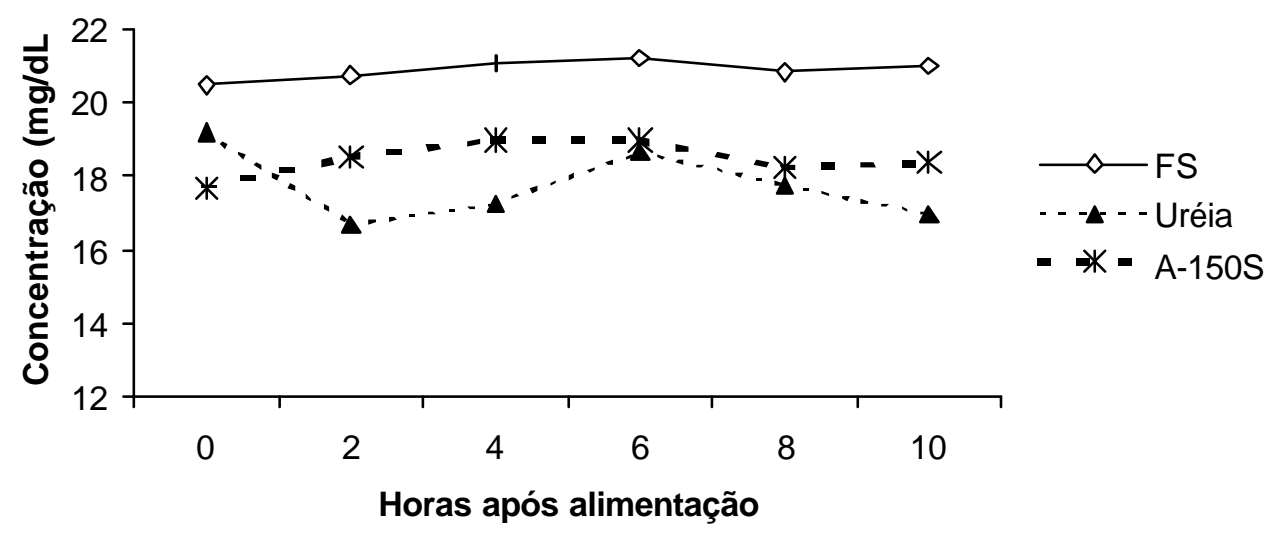

Figura 9 - Concentração de nitrogênio uréico no plasma sanguíneo, nos horários de colheita, em bovinos de corte suplementados com fontes nitrogenadas.

Staples et al. (1993) concluíram que um horário para obter um valor representativo de NUP em vacas leiteiras, esta entre 6 e 7 horas após a alimentação, observando os resultados apresentados na Tabela 17 verifica-se que, o melhor horário foi 8 horas após a alimentação, hora esta, muito próxima do intervalo proposto pelos autores, embora, não tenha sido avaliado na hora 7.

\subsubsection{Concentração de glicose no plasma sanguíneo}

Os valores de glicose no plasma sanguíneo para os tratamentos quatro horas após a alimentação estão apresentados na Tabela 18. Não houve diferença $(P>0,05)$ nos valores médios de glicose plasmática entre os tratamentos. Resultados similares foram observados em vacas leiteiras por Carmo (2001) e Fernandes (2002) em cabras leiteiras quando utilizaram as 
mesmas fontes nitrogenadas do atual experimento. O mesmo foi observado por Knaus et al. (2001) em novilhos em crescimento alimentados com uréia e farelo de soja, sendo os teores de PB próximos aos do atual experimento (13,7\%).

Tabela 18. Concentração de glicose no plasma sanguíneo em bovinos de corte suplementados com fontes nitrogenadas.

\begin{tabular}{|c|c|c|c|c|}
\hline \multirow[b]{2}{*}{ Item } & \multicolumn{3}{|c|}{ Tratamentos $^{1}$} & \multirow[b]{2}{*}{$\mathrm{EPM}^{2}$} \\
\hline & FS & Uréia & A-150S & \\
\hline Glicose, mg/dL & $62,2^{a}$ & $65,2^{a}$ & $69,8^{a}$ & 7,85 \\
\hline
\end{tabular}

Visek (1984) revisando trabalhos observou que a arginina aumenta a insulina no plasma nos testes de tolerância a glicose em ratos e, conseqüentemente, a taxa de renovação de glicose do sangue. Com base nos dados o autor sugere também que a deficiência de arginina pode levar a insulina presente na circulação a não ter efeito na circulação da glicose. Nos períodos de alta absorção de amônia, a arginina é usada no processo de desintoxicação pela síntese de uréia, podendo, portanto, não estar disponível em quantidade suficientes para potencializar a liberação e o efeito da insulina. Com base neste conhecimento pode-se inferir que as quantidades de NNP (uréia ou amiréia) utilizadas (Tabela 4) não foram prejudiciais metabolicamente para os animais, já que não diferiu a concentração de glicose entre os tratamentos (Tabela 18). 


\subsubsection{Metabolismo do nitrogênio}

Os dados de consumo de nitrogênio $(\mathrm{N}), \mathrm{N}$ nas fezes, $\mathrm{N}$ na urina, $\mathrm{N}$ retido e valor biológico da proteína das rações contendo fontes de nitrogênio estão apresentados na Tabela 19.

O menor consumo de $\mathrm{N}(\mathrm{P}<0,05)$ no tratamento com farelo de soja foi devido, provavelmente, ao menor consumo de MS (Tabela 5), já que as dietas eram isoprotéicas (Tabela 4).

O tratamento com uréia proporcionou uma maior $(\mathrm{P}<0,05)$ retenção de $\mathrm{N}$ ( $\mathrm{g} / \mathrm{d}$ ou \% do $\mathrm{N}$ consumido), que ocorreu principalmente, devido a menor excreção de $\mathrm{N}$ proporcional na urina. Calculando-se as proporções de $N$ urinário em relação ao consumo total de $N$, obtém-se os resultados de 40,9 ; 30,7 e 46,4\% para farelo de soja, uréia e amiréia, respectivamente. Ou seja, os tratamentos com farelo de soja e amiréia excretaram 10,2 e 15,7 unidades percentuais, respectivamente, mais $\mathrm{N}$ na urina proporcionalmente ao $\mathrm{N}$ consumido que o tratamento com uréia, o que levou a um maior $(P<0,05)$ valor biológico da proteína no tratamento com uréia, pois aumentou a retenção de $\mathrm{N}$ neste tratamento, uma vez que, o $N$ nas fezes não diferiu $(P>0,10)$ entre os tratamentos.

Resultado similar da retenção de $\mathrm{N}$ em porcentagem do $\mathrm{N}$ consumido foi observado por Silva et al. (1994), em ovinos alimentados com farelo de soja, uréia e amiréia. No entanto, Knaus et al. (2001) não observaram diferenças entre farelo de soja e uréia no $\mathrm{N}$ urinário $(57,5$ e $54,1 \mathrm{~g} / \mathrm{d}$, respectivamente) e no valor biológico da proteína (45,5 e 46,3\%, respectivamente), em novilhos alimentados com ração de alta proporção de concentrado. Os dados de Knaus et al. (2001), referentes ao $\mathrm{N}$ urinário e valor biológico do tratamento com farelo de soja, são similares aos do mesmo tratamento do atual experimento. 
Tabela 19. Metabolismo do nitrogênio $(\mathrm{N})$ em bovinos de corte suplementados com fontes nitrogenadas.

\begin{tabular}{lcccrc}
\hline & \multicolumn{5}{c}{ Tratamentos $^{1}$} \\
\cline { 2 - 4 } Itens & FS & Uréia & A-150S & EPM $^{2}$ & $P^{3}$ \\
\hline Consumo de N, g/d & $131,6^{\mathrm{b}}$ & $166,7^{\mathrm{a}}$ & $157,4^{\mathrm{a}}$ & 5,7 & 0,006 \\
N nas fezes, g/d & $24,1^{\mathrm{a}}$ & $28,9^{\mathrm{a}}$ & $31,0^{\mathrm{a}}$ & 2,1 & 0,114 \\
$\mathrm{~N}$ na urina, g/d & $53,8^{\mathrm{b}}$ & $51,2^{\mathrm{b}}$ & $73,1^{\mathrm{a}}$ & 5,5 & 0,044 \\
N retido, g/d & $53,7^{\mathrm{b}}$ & $86,6^{\mathrm{a}}$ & $53,2^{\mathrm{b}}$ & 6,7 & 0,011 \\
N retido, \% N consumido & $40,8^{\mathrm{b}}$ & $52,0^{\mathrm{a}}$ & $33,7^{\mathrm{b}}$ & 4,1 & 0,022 \\
Valor Biológico & & & & & \\
(N retido, \% do N digerido) & $49,8^{\mathrm{b}}$ & $62,8^{\mathrm{a}}$ & $42,1^{\mathrm{b}}$ & 4,4 & 0,015 \\
\hline
\end{tabular}

$\mathrm{a}, \mathrm{b}=$ Letras diferentes nas linhas referem-se as médias que diferem entre si pelo teste Tukey $(\mathrm{P}<0,05)$; as médias foram ajustadas pelos quadrados mínimos (LSMEANS);

${ }^{1} \mathrm{FS}=$ farelo de soja; $\mathrm{A}-150 \mathrm{~S}=$ amiréia;

2 EPM=Erro padrão da média;

${ }^{3} \mathrm{P}=$ Probabilidade de haver efeito significativo entre tratamentos.

O maior $(\mathrm{P}<0,05)$ valor biológico da proteína do tratamento com uréia quando comparado ao farelo de soja e amiréia, pode ter sido devido a uma maior síntese de proteína microbiana (maior PDR), a qual apresenta um melhor perfil de aminoácidos (Tabela 1), portanto uma maior retenção. Estes resultados estão de acordo com a afirmação de Owens \& Zinn (1988), que o sistema de reciclagem de nitrogênio no rúmen se adapta facilmente a rapidez da liberação de amônia pelas fontes de nitrogênio não protéico, desde que as concentrações não atinjam níveis tóxicos. No mesmo sentido, o balanço de nitrogênio ruminal positivo (NRC, 1996 e Fox et al., 2000), no tratamento com uréia nos dá um indicativo de maior síntese de proteína microbiana em relação ao tratamento com farelo de soja.

Estudos com dietas com alto teor de concentrado (milho) têm demonstrado que os peptídeos e/ou aminoácidos do milho devem proporcionar uma máxima síntese e eficiência de proteína microbiana (Milton et al., 1997a; 
Fu et al., 2001 e Knaus et al., 2001). O uso de uréia como a única fonte suplementar de $\mathrm{N}$ pode ser utilizada eficientemente para suprir a exigência de proteína metabolizável e aminoácidos, em dietas com alto teor de concentrado (Knaus et al., 2001), estas afirmações estão de acordo com os resultados apresentados na Tabela 18, onde se verifica uma maior retenção de $\mathrm{N}$ e valor biológico da dieta com uréia.

O menor $(\mathrm{P}<0,05)$ valor da retenção de $\mathrm{N}$ no tratamento com amiréia quando comparado ao de uréia, não apresenta uma explicação lógica, sendo a principal causa, a maior excreção de $\mathrm{N}$ na urina (21,9 unidades percentuais a mais; Tabela 19). Um fator que deve ser considerado segundo Van Soest (1994) é que produtos da reação de Maillard podem aparecer na fração solúvel da proteína e serem absorvidos, mas não são metabolizados e são excretados na urina, sendo que a maioria destes compostos passa direto pelos intestinos, saindo nas fezes. Isto pode ter acontecido devido há possibilidade de ocorrer reações de Maillard no procedimento de fabricação da amiréia.

Salman et al. (1997) observaram uma maior excreção de $\mathrm{N}$ na urina no tratamento com amiréia $(7,7 \mathrm{~g} / \mathrm{d})$ em relação ao farelo de algodão $(4,8$ $\mathrm{g} / \mathrm{d})$, sendo ambos similares a do tratamento com uréia $(6,5 \mathrm{~g} / \mathrm{d})$, em ovinos. Os mesmos autores não observaram alterações no valor biológico da proteína (73,1; 58,1 e 57,6\%, para farelo de algodão, uréia e amiréia, respectivamente).

Contrariando os dados do atual experimento, Shiehzadeh \& Harbers (1974) observaram uma maior retenção de $\mathrm{N}$ no tratamento com amiréia (44 e 70\% de equivalente protéico) comparado à uréia, em ovinos. Teller \& Godeau (1986) não observaram alterações na retenção de $\mathrm{N}$ entre rações com farelo de soja, uréia e amiréia ( $\pm 60 \%$ de equivalente protéico) em vacas lactantes.

A literatura é escassa e os dados não seguem uma mesma lógica (falta consistência), não permitindo uma conclusão sobre o assunto. São necessários mais trabalhos que avaliem o balanço de nitrogênio em bovinos de 
corte, bem como a necessidade de determinações da síntese de proteína microbiana, pois a amiréia apresenta uma fonte de amido com alta taxa de degradação e uma suposta liberação mais lenta de amônia, e sendo assim, é de se esperar uma maior síntese de proteína microbiana, a qual apresenta alto valor biológico, portanto, uma maior retenção de nitrogênio. Isso não foi observado no atual experimento, dando um indicativo que os efeitos da amiréia não estão sendo suficientes para aumentar a retenção de nitrogênio. Uma vez que, amiréia apresentou o $\mathrm{N}$ solúvel muito próximo da uréia convencional (Figura 11 e Quados 3 e 4)

\subsubsection{Degradabilidade in situ}

As frações a, b, taxa de degradação (c), degradabilidade efetiva e potencial para a matéria seca e proteína bruta do farelo de soja e da amiréia estão apresentados no Quadro 3 e a curva de degradação (\%) da matéria seca e proteína bruta estão nas Figuras 10 e 11.

Os resultados obtidos da degradação da matéria seca e proteína bruta do farelo de soja estão de acordo com os observados por Valadares Filho et al. (1990). O NRC (1996) na página 208 faz uma simulação utilizando o nível 2 para estimar a degradabilidade da PB do farelo de soja, obtendo $84 \% \mathrm{com}$ uma taxa de passagem de $2 \% / \mathrm{h} ; 75$ e $68 \%$ para as taxas de 4 e $6 \% / \mathrm{h}$, respectivamente, e $63 \%$ para a taxa de passagem de $8 \% \mathrm{~h}$, valores muito próximos dos observados no atual experimento.

A amiréia apresentou $57,2 \%$ da MS na fração ("a") rapidamente solúvel em água (Quadro 3), ou seja, mais da metade da sua MS é prontamente solúvel em água. Silva (1999), avaliando a degradabilidade in situ da MS da amiréia, observou 58,5\% na fração "a", $27,9 \%$ na fração "b", 13,6\%/h para a taxa degradação, degradabilidade efetiva de 81,$4 ; 76,6$ e 73,4 para as taxas de passagem de 2,4 e $8 \% / h$, respectivamente. Como visto, estes resultados foram similares aos do atual experimento. 


\begin{tabular}{|cccccc|}
\hline \multirow{2}{*}{ Itens $^{1}$} & \multicolumn{2}{c}{ Matéria seca } & & \multicolumn{2}{c|}{ Proteína bruta } \\
\cline { 2 - 3 } \cline { 5 - 6 } \cline { 5 - 6 } & FS & Amiréia & & FS & Amiréia \\
\hline a & 23,0 & 57,2 & & 13,8 & 88,2 \\
b & 75,0 & 35,4 & & 93,3 & 6,8 \\
C, \%/h & 6,4 & 12,1 & & 4,7 & 17,8 \\
Degrad. efetiva & & & & & \\
2\%/h & 83,9 & 87,6 & & 85,6 & 94,9 \\
5\%/h & 73,7 & 82,4 & & 72,6 & 94,8 \\
8\%/h & 68,8 & 78,8 & & 67,4 & 94,7 \\
Degrad. potencial & 98,0 & 92,6 & & 100,0 & 95,0 \\
\hline
\end{tabular}

${ }^{1}$ Itens: a= fração rapidamente solúvel em água; b=fração insolúvel, mas potencialmente degradável; c=taxa de degradação da fração b; degrad.=degradabilidade.

Quadro 3 - Parâmetros da degradabilidade in situ, do farelo de soja (FS) e da amiréia

A fração ("a") rapidamente solúvel em água da PB $(88,2 \%)$ dá um indicativo que o $\mathrm{N}$ na amiréia foi mais solúvel que degradável. $\mathrm{O} N$ potencialmente degradado da amiréia $(95,0 \%)$ foi todo degradado de zero $(88,2 \%)$ a duas horas $(95,0 \%)$, sendo o $N$ totalmente solúvel em um tempo muito curto, como pode ser visualizado na Figura 11. Talvez este tempo seja menor que duas horas, pois não foi avaliado um tempo inferior a este após a hora zero.

A proteína ou equivalente protéico da amiréia (150S) proveniente da uréia é 96,8\%. Considerando a fração solúvel da proteína do milho de $8 \%$ e $100 \%$ a da uréia (NRC, 1996), tem-se $97,0 \%$ do nitrogênio total da amiréia na forma solúvel. Observa-se que apenas 8,8\% (97,0 - 88,2\%) do N solúvel em potencial deixou de estar prontamente solúvel. Mas, se considerar que apenas 
95,0\% do $\mathrm{N}$ da amiréia era potencialmente degradável (Quadro 3), esta estimativa cai para apenas $6,8 \%(95,0-88,2 \%)$.

Estes resultados nos levam a inferir que $\mathrm{o} N$ da amiréia se comporta de uma maneira muito similar ao $\mathrm{N}$ da uréia no rúmen. Como demonstrado por Owens \& Zinn (1988), o pico de amônia ruminal proveniente de NNP é de uma a duas horas após a alimentação. Outra inferência a ser feita é que, em dosagens altas de $\mathrm{N}$ provenientes da amiréia pode ocorrer casos de toxidez por amônia. Confirmando isto, podemos observar na Tabela 16 que a concentração de $\mathrm{N}$ amoniacal no fluido ruminal não diferiu entre uréia e amiréia.

\section{Degradabilidade "in situ" da MS}

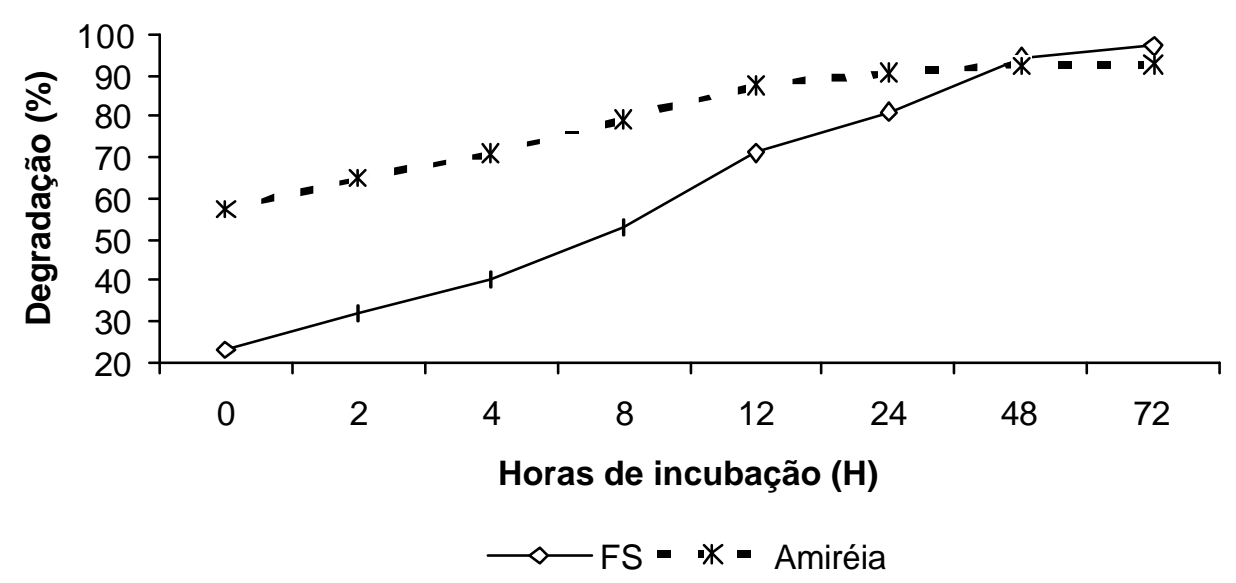

Figura 10. Curvas de degradação da matéria seca (MS) do farelo de soja (FS) e da amiréia (150S), calculadas pelo modelo de Ørskov \& McDonald (1979).

Teixeira et al. (1999) demonstraram que a amiréia 45S não diminuiu a taxa de liberação de nitrogênio (81,5\% na fração "a"), sendo esta similar a uma mistura de milho mais uréia. Feitosa et al. (2000) observaram que 
a amiréia moída apresentou 93\% do nitrogênio total na forma solúvel (fração "a"). Considerando a fração solúvel da proteína do milho de $8 \%$ e $100 \%$ a da uréia (NRC, 1996), tem-se $89 \%$ do nitrogênio total da amiréia na forma solúvel. Este valor está abaixo do observado (93\%), indicando que a amiréia na forma moída não diminuiu a taxa de liberação de nitrogênio.

Estudando a degradabilidade da amiréia moída a $2 \mathrm{~mm}$, Silva (1999) observou que a degradabilidade efetiva $(5,0 \% / \mathrm{h})$ foi apenas sete unidades percentuais superior quando comparada à fração solúvel ("a") da amiréia ( 84,7 e $77,2 \%$, respectivamente), demonstrando que a quase totalidade do nitrogênio da amiréia está na frma solúvel. No entanto, Valadares Filho et al. (1990) observaram uma menor fração solúvel da amiréia moída quando comparada a uma mistura de uréia mais milho moído sem extrusão (61,9 e 88,4, respectivamente). É importante salientar que durante o processo de fabricação da amiréia utiliza-se umidade, pressão e temperatura e se esta última não estiver bem ajustada pode ocorrer reação de Maillard, tornando parte do $\mathrm{N}$ indisponível para o animal (N-FDA) e, conseqüentemente, a redução da fração solúvel.

Uma maneira de reduzir a fração rapidamente solúvel ("a") do $\mathrm{N}$ da amiréa é peletizá-la. Segundo Teixeira et al. (1999), a amiréia (45S) na forma de pellet proporciona uma fração solúvel de aproximadamente $10 \%$ menor quando comparada com a forma moída, produzida com milho ou raspa de mandioca. A amiréia (A-63) com um maior teor de uréia (20\%), quando moída, apresenta aproximadamente $23 \%$ mais nitrogênio solúvel, quando comparada àpeletizada (Feitosa et al., 2000). 
Degradabilidade "in situ" da PB

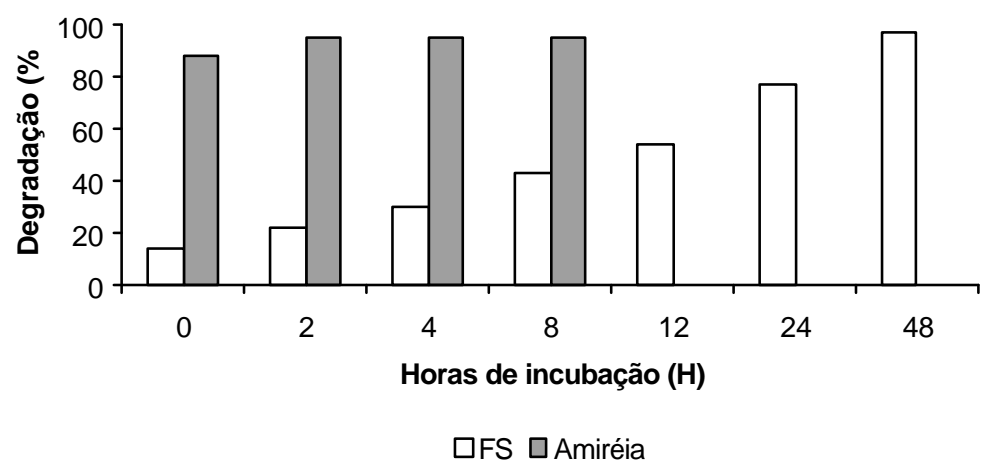

Figura 11 - Degradação da proteína bruta (PB) do farelo de soja (FS) e da amiréia (150S), calculadas pelo modelo de Ørskov \& McDonald (1979).

Carmo et al. (1999), avaliando a degradabilidade da proteína bruta da amiréia contendo $25 \%$ de uréia com diferentes granulometrias (pellet, quebrados ao meio e quebrados em quatro partes iguais), observaram valores de $86,8 \%$ e $58,0 \%$ para a fração solúvel ("a") para a forma quebrada e pellet, respectivamente. Isto sugere que a amiréia quebrada em quatro partes teve o $\mathrm{N}$ totalmente solúvel em um tempo muito curto e a forma inteira liberou o $\mathrm{N}$ mais gradativamente. $\mathrm{O}$ pellet quebrado em dois apresentou comportamento intermediário entre o pellet inteiro e aquele quebrado em quatro partes. Os autores concluíram que a amiréia deve ser fornecida sem qualquer processo de quebra ou moagem, pois consegue-se um melhor efeito da liberação modulada da uréia. No mesmo sentido, Ezequiel et al. (2000), utilizando amiréia com diferentes teores de uréia (20, 25 e 30\%), nas formas moídas e pellet, verificaram que a solubilidade protéica do pellet foi diminuída em 30,3 (93,14 e $62,85)$ unidades percentuais em relação àforma moída.

O processamento físico da amiréia (quebra ou moagem) altera a proporção da fração solúvel da proteína (liberação de nitrogênio), tornando-se 
muito próxima de uma mistura de uréia mais milho sem extrusão. Isto nos leva a pensar que a moagem de $2 \mathrm{~mm}$, utilizada nos alimentos avaliados no procedimento in situ, poderá aumentar a fração solúvel da amiréia e, mesmo o procedimento de lavagem extensiva, manual em água corrente ou em máquinas, poderá destruir o grânulo de amido que envolve a uréia, o que superestimaria a fração solúvel, principalmente a fração nitrogenada.

Alguns dos benefícios sugeridos para amiréia é que ela apresenta uma liberação gradativa de nitrogênio no rúmen. Como visto anteriormente, isto não ocorre se a amiréia estiver na forma moída (Figura 11). Esta alta solubilidade pode levar o animal a uma intoxicação com amônia dependendo da quantidade de amiréia e da dieta, nos dando um forte indicativo de que o nitrogênio da amiréia comporta-se muito similar ao da uréia convencional.

\subsubsection{Simulação da "proteção de cocho" da amiréia}

Os dados da proporção do nitrogênio prontamente solúvel em água da amiréia na forma in natura (sem moagem) estão apresentados no Quadro 4. Os resultados demonstraram que a quase totalidade $(90 \%)$ do nitrogênio da amiréia (150S) está na forma prontamente solúvel, indicando que a amiréia não apresenta uma liberação lenta de nitrogênio, ou seja, não apresenta "proteção de cocho" da uréia contida na amiréia.

Tem sido divulgado nos meios de comunicação e pelas indústrias (Revista DBO Rural, ano 20, № 249, julho de 2001; Revista Alimentação Animal, ano 5, № 20, out/dez de 2000; no site www.amireia.com.br e outros) que a amiréia apresenta uma degradação lenta do nitrogênio, podendo ser utilizada em períodos de chuva (verão). Como visto no Quadro 4, isto não ocorreu, pois os efeitos da amiréia são muito similares aos da uréia convencional, inclusive quanto à possível intoxicação aos animais, tanto por 
consumo de altas quantidades ou por beber água proveniente da chuva acumulada no cocho que contém amiréia pura ou no suplemento.

\begin{tabular}{|cccc|}
\hline \multirow{2}{*}{ Horários $^{1}$} & \multicolumn{2}{c|}{ Repetições } & \multirow{2}{*}{ Médias } \\
\cline { 2 - 3 } & 1 & 2 & \\
\hline T0 & 91,9 & 90,7 & 91,3 \\
T2 & 90,2 & 89,9 & 90,1 \\
\hline
\end{tabular}

${ }^{1} \mathrm{~T} 0=$ tempo que a uréia levou para solubilizar totalmente na água (40 mim); T2=2 horas em contato com a água.

Quadro 4 - Proporção do nitrogênio solúvel da amiréia in natura, em dois horários.

\subsection{Conclusões}

Quando as exigências em PDR são atendidas (via uréia ou amiréia 150S), em dietas com alta proporção de concentrado, melhora o consumo dos nutrientes e a digestibilidade da fibra em bovinos de corte, quando comparado a uma fonte de proteína verdadeira (farelo de soja) sem atender as exigências em PDR.

A suplementação com uréia (dieta adequada em PDR) promoveu uma maior retenção de nitrogênio ( $\mathrm{g} / \mathrm{d}$ e \% do $\mathrm{N}$ consumido) e valor biológico da proteína ( $\mathrm{N}$ retido, \% do digerido) em bovinos de corte, em relação ao uso de uma fonte de proteína verdadeira (farelo de soja) sem atender as exigências em PDR ou atendê-las via amiréia.

A uréia promove uma maior concentração de amônia ruminal do que o farelo de soja.

A amiréia promove resultados similares a uréia convencional no consumo dos nutrientes, digestibilidade, parâmetros ruminais e sanguíneos de bovinos de corte confinados. 
As fontes nitrogenadas (farelo de soja, uréia e amiréia) não alteram a concentração de nitrogênio uréico e de glicose no plasma.

O nitrogênio proveniente da amiréia é praticamente todo prontamente solúvel em água (fração "a") e também a amiréia não promove "proteção de cocho" do nitrogênio. Esse $\mathrm{N}$ solúvel, com base na literatura, poderá provocar intoxicações aos animais, tanto por consumo de altas quantidades ou por beber água proveniente da chuva acumulada no cocho que contém amiréia pura ou no suplemento.

O bagaço de cana-de-açúcar in natura promove boa estabilidade ruminal quando utilizado como única fonte de volumoso (20\% da MS) em dietas com alto teor de concentrado ( $80 \%$ da MS). 


\section{SUBSTITUIÇÃO TOTAL DO FARELO DE SOJA POR URÉIA OU AMIRÉIA, EM DIETAS COM ALTO TEOR DE CONCENTRADO, SOBRE O DESEMPENHO DE BOVINOS DE CORTE CONFINADOS}

\section{Resumo}

Oitenta e um machos não castrados das raças Nelore (27), Canchim (27) e Holandesa (27), com peso médio inicial de $250 \mathrm{~kg}$ e idade média de 15 meses, foram utilizados para avaliar a substituição total de uma fonte de proteína verdadeira (farelo de soja), em uma dieta deficiente em PDR, por uréia ou amiréia (fonte de nitrogênio não protéico de suposta liberação gradativa de nitrogênio), ambas em uma dieta adequada em PDR, sobre o desempenho de bovinos confinados. O delineamento experimental foi 0 de blocos ao acaso com três tratamentos, tendo três animais por baia e nove baias por tratamento. Os blocos foram arranjados segundo o peso inicial e raça. Os tratamentos foram: 1) farelo de soja (FS); 2) uréia e 3) amiréia (A-150S) em

dietas isoprotéicas $(13,0 \%)$ utilizando o bagaço in natura (BIN) como única fonte de volumoso (20\% da MS). O consumo de MS foi 6,56; 7,18 e 6,97 kg/dia, 0 ganho de peso vivo foi 0,$889 ; 1,114$ e $1,088 \mathrm{~kg} /$ dia e a conversão alimentar foi 7,$3 ; 6,5$ e $6,7 \mathrm{~kg} \mathrm{MS} / \mathrm{kg}$ de ganho para os tratamentos farelo de soja, uréia e amiréia, respectivamente. O tratamento FS apresentou menor consumo e ganho de peso $(P<0,01)$ e pior $(P<0,01)$ conversão alimentar. Os tratamentos uréia e $A-150 S$ não diferiram $(P>0,05)$ entre si. 


\section{TOTAL REPLACEMENT OF SOYBEAN MEAL BY UREA OR STAREA IN HIGH GRAIN DIETS FOR BEEF CATTLE}

\section{Summary}

Eighty-one yearling intact (27 Nellore, 27 Canchim and 27 Holstein) males, with initial body weight of $250 \mathrm{~kg}$, were used to evaluate the effects of nitrogen sources on feedlot performance. Animals were assigned to a completely random block design according to initial weight and breed. There were 9 pen/treatment with 3 anima/pen. Experimental treatments were: 1) soybean meal, 2) urea and 3) starea. Diets contained 13\% CP and were composed of $80 \%$ concentrate and $20 \%$ in natura sugarcane bagasse. DMI was $6.56 ; 7.18$ and $6.97 \mathrm{~kg} /$ day, average daily gain was $0.889 ; 1.114$ and 1.088 $\mathrm{kg} /$ day and feed convertion was $7.3 ; 6.5$ and $6.7 \mathrm{~kg} D M / \mathrm{kg}$ gain for soybean meal, urea and starea, respectively. Soybean meal reduced $(\mathrm{P}<0.01) \mathrm{DMI}$, average daily gain and feed efficiency and there was no difference $P>0.05$ ) between urea and starea treatments.

\subsection{Introdução}

Os microrganismos ruminais são capazes de sintetizar proteína microbiana a partir de amônia e esqueleto carbônico, podendo o nitrogênio não protéico ser uma das fontes de amônia. Neste contexto, enquadra-se a amiréia e a uréia, ambas fontes de nitrogênio não protéico.

Fontes de nitrogênio não protéico têm a vantagem de serem mais

econômicas que fontes de proteína verdadeira na mesma quantidade de 
nitrogênio. Entretanto, a fonte de nitrogênio não protéico mais utilizada (uréia) apresenta uma rápida liberação de amônia no rúmen que, dependendo da quantidade utilizada, pode exceder a capacidade de utilização pelos microrganismos. Conseqüentemente, este excesso é absorvido pela parede ruminal. Essa amônia na corrente sanguínea, dependendo da quantidade, pode ser tóxica para o animal, devido a incapacidade do fígado em metabolizá-la. Porém, do que é metabolizado, a maior parte é transformada em uréia, envolvendo gasto de energia. Essa uréia circulante poderá reciclar para o rúmen, via parede ruminal ou saliva, ou ser excretada via urina.

Uma fonte de nitrogênio não protéico com uma liberação lenta de amônia teria vantagens de aumentar a disponibilidade da mesma para síntese microbiana e reduzir problemas com toxidez (Bartley \& Deyoe, 1975).

O processo de extrusão consiste na união da uréia com a molécula de amido gelatinizado, através da exposição à pressão, temperatura e umidade, por um determinado tempo, obtendo-se assim a amiréia. $O$ benefício dessa prática é um aumento na velocidade de fermentação do amido no rúmen aliado à redução da intensidade de liberação de amônia oriunda da uréia, compatibilizando os dois fatores para a síntese de proteína microbiana (Silva et al., 1994 e Seixas et al., 1999).

Em épocas de preços vantajosos de concentrados, dietas com alto teor de concentrado têm se tornado viáveis economicamente, já que o ganho de peso é mais rápido, havendo redução nos custos de mão-de-obra, tornando a atividade mais rentável (Bulle, 2000). Neste contexto, o bagaço de cana-de-açúcar in natura vem demonstrando ser uma fonte de fibra interessante (Henrique et al., 1999 e Bulle et al. 2002a)

O objetivo do presente trabalho foi comparar a substituição total de uma fonte de proteína verdadeira (farelo de soja), em uma dieta deficiente em PDR, por uréia ou amiréia (fonte de nitrogênio não protéico de suposta liberação gradativa de nitrogênio), sendo as duas fontes utilizadas em uma 
dieta adequada em PDR, utilizando-se o BIN como única fonte de volumoso (20\% da MS), sobre o desempenho de bovinos de corte em crescimento.

\subsection{Material e métodos}

\subsubsection{Animais e instalações experimentais}

Foram utilizados 81 machos não castrados (27 Nelore, 27 Canchim e 27 Holandês), com peso médio inicial de $250 \mathrm{~kg}$ e média de 15 meses de idade.

O experimento foi conduzido nas instalações no Centro de Produção Intensiva de Bovinos de Corte do Departamento de Zootecnia ESALQ-USP, onde os animais foram alojados em baias $(3 \times 11 \mathrm{~m})$ cobertas, com piso, cocho e bebedouro de concretos, sendo distribuídos três animais por baia, em um total de 27 baias. O período experimental foi realizado durante 0 período de agosto a dezembro de 2000.

Os animais foram previamente everminados e receberam uma dose de complexo vitamínico $\mathrm{ADE}$ na fase de adaptação às dietas e à instalações experimentais.

\subsubsection{Tratamentos}

Os animais foram alimentados com dietas contendo bagaço de cana-de-açúcar in natura (BIN) como volumoso (20\%) e $80 \%$ de concentrado (Tabela 20), sendo que os tratamentos experimentais foram feitos pela substituição total da fonte de proteína verdadeira (farelo de soja - FS), em uma dieta deficiente em PDR, por uréia ou amiréia (A-150S - fonte de nitrogênio não 
protéico de suposta liberação gradativa de nitrogênio), sendo as duas fontes utilizadas em uma dieta adequada em PDR.

As fontes de uréia utilizadas foram: a uréia (adubo convencional) e a uréia convencional extrusada, utilizando-se o milho como a fonte de amido (Amiréia $150 S^{\circledR}$, Pajoara indústria e comércio, Campo Grande, MS).

Os tratamentos (Tabela 20) foram formulados para resultarem em dietas isoprotéicas e isoenergéticas, utilizando o programa do NRC (1996) de bovinos de corte. A composição da dieta em ingredientes e nutrientes estão apresentados nas Tabela 20 e 21.

Os concentrados foram misturados previamente em um misturador horizontal (marca Lucato, capacidade de $250 \mathrm{~kg}$ ). Na hora do fornecimento da alimentação, o BIN e o concentrado, nas suas respectivas proporções, foram misturados utilizando um vagão para ração completa (marca Siltomac, com capacidade de $1800 \mathrm{~kg}$ ) e fornecidos como ração completa diariamente (18h). 
Tabela 20. Composição em ingredientes e composição química das dietas (\% da MS).

\begin{tabular}{|c|c|c|c|}
\hline \multirow{2}{*}{ Ingredientes } & \multicolumn{3}{|c|}{ Tratamentos } \\
\hline & FS & Uréia & A-150S \\
\hline Bagaço in natura (BIN) & 20,5 & 20,5 & 20,5 \\
\hline Milho moído & 27,5 & 33,2 & 30,9 \\
\hline Polpa cítrica & 33,1 & 41,0 & 41,0 \\
\hline Farelo de soja (FS) & 16,5 & - & - \\
\hline Uréia & - & 2,46 & - \\
\hline Amiréia 150S (A-150S) & - & - & 4,78 \\
\hline Mistura mineral ${ }^{1}$ & 1,37 & 1,37 & 1,37 \\
\hline Cloreto de potássio & - & 0,41 & 0,41 \\
\hline Bicarbonato de sódio & 1,09 & 1,09 & 1,09 \\
\hline \multicolumn{4}{|l|}{ Composição química } \\
\hline MS (\% da matéria natural) & 79,2 & 79,3 & 79,3 \\
\hline Proteína bruta & 12,8 & 13,1 & 13,1 \\
\hline Fibra em detergente neutro & 34,3 & 36,1 & 33,9 \\
\hline Fibra em detergente ácido & 25,4 & 27,5 & 26,4 \\
\hline Matéria mineral & 5,5 & 5,5 & 5,7 \\
\hline Extrato etéreo & 2,3 & 2,5 & 2,4 \\
\hline
\end{tabular}


Tabela 21. Composição das frações nitrogenadas das dietas (\% da MS).

\begin{tabular}{lccc}
\hline \multirow{2}{*}{ Itens $^{2}$} & \multicolumn{3}{c}{ Tratamentos $^{1}$} \\
\cline { 2 - 4 } & FS & Uréia & A-150S \\
\hline PB, \% & 12,8 & 13,1 & 13,1 \\
PBsol, \% da PB & 13,4 & 59,3 & 61,4 \\
PBIDN, \% da PB & 19,1 & 16,8 & 20,2 \\
PBIDA, \% da PB & 12,6 & 11,8 & 11,7 \\
PDR $^{3}, \%$ da PB & 58,4 & 75,3 & 75,3 \\
PDR, \% da MS & 7,5 & 9,9 & 9,9 \\
\hline
\end{tabular}

${ }^{1} \mathrm{FS}$ =farelo de soja; $\mathrm{A}-150 \mathrm{~S}=$ amiréia;

${ }^{2} \mathrm{~PB}=$ proteína bruta. PBsol= proteína bruta solúvel; PBIDN= proteína bruta insolúvel em detergente neutro; PBIDA= proteína bruta insolúvel em detergente ácido; PDR= proteína bruta degradável no rúmen;

${ }^{3}$ Estimada pelo modelo do NRC (1996) nível 1, para BIN usou 25\% (Fox et al., 2000).

\subsubsection{Período experimental}

O período experimental teve duração de 118 dias, sendo os primeiros 20 dias destinados ao processo de adaptação dos animais às instalações e à dietas experimentais, e o restante do período foi segmentado em quatro sub-períodos, sendo três de 28 dias e um de 14 dias.

\subsubsection{Colheita de dados referentes ao consumo de matéria seca}

Os dados de consumo de MS por animal/dia foram obtidos através da diferença entre a quantidade de MS fornecida e a MS da sobra. A quantidade de MS fornecida foi determinada diariamente com a utilização de balança eletrônica do vagão para ração completa. A quantidade de alimento oferecido foi ajustado diariamente com base nas sobras do dia anterior, 
objetivando um mínimo possível de sobra, sendo esta registrada semanalmente.

Durante o período experimental, foram amostrados as sobras e os alimentos oferecidos uma vez por semana, os quais foram compostos por sub-período e tratamento.

As amostras foram conservadas congeladas a $-10^{\circ} \mathrm{C}$ até serem descongeladas e secas em estufas com ventilação forçada $\left(55^{\circ} \mathrm{C}\right)$ por 72 horas e, posteriormente, por 12 horas a $105^{\circ} \mathrm{C}$ para determinação de matéria seca de acordo com Silva (1990).

\subsubsection{Análise bromatológica das dietas e sobras}

Amostras do alimento oferecido e das sobras foram secas em estufas com ventilação forçada à temperatura de $55^{\circ} \mathrm{C}$ por 72 horas e moídas em moinhos tipo Wiley (Marconi, Piracicaba, SP) primeiramente em peneira com crivos de $2 \mathrm{~mm}$ e após em peneiras com crivos de $1 \mathrm{~mm} \mathrm{e}$, posteriormente, por 12 horas a $105^{\circ} \mathrm{C}$ para determinação de matéria seca de acordo com Silva, (1990); MM, EE e PB de acordo com AOAC (1990); FDN e FDA, de acordo com o método de Van Soest et al. (1991), não seqüencial, utilizando amilase e sulfito de sódio nas determinações de FDN. A MO foi obtida pela subtração da MM da MS.

\subsubsection{Pesagem dos animais}

Os animais foram pesados no final do período de adaptação e no final de cada sub-período experimental. As pesagens dos animais foram feitas com jejum de 16 horas de alimento. 


\subsubsection{Delineamento experimental e análise estatística}

O delineamento experimental utilizado foi 0 de blocos casualizados, sendo os blocos arranjados de acordo com peso inicial e raça, tendo três animais por baia e nove baias por tratamento. Os dados foram analisados pelo procedimento MIXED do programa estatístico SAS (1988). Foi utilizado o seguinte modelo estatístico:

$$
Y_{i j k}=M+B_{i}+F P_{j}+P_{k}+F P_{j} x P k+E_{i j k}
$$

Onde:

$M=$ Média geral

$\mathrm{B}_{\mathrm{i}}=$ Efeito do bloco

$\mathrm{FP}_{\mathrm{j}}=$ Efeito da fonte protéica

$\mathrm{P}_{\mathrm{k}}=$ Efeito de período

$\mathrm{FP}_{\mathrm{j}} \mathrm{xP} \mathrm{P}_{\mathrm{k}}=$ Interações entre a fonte protéica e o período

$E_{\mathrm{ijk}}=$ Efeito aleatório

Este modelo foi utilizado para analisar todas as variáveis, exceto o consumo de matéria seca, onde utilizou-se semana no lugar de período. O efeito bloco foi considerado efeito aleatório.

As diferenças entre os tratamentos para as diversas variáveis analisadas foram verificadas através do teste Tukey utilizando o comando LSMEANS/PDIFF, considerando $5 \%(\mathrm{P}<0,05)$ como nível de significância e até $10 \%$ como tendência $(P<0,10)$. 


\subsection{Resultados e discussão}

Os dados de consumo de MS, ganho de peso diário e conversão alimentar estão apresentados na Tabela 22. Observando a Tabela 22, não se verifica diferenças entre os tratamentos contendo uréia e amiréia. $O$ tratamento com farelo de soja apresentou um menor $(P<0,05)$ consumo de MS, ganho de peso e também pior $(\mathrm{P}<0,05)$ conversão alimentar (Tabela 22), em relação aos demais tratamentos (uréia e amiréia).

O menor consumo de matéria seca no tratamento com farelo de soja deve ter ocorrido devido a menor fração de proteína degradável no rúmen (Tabela 21). Alterações no consumo ocorrem quando a quantidade de proteína dietética não é suficiente para produzir quantidade adequada de amônia ruminal, sendo importante conhecer as frações protéicas da proteína da dieta (Ørskov, 1988). Segundo os modelos NRC (1996) e CNCPS (Fox et al., 2000) o balanço de nitrogênio no rúmen ficou negativo no tratamento com farelo de soja e positivo nos demais. Ferrell et al. (2001) concluíram que suplementação com PNDR promove benefícios para o animal, mas só deve ocorrer após satisfazer as exigências em PDR, estando de acordo com os dados do atual experimento.

As bactérias fermentadoras de carboidratos fibrosos utilizam amônia como única fonte de nitrogênio, sendo estas altamente prejudicadas quando ocorre uma deficiência de nitrogênio degradável no rúmen, levando a um menor desaparecimento dos carboidratos fibrosos, diminuindo assim a taxa de passagem e conseqüentemente, o consumo de matéria seca (Russel et al., 1992 e Tedeschi et al., 2000). Isso foi confirmado com a redução na digestibilidade da fibra (FDN e FDA; Tabela 6) no tratamento com farelo de soja (deficiente em PDR), no experimento metabólico. O menor consumo de MS proporcionou um menor aporte energético para o animal e, consequentemente, um menor ganho de peso diário. 
As dietas do atual experimento com NNP (uréia ou amiréia) apresentaram 70\% da PDR proveniente do NNP (Tabelas 20 e 21), proporcionando um maior consumo e desempenho (Tabela 22). Animais pastejando forragem de baixa qualidade ( $\mathrm{PB}=2,4 \%$ e $\mathrm{FDN}=73,0 \%$ ) diminuíram o consumo quando a uréia ( $3,2 \%$ do suplemento) contribuiu com mais de $40 \%$ da PDR. Animais confinados recebendo feno de sorgo ( $\mathrm{PB}=4,4 \%$ e $\mathrm{FDN}=58,9 \%$ ) como volumoso e uma dieta com até $60 \%$ da PDR proveniente da uréia $(4,8 \%$ do concentrado) não alteraram o consumo (Köster et al., 2002). O limite de inclusão de uréia na dieta parece estar relacionado com a dieta (qualidade da forragem, tipo de carboidrato, etc) e o manejo (pastejo, confinamento, etc).

Tabela 22. Desempenho de bovinos de corte confinados e suplementados com fontes nitrogenadas.

\begin{tabular}{|c|c|c|c|c|c|}
\hline \multirow[b]{2}{*}{ Itens $^{2}$} & \multicolumn{3}{|c|}{ Tratamentos $^{1}$} & \multirow[b]{2}{*}{$\mathrm{EPM}^{3}$} & \multirow[b]{2}{*}{$\mathrm{P}^{4}$} \\
\hline & FS & Uréia & $A-150 S$ & & \\
\hline Peso inicial, kg & 279,8 & 265,4 & 269,4 & 5,47 & 0,3416 \\
\hline Peso final, $\mathrm{kg}$ & $367,3^{b}$ & $374,6^{a}$ & $374,2^{a}$ & 5,89 & 0,0001 \\
\hline CMS, kg/d & $6,56^{b}$ & $7,18^{\mathrm{a}}$ & $6,97^{a}$ & 0,42 & 0,0001 \\
\hline$\% P V$ & $1,98^{b}$ & $2,19^{a}$ & $2,14^{\mathrm{a}}$ & 0,11 & 0,0069 \\
\hline $\mathrm{g} / \mathrm{kgPV}^{0,75}$ & $85,2^{b}$ & $92,7^{a}$ & $90,6^{a}$ & 4,79 & 0,0116 \\
\hline GPV, kg/d & $0,889^{b}$ & $1,114^{\mathrm{a}}$ & $1,088^{a}$ & 0,05 & 0,0001 \\
\hline CA, kg MS/kg ganho & $7,3^{\mathrm{a}}$ & $6,5^{b}$ & $6,7^{b}$ & 0,39 & 0,0014 \\
\hline
\end{tabular}

Alguns autores (Thompson et al., 1972; Schmidt et al., 1973; Seixas et al., 1999 e Teixeira et al., 2000), utilizando novilhos em crescimento, 
observaram resultados similares aos do atual experimento, no tocante ao consumo de matéria seca, quando compararam amiréia e uréia. Por outro lado, não verificaram alterações no consumo de matéria seca quando avaliaram fontes de nitrogênio não protéico (uréia e amiréia) e farelo de soja (Thompson et al., 1972; Schmidt et al., 1973 e Teixeira et al., 2000) ou farelo de algodão (Seixas et al., 1999). Da mesma foram, Silva et al. (1994) e Salman et al. (1997) também não observaram alterações no consumo de matéria seca entre farelo de soja, uréia e amiréia (Silva et al., 1994) e farelo de algodão, uréia e amiréia (Salman et al., 1997 e Ezequiel et al., 2001a) em borregos. No atual experimento, houve uma redução no consumo de matéria seca no tratamento com farelo de soja.

Stiles et al. (1970) sugeriram que a extrusão provoca a incorporação da uréia na estrutura do amido, promovendo uma melhor aceitabilidade do concentrado. Neste sentido, Salman et al. (1997) sugeriram que amiréia pode aumentar a aceitação da uréia das rações por parte dos animais, não ocorrendo isto no atual experimento, onde o consumo de matéria seca do tratamento com uréia e amiréia foram similares.

Revendo dez anos de pesquisa com amiréia, Bartley \& Deyoe (1975) sumarizaram diversos trabalhos totalizando 12 comparações de ganho de peso diário e conversão alimentar em novilhos em terminação, recebendo uréia ou amiréia. Estes autores observaram que em nenhuma das avaliações ocorreram diferenças, sendo que as médias de todas as comparações foram iguais $\left(1,25 \mathrm{~kg}\right.$ animal $\left.{ }^{-1} \cdot \mathrm{d}^{-1}\right)$, para uréia e amiréia, estando de acordo com os dados do atual experimento.

O desempenho dos animais alimentados com amiréia ou uréia não diferiu, talvez porque a amiréia liberou muito rapidamente o nitrogênio, não exercendo uma "proteção" do nitrogênio prontamente solúvel, ou o sistema de reciclagem de nitrogênio no rúmen se adapta facilmente a rapidez da liberação de amônia pelas fontes de nitrogênio não protéico, desde que as concentrações 
não atinjam níveis tóxicos (Owens \& Zinn 1988). No entanto, está de acordo com a maioria dos dados da literatura.

Alguns autores (Carmo et al., 1999; Teixeira et al., 1999; Ezequiel et al., 2000 e Feitosa et al., 2000), avaliando a degradabilidade da proteína bruta da amiréia com diferentes granulometrias, observaram que 0 processamento físico da amiréia (quebra ou moagem) altera a fração solúvel da proteína (liberação de nitrogênio), tornando a fração solúvel da proteína da amiréia moída muito próxima de uma mistura de uréia mais milho sem extrusão. No atual experimento, utilizou-se uma amiréia com alto equivalente protéico (150) e na forma não peletizada.

Observando os Quadros 5 e 6 pode-se inferir que a amiréia utilizada não apresentou "proteção" do nitrogênio, fato este, confirmado no desempenho dos animais (Tabela 22), onde verifica-se resultados similares entre uréia e amiréia.

O benefício sugerido para amiréia é que ela apresenta uma liberação gradativa de nitrogênio no rúmen e, como visto anteriormente, isto não ocorre ou ocorre muito pouco se a amiréia estiver na forma moída ou de pellet quebrado e esta alta solubilidade pode levar o animal a uma intoxicação com amônia, dependendo da quantidade de amiréia na dieta. A amiréia na forma de pellet diminui um pouco a solubilidade do nitrogênio, mas esta ainda é bem elevada quando comparada æ̀ fontes de proteína verdadeira. No entanto, a amiréia na forma de pellet pode apresentar segregação nas misturas, dificultando a sua utilização.

\subsubsection{Avaliação dos modelos NRC (1996) e CNCPS (Fox et al., 2000) em raças de bovinos de corte}

Os dados obtidos da avaliação dos modelos estão apresentados nas Tabelas 23, 24 e 25. Os tratamentos de nitrogênio não protéico (uréia e 
amiréia) foram agrupados, pois apresentaram resultados muitos similares, como discutido anteriormente. Os animais foram divididos por raça dentro de tratamentos. Utilizou-se o NRC (1996) nível 1 e "Cornell Net Carbohydrate and Protein System" (CNCPS) nível 2 (Fox et al., 2000) para a realização das simulações. Primeiramente, foi feita uma simulação normal sem correção para consumo de MS e depois, foi realizada outra, onde se utilizou o consumo observado de MS.

Tabela 23. Avaliação de modelos para predizer o consumo de MS e o desempenho de bovinos da raça Nelore confinados.

\begin{tabular}{|c|c|c|c|c|c|}
\hline Itens $^{5}$ & Tratamento $^{6}$ & $\begin{array}{l}\mathrm{CMS}^{1} \\
\mathrm{~kg} / \mathrm{d}\end{array}$ & $\begin{array}{l}\mathrm{EDG}^{2} \\
\mathrm{~kg} / \mathrm{d}\end{array}$ & $\begin{array}{c}\mathrm{PMDG}^{3} \\
\mathrm{~kg} / \mathrm{d}\end{array}$ & $\begin{array}{c}\text { GPVobs. }^{4}{ }^{\mathrm{kg} / \mathrm{d}} \\
\end{array}$ \\
\hline & & \multicolumn{3}{|c|}{$\mathrm{CNCPS}^{7}$} & \\
\hline Estimativa & FS & 7,53 & 1,30 & 1,65 & 0,68 \\
\hline Estimativa com COMS & FS & 5,07 & 0,68 & 0,96 & 0,68 \\
\hline Estimativa & NNP & 7,38 & 1,24 & 1,45 & 0,95 \\
\hline \multirow[t]{2}{*}{ Estimativa com COMS } & NNP & 5,70 & 0,84 & 1,04 & 0,95 \\
\hline & & \multicolumn{3}{|c|}{$\operatorname{NRC}(1996)^{8}$} & \\
\hline Estimativa & FS & 7,40 & 1,39 & 1,67 & 0,68 \\
\hline Estimativa com COMS & FS & 5,07 & 0,71 & 0,82 & 0,68 \\
\hline Estimativa & NNP & 7,48 & 1,35 & 1,19 & 0,95 \\
\hline Estimativa com COMS & NNP & 5,70 & 0,86 & 0,69 & 0,95 \\
\hline
\end{tabular}

$\mathrm{Na}$ Tabela 23, foi verificado que ambos os modelos superestimaram o consumo de MS dos animais Nelore (Bos indicus) em 32\% no tratamento com farelo de soja (deficiente em PDR) e $23 \%$ no tratamento com 
NNP, indicando que a estimativa de consumo de MS para animais da raça Nelore pode apresentar erros consideráveis, superestimando o desempenho animal (Tabela 23). Assim, o desempenho pode ser superestimado em até $49 \%$ no tratamento deficiente em PDR e mais de $20 \%$ no tratamento com NNP, independentemente do modelo. Outro fator a considerar, é que uma superestimativa do consumo resulta em deficiências nutricionais, uma vez que, a densidade de nutrientes é menor que o necessário, diminuindo o desempenho.

Os dois modelos apresentaram dados de desempenho bem próximos dos observados quando foi feita a correção para o consumo observado de MS, no tratamento com deficiência em PDR (farelo de soja), sendo o GPV observado muito próximo do ganho limitante por energia (EDG). No entanto, no tratamento com PDR adequada (via NNP), o CNCPS subestimou o ganho em cerca de 12\% comparado ao ganho limitante (EDG), ficando o ganho atual entre a estimativa do ganho por energia (EDG) e proteína (PMDG). Provavelmente, o modelo não está bem ajustado para dietas com alto NNP, que estimula uma maior síntese de proteína microbiana e aumenta a energia provinda da fermentação de carboidratos (Russell et al., 1992).

Corrigindo o consumo de MS, o modelo do NRC (1996) subestimou o ganho (10\%) em função da energia (EDG) no tratamento com PDR adequada, mas o modelo nesta situação estima que o ganho limitante é função da proteína metabolizável (PMDG), sendo o ganho subestimado em $38 \%$, quando relacionado ao GPV observado, demonstrando que o NRC (1996) nesta situação (PDR ajustada via NNP) subestimou muito a proteína metabolizável, provavelmente a do componente microbiano. Uma vez que, no tratamento deficiente em PDR (farelo de soja), provavelmente, ocorreu uma menor síntese de proteína microbiana (menor CMS; Tabela 22) e nesta situação a predição foi melhor.

No NRC (1996), foi considerado que animais Bos indicus apresentam uma exigência de energia de manutenção 10\% inferior aos Bos 
taurus. Entretanto, Tedeschi et al. (2002) não observaram diferenças na exigência energia de manutenção de animais Nelore (Bos indicus) em relação a Bos taurus, quando alimentaram os animais com dietas contendo alta proporção de forragens (comum no Brasil). No mesmo sentido, Krehbeil et al. (2000) não observaram alterações no desempenho e metabolismo entre animais Bos indicus cruzados (Brahman x MARC III) e animais MARC III alimentados com dietas com alto teor de grãos (95\%).

Tabela 24. Avaliação de modelos para predizer o consumo de MS e o desempenho de bovinos da raça Canchim confinados.

\begin{tabular}{|c|c|c|c|c|c|}
\hline Itens $^{5}$ & Tratamento $^{6}$ & $\begin{array}{l}\mathrm{CMS}^{1} \\
\mathrm{~kg} / \mathrm{d}\end{array}$ & $\begin{array}{c}\mathrm{EDG}^{2} \\
\mathrm{~kg} / \mathrm{d}\end{array}$ & $\begin{array}{c}\mathrm{PMDG}^{3} \\
\mathrm{~kg} / \mathrm{d}\end{array}$ & $\begin{array}{c}\text { GPVobs. }^{4} \\
\mathrm{~kg} / \mathrm{d}\end{array}$ \\
\hline & & \multicolumn{3}{|c|}{$\mathrm{CNCPS}^{7}$} & \\
\hline Estimativa & FS & 7,95 & 1,29 & 1,74 & 1,00 \\
\hline Estimativa com COMS & FS & 6,60 & 0,98 & 1,36 & 1,00 \\
\hline Estimativa & NNP & 8,04 & 1,19 & 1,57 & 1,24 \\
\hline \multirow[t]{2}{*}{ Estimativa com COMS } & NNP & 7,10 & 0,99 & 1,36 & 1,24 \\
\hline & & \multicolumn{3}{|c|}{$\mathrm{NRC}(1996)^{8}$} & \\
\hline Estimativa & FS & 7,80 & 1,38 & 1,77 & 1,00 \\
\hline Estimativa com COMS & FS & 6,60 & 1,05 & 1,32 & 1,00 \\
\hline Estimativa & NNP & 7,90 & 1,35 & 1,25 & 1,24 \\
\hline Estimativa com COMS & NNP & 7,10 & 1,12 & 1,01 & 1,24 \\
\hline
\end{tabular}

Com base nestes dados, pode-se inferir que o NRC (1996) e CNCPS (Fox et al., 2000) precisam ser ajustados para estimativas de consumo de MS de animais em crescimento da raça Nelore (Bos indicus). Estes modelos 
apresentaram boas estimativas de desempenho quando o consumo de MS observado no tratamento com farelo de soja (deficiente em PDR) foi utilizando. No tratamento com NNP (adequado em PDR), ambos subestimaram o ganho com o COMS (10\% no CNCPS e $38 \%$ no NRC, 1996), necessitando de ajuste o modelo do NRC (1996) para esta situação.

Tabela 25. Avaliação de modelos para predizer o consumo de MS e o desempenho de bovinos da raça Holandesa confinados.

\begin{tabular}{|c|c|c|c|c|c|}
\hline Itens $^{5}$ & Tratamento $^{6}$ & $\begin{array}{l}\mathrm{CMS}^{1} \\
\mathrm{~kg} / \mathrm{d}\end{array}$ & $\begin{array}{r}E D G^{2} \\
\mathrm{~kg} / \mathrm{d}\end{array}$ & $\begin{array}{c}\mathrm{PMDG}^{3} \\
\mathrm{~kg} / \mathrm{d}\end{array}$ & $\begin{array}{c}\text { GPVobs. }^{4} \\
\mathrm{~kg} / \mathrm{d}\end{array}$ \\
\hline & & \multicolumn{3}{|c|}{ CNCPS $^{7}$} & \\
\hline Estimativa & FS & 7,95 & 1,29 & 1,74 & 0,99 \\
\hline Estimativa com COMS & FS & 8,30 & 1,37 & 1,85 & 0,99 \\
\hline Estimativa & NNP & 8,05 & 1,22 & 1,59 & 1,13 \\
\hline \multirow[t]{2}{*}{ Estimativa com COMS } & NNP & 8,30 & 1,27 & 1,64 & 1,13 \\
\hline & & \multicolumn{3}{|c|}{ NRC $(1996)^{8}$} & \\
\hline Estimativa & FS & 8,40 & 1,44 & 1,99 & 0,99 \\
\hline Estimativa com COMS & FS & 8,30 & 1,41 & 1,95 & 0,99 \\
\hline Estimativa & NNP & 8,54 & 1,41 & 1,45 & 1,13 \\
\hline Estimativa com COMS & NNP & 8,30 & 1,34 & 1,37 & 1,13 \\
\hline
\end{tabular}

Pode-se observar que os dados obtidos da avaliação dos modelos em animas Canchim (Tabela 24) são similares aos dados dos animais da raça Nelore (Tabela 23), sendo apenas a estimativa de consumo de MS melhorada em relação à observada, principalmente em dietas com PDR ajustada (via NNP). Provavelmente, isto é devido à presença de sangue de 
animal europeu (Charolês) nesta raça (foi considerado Canchin sendo 1/2 sangue Nelore e $1 / 2$ Charolês, uma vez que, nos modelos não apresentam esta raça no default). As raças européias (Bos taurus) estão sendo melhoradas há mais tempo que as indianas (Bos indicus) e também são mais estudadas, tendo mais dados para avaliar os modelos, como é observado na Tabela 25, cujos modelos predizem muito bem o consumo de MS da raça Holandesa (Bos taurus), independentemente do tratamento.

As predições de desempenho utilizando o consumo observado, superestimaram o GPV dos animais Holandês, principalmente no tratamento deficiente em PDR (farelo de soja), ao contrário das outras raças. Esta superestimativa de desempenho desta raça (Tabela 25) pode ser devido ao modelo ou devido ao fato de alguns animais terem apresentado problema de casco. No entanto, como o consumo não foi prejudicado segundo o modelo, o mais provável desta superestimativa do desempenho seja o modelo. Nas dietas com PDR adequada, a estimativa do desempenho é razoável, sendo superestimada entre 11 a $15 \%$.

Resultado similar foi observado por Block et al. (2001) no tocante ao consumo de MS, quando avaliaram o modelo do NRC (1996), utilizando novilhos (Angus, Charolês e Hereford) em terminação. No entanto, o desempenho predito pelo modelo foi subestimado em relação ao observado, discordando dos resultados da atual avaliação (Tabela 25).

O tratamento com farelo de soja (deficiente em PDR), mesmo com $7,4 \%$ de PDR (\% da MS), não foi suficiente para maximizar o consumo, 0 ganho e a eficiência alimentar. O tratamento com NNP (PDR adequada) continha $9,9 \%$ de PDR ( $\%$ da MS; Tabela 21), o que pode ter sido responsável por um maior consumo de MS, ganho e uma melhor conversão alimentar (Tabela 22), demonstrando que o NRC (1996) é adequado para estimar a exigência de PDR neste tipo de dieta. Alguns autores (Milton et al., 1997b; Shain et al., 1998 e Cooper et al., 2002) observaram que a exigência de 6,8\% (\% da MS) de PDR estimada pelo NRC (1996) nível 1 está correta para animais 
em terminação com dietas àbase de milho laminado. No entanto, Cooper et al. (2002) observaram que a estimativa do NRC (1996) para PDR é subestimada em dietas à base de milho de alta umidade e de floculado para animais em terminação.

Utilizando os dados de consumo de PDR (Tabelas 21 e 22) e o de consumo de NDT determinado e corrigido para o consumo de MS (Tabela 8 e 22), verifica-se que, no tratamento com farelo de soja, o consumo de PDR foi de $9,9 \%$ do NDT e nos tratamentos com NNP foi de 12,1\%. Este maior consumo de PDR em relação ao NDT pode explicar a melhor eficiência alimentar nos tratamentos com PDR adequada (Tabela 22), confirmando que a exigência de PDR para esta dieta é por volta de $13 \%$ do NDT, valor este sugerido pelo NRC (1996).

Os GPV observados em relação aos preditos, menor entre EDG e PMDG, pelos dois modelos estão apresentados nas Figuras 12 (animais de todos os tratamentos), 13 (animais do tratamento com FS) e 14 (animais dos tratamentos com NNP).

A relação dos GPV observados e os preditos pelos modelos NRC (1996) e CNCPS v.4.0 (Fox et al. 2000), sendo utilizada a estimativa limitante (menor) entre EDG e PMDG para os animais de todos os tratamentos, observou-se as equações GPV $_{\text {Obs }}=0,6846+0,3314 \times G P V_{\text {Pred }}$ com $u m R^{2}$ de 0,32 e $N=26$ (NRC, 1996) e $\mathrm{GPV}_{\text {Obs }}=0,5804+0,4214 \times \mathrm{xPV}_{\text {Pred }}$ com um $\mathrm{R}^{2}$ de 0,39 e $\mathrm{N}=26$ (CNCPS). 


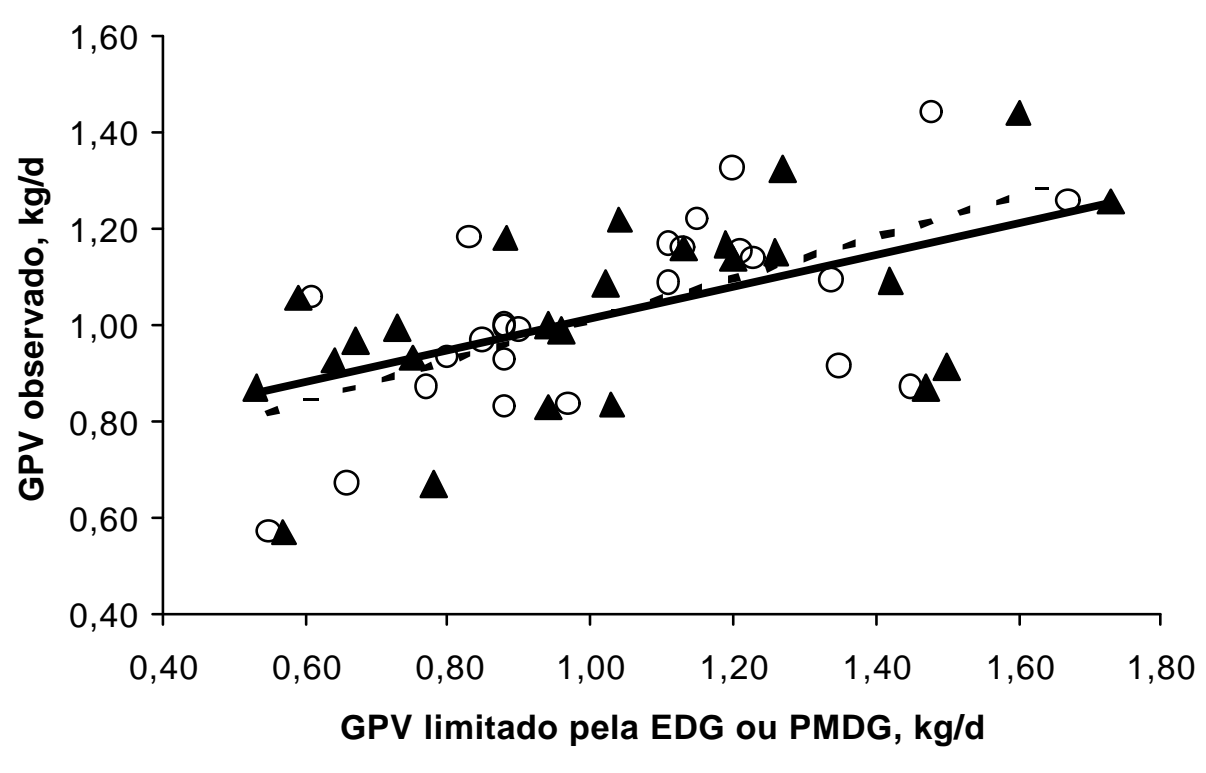

$\Delta \quad \mathrm{NRC} \quad \mathrm{O}$ CNCPS $\longrightarrow$ Linear (NRC) - - - Linear (CNCPS)

Figura 12 - Relação entre ganho de peso vivo (GPV) observado e o predito pela energia disponível para ganho (EDG) ou proteína metabólica disponível para ganho (PMDG) em kg/d, através do NRC (•) ou CNCPS (o), para animais alimentados com fontes nitrogenadas.

Dividindo os animais por tratamento, obteve-se para os animais suplementados com farelo de soja (deficiente em PDR) as equações GPV $_{\text {Obs }}=$ $0,4049+0,4393 \times G P V_{\text {Pred }}$ com um $R^{2}$ de 0,57 e $N=9(N R C, 1996)$ e $G V_{\text {Obs }}=$ $0,4298+0,4448 \times G P V_{\text {Pred }}$ com um $R^{2}$ de 0,57 e $N=9$ (CNCPS). Para os animais suplementados com NNP (PDR ajustada), observou-se as equações $\mathrm{GPV}_{\text {Obs }}=0,7135+0,3925 \times$ GPV $_{\text {Pred }}$ com um $R^{2}$ de 0,67 e $\mathrm{N}=17(\mathrm{NRC}, 1996) \mathrm{e}$ $\mathrm{GPV}_{\text {Obs }}=0,6192+0,4685 \times \mathrm{GPV}_{\text {Pred }}$ com um $\mathrm{R}^{2}$ de 0,55 e N = 17 (CNCPS). 


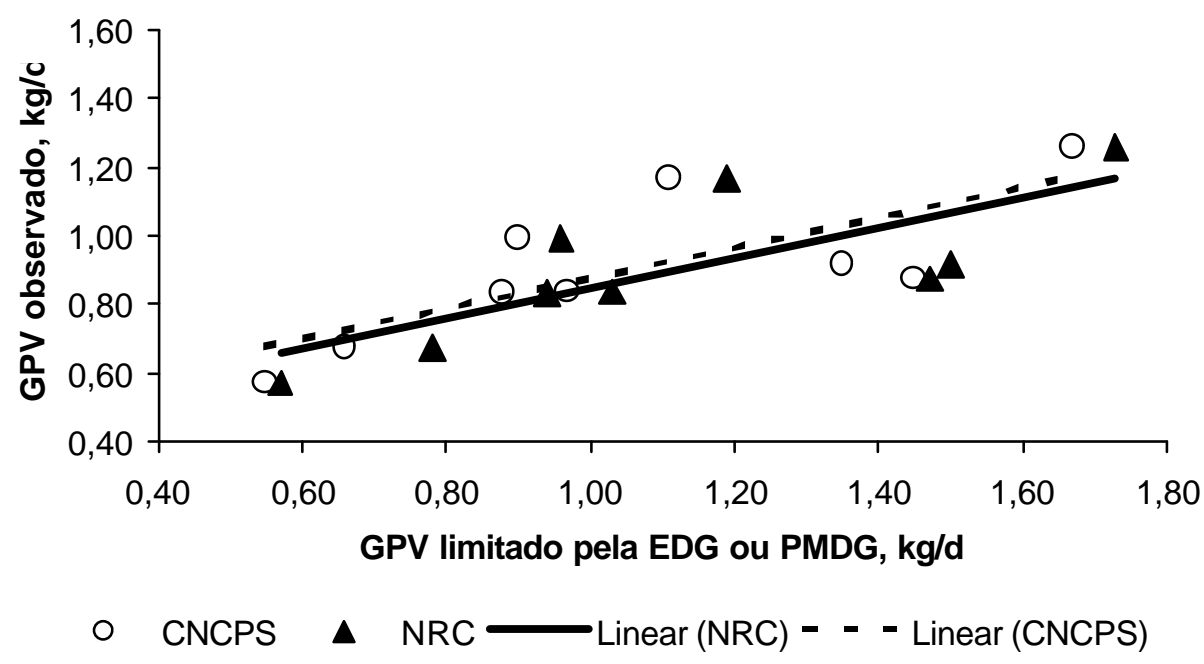

Figura 13 - Relação entre ganho de peso vivo (GPV) observado e o predito pela energia disponível para ganho (EDG) ou proteína metabólica disponível para ganho (PMDG) em kg/d, através do NRC (•) ou CNCPS (o), para animais com dieta deficiente em PDR (Tratamento FS).

Observando as Figuras 12, 13 e 14, verifica-se que os modelos explicam muito pouco ( $R^{2}$ baixo) do GPV dos animais alimentados com dietas deficientes ou não em PDR (Figura 12). Quando os animais são separados por tratamentos (PDR), os modelos explicam mais o GPV (maior $R^{2}$; Figuras 13 e 14). Verifica-se que, nos tratamentos com NNP (Figura 14), os modelos subestimaram o GPV (maior intercepto) mais que no tratamento com FS (Figura 13). 


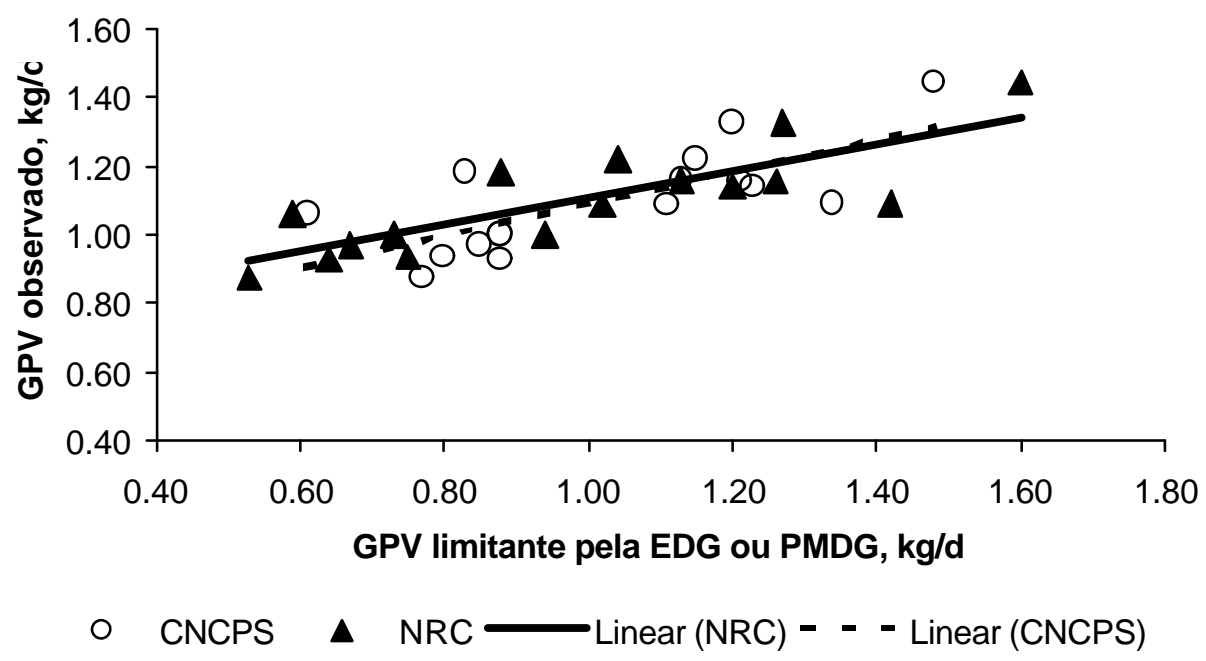

Figura 14 - Relação entre ganho de peso vivo (GPV) observado e o predito pela energia disponível para ganho (EDG) ou proteína metabólica disponível para ganho (PMDG) em kg/d, através do NRC (•) ou CNCPS (o), para animais com dieta PDR ajustadas (via NNP).

Block et al. (2001), avaliando o modelo do NRC (1996) nível 1 e 2 utilizando novilhos (Angus, Charolês e Hereford) em terminação, observaram um coeficiente de determinação $\left(R^{2}\right)$ de 0,66 e 0,64 para os níveis 1 e 2, respectivamente, na análise de regressão do GPV predito em relação ao observado. Esses valores estão próximos dos observados na atual simulação (Figuras 13 e 14), quando os animais foram divididos por tratamentos (PDR). Os autores Block et al., 2001) concluíram que o modelo do NRC (1996) não estimou com acurácia o GPV dos animais.

Block et al. (2001) comentaram que o modelo (NRC, 1996) prediz o consumo de MS dos animais (Bos taurus) em terminação, condizendo com a mesma observação na atual avaliação, em animais da raça Holandesa (Tabela 25). No entanto, o desempenho predito pelo modelo foi superestimado em 
relação ao observado (Tabela 25), discordando dos resultados de Block et al. (2001), os quais foram subestimados.

Tedeschi (2001), suplementando bovinos de corte com uréia e Optigen ${ }^{\circledR}$ (fonte de NNP de suposta liberação gradativa de N) ou combinações de ambas, observou a equação de $\mathrm{GPV}_{\text {Obs }}=270,8+0,819 \times \mathrm{xPV}_{\text {Pred }}(\mathrm{g} / \mathrm{d}) \mathrm{com}$ um $R^{2}$ de 0,91 e $N=20$ (CNCPS - Fox et al. 2000). O autor observou um coeficiente de determinação $\left(R^{2}\right)$ superior ao da atual avaliação. Talvez, devido a dieta, que na fase de crescimento foi silagem de milho (mais de $95 \%$ ), a fonte nitrogenada, minerais e vitaminas e, na fase de terminação, utilizou-se silagem de milho $(6,5 \%)$, feno $(7,0 \%)$, milho $(82,2 \%)$, a fonte nitrogenada, minerais e vitaminas, ou devido, aos animais utilizados, Angus (mais informações), ou possivelmente devido ao fato da determinação da composição corporal (\% de gordura), a qual é utilizada para ajustar as equações dos modelos, uma vez que, no atual experimento esta composição (\% de gordura) foi estimada visualmente. Esses fatores podem estar atuando conjuntamente.

Com base no exposto, pode-se inferir que para obter uma boa estimativa de desempenho, quando são utilizados estes modelos (NRC, 1996 e CNCPS - Fox et al., 2000) é necessário que o CMS e a composição corporal (\% de gordura) sejam avaliados ou estimados com uma certa veracidade.

É de suma importância salientar que os modelos "funcionam" tão melhor quanto mais próximos tiverem das condições em que foram feitos (banco de dados utilizado), não tendo um modelo "melhor ou pior" do que outro e sim, um modelo mais próximo ou distante das condições em que foram feitos (Tedeschi, L.O. Comunicação pessoal, 2002).

\subsection{Conclusões}

Quando as exigências em PDR são atendidas com o uso de uréia ou amiréia, em dietas com alto teor de concentrados, proporcionam 
desempenhos melhores do que utilizar uma fonte de proteína verdadeira, mesmo que esta seja de alto valor biológico (farelo de soja) sem atender as exigências em PDR.

A amiréia promove resultados similares aos da uréia convencional no consumo de matéria seca, ganho de peso e conversão alimentar.

O bagaço de cana-de-açúcar in natura promove desempenho satisfatório quando utilizado como única fonte de volumoso ( $20 \%$ da MS) em dietas com alto teor de concentrado ( $80 \%$ da MS).

O NRC (1996) e CNCPS (Fox et al., 2000) superestimaram o consumo de MS de animais da raça Nelore. Utilizando o consumo de MS observado, os modelos predizem razoavelmente o desempenho dos animais, principalmente se as exigências de PDR forem atendidas. Em contrapartida, o NRC subestimou muito o GPV de animais da raça Nelore suplementados com NNP. 


\section{SUBSTITUIÇÃO PARCIAL DO FARELO DE SOJA POR URÉIA OU AMIRÉIA, EM DIETAS CONTENDO BAGAÇO DE CANA-DE-AÇÚCAR HIDROLISADO, SOBRE O DESEMPENHO DE BOVINOS CONFINADOS EM TERMINAÇÃO}

\section{Resumo}

Oitenta e um machos, não castrados, das raças Nelore (27), Canchim (27) e Holandesa (27), com peso médio inicial de $360 \mathrm{~kg}$ e idade média de 18 meses, foram utilizados para avaliar a substituição de uma fonte de proteína verdadeira (farelo de soja), por uréia ou amiréia (fonte de nitrogênio não protéico de suposta liberação gradativa) sobre o desempenho de bovinos confinados. O delineamento experimental foi o de blocos inteiramente ao acaso com três animais por baia e nove baias por tratamento. Os blocos foram arranjados pelo peso inicial e raça. Os tratamentos foram: 1) farelo de soja (FS);

2) uréia e 3) amiréia (A-150S), com uma relação de $50 \%$ de volumoso (45\% de bagaço de cana-de-açúcar hidrolisado e $5 \%$ de bagaço in natura) e $50 \%$ de concentrado na matéria seca. O consumo de MS foi 8,99; 7,43 e 7,69 kg/dia, o ganho de peso vivo foi 0,$983 ; 0,368$ e $0,404 \mathrm{~kg} / \mathrm{dia}$ e a conversão alimentar foi 9,56; 20,14 e 19,54 kg MS/kg de ganho para os tratamentos farelo de soja, uréia e amiréia, respectivamente. $O$ tratamento $F S$ apresentou maior $(P<0,01)$ consumo de matéria seca e ganho de peso e melhor conversão alimentar que os tratamentos uréia e A150S. Os tratamentos uréia e A-150S não diferiram $(P>0,05)$ entre si. 


\section{PARCIAL REPLACEMENT OF SOYBEAN MEAL BY UREA OR STAREA IN FEEDLOT BEEF CATTLE DIETS}

\section{Summary}

Eighty-one yearling (27 Nelore, 27 Canchim and 27 Holstein), with $360 \mathrm{~kg}$ of initial body weight, were used to evaluate the effects of nitrogen sources on performance of feedlot cattle. Experimental treatments were: 1) soybean meal, 2) urea and 3) starea. Diets were composed of $50 \%$ concentrate and $50 \%$ forage ( $45 \%$ hydrolyzed sugarcane bagasse $+5 \%$ in natura sugarcane bagasse). DMl, average daily gain and fed efficiency were 8.99; 7.43 and 7.69 $\mathrm{kg} /$ day, $0.983,0.368$ and $0.404 \mathrm{~kg} /$ day, $9.56,20.14$ and $19.54 \mathrm{~kg} \mathrm{DM} / \mathrm{kg}$ gain for soybean meal, urea and starea treatments, respectively. Soybean meal had higher DMI, average daily gain and feed efficiency $(P<0.01)$ compared to urea and starea treatments. There was no difference $(P>0.05)$ between urea and starea treatments.

\subsection{Introdução}

Dietas com baixa energia apresentam menor capacidade de resposta com o uso de nitrogênio não protéico (ex. uréia), podendo não ocorrer um sincronismo entre a disponibilidade ruminal de $\mathrm{NH}_{3}$ e energia, uma vez que a amônia ruminal é utilizada para o crescimento microbiano e este crescimento é dependente da disponibilidade de energia (Owens \& Zinn, 1988). Este fato poderia ser amenizado com uma fonte de nitrogênio não protéico com liberação mais lenta de amônia (ex. amiréia).

O uso de nitrogênio não protéico tem a vantagem de ser mais econômico que uma fonte de proteína verdadeira na mesma quantidade de nitrogênio. Entretanto, a fonte de nitrogênio não protéico mais utilizada (uréia) 
apresenta uma rápida liberação de amônia no rúmen que, dependendo da quantidade utilizada, pode exceder a capacidade de utilização pelos microrganismos. Conseqüentemente, este excesso de amônia é absorvido pela parede ruminal e pode-se tornar tóxica para ao animal, devido a incapacidade do fígado em metabolizá-la. Porém, do que é metabolizado, a maior parte é transformada em uréia, envolvendo gasto de energia. Essa uréia circulante poderá reciclar para o rúmen, via parede ruminal ou saliva ou ser excretada via urina.

A utilização de uma fonte de nitrogênio não protéico com uma liberação lenta de amônia teria vantagens de aumentar a disponibilidade de amônia para síntese microbiana e reduzir problemas com toxidez (Bartley \& Deyoe, 1975).

O processo de extrusão consiste na união da uréia com a molécula de amido gelatinizado através da exposição a condições de pressão, temperatura e umidade, por um determinado tempo, obtendo-se assim, a amiréia. O benefício proposto por esta prática seria um aumento na velocidade de fermentação do amido no rúmen aliado à redução da intensidade de liberação de amônia oriunda da uréia, compatibilizando os dois fatores para a síntese de proteína microbiana (Silva et al., 1994 e Seixas et al., 1999).

O bagaço tratado sob pressão e vapor, quando utilizado em dietas para confinamentos, tem proporcionado desempenhos satisfatórios (Lanna \& Boin, 1990; Nussio et al., 1990; Santos, 1991; Nussio, 1993 e Rabelo, 2002). No entanto, para se ter condições ruminais adequadas é necessário adicionar uma fonte de fibra íntegra, como o bagaço in natura (Nussio, $1993 \mathrm{e}$ Rabelo, 2002) ou ponta de cana picada (Hausknecht, 1996).

O objetivo deste trabalho foi comparar a substituição de proteína verdadeira (farelo de soja) por uréia ou amiréia (fonte de nitrogênio não protéico de suposta liberação lenta de nitrogênio), tendo o bagaço de cana-de-açúcar tratado sob pressão e vapor como principal volumoso (45\% da MS), sobre o desempenho de bovinos confinados em terminação. 


\subsection{Material e métodos}

\subsubsection{Animais e instalações experimentais}

Foram utilizados 81 machos não castrados (27 Nelore, 27 Canchim e 27 Holandês), com peso médio inicial de $360 \mathrm{~kg}$ e média de 18 meses de idade.

O experimento foi conduzido nas instalações no Centro de Produção Intensiva de Bovinos de Corte do Departamento de Zootecnia ESALQ-USP, onde os animais foram alojados em baias $(3 \times 11 \mathrm{~m})$ cobertas, com piso, cocho e bebedouro de concretos, sendo distribuídos três animais por baia, em um total de 27 baias. O período experimental foi realizado durante 0 período de fevereiro a maio de 2000.

Os animais foram previamente everminados e receberam uma dose de complexo vitamínico $\mathrm{ADE}$ na fase de adaptação às dietas e às instalações experimentais.

\subsubsection{Tratamentos}

Os animais foram alimentadas com dietas contendo bagaço de cana-de-açúcar tratado sob pressão e vapor (BTPV; 45\%) e bagaço in natura (BIN; $5 \%$ ) como volumoso (50\%) e $50 \%$ de concentrado (Tabela 26 ), sendo que os tratamentos experimentais foram feitos pela substituição da fonte de proteína verdadeira (farelo de soja - FS), por uréia ou amiréia (A-150S - fonte de nitrogênio não protéico de suposta liberação lenta de nitrogênio).

As fontes de uréia utilizadas foram: a uréia (adubo convencional) e a uréia (adubo convencional) extrusada, sendo o milho, a fonte 
de amido utilizada (Amiréia $150 \mathrm{~S}^{\circledR}$, Pajoara indústria e comércio, Campo Grande, MS).

Tabela 26. Composição em ingredientes e composição química das dietas (\% da MS).

\begin{tabular}{lccc}
\hline \multirow{2}{*}{ Ingredientes } & \multicolumn{3}{c}{ Tratamentos } \\
\cline { 2 - 4 } & $\mathrm{FS}$ & Uréia & $\mathrm{A}-150 \mathrm{~S}$ \\
\hline Bagaço hidrolisado (BTPV) & 45,0 & 45,0 & 45,0 \\
Bagaço in natura (BIN) & 5,0 & 5,0 & 5,0 \\
Milho moído & 19,0 & 20,0 & 20,0 \\
Polpa cítrica & 13,0 & 24,0 & 22,2 \\
Farelo de soja (FS) & 17,0 & 3,0 & 3,0 \\
Uréia & - & 2,0 & - \\
Amiréia 150S (A-150S) & - & - & 3,7 \\
Mistura mineral & & 0,63 & 0,75 \\
Monoamônio fosfato (MAP) & 0,07 & 0,32 & 0,30 \\
Composição química & & & \\
MS (\% da matéria natural) & 62,4 & 63,9 & 62,1 \\
Proteína bruta & 12,5 & 11,3 & 11,4 \\
Fibra em detergente neutro & 39,3 & 38,4 & 39,2 \\
Fibra em detergente ácido & 35,6 & 36,7 & 36,8 \\
Matéria mineral & 5,8 & 5,4 & 5,8 \\
Extrato etéreo & 1,9 & 2,0 & 1,9 \\
\hline
\end{tabular}

1 Composição no tratamento FS (farelo de soja)= NNP=1,74\%; Ca=0,012\%; $P=4 \% ; S=2,7 \% ; C b=750 p p m$; $\mathrm{I}=40 \mathrm{ppm} ; \mathrm{Mn}=1500 \mathrm{ppm} ; \mathrm{Se}=10 \mathrm{ppm} ; \mathrm{Zn}=2250 \mathrm{ppm} ;$ vit.A=300000Ul/kg; vit.D3=20000Ul/kg; Vit.E=3500Ul $/ \mathrm{kg}$; Rumensin $=2 \%$. Tratamentos uréia e $A-150 S=N N P=4,35 \% ; C a=0,012 \% ; P=10 \% ; S=7,1 \% ; M g=2,0 \% ; C b=750$ ppm; I=40 ppm; Mn=1500 ppm; Se=10 ppm; Zn=2250 ppm; vit.A=300000 Ul/kg; vit.D3=20000 Ul/kg; Vit.E=3500 Ul/kg; Rumensin=2\%. 
Os tratamentos (Tabela 26) foram formulados para resultarem em dietas isoprotéicas e isoenergéticas, utilizando o programa do NRC (1996) de bovinos de corte. Composição em ingredientes e química das dietas então apresentados nas Tabela 26 e 27.

Os concentrados foram misturados previamente em um misturador horizontal (marca Lucato, capacidade de $250 \mathrm{~kg}$ ). Na hora do fornecimento da alimentação, o bagaço tratado a pressão e vapor, o bagaço in natura e o concentrado, nas suas respectivas proporções, foram misturados utilizando um vagão para ração completa (marca Siltomac, com capacidade de $1800 \mathrm{~kg}$ ) e fornecidos como ração completa diariamente (18h).

Tabela 27. Composição das frações nitrogenadas das dietas (\% da MS).

\begin{tabular}{lccc}
\hline \multirow{2}{*}{ Itens $^{2}$} & \multicolumn{3}{c}{ Tratamentos $^{1}$} \\
\cline { 2 - 4 } & FS & Uréia & A-150S \\
\hline PB, \% & 12,5 & 11,3 & 11,4 \\
PBsol, \% da PB & 13,2 & 49,1 & 48,6 \\
PBIDN, \% da PB & 42,3 & 20,9 & 22,4 \\
PBIDA, \% da PB & 14,2 & 17,4 & 15,9 \\
PDR $^{3}, \%$ da PB & 67,7 & 75,9 & 75,9 \\
PDR, \% da MS & 8,5 & 8,6 & 8,7 \\
\hline
\end{tabular}

${ }^{1} \mathrm{FS}$ =farelo de soja; $\mathrm{A}-150 \mathrm{~S}=$ amiréia;

2 PB=proteína bruta. PBsol= proteína bruta solúvel; PBIDN= proteína bruta insolúvel em detergente neutro; PBIDA= proteína bruta insolúvel em detergente ácido; $P D R=$ proteína bruta degradável no rúmen;

${ }^{3}$ Calculada utilizando os valores de tabela do NRC (1996) nível 1; para BIN usou 25\% e para o BTPV usou $47,8 \%$ PDR (Fox et al, 2000).

\subsubsection{Período experimental}

O período experimental teve duração de 98 dias, sendo os primeiros 14 dias destinado ao processo de adaptação dos animais æ̀s 
instalações e à dietas experimentais, e o restante do período foi segmentado em três sub-períodos de 28 dias.

\subsubsection{Colheita de dados referentes ao consumo de matéria seca}

Os dados de consumo de MS por animal/dia foram obtidos através da diferença entre a quantidade de MS fornecida e a MS da sobra. A quantidade de MS fornecida era determinada diariamente com a utilização de balança detrônica do vagão para ração completa. A quantidade de alimento oferecido foi ajustada diariamente com base nas sobras do dia anterior, objetivando um mínimo possível de sobra, sendo esta registrada semanalmente.

Durante o período experimental, foram amostrados as sobras e os alimentos oferecidos uma vez por semana, as quais foram compostas por sub-período e tratamento.

As amostras foram conservadas congeladas a $-10^{\circ} \mathrm{C}$ até serem descongeladas e secas em estufas com ventilação forçada ( $\left.55^{\circ} \mathrm{C}\right)$ por 72 horas e, posteriormente, por 12 horas a $105^{\circ} \mathrm{C}$ para determinação de matéria seca de acordo com Silva (1990).

\subsubsection{Análise bromatológica das dietas e sobras}

Amostras do alimento oferecido e das sobras foram secas em estufas com ventilação forçada àtemperatura de $55^{\circ} \mathrm{C}$ por 72 horas e moídas em moinhos tipo Wiley (Marconi, Piracicaba, SP) primeiramente em peneira com crivos de $2 \mathrm{~mm}$ e após em peneiras com crivos de $1 \mathrm{~mm} \mathrm{e}$, posteriormente, por 12 horas a $105^{\circ} \mathrm{C}$ para determinação de matéria seca de acordo com Silva (1990); MM, EE e PB de acordo com AOAC (1990); FDN e 
FDA de acordo com o método de Van Soest et al. (1991), não seqüencial, utilizando amilase e sulfito de sódio nas determinações de FDN. A MO foi obtida pela subtração da MM da MS.

\subsubsection{Pesagem dos animais}

Os animais foram pesados no final do período de adaptação e no final de cada sub-período experimental. As pesagens dos animais foram feitas com jejum de 16 horas de alimento.

\subsubsection{Delineamento experimental e análise estatística}

O delineamento experimental utilizado foi 0 de blocos casualizados, sendo os blocos arranjados de acordo com peso inicial e raça, tendo três animais por baia e nove baias por tratamento. Os dados foram analisados pelo procedimento MIXED do programa estatístico SAS (1988). Foi utilizado o seguinte modelo estatístico:

$Y_{i j k}=M+B_{i}+F P_{j}+P_{k}+F P_{j} x P_{k}+E_{i j k}$

Onde:

$M=$ Média geral

$\mathrm{B}_{\mathrm{i}}=$ Efeito do bloco

$F P_{j}=$ Efeito da fonte protéica

$\mathrm{P}_{\mathrm{k}}=$ Efeito de período

$\mathrm{FP}_{\mathrm{j}} \mathrm{xP} \mathrm{P}_{\mathrm{k}}=$ Interações entre a fonte protéica e o período

$E_{i j k}=$ Efeito aleatório 
Este modelo foi utilizado para analisar todas as variáveis, exceto o consumo de matéria seca, onde se utilizou semana no lugar de período. $O$ efeito bloco foi considerado efeito aleatório.

Depois de detectada significância (teste F), as diferenças entre os tratamentos para as diversas variáveis analisadas foram verificadas através do teste Tukey utilizando o comando LSMEANS/PDIFF, considerando 5\% $(P<0,05)$ como nível de significância e até $10 \%$ como tendência $(P<0,10)$.

\subsection{Resultados e discussão}

Os dados de consumo de MS, ganho de peso vivo diário e conversão alimentar estão apresentados na Tabela 28. Observando a Tabela 28 não verifica-se diferenças $(P>0,10)$ entre os tratamentos contendo uréia ou amiréia. $O$ tratamento com farelo de soja apresentou um maior $(P<0,05)$ consumo de $\mathrm{MS}$, ganho de peso e também melhor $(\mathrm{P}<0,05)$ conversão alimentar (Tabela 28), comparado as fontes de nitrogênio não protéico (uréia ou amiréia).

Resultados semelhantes aos deste experimento foram observados por Schmidt et al. (1973) no ganho diário, quando compararam farelo de soja e amiréia, mas, diferem da maioria dos dados apresentados na literatura (Thompson et al., 1972 e Teixeira et al., 2000), os quais não verificaram alterações no ganho de peso diário entre farelo de soja, uréia e amiréia.

Revendo dez anos de pesquisa com amiréia, Bartley \& Deyoe (1975), sumarizaram diversos trabalhos totalizando 12 comparações de ganho de peso diário e conversão alimentar em novilhos em terminação recebendo uréia ou amiréia, e observaram que em nenhuma das avaliações ocorreram diferenças, sendo que as médias de todas as comparações de GPV foram 
iguais $\left(1,25 \mathrm{~kg}\right.$ animal $\left.{ }^{-1} \cdot \mathrm{d}^{-1}\right)$ para uréia e amiréia, estando de acordo com os resultados do atual experimento.

Os tratamentos com fontes de nitrogênio não protéico (uréia ou amiréia) foram inferiores quando comparados ao farelo de soja. Isto ocorreu, provavelmente, devido à falta de fibra efetiva nas dietas, reduzindo $\mathrm{opH}$ ruminal, a síntese de proteína microbiana (Allen, 1997) e, conseqüentemente, a quantidade de proteína metabólica, a qual deveria estar limitando o ganho (Tedeschi et al., 2000), juntamente com o menor aporte energético para o animal (menor síntese e eficiência da microbiota ruminal; Russell et al., 1992).

Algumas pesquisas têm sugerido que a substituição total de proteína verdadeira por NNP (uréia) pode resultar em uma redução na produção microbiana e na digestão, devido a limitações no crescimento microbiano, ocasionado por falta de peptídeos, aminoácidos e ácidos graxos voláteis de cadeira ramificada (Redman et al., 1980 e Tedechi, 2001). No atual experimento, essa substituição foi quase total (Tabela 26), resultando em desempenhos inferiores nos tratamentos em que o NNP substituiu o farelo de soja (Tabela 28).

A falta de sincronismo entre a liberação de $\mathrm{N}$ e carboidratos, associado a um consumo insuficiente de PNDR, são os dois fatores mais consideráveis quando ocorre uma redução no desempenho animal em dietas com a proteína baseada em suplementos de NNP (NRC, 1996). Observando a Tabela 26, verifica-se que os tratamentos uréia e amiréia apresentam poucos carboidratos rapidamente fermentáveis e uma baixa PNDR, o que pode ter promovido a redução no desempenho segundo o NRC (1996). Já a proteína do farelo de soja apresenta uma fração de PNDR, contribuindo para o "pool" de proteína metabolizável, o que pode ter proporcionando ganhos no tratamento farelo de soja superiores aos demais tratamentos (NNP). 
Tabela 28. Desempenho de bovinos de corte confinados suplementados com fontes nitrogenadas.

\begin{tabular}{lcccccc}
\hline \multirow{2}{*}{ Itens $^{2}$} & \multicolumn{3}{c}{ Tratamentos $^{1}$} & & \\
\cline { 2 - 4 } & FS & Uréia & A-150S & & EPM $^{3}$ \\
\hline Peso inicial, kg & 360,8 & 362,1 & 360,5 & 9,17 & 0,9621 \\
Peso final, kg & $443,2^{\mathrm{a}}$ & $392,8^{\mathrm{b}}$ & $394,5^{\mathrm{b}}$ & 10,17 & 0,0001 \\
CMS, kg/d & $8,99^{\mathrm{a}}$ & $7,43^{\mathrm{b}}$ & $7,69^{\mathrm{b}}$ & 0,16 & 0,0001 \\
$\quad$ \%PV & $2,24^{\mathrm{a}}$ & $1,97^{\mathrm{b}}$ & $2,04^{\mathrm{b}}$ & 0,06 & 0,0002 \\
$\quad$ g/kgPV 0,75 & $100,1^{\mathrm{a}}$ & $86,8^{\mathrm{b}}$ & $89,8^{\mathrm{b}}$ & 2,40 & 0,0001 \\
GPV, kg/d & $0,983^{\mathrm{a}}$ & $0,368^{\mathrm{b}}$ & $0,404^{\mathrm{b}}$ & 0,06 & 0,0001 \\
CA, kg MS/kg ganho & $9,58^{\mathrm{b}}$ & $20,14^{\mathrm{a}}$ & $19,54^{\mathrm{a}}$ & 1,39 & 0,0001 \\
\hline
\end{tabular}

$a, b=$ Letras diferentes nas linhas referem-se as médias que diferem entre si pelo teste Tukey $(P<0,05)$; as médias foram ajustadas pelos quadrados mínimos (LSMEANS);

${ }^{1} \mathrm{FS}=$ =farelo de soja; $\mathrm{A}-150 \mathrm{~S}=$ amiréia;

2 GPV=ganho de peso vivo; CMS=consumo de matéria seca; $C A=$ conversão alimentar;

${ }^{3}$ Erro Padrão da Média;

${ }^{4} \mathrm{P}=$ Probabilidade de haver efeito significativo entre tratamentos.

Os valores de fibra (FDN e FDA) são relativamente altos (Tabela 26), porém, o bagaço tratado por pressão e vapor reduz muito a efetividade da fibra (Castro, 1989 e Fox et al., 2000) e o bagaço in natura apresenta uma maior efetividade da fibra (Fox et al., 2000). Contudo, a quantidade de BIN na dieta (5\%) não foi suficiente para proporcionar um ambiente ruminal estável, o que, possivelmente, proporcionou um pior desempenho nos tratamentos com nitrogênio não protéico.

Faltando fibra efetiva, diminui a atividade de mastigação e, por conseguinte, a secreção de saliva e os seus tamponantes (bicarbonato e fosfato), que neutralizam os ácidos produzidos pela fermentação da matéria orgânica no rúmen. O balanço entre os ácidos produzidos na fermentação e a secreção de tamponantes é o maior determinante do $\mathrm{pH}$ ruminal, e este, por 
sua vez, pode acarretar baixos valores de consumo de MS, digestibilidade da fibra e produção microbiana (Allen, 1997).

DaSilva (1990), avaliando dietas contendo como alimento volumoso principal o bagaço de cana-de-açúcar tratado à pressão e vapor, concluiu que a inclusão do bagaço in natura não alterou o padrão de fermentação e a eficiência do processo fermentativo do rúmen.

A inclusão de cana picada melhorou o consumo, o ganho de peso e a conversão alimentar em relação à inclusão do bagaço in natura $(P<0,05)$, em dietas contendo como alimento volumoso principal o bagaço de cana-deaçúcar tratado à pressão e vapor (Hausknecht, 1996), demonstrando que, em algumas situações, o bagaço in natura não consegue proporcionar um ambiente ruminal estável.

Russell et al. (1992) sugeriram que, quando a FDN de forragem na dieta diminui de $20 \%$, o crescimento da produção microbiana é reduzida em $2,5 \%$ para cada $1 \%$ de redução na FDN. Este ajuste foi incorporado no NRC (1996) e no CNCPS (Fox et al., 2000). No entanto, Armentano \& Pereira (1997) demonstraram que a utilização da FDN para medir a fibra (efetividade) dos alimentos é problemática em duas classes de alimentos: forragens processadas em diferentes formas físicas e subprodutos com alto teor de fibra. Os volumosos do atual experimento estão dentro destas classes de alimentos. Allen (1996) sugeriu aumentar a FDN (\% da MS) da dieta quando incluir subprodutos na mesma.

O BTPV apresenta uma elevada acidez, com um valor de $\mathrm{pH}$ normalmente entre 2,8 a 3,7 (Burgi, 1985), um tamanho reduzido de partícula e uma alta friabilidade, proporcionando uma baixa atividade de ruminação e resultando em uma baixa produção de saliva (Castro, 1989). Além disso, a presença de carboidratos solúveis prontamente fermentescíveis no BTPV, que são rapidamente degradados no rúmen, produz grandes quantidades de ácidos graxos voláteis (AGV) que fazem com que o $\mathrm{pH}$ decresça, prejudicando 0 crescimento microbiano (Lanna \& Boin, 1990). 
Utilizando dietas à base de BTPV, Costa (1987) observou que o $\mathrm{pH}$ permaneceu abaixo de 6,0 por mais de 6 horas. Castro (1989) também verificou que dietas com BTPV apresentam um ambiente ruminal inadequado para uma degradação eficiente da fração fibrosa.

Além disso, Caielli et al. (1997), utilizando BTPV com diferentes procedimentos de fabricação e dois teores (30 e 50\% da MS) em dietas de bovinos em confinamento, concluíram fatores erráticos no processo operacional do bagaço, tais como: tempo de permanência no cozedor, controle de temperatura, umidade inicial do bagaço, lavagem do material solúvel, etc., podem afetar sua qualidade assim como o processo de digestão, influenciando o consumo, particularmente quando compõem rações em porcentagens acima de $40 \%$ da MS. No atual experimento o BTPV representava $45 \%$ da MS da dieta (Tabela 26).

O consumo de matéria seca $\left(100,1 \mathrm{~g} / \mathrm{kgPV}^{0,75}\right)$, o ganho de peso vivo $(0,983 \mathrm{~kg} / \mathrm{d})$ e a conversão alimentar $(9,58 \mathrm{~kg} \mathrm{MS} / \mathrm{kg}$ de ganho) dos animais suplementados com farelo de soja (Tabela 28) estão próximos dos observados por outros autores (Lanna \& Boin, 1990; Nussio et al., 1990; Santos, 1991; Nussio, 1993 e Rabelo, 2002). Em confinamentos comerciais que utilizaram o BTPV, a conversão alimentar observada foi de 9,3 a 21,6, com média de 12,6 (Burgi, citado por Nussio, 1993), o que abrangeria os valores observados nos tratamentos com uréia e amiréia (20,14 e 19,54 kg MS/kg de ganho, respectivamente) do atual experimento.

Nussio (1993), utilizando $50 \%$ de BTPV e $5 \%$ de BIN e Rabelo (2002) utilizando $45 \%$ de BTPV e $5 \%$ de BIN, verificaram ganhos superiores aos observados nos tratamentos com NNP (uréia e amiréia), próximos aos do tratamento com farelo de soja. Isto se deve, provavelmente, à fonte de proteína verdadeira (mais de $10 \%$ da MS) que estes autores utilizaram, pois não tinham o NNP como a principal fonte protéica, como utilizado no atual experimento. Isso nos dá um indicativo de que faltou proteína metabolizável nos tratamentos com NNP (uréia e amiréia), devido à provável redução na síntese de proteína 
microbiana em decorrência da falta de fibra efetiva, já que estes tratamentos apresentavam baixa PNDR e dependiam, principalmente, da proteína microbiana.

\subsection{Conclusões}

A substituição de farelo de soja por fontes de nitrogênio não protéico (uréia ou amiréia), em dietas contendo $45 \%$ de BTPV e $5 \%$ de BIN como volumoso, reduz o desempenho de bovinos na fase de terminação.

A amiréia não apresentou vantagens à uréia no consumo de matéria seca, ganho de peso e conversão alimentar em animais confinados na fase de terminação.

O uso de $45 \%$ de BTPV e $5 \%$ de BIN como volumoso parece não ser suficiente para manter uma estabilidade ruminal adequada, quando se utiliza suplementação com NNP. 


\section{COMPARAÇÃO ENTRE DETERMINAÇÃO DE CROMO POR FLUORESCÊNCIA DE RAIOS X E INDICADORES INTERNOS PARA ESTIMAR A DIGESTIBILIDADE DOS NUTRIENTES EM NOVILHOS NELORE, ALIMENTADOS COM DIETAS COM ALTO TEOR DE CONCENTRADO E FONTES NITROGENADAS}

\section{Resumo}

Seis machos da raça Nelore, não castrados, com peso médio inicial de $420 \mathrm{~kg}$, foram utilizados para avaliar o óxido de cromo, analisado por fluorescência de raios $X$, como indicador externo de digestibilidade no trato gastrintestinal. $O$ óxido de cromo foi comparado com os indicadores internos de indigestibilidade: FDN indigestível (FDNi) incubada in vitro por 144 horas e a lignina detergente ácido e a colheita total de fezes. Estimou-se os coeficientes de digestibilidade da MS, MO, FDN, FDA, PB e EE. As dietas experimentais foram formuladas com três fontes de nitrogênio: 1) farelo de soja, em uma dieta deficiente em PDR; 2) uréia; 3) amiréia (fonte de nitrogênio não protéico de suposta liberação gradativa), ambas em dietas adequadas em PDR. As dietas eram compostas de $80 \%$ de concentrado e $20 \%$ de volumoso (bagaço de canade-açúcar in natura) na matéria seca. A estimativa da digestibilidade utilizando o óxido de cromo apresentou resultados similares $(P>0,05)$ à colheita total de fezes. O mesmo foi observado com a lignina no tratamento com farelo de soja (deficiente em PDR), mas naqueles com uréia e amiréia, os coeficientes de digestibilidade foram subestimados $(P<0,05)$. A FDNi subestimou $(P<0,05)$ a digestibilidade em todas as frações estudadas independente do tratamento. A fluorescência de raios-X demonstrou ser uma técnica promissora na 
determinação do cromo. Os indicadores internos, FDNi incubada in vitro por 144 horas e a lignina em detergente ácido não representaram a fração indigestível da dieta.

\section{COMPARATION OF CROMIUM OXIDE DETERMINATION BY X- RAY FLUORESCENCE WITH INTERNAL MARKERS OF NUTRIENT DIGESTIBILITY IN BEEF CATTLE FED HIGH GRAIN DIETS AND DIFFERENT NITROGEN SOURCE}

\section{Summary}

Six Nellore bulls, with initial body weight of $420 \mathrm{~kg}$, were used to evaluate cromium oxide determined by X-ray fluorescence as an external indicator of digestibility. Cromium oxide was compared to internal indicators: indigestible NDF (NDFi) incubated in vitro for 144 hours and acid detergent lignin and total feces collection. Digestibility coefficients of DM, OM, NDF, ADF, $\mathrm{CP}$ and $\mathrm{EE}$ were estimated. Experimental diets were formulated with one of three nitrogen sources: 1) soybean meal, in a RDP deficient diet; 2) urea; 3) starea (non protein nitrogen source supposedly of slow release), both diets with adequate RDP. Experimental diets were composed of $80 \%$ of concentrate and $20 \%$ of forage (in natura sugar cane bagasse) on dry matter basis. Digestibility estimation by using cromium oxide showed similar $(P>0.05)$ results with total feces collection. Lignin determination was similar to feces collection when soybean was used; however, when urea and starea were fed, the digestibility coefficient were underestimated $(P<0.05)$. NDFi underestimated $(P<0.05)$ digestibility for all nitrogen sources. X-ray fluorescence showed to be a promising technique for cromium determination. Internal markers, NDFi incubated in vitro for 144 hours and the acid detergent lignin did not estimated the indigestible portion of the diet. 


\subsection{Introdução}

A digestibilidade é um dos parâmetros mais importantes para a avaliação do valor nutritivo de um alimento. A determinação da digestibilidade através de ensaios de alimentação, envolvendo colheita total de fezes, requer controle rigoroso das ingestões e excreções, o que a torna trabalhosa e onerosa, além de, em determinadas circunstâncias, este controle é praticamente impossível de ser realizado.

Várias substâncias são sugeridas como indicador de fluxo, porém nenhuma delas é perfeita, mas apresentam características suficientemente adequadas para fornecer dados significativos. Por esta razão, a procura de indicadores ideais constitui um dos assuntos de grande interesse na pesquisa de técnicas que facilitem estudos de nutrição animal.

A busca de métodos mais simples para a determinação da digestibilidade conduziu ao emprego dos indicadores ou marcadores que podem proporcionar uma série de informações, incluindo: a quantidade consumida de alimento ou nutriente específico; a taxa de passagem da digesta através de todo ou parte do trato digestivo e a digestibilidade de todo alimento ou de nutrientes específicos (Oliveira et al., 1991).

A digestibilidade in vivo é influenciada por efeitos associativos, nível de consumo, taxa de passagem e interações destes fatores e, por isso, freqüentemente é difícil imitar essas condições in vitro (Conchran et al., 1986). Nessas condições, a estimativa da digestibilidade intermediada por indicadores pode ser desejável (Van Soest, 1994). Constituintes naturais da dieta que apresentam baixa digestibilidade têm sido utilizados como indicadores. Os indicadores internos apresentam a vantagem de já estarem presentes no alimento e, de modo geral, permanecem distribuídos na digesta durante o processo de digestão e excreção (Piaggio et al., 1991).

Fregadolli et al. (2000) utilizaram a FDNi por incubação ruminal de 192 horas como indicador e Ítavo et al. (2000) com incubação ruminal de 
144 horas, não obtiveram boas estimativas de digestibilidade. Segundo Piaggio et al. (1991) as variações existentes na recuperação de indicadores indigestíveis por incubação ruminal estão associadas à perdas de partículas ocorridas pelos poros dos sacos de náilon. Contrariando esta observação, Zeoula et al. (2001) observaram que a FDNi (incubada no rúmen por 8 horas) apresentou bons resultados na estimativa da digestibilidade em ovinos. Outro problema apontado por Lippke et al. (1986) foi que boa parte da variabilidade dos resultados obtidos com indicadores internos indigestíveis pode ser atribuída à falta de padronização no método de determinação. $O$ método in vitro tem a vantagem de ser um método mais simples e econômico, uma vez que não há necessidade de manter animais fistulados (Freitas et al., 2002).

$O$ erro de amostragem pode ser reduzido se um componente indigestível de alta porcentagem na matéria seca puder ser encontrado. Neste sentido, tem sido sugerido que as frações fibrosas indigestíveis do alimento sejam utilizadas com este propósito (Lippke et al., 1986). Os componentes da parede celular estão sendo avaliados como indicadores internos como a fibra em detergente neutro (FDN) indigestível (Conchran et al., 1986; Nelson et al., 1990; Berchielli et al., 2000 e Detmann et al., 2001), ressaltando a necessidade de maiores informações. Quanto ao uso de lignina em detergente ácido (LDA), esta apresenta a vantagem de ser um método fácil de rápida análise, barato e rotineiro em laboratórios de análise de alimentos. Recuperações positivas e incompletas foram reportadas por Muntifering (1982), Fahey \& Jung (1983) e Van Soest (1994).

O óxido de cromo tem sido o indicador mais amplamente utilizado para determinação da excreção fecal, apresentando as vantagens de ser barato, facilmente incorporado à dieta e analisado com relativa facilidade (Lima et al., 1980 e Merchen, 1988). O procedimento tradicional de utilização consiste na aplicação de duas doses diárias, de mesmo peso em intervalos de tempos definidos, com colheitas concomitantes (Hopper et al., 1978), sendo necessário um período de adaptação de 5 a 7 dias, anterior ao início das 
colheitas fecais, a fim de se alcançar um platô de concentração nas fezes (Owens \& Hanson, 1992). Tanto a acurácia como a precisão desta técnica tem sido demonstrada (Prigge et al., 1981 e Perreira et al., 1983).

Alguns trabalhos (Mendes junior, 1999; Oliveira Junior, 1999; Ribeiro, 1999; Imaizumi, 2000; Golçalves, 2000; Oliveira, 2001b e Rabelo, 2002) não conseguiram recuperações satisfatórias de cromo, apresentando coeficientes de digestibilidade baixos ou até negativos, não sendo possível determinar quais foram as possíveis causas. A análise utilizada nestes trabalhos foi a descrita por Fenton \& Fenton (1979) com leitura em espectrofotômetro de absorção atômica e por Silva (1990). Estas metodologias envolvem diversas etapas de extrações químicas implicando gasto de tempo e reagentes, podendo aumentar o erro analítico.

A técnica analítica nuclear de fluorescência de raios $X$ com dispersão de energia (EDXRF) tem sido utilizada para a avaliação qualiquantitativa da composição química em vários tipos de amostras, de interesse agropecuário, agroindustrial, geológico e ambiental. Esta técnica, por ser não destrutiva e instrumental e por permitir a análise de vários elementos simultaneamente, de modo rápido e a baixo custo, tem um elevado potencial de aplicação em várias áreas, onde há necessidade de correlação entre os elementos essenciais e tóxicos. Entre as vantagens da fluorescência de raios $\mathrm{X}$ para a análise química de elementos pode-se citar: (a) adaptabilidade para automação, (b) análise rápida multielementar, que é muito importante devido a interdependência entre os micronutrientes nos sistemas biológicos, (c) preparação simplificada da amostra e (d) limite de detectabilidade dentro do exigido por muitas amostras biológicas (Nascimento Filho, 1999).

A excreção fecal do cromo pode variar entre dias e entre turnos (Lima et al., 1980 e Oliveira et al, 2001). Para amenizar este problema, Oliveira et al. (2001) sugeriram cuidados ao se fazer amostras compostas, quando se têm quantidades diferentes colhidas entre os turnos, dentro de cada dia. 
Neste contexto, 0 objetivo deste trabalho foi avaliar a determinação de óxido de cromo por um novo método para fins de estimativa da digestibilidade in vivo (fluorescência de raios $\mathrm{X}$ com dispersão de energia, realizada no laboratório de Instrumentação Nuclear do Centro de Energia Nuclear na Agricultura, CENA-USP) e os indicadores internos FDN indigestível incubada in vitro por 144 horas (6 dias) e a lignina detergente ácido, comparados à colheita total de fezes, para estimar a digestibilidade da matéria seca (MS), matéria orgânica (MO), fibra em detergente neutro (FDN), fibra em detergente ácido (FDA), proteína bruta (PB) e extrato etéreo (EE), em novilhos Nelore alimentados com três fontes de nitrogênio: 1) farelo de soja em uma dieta deficiente em PDR; 2) uréia; 3) amiréia (fonte de nitrogênio não protéico de suposta liberação gradativa de nitrogênio) sendo as duas ultimas dieta, adequada em PDR, utilizando o bagaço de cana-de-açúcar in natura como única fonte de volumoso ( $20 \%$ da MS).

\subsection{Material e métodos}

\subsubsection{Animais e instalações experimentais}

Foram utilizados seis garrotes mestiços da raça Nelore com cânula no rúmen e duodeno proximal, com peso médio inicial de $420 \mathrm{~kg}$, distribuídos em um quadrado latino $3 \times 3$ duplicado.

$\mathrm{O}$ experimento foi conduzido nas instalações experimentais de bovinos do Departamento de Zootecnia ESALQ-USP. Os animais foram alojados em baias individuais cobertas, do tipo "tie stall" (1×2,2m), providas de bebedouros automáticos e cocho para alimentação. O período experimental foi realizado durante o período de fevereiro a abril de 2001. 


\subsubsection{Tratamentos}

Os animais foram alimentados com dietas contendo bagaço de cana-de-açúcar in natura (BIN) como volumoso (20\%) e $80 \%$ de concentrado (Tabela 29), sendo que os tratamentos experimentais foram feitos pela substituição da fonte de proteína verdadeira (farelo de soja - FS), em uma dieta deficiente em PDR, por uréia ou amiréia (A-150S - fonte de nitrogênio não protéico de suposta liberação gradativa de nitrogênio), sendo as duas fontes utilizadas em uma dieta adequada em PDR.

As fontes de uréia utilizadas foram: a uréia (adubo convencional) e a uréia extrusada, sendo o milho, a fonte de amido utilizada (Amiréia $150 S^{\circledR}$, Pajoara indústria e comércio, Campo Grande, MS).

Os tratamentos (Tabela 29) foram formulados para resultarem em dietas isoprotéicas e isoenergéticas, utilizando o programa do NRC (1996) de bovinos de corte.

Os concentrados foram misturados previamente em um misturador horizontal (marca Lucato, capacidade de $250 \mathrm{~kg}$ ). Na hora do fornecimento da alimentação, o BIN e o concentrado, nas suas respectivas proporções, foram misturados manualmente e fornecidos como ração completa duas vezes ao dia (6 e 18h). 
Tabela 29. Composição em ingredientes e a composição química das dietas (\% da MS).

\begin{tabular}{|c|c|c|c|}
\hline \multirow{2}{*}{ Ingredientes } & \multicolumn{3}{|c|}{ Tratamentos $^{1}$} \\
\hline & FS & Uréia & $A-150 S$ \\
\hline Bagaço in natura (BIN) & 20,5 & 20,5 & 20,5 \\
\hline Milho moído & 27,5 & 33,2 & 30,9 \\
\hline Polpa cítrica & 33,1 & 41,0 & 41,0 \\
\hline Farelo de soja (FS) & 16,5 & - & - \\
\hline Uréia & - & 2,46 & - \\
\hline Amiréia (A-150S) & - & - & 4,78 \\
\hline Mistura mineral $\left.\right|^{2}$ & 1,37 & 1,37 & 1,37 \\
\hline Cloreto de potássio & - & 0,41 & 0,41 \\
\hline Bicarbonato de sódio & 1,09 & 1,09 & 1,09 \\
\hline \multicolumn{4}{|l|}{ Composição química } \\
\hline MS (\% da matéria natural) & 73,4 & 74,3 & 71,4 \\
\hline Proteína bruta & 13,4 & 13,2 & 13,2 \\
\hline Fibra em detergente neutro & 28,5 & 28,5 & 28,3 \\
\hline Fibra em detergente ácido & 23,8 & 24,2 & 24,1 \\
\hline Matéria mineral & 4,3 & 3,8 & 3,8 \\
\hline Extrato etéreo & 3,7 & 4,1 & 3,7 \\
\hline $\mathrm{FDNi}^{3}$ & 17,9 & 18,4 & 18,2 \\
\hline Lignina (LDA) & 4,3 & 4,6 & 4,5 \\
\hline
\end{tabular}

${ }_{1}^{1} \mathrm{FS}=$ farelo de soja; $\mathrm{A}-150 \mathrm{~S}=$ amiréia;

${ }^{2}$ Composição no tratamento F.soja= NÑP=1,74\%; $\mathrm{Ca}=0,012 \% ; \mathrm{P}=4 \% ; \mathrm{S}=2,7 \% ; \mathrm{Cb}=750$ ppm; l=40 ppm; $\mathrm{Mn}=1500$ ppm; Se=10 ppm; $\mathrm{Zn}=2250$ ppm; vit.A=300000 Ul/kg; vit.D3=20000 Ul/kg; Vit.E=3500 Ul/kg;

Rumensin=2\%. Tratamento uréia e amiréia $=N \tilde{N} P=4,35 \% ; \mathrm{Ca}=0,012 \% ; \mathrm{P}=10 \% ; \mathrm{S}=7,1 \% ; \mathrm{Mg}=2,0 \%$;

$\mathrm{Cb}=750$ ppm; I=40 ppm; Mn=1500 ppm; Se=10 ppm; Zn=2250 ppm; vit.A=300000 Ul/kg; vit.D3=20000

$\mathrm{UI} / \mathrm{kg}$; Vit.E=3500 Ul/kg; Rumensin=2\%;

${ }^{3} \mathrm{FDNi}=$ fibra em detergente neutro indigestível, incubada por 144 horas in vitro. 


\subsubsection{Período experimental}

O período experimental teve duração de 84 dias, sendo os primeiros 30 dias destinados ao processo de adaptação dos animais às instalações e às dietas experimentais; e o restante do período, foi segmentado em três sub-períodos de 18 dias, sendo destinado os 14 primeiros dias dos sub-períodos para adaptação dos animais às novas dietas e os quatro últimos dias para colheita de dados e amostras.

\subsubsection{Colheita de dados referentes ao consumo de matéria seca}

Os dados de consumo de MS por animal/dia foram obtidos através da diferença entre a quantidade de MS fornecida e da MS da sobra. As amostras das dietas fornecidas e das sobras do $15^{0}$ ao $18^{0}$ dias foram amostradas uma vez por dia e compostas por animal dentro de cada subperíodo.

As amostras foram conservadas congeladas a $-10^{\circ} \mathrm{C}$ até serem descongeladas e secas em estufas com ventilação forçada $\left(55^{\circ} \mathrm{C}\right)$ por 72 horas e posteriormente, por 12 horas a $105^{\circ} \mathrm{C}$ para determinação de matéria seca, de acordo com Silva (1990).

\subsubsection{Colheita de amostras para determinação da digestibilidade aparente no trato digestivo total}

Foram realizadas colheitas das amostras de fezes, na porção final do reto, nos quatro últimos dias de cada sub-período à cada oito horas, adiantando duas horas por dia, de maneira que se obtivesse uma amostra a cada duas horas no intervalo de 24 horas depois do término dos quatro dias de 
colheita. As amostras foram compostas por animal e período e acondicionadas em sacos plásticos e congeladas $\mathrm{a}-10^{\circ} \mathrm{C}$.

A colheita total de fezes foi realizada nos quatro últimos dias de cada sub-período, sendo estas pesadas, com intervalos de doze horas, para a determinação da quantidade de fezes excretadas em $\mathrm{kg}$ de matéria seca. Foi feito amostragem de $5 \%$ das fezes totais durante os quatro últimos dias de cada sub-período, essas foram compostas por animal e por sub-período. As amostras foram conservadas a $-10^{\circ} \mathrm{C}$ até o término do experimento.

A metodologia utilizada para determinação do cromo foi a de fluorescência de aios $X$, no laboratório de Instrumentação Nuclear do Centro de Energia Nuclear na Agricultura, CENA-USP, descrita por Konrdorfer et al. (2001), utilizando parcelas de $1 \mathrm{~g}$ de fezes foram colocadas em receptáculos especiais (polyethylene X-ray sample cups. Chemplex industries. USA) para determinação através de EDXRF, individualmente, correspondendo a cada animal em cada sub-período experimental. As amostras foram excitadas durante 50 segundos com tubos de raios $X$ com alvo de Mo e filtro de $\mathrm{Ni}$, operando a $10 \mathrm{kV} / 20 \mathrm{~mA}$. Na detecção de raios $X$ característicos, foi utilizado um sistema de alta resolução, empregando um semicondutor de $\mathrm{Si}(\mathrm{Li})$, acoplado a um analisador de pulsos multicanal. Os espectros obtidos foram interpretados pelo aplicativo Analysis of X-Ray Spectra by Interative Least Square Fitting, AXIL.

A digestibilidade (D) aparente no trato digestivo total da MS e demais nutrientes da dieta utilizando os indicadores óxido de cromo, FDNi e LDA foi calculada pela fórmula:

$D=100-\left(\begin{array}{c}100 \times \frac{\% \text { do marcador no alimento }}{\% \text { do marcador nas fezes }} \times \frac{\% \text { do nutriente nas fezes }}{\% \text { do nutriente no alimento }}\end{array}\right)$ 
A digestibilidade (D) aparente no trato digestivo total da MS e demais nutrientes da dieta, utilizando a colheita total de fezes, foi calculada pela fórmula:

$\mathrm{D}=100-\left(\frac{\mathrm{kg} \text { do nutriente consumido }-\mathrm{kg} \text { do nutriente nas fezes }}{\mathrm{kg} \text { do nutriente consumido }}\right)$

\subsubsection{Análise bromatológica das dietas, sobras e fezes}

As amostras do alimento oferecido, sobras e fezes foram secas em estufas com ventilação forçada à temperatura de $55^{\circ} \mathrm{C}$ por 72 horas e moídas em moinhos tipo Wiley (Marconi, Piracicaba, SP) primeiramente em peneira com crivos de $2 \mathrm{~mm}$ e após em peneira com crivos de $1 \mathrm{~mm}$. Posteriormente, essa amostra voltou a estufa por 12 horas a $105^{\circ} \mathrm{C}$ para determinação de matéria seca de acordo com Silva (1990); MM, EE e N de acordo com AOAC (1990); FDN, FDA de acordo com o método de Van Soest et al. (1991), não seqüencial, utilizando amilase e sulfito de sódio nas determinações de FDN; lignina de acordo com Goering \& Van Soest, (1970) e a FDNi segundo Conchran et al. (1986). O EE nas fezes foi determinado com éter de petróleo adicionado de $10 \%$ de ácido acético, para liberar os ácidos graxos (Mattos \& Palmquist, 1974). A MO foi obtida pela subtração da MM da MS.

\subsubsection{Delineamento experimental e análise estatística}

O delineamento estatístico utilizado foi o quadrado latino $3 \times 3$ duplicado com parcelas subdivididas. Os tratamentos da parcela principal foram 
as fontes nitrogenadas, com e sem deficiência em PDR, e os da subparcelas, os indicadores internos (FDNi e LDA) e externo (óxido de cromo). A partir destes resultados, estimou-se a digestibilidade da MS, MO, PB, FDN, FDA e EE. Os resultados foram comparados com os obtidos por meio de colheita total de fezes e analisados pela análise da variância e comparação de médias pelo teste Tukey, por intermédio do procedimento GLM do Statistical Analysis Sistems (SAS, 1988).

Considerou-se 5\% $(\mathrm{P}<0,05)$ como nível de significância e até $10 \%$ como tendência $(P<0,10)$ para a probabilidade do teste $F$ na análise da variância. Para as variáveis que obtiveram respostas significativas, utilizou-se 0 teste de Tukey e o comando LSMEANS/PDIFF para verificar as diferenças entre os tratamentos para as diversas variáveis. As médias das tabelas foram obtidas pelo comando LSMEANS para as parcelas e sub-parcelas.

\subsection{Resultados e discussão}

Os resultados obtidos de digestibilidade dos nutrientes estimada pela colheita total de fezes ou por intermédio dos indicadores interno (FDNi e lignina) e externo (Cromo) nos respectivos tratamentos estão apresentados nas Tabelas 30, 31 e 32 .

Observou-se um efeito significativo $(P<0,05)$ no quadro da análise da variância para todas as frações (MS, MO, PB, FDN, FDA e EE) entre os indicadores. 
Tabela 30. Digestibilidade da matéria seca e matéria orgânica determinadas utilizando indicadores e colheita total de fezes em novilhos Nelore suplementados com fontes nitrogenadas.

\begin{tabular}{|c|c|c|c|c|c|}
\hline \multirow{2}{*}{ Indicadores } & \multicolumn{3}{|c|}{ Tratamentos $^{2}$} & \multirow{2}{*}{$\mathrm{EPM}^{3}$} & \multirow{2}{*}{ Subparcela ${ }^{4}$} \\
\hline & FS & Uréia & A-150S & & \\
\hline \multicolumn{6}{|c|}{ Matéria seca } \\
\hline Colheita total de fezes & $70,1^{a}$ & $71,8^{a}$ & $73,4^{a}$ & 1,47 & $71,8^{a}$ \\
\hline Óxido de cromo & $67,1^{\mathrm{a}}$ & $76,1^{\mathrm{a}}$ & $76,3^{a}$ & 1,47 & $73,2^{a}$ \\
\hline $\mathrm{FDNi}^{1}$ & $55,8^{b}$ & $53,9^{\mathrm{C}}$ & $54,6^{\mathrm{c}}$ & 1,47 & $54,8^{c}$ \\
\hline Lignina & $67,1^{\mathrm{a}}$ & $62,0^{b}$ & $63,3^{b}$ & 1,47 & $64,1^{\mathrm{b}}$ \\
\hline Parcelas ${ }^{5}$ & 65,0 & 65,9 & 66,9 & 1,38 & \\
\hline \multicolumn{6}{|c|}{ Matéria orgânica } \\
\hline Colheita total de fezes & $73,4^{a}$ & $74,6^{a}$ & $76,2^{a}$ & 1,29 & $74,7^{\mathrm{a}}$ \\
\hline Óxido de cromo & $70,8^{a}$ & $78,4^{a}$ & $78,8^{a}$ & 1,29 & $76,0^{\mathrm{a}}$ \\
\hline FDNi & $60,7^{b}$ & $58,6^{c}$ & $59,4^{\mathrm{C}}$ & 1,29 & $59,5^{c}$ \\
\hline Lignina & $70,7^{a}$ & $65,7^{b}$ & $68,4^{b}$ & 1,29 & $68,3^{b}$ \\
\hline Parcelas ${ }^{5}$ & 68,9 & 69,3 & 70,7 & 1,22 & \\
\hline
\end{tabular}

a,b,c=Letras diferentes nas colunas referem-se as médias que diferem entre si pelo teste Tukey $(\mathrm{P}<0,05)$; as médias foram ajustadas pelos quadrados mínimos (LSMEANS);

${ }_{1}^{1} \mathrm{FDNi}=$ fibra em detergente neutro indigestível, incubada por 144 horas in vitro;

${ }^{2} \mathrm{FS}=$ farelo de soja; $\mathrm{A}-150 \mathrm{~S}=$ amiréia;

${ }^{3}$ EPM=erro padrão da média;

${ }^{4}$ Média das subparcelas (marcadores);

${ }^{5}$ Média das parcelas (tratamentos).

Óxido de cromo (analisado por fluorescência de raios- $X$ ) não diferiu $(P>0,05)$ da colheita total de fezes, nos coeficientes de digestibilidade aparente da MS, MO, PB, FDN, FDA e EE independente do tratamento (Tabelas 30, 31 e 32). O óxido de cromo foi o único indicador que apresentou efeito $(P<0,05)$ de tratamento nas frações FDN e FDA (Tabela 31), embora não diferiu $(P>0,05)$ da colheita total de fezes entre tratamentos. A redução na digestibilidade da fibra no tratamento farelo de soja era esperado em virtude da 
deficiência de proteína degradável no rúmen (PDR) (Russell et al, 1992 e Tedeschi et al, 2000), mas não foi confirmado pela colheita total de fezes.

Os resultados observados podem ser um indicativo de que 0 óxido de cromo parece mover-se com os constituintes fibrosos, devido a uma provável fixação entre as fendas da fibra como observado por King \& Moore (1957). Neste mesmo sentido, Lameourne (1957) observou uma excreção mais lenta de óxido de cromo em ovelhas alimentadas com forragem de baixa qualidade; o mesmo foi sugerido por Lima et al. (1980). Resultados opostos a estes foram observados por Hardison et al. (1959).

A fibra em detergente neutro indigestível (FDNi) incubada por 144 horas (6 dias) in vitro não diferiu apenas na estimativa da digestibilidade da fração FDN em relação a colheita total de fezes; também subestimou $(P<0,05)$ a digestibilidade das demais frações (MS, MO, PB, FDA e EE) avaliadas, independente do tratamento ou média dos indicadores (subparcelas) estando de acordo com Ítavo et al. (2001), quando alimentaram animais Nelore com diferentes teores de concentrados (20, 40, 60 e 80\%). Esses autores concluíram que a FDNi subestimou a digestibilidade aparente dos nutrientes.

Paziani et al. (2000) observaram dados de digestibilidade calculados com $\mathrm{Cr}_{2} \mathrm{O}_{3}$ superiores $(\mathrm{P}<0,05)$ do que os com FDN indigestível, mas não realizaram colheita total de fezes. Estes dados são similares aos observados neste experimento.

Ezequiel et al. (1999), utilizando a FDNi (incubada por $120 \mathrm{~h}$ in vitro) como indicador de digestibilidade em novilhos suplementados com farelo de soja (que possui proteína de média degradabilidade); amiréia (fonte de NNP) e farinha de subprodutos de abatedouro avícola (fonte de proteína de baixa degradabilidade), não observaram efeito de tratamento na digestibilidade da MS, PB e FDN; embora não avaliaram a colheita total de fezes. Esses resultados são similares aos observados nas Tabelas 30, 31 e 32; entretanto, quando se utilizou a FDNi, a digestibilidade da MS e PB em relação a colheita total de fezes foi subestimada no atual experimento (Tabelas 30 e 32). 
Tabela 31. Digestibilidade da fibra em detergente neutro e fibra em detergente ácido determinadas utilizando indicadores e colheita total de fezes em novilhos Nelore suplementados com fontes nitrogenadas.

\begin{tabular}{|c|c|c|c|c|c|}
\hline \multirow{2}{*}{ Indicadores } & \multicolumn{3}{|c|}{ Tratamentos $^{2}$} & \multirow{2}{*}{$\mathrm{EPM}^{3}$} & \multirow{2}{*}{ Subparcela } \\
\hline & FS & Uréia & A-150S & & \\
\hline \multicolumn{6}{|c|}{ Fibra em detergente neutro } \\
\hline Colheita total de fezes & $55,3^{\mathrm{ab}}$ & $61,2^{\mathrm{a}}$ & $62,2^{a}$ & 1,82 & $59,6^{a}$ \\
\hline Óxido de cromo & $51,6^{\mathrm{Bb}}$ & $67,2^{\mathrm{Aa}}$ & $66,5^{\mathrm{Aa}}$ & 1,82 & $61,8^{a}$ \\
\hline $\mathrm{FDNi}^{1}$ & $61,1^{a}$ & $58,9^{a}$ & $59,4^{a}$ & 1,82 & $59,8^{a}$ \\
\hline Lignina & $51,3^{b}$ & $47,5^{\mathrm{b}}$ & $50,8^{b}$ & 1,82 & $49,8^{b}$ \\
\hline Parcelas $^{5}$ & $54,8^{\mathrm{B}}$ & $58,7^{A}$ & $59,7^{\mathrm{A}}$ & 1,71 & \\
\hline \multicolumn{6}{|c|}{ Fibra em detergente ácido } \\
\hline Colheita total de fezes & $60,9^{a}$ & $66,2^{\mathrm{a}}$ & $67,4^{a}$ & 1,60 & $64,8^{\mathrm{a}}$ \\
\hline Óxido de cromo & $57,6^{\mathrm{Ba}}$ & $71,4^{\mathrm{Aa}}$ & $71,0^{\mathrm{Aa}}$ & 1,60 & $66,7^{\mathrm{a}}$ \\
\hline $\mathrm{FDNi}$ & $42,8^{b}$ & $44,8^{\mathrm{C}}$ & $44,8^{\mathrm{C}}$ & 1,60 & $44,1^{\mathrm{c}}$ \\
\hline Lignina & $57,2^{\mathrm{a}}$ & $54,3^{b}$ & $57,1^{b}$ & 1,60 & $56,2^{b}$ \\
\hline Parcelas ${ }^{5}$ & $54,6^{\mathrm{B}}$ & $59,2^{A}$ & $60,1^{\mathrm{A}}$ & 1,50 & \\
\hline
\end{tabular}

a,b,c=Letras diferentes nas colunas referem-se as médias que diferem entre si pelo teste Tukey $(P<0,05) ;{ }^{A, B}=$ Letras diferentes nas linhas referem-se as médias que diferem entre si pelo teste Tukey $(P<0,05)$; as médias foram ajustadas pelos quadrados mínimos (LSMEANS);

${ }^{1} \mathrm{FDNi}=$ fibra em detergente neutro indigestível, incubada por 144 horas in vitro;

${ }^{2} \mathrm{FS}=$ farelo de soja; $\mathrm{A}-150 \mathrm{~S}=$ amiréia;

${ }^{3} \mathrm{EPM}=$ erro padrão da média;

${ }^{4}$ Média das subparcelas (marcadores);

${ }^{5}$ Média das parcelas (tratamentos).

Discordando dos dados observados por Berchielli et al. (2000) na estimativa da digestibilidade e Detmann et al. (2001) na estimativa de consumo de animais sob pastejo, os dados do atual experimento demonstram que a FDNi não deve ser utilizada neste tipo de dieta (alta proporção de grãos) como 
indicador. Conchran et al. (1986) observaram variações nas estimativas da digestibilidade em diferentes dietas utilizando a FDNi.

Tabela 32. Digestibilidade da proteína bruta e extrato etéreo determinadas utilizando indicadores e colheita total de fezes em novilhos Nelore suplementados com fontes nitrogenadas.

\begin{tabular}{|c|c|c|c|c|c|}
\hline \multirow{2}{*}{ Indicadores } & \multicolumn{3}{|c|}{ Tratamentos $^{2}$} & \multirow{2}{*}{$\mathrm{EPM}^{3}$} & \multirow{2}{*}{ Subparcela ${ }^{4}$} \\
\hline & FS & Uréia & $A-150 S$ & & \\
\hline \multicolumn{6}{|c|}{ Proteína bruta } \\
\hline Colheita total de fezes & $78,7^{\mathrm{a}}$ & $81,3^{\mathrm{a}}$ & $81,7^{a}$ & 1,16 & $80,6^{a}$ \\
\hline Óxido de cromo & $76,8^{a}$ & $84,1^{\mathrm{a}}$ & $83,7^{a}$ & 1,16 & $81,5^{a}$ \\
\hline $\mathrm{FDNi}^{1}$ & $68,0^{b}$ & $69,3^{c}$ & $68,5^{c}$ & 1,16 & $68,6^{c}$ \\
\hline Lignina & $76,3^{\mathrm{a}}$ & $74,7^{b}$ & $75,5^{b}$ & 1,16 & $75,5^{b}$ \\
\hline Parcelas $^{5}$ & 74,9 & 77,4 & 77,3 & 1,09 & \\
\hline \multicolumn{6}{|c|}{ Extrato etéreo } \\
\hline Colheita total de fezes & $69,2^{a}$ & $69,1^{\mathrm{a}}$ & $73,3^{a}$ & 2,05 & $70,5^{\mathrm{a}}$ \\
\hline Óxido de cromo & $66,1^{a}$ & $73,8^{a}$ & $76,1^{\mathrm{a}}$ & 2,05 & $72,0^{\mathrm{a}}$ \\
\hline FDNi & $53,2^{b}$ & $48,9^{c}$ & $54,7^{\mathrm{c}}$ & 2,05 & $52,3^{c}$ \\
\hline Lignina & $65,5^{a}$ & $58,3^{b}$ & $64,4^{b}$ & 2,05 & $62,7^{b}$ \\
\hline Parcelas $^{5}$ & 63,5 & 62,5 & 67,1 & 1,93 & \\
\hline
\end{tabular}

a,b,c=Letras diferentes nas colunas referem-se as médias que diferem entre si pelo teste Tukey $(\mathrm{P}<0,05)$; as médias foram ajustadas pelos quadrados mínimos (LSMEANS);

${ }_{1} \mathrm{FDNi}=$ fibra em detergente neutro indigestível, incubada por 144 horas in vitro;

${ }^{2} \mathrm{FS}=$ farelo de soja; $\mathrm{A}-150 \mathrm{~S}=$ amiréia;

${ }^{3} \mathrm{EPM}=$ erro padrão da média;

${ }_{5}^{4}$ Média das subparcelas (marcadores);

${ }^{5}$ Média das parcelas (tratamentos).

Confirmando os dados do atual experimento, Fregadolli et al. (2000) utilizando a fibra em detergente neutro indigestível (incubação ruminal por 192 horas) como indicador, observaram uma subestimação na 
digestibilidade ruminal e total da MS e MO, não obtendo desta maneira resultados confiáveis, sugerindo que o óxido de cromo foi o melhor indicador avaliado, pois apresenta uma menor variação (CV). Ítavo et al. $(2000,2002)$ também não obtiveram bons resultados com a FDN indigestível (incubação ruminal de 144 horas), Entretanto, Zeoula et al. (2001) observaram que a FDNi (incubada no rúmen por 8 horas) verificaram valores semelhantes aos da colheita total de fezes, apresentando uma recuperação próxima dos $100 \%$ $(P>0,05)$, sendo adequada para estimar a digestibilidade da MS em ovinos castrados.

É importante notar que os autores mencionados acima utilizaram o procedimento in situ. Neste experimento, utilizou-se o procedimento in vitro, uma vez que, Piaggio et al. (1991) atribuíram que as variações existentes na recuperação de indicadores indigestíveis estão associadas æ̀s perdas de partículas ocorridas pelos poros dos sacos de náilon. Contrariando esta observação, Freitas et al. (2002) verificaram que as estimativas de produção fecal obtidas com o uso da FDNi incubada in vitro e FDNi incubada in situ foram sub e superestimadas, respectivamente. Os autores recomendaram a FDA in vitro. Outro problema apontado por Lippke et al. (1986) foi que, boa parte da variabilidade dos resultados obtidos com indicadores internos indigestíveis pode ser atribuída àfalta de padronização no método de determinação.

A lignina em detergente ácido (LDA) apresentou estimativas da digestibilidade de todas as frações (MS, MO, PB, FDN, FDA e EE) avaliadas similarmente $(P>0,05)$ aos da colheita total de fezes no tratamento FS (deficiente em PDR), mas, subestimou a digestibilidade de todas as frações (MS, MO, PB, FDN, FDA e EE) nos tratamentos uréia e amiréia (PDR ajustada) em relação a colheita total de fezes. Estes dados sugerem que dietas ajustadas em PDR (uréia e amiréia), onde se espera ocorrer uma maior digestibilidade da fração fibra (FDN e FDA), poderia estar contribuindo para a redução da recuperação da LDA nas fezes, fato este comprovado, quando se utilizou óxido 
de cromo como marcador (Tabela 31), ou numericamente maior através da colheita total de fezes.

Os resultados obtidos no atual experimento estão de acordo com Muntifering (1982), Fahey \& Jung (1983) e Van Soest (1994), os quais reportaram recuperações positivas e incompletas da lignina, sugerindo que 0 uso de lignina como indicador deve ser utilizado com cautela, sendo viável sua utilização quando se tem informação da sua recuperação (Merchen, 1988), o que fica evidente neste experimento.

As alterações na recuperação da lignina também pode ter efeito de raça segundo Lançanova et al. (2000), os quais observaram uma recuperação do indicador LDA de apenas $83 \%$ para os animais da raça Nelore, ficando os valores de recuperação do indicador para as demais raças avaliadas (Zebuinas e Taurinas) próximos a $98 \%$. Os autores concluíram que a lignina em detergente ácido foi eficiente na estimativa da digestibilidade do EE, PB e da fibra.

Silva et al. (2002), utilizando a LDA como indicador de digestibilidade em novilhos suplementados com farelo de soja (que possui proteína de média degradabilidade); amiréia (fonte de NNP) e farinha de subprodutos de abatedouro avícola (fonte de proteína de baixa degradabilidade), não observaram alterações na digestibilidade da $\mathrm{MS}, \mathrm{MO}$, PB, FDN e FDA entre os tratamentos; embora, não realizaram a colheita total de fezes. Esses resultados foram similares aos observados no atual experimento no tocante ao efeito de tratamento, mas, a utilização de LDA levou a uma subestimação dos coeficientes de digestibilidade nos tratamentos com NNP (uréia e amiréia) em relação àcolheita total de fezes no atual experimento (Tabelas 30, 31 e 32).

Mendes et al. (2001) observaram que a lignina subestimou significativamente $(\mathrm{P}<0,05)$ os coeficientes de digestibilidade total, quando comparada a digestibilidade total estimada por FDA e lignina indigestível, as quais não diferiram entre si. Resultados similares foram verificados por 
Thonney et al. (1979) e Valadares Filho et al. (1985), os quais observaram uma estimativa da digestibilidade total através do óxido crômico ou pelo método de colheita total em média $24 \%$ superior aos observados pela lignina. Estes dados estão próximos dos observados no atual experimento, onde se observou um coeficiente de digestibilidade da MS por colheita total de fezes e pelo óxido de cromo de 15 e $20 \%$ superior aos de LDA, respectivamente, nos tratamentos com nitrogênio não protéico (uréia e amiréia), mas, discordando dos observados no tratamento FS.

Segundo Fahey \& Jung (1983) as prováveis razões para a baixa recuperação da lignina são: digestão verdadeira; digestão aparente obtida pela formação de complexo lignina-carboidratos solúveis que passam pelo rúmen e, provavelmente, pelo intestino como polímeros e não são recuperados no resíduo de fibra das fezes; destruição parcial da lignina fecal pelos reagentes utilizados nos métodos analíticos e diferenças químicas e/ou físicas entre alimentos e fezes nos materiais naturais empiricamente definidos como lignina.

\subsection{Conclusões}

O indicador externo óxido de cromo analisado por fluorescência de raios- $X$ apresentou resultados semelhantes, na estimativa da digestibilidade, aos da colheita total de fezes, demonstrando ser promissora esta técnica de análise do cromo, bem como a metodologia (dias e horários) utilizada para colheita das amostras.

O indicador interno FDNi incubada por 144 horas in vitro não representou a fração indigestível da dieta (alta proporção de concentrado), necessitando de mais informações de sua recuperação na dieta em questão para viabilizar o seu uso.

O sucesso do uso lignina como indicador interno de digestibilidade parece estar relacionado com a dieta, ou seja, em dieta com PDR adequada 
(via NNP) subestima a digestibilidade, mas em dietas com deficiência de PDR e fonte de proteína verdadeira (farelo de soja), apresenta boas estimativas. 


\section{CONCLUSÕES GERAIS}

Quando as exigências em PDR são atendidas (via uréia ou amiréia), em dietas com alta proporção de concentrado, melhorou o consumo dos nutrientes e o desempenho de bovinos na fase de crescimento, quando comparado a uma fonte de proteína verdadeira (farelo de soja) sem atender as exigências em PDR.

A substituição de farelo de soja por fontes de nitrogênio não protéico (uréia ou amiréia), em dietas contendo 45\% de BTPV e 5\% de BIN como volumoso na MS, reduz o desempenho de bovinos na fase de terminação.

A suplementação com uréia (dieta adequada em PDR) promoveu uma maior retenção de nitrogênio ( $\mathrm{g} / \mathrm{d}$ e $\%$ do $\mathrm{N}$ consumido) e valor biológico da proteína ( $\mathrm{N}$ retido, \% do digerido) em bovinos de corte, em relação ao uso de uma fonte de proteína verdadeira (farelo de soja) sem atender as exigências em PDR ou atendê-las via amiréia.

A amiréia promove resultados similares a uréia convencional no consumo dos nutrientes, digestibilidade, parâmetros ruminais e sanguíneos e no desempenho de bovinos de corte confinados.

O nitrogênio proveniente da amiréia é praticamente todo prontamente solúvel em água (fração "a") e também a amiréia não promove "proteção de cocho" do nitrogênio. Esse $\mathrm{N}$ solúvel, com base na literatura, poderá provocar intoxicações aos animais, tanto por consumo de altas quantidades ou por tomar água da chuva represada no cocho que contém amiréia pura ou no suplemento. 
O indicador externo óxido de cromo analisado por fluorescência de raios-X proporcionou resultados similares, na estimativa da digestibilidade, aos da colheita total de fezes, demonstrando ser promissora esta técnica de análise do cromo, bem como a metodologia (dias e horários) utilizada para colheita das amostras.

Os indicadores internos FDNi incubada por 144 horas in vitro e a lignina (LDA), necessitam de mais informações de suas recuperações em dietas com alto teor de concentrado, fontes nitrogenadas, bem como a qualidade e a quantidade de PDR, para viabilizar as suas utilizações.

O bagaço de cana-de-açúcar in natura promove boa estabilidade ruminal quando utilizado como única fonte de volumoso (20\% da MS) em dietas com alto teor de concentrado ( $80 \%$ da MS). 


\section{REFERÊNCIAS BIBLIOGRÁFICAS}

AGRICULTURAL RESEARCH COUNCIL. The nutrient requirements of ruminant livestock. Famham Royal: CAB International. 1994. 351p.

ALLEN, M.S. Fiber requirements for dairy cattle? How low can go? In: CALIFORNIA NUTRITION CONFERENCE, Davis, 1996. Proceedings. Davis: University of California, 1996. p.12-18.

ALLEN, M.S. Relationship between fermentation and acid production in the rumen and requirement for physically effective fiber. Journal of Dairy Science, v.80, p.1447-1462, 1997.

ARCHIBEQUE, S.L.; BURNS, J.C.; HUNTINGTON, G.B. Urea flux in beef steers: Effects of forage species and nitrogen fertilization. Journal of Animal Science, v.79, p.1937-1943, 2001.

ARMENTANO, L.E.; PEREIRA, M.N. Measuring the effectiveness of fiber by animal response trials. Journal of Dairy Science, v.80, p.1416-1425, 1997.

ASSOCIATION OF OFFICIAL ANALYTICAL CHEMISTS. Official Methods of Analysis. 15.ed. Arlington: AOAC, 1990. v.1, 1117p. 
BARR, G.W.; BARTLEY, E.E.; MEYER, R.M. Feed processing. 8. Estimating microbial protein in rumen fluid with precipitating agents or in incubated mixtures of uncooked grain plus urea or starea with differential centrifugation. Journal of Dairy Science, v.58, n.9, p.1308-1313, 1975.

BARTLEY, E.E.; DAVIDOVICH, A.D.; BARR, G.W.; GRIFFER, G.W. Ammonia toxicity in cattle. I. Rumen and blood changes associated with and treatment methods. Journal of Animal Science, v.43, n.4, p.835-841, 1976.

BARTLEY, E.E.; DEYOE, C.W. Starea as a protein replacer for ruminants review of 10 years of research. Feedstuffs, v.47, n.30, p.42-44, 1975.

BARTLEY, E.E.; DEYOE, C.W.; BEHNKE, K.C.; GRIFFEL, G.W.; MEYER, R.M. Toxicity of starea or cooked grain-urea products. Journal of Animal Science, v.37, n.1, p.336-337, 1973.

BERCHIELLI, T.T.; ANDRADE, P.; FURLAN, C.L. Avaliação de indicadores internos em ensaios de digestibilidade. Revista Brasileira de Zootecnia, v.29, n.3, p.830-833, 2000.

BLAXTER, K.L. The energy metabolism of ruminants. London, Hutchinson, 1962. 329p.

BLOCK, H.C.; McKINNON, J.J.; MUSTAFA, A.F.; CHRISTENSEN, D.A. Evaluation of the 1996 NRC beef model under western Canadian environmental conditions. Journal of Animal Science, v.79, p.267-275, 2001. 
BOHNERT, D.W.; SCHAUER, C.S.; DELCURTO, T. Influence of rumen protein degradability and supplementation frequency on performance and nitrogen use in ruminants consuming low-quality forage: Cow performance and efficiency of nitrogen use in weathers. Journal of Animal Science, v.80, n.6, p.1629-1637, 2002.

BRODERICK, G.A.; CLAYTON, M.K. A statistical of animal and nutrition factors influencing concentrations of milk urea nitrogen. Journal of Dairy Science, v.80, p.2964-2971, 1997.

BULLE, M.L.M. Desempenho, composição corporal e exigências líquidas de energia e proteína de tourinhos de dois tipos genéticos alimentados com dietas de alto teor de concentrado. Piracicaba, 2000. 50p. Dissertação (Mestrado) - Escola Superior de Agricultura "Luiz de Queiroz", Universidade de São Paulo.

BULLE, M.L.M.; RIBEIRO, F.G.; LEME, P.R.; TITTO, E.A.L.; LANNA, D.P.D. Desempenho de tourinhos cruzados em dietas de alto teor de concentrado em bagaço de cana-de-açúcar como único volumoso. Revista Brasileira de Zootecnia, v.31, n.1, p.444-450, 2002a.

BULLE, M.L.M.; RIBEIRO, F.G.; LEME, P.R.; TITTO, E.A.L.; LANNA, D.P.D. Exigências líquidas de energia e proteína de tourinhos de dois grupos genéticos alimentados com dietas de alto teor de concentrado. Revista Brasileira de Zootecnia, v.31, n.1, p.436-443, 2002b.

BUNTING, L.D.; BOLING, J.A.; MACKOWN, C.T.; MUNTIFERING, R.B. Effect of dietary protein level on $\mathrm{N}$ metabolism in lambs: Studies using ${ }^{15} \mathrm{~N}$. Journal of Animal Science, v.64, p.855-867, 1987. 
BURGI, R. Produção do bagaço de bagaço de cana-de-açúcar (Saccharum sp.

L) auto-hidrolizado e avaliação do seu valor nutritivo para ruminantes. Piracicaba, 1985. 61p. Dissertação (Mestrado) - Escola Superior de Agricultura "Luiz de Queiroz", Universidade de São Paulo.

CAIELLI, E.D.; BRAUN, G.; POSSENTI, R.A. Bagaço de cana tratado por explosão à vapor em rações de bovinos em confinamento. Boletim da Industria animal, v.54, n.2, p.33-38, 1997.

CARMO, C.A. Substituição do farelo de soja por uréia ou amiréia em dietas para vacas leiteiras. Piracicaba, 2001. 74p. Dissertação (Mestrado) - Escola Superior de Agricultura "Luiz de Queiroz", Universidade de São Paulo.

CARMO, F.R.G.; EZEQUIEL, J.M.B.; GALATI, R.L.; CALDEIRA, G.F.; FEITOSA, J.V.; MENDES, A.R.; FERREIRA, R.N. Degradabilidade ruminal "in situ" da matéria seca e proteína bruta da amiréia contendo $25 \%$ de uréia e com diferentes granulometrias. In: CONGRESSO DE INICIAÇÃO CIENTÍFICA DA UNESP, 11., Botucatu, 1999. Anais. Botucatu:UNESP, 1999. p.254.

CASTRO, F.B. Avaliação do processo de digestão do bagaço de cana-deaçúcar (Saccharum sp. L) auto-hidrolizado em bovinos. Piracicaba, 1989. 123p. Dissertação (Mestrado) - Escola Superior de Agricultura "Luiz de Queiroz", Universidade de São Paulo.

CHALUPA, W. Problems in feed urea to ruminants. Journal of Animal Science, v.27, p.207-219, 1968.

CHANEY, A.L.; MARBACH, E.P. Modified reagents for determination of urea and ammonia. Clinical Chemistry, v.8, p.130-146, 1962. 
CHEN, X.B.; GOMES, M.J. Estimation of microbial protein supply to sheep and cattle based on urinary excretion of purine derivatives. An overview of technical details. Rowett Researsh Institute, Aberdeen, United Kingdom. International Feed Resources Unit, Occasional Publication. 1992. 21p.

COCHRAN, R.C.; ADANS, D.C.; WALLACE, J.D. GALYEAN, M.L. Predicting digestibility of different diets with internal markers: evaluation of four potential markers. Journal of Animal Science, v.63, n.5, p.1476-1483, 1986.

COOPER, R.J.; MILTON, C.T.; KLOPFENSTEIN, T.J.; JORDON, D.J. Effect of corn processing on degradable intake protein requirement of finishing cattle. Journal of Animal Science, v.80, p.242-247, 2002.

COSTA, L.R.O. Suplementação de uréia em dietas de bagaço de cana (Saccharum sp. L) auto-hidrolizado para ruminantes. Piracicaba, 1987. 111p. Dissertação (Mestrado) - Escola Superior de Agricultura "Luiz de Queiroz", Universidade de São Paulo.

DaSILVA, S.C. Efeito de bicarbonato de sódio e/ou lasalocida sobre os parâmetros ruminais de bovinos alimentados com bagaço de cana tratado à pressão e vapor. Piracicaba, 1990. 130p. Dissertação (Mestrado) - Escola Superior de Agricultura "Luiz de Queiroz", Universidade de São Paulo.

DETMANN, E.; PAULINO, M.F.; ZERVOUDAKIS, J.T.; VALADARES FILHO, S.C.; EUCLYDES, R.F.; LANA, R.P.; QUEIROZ, D.S. Cromo e indicadores internos na determinação do consumo de novilhos mestiços suplementados, a pasto. Revista Brasileira de Zootecnia, v.30, n.5, p.1600-1609, 2001. 
DEVANT, M.; FERRET, A.; CALSAMIGLIA, S.; CASALS, R.; GASA, J. Effect of nitrogen source in high-concentrate, bw, protein beef cattle diets on microbial fermentation studied in vivo and in vitro. Journal of Animal Science, v.79, p.1944-1953, 2001.

DEVANT, M.; FERRET, A.; GASA, J.; CALSAMIGLIA, S.; RASALS, R. Effects of protein concentration and degradability on performance, ruminal fermentation, and nitrogen metabolism in rapidly growing heifers fed highconcentrate diets from 100 to $230 \mathrm{~kg}$ body weight. Journal of Animal Science, v.78, p.1667-1676, 2000.

DEYOE, C.W.; BARTLEY, E.E.; PFOST, H.B.; BOREN, F.W.; PERRY, H.B.; ANSTAETT, F.R.; HELMER, L.; STILES, D. An improved urea product for ruminants. Journal of Animal Science, v.27, p.1163, 1968.

EASTRIDGE, L.M. Fibra para vacas leiteiras. In: SIMPÓSIO SOBRE PRODUÇÃO ANIMAL, 9., Piracicaba, 1997. Anais. Piracicaba: FEALQ, 1997. p.33-50.

EDWARDS, J.S.; BARTLEY, E.E.; BECHTLE, R.M. Effects of starea in rations containing 12 percent to 27 percent crude protein on microbial proteinproduction invitro. Journal of Dairy Science, v.60, p.68-69, 1977. Supplement, 1.

EDWARDS, J.S.; BARTLEY, E.E. Soybean-meal or starea for microbial proteinsynthesis or milk-production with rations above 13-percent natural protein. Journal of Dairy Science, v.62, n.5, p.732-739, 1979.

ERDMAN, R.A. Dietary buffering requirements of the lactating dairy cows: A review. Journal of Dairy Science, v.71, n.12, p.3246-3266, 1988. 
EZEQUIEL, J.M.B.; CARMO, F.R.G.; GALATI, R.L.; CALDEIRA, G.F.; FEITOSA, J.V.; MENDES, A.R.; FERREIRA, R.N. Degradabilidade ruminal "in situ" da matéria seca e proteína bruta da amiréia nas formas moídas e peletizada contendo diferentes níveis de uréia. (Compact disc). In: REUNIÓN LATINOAMERICAN DE PRODUCCIÓN ANIMAL, 16., CONGRÉSO URUGUAYO DE PRODUCCIÓN ANIMAL, 3., Mar del Plata. 2000.

EZEQUIEL, J.M.B.; MATARAZZO, S.V.; SALMAN, A.K.D.; MARTINS JÚNIOR, A.P.; SOARES, W.V.B.; SEIXAS, J.R.C. Digestibilidade aparente da energia e da fibra de dietas para ovinos contendo uréia, amiréia ou farelo de algodão. Revista Brasileira de Zootecnia, v.30, n.1, p.231-235, 2001 a.

EZEQUIEL, J.M.B.; MENDES, A.R.; SILVA, L.D.F.; AZEVEDO, P.S.; MIZUBUTI, I.Y; BARBOSA, J.C.; SEIXAS, J.R.C. Estimativa da digestibilidade através da FDN indigestível de rações contendo dois níveis de casca de soja e diferentes fontes protéicas em novilhos mestiços. (Compact disc). In: REUNIÃO ANUAL DA SOCIEDADE BRASILEIRA, Porto Alegre, 1999. Anais. Porto Alegre: Sociedade Brasileira de Zootecnia, 1999.

EZEQUIEL, J.M.B.; SOARES, W.V.B.; SEIXAS, J.R.C. Digestibilidade in vitro da matéria seca, nitrogênio e fibra em detergente ácido de dietas completas contendo farelo de algodão, uréia ou amiréia. Revista Brasileira de Zootecnia, v.30, n.1, p.236-241, 2001b.

FAHEY, G.C.; JUNG, H.G. Lignin as a marker in digestion studies - a review. Journal of Animal Science, v.75, n.1, p.220-225, 1983. 
FEITOSA, J.V.; GALATI, R.L.; CARMO, F.R.G.; EZEQUIEL, J.M.B.; MALHEIROS, E.B.; CALDEIRA, G.F.; FERREIRA, R.N. Modelos de degradabilidade ruminal in situ da matéria seca e proteína bruta em dietas contendo amiréias com diferentes granulometrias e níveis de uréia. (Compact disc). In: REUNIÓN LATINOAMERICAN DE PRODUCCIÓN ANIMAL, 16; CONGRÉSO URUGUAYO DE PRODUCCIÓN ANIMAL, 3., Mar del Plata, 2000.

FENTON, T.W.; FENTON, E. An improved procedure for determination of chromic oxide in food and feces. Canadian Journal Animal Science, v.59, p.631-634, 1979.

FERNANDES, R.H.R. Substituição parcial do farelo de soja por uréia ou amiréia em dietas para cabras em lactação. Piracicaba, 2002. 72p. Dissertação (Mestrado) - Escola Superior de Agricultura "Luiz de Queiroz", Universidade de São Paulo.

FERNANDES, R.H.R.; SUSIN,I.; PIRES, A.V.; ROCHA, M.H.M.; CARMO, C.A.; MENDES, C.Q. Fontes de nitrogênio na alimentação de cabras leiteiras lactantes. (Compact disc). In: REUNIÃO ANUAL DA SOCIEDADE BRASILEIRA, Piracicaba, 2001. Anais. Piracicaba: Sociedade Brasileira de Zootecnia, 2001.

FERRELL, C.L.; FREETLY, H.C.; GOETSCH, A.L.; KREIKEMEIER, K.K. The effect of dietary nitrogen and protein on feed intake, nutrient digestibility, and nitrogen flux across the portal-drained viscera and liver of sheep consuming high-concentrate diet ad libitum. Journal of Animal Science, v.79, p.13221328, 2001. 
FORERO, O.; OWENS, F.N.; LUSBY, K.S. Evaluation of slow-release urea for winter supplementation of lactating range cows. Journal of Animal Science, v.50, p.532-538, 1980.

FOX, D.G.; SNIFFEN, C.J.; O'COMMOR, J.D.; RUSSELL, J.B.; VAN SOEST, P.J. A net-carbohydrate and protein system for evaluating cattle diets: III. Cattle requirements and diet adequacy. Journal of Animal Science, v.70, p.3578-3596, 1992.

FOX, D.G.; TYLUTKI, T.P.; VAN AMBURGH, ME.; CHASE, L.E.; PELL, A.N.; OVERTON, T.R.; TEDESCHI, L.O; RASMUSSEN, C.N.; DURBAL, V.M. The net carbohydrate and protein system for evaluating herd nutrition and nutrient excretion. Ithaca NY: Cornell University. 2000. 235p.

FREGADOLLI, F.L.; ZEOULA, L.M.; KASSIES, M.; CALDAS NETO, S.F.; PRADO I.N.; BRANCO, A.F.; DALPONTE, A.O. Avaliação de indicadores no estudo da digestibilidade dos alimentos. (Compact disc). In: REUNIÃO ANUAL DA SOCIEDADE BRASILEIRA DE ZOOTECNIA, 37., Viçosa, MG, 2000. Anais. Viçosa, MG:SBZ, 2000.

FREITAS, D.; BERCHIELLI, T.T.; SILVEIRA, R.N.; SOARES, J.P.G.; FERNANDES, J.J.R.; PIRES, A.V. Produção fecal e fluxo duodenal de matéria seca e matéria orgânica estimados por meio de indicadores. Revista Brasileira de Zootecnia, v.31, n.3, p.1521-1530, 2002.

FU, C.J.; FELTON, E.E.D.; LEHMKUHLER, J.W.; KERLEY, M.S. Ruminal peptide concentration required to optimize microbial growth and efficiency. Journal of Animal Science, v.79, p.1305-1312, 2001. 
GALYEAN, M.L. Protein levels in beef cattle finishing diets: Industry application, university research, and systems results. Journal of Animal Science, v.74, p.2860-2870, 1996.

GOERING, H.K.; VAN SOEST, P.J. Forage fiber analysis (Apparatus, reagents, procedures and some applications). Agricultural Handbook, Washington:D.C.: Agricultural Research Service, 1970. 19p.

GONÇALVES, J.R.S. Efeito da substituição do grão de milho pelo de milheto (Pennisetum americanum), em dietas de bovinos de corte em confinamento. Piracicaba, 2000. 70p. Dissertação (Mestrado) - Escola Superior de Agricultura “Luiz de Queiroz”, Universidade de São Paulo.

GREENWOOD, R.H.; TITGEMEYER, E.C. Limiting amino acid for growing Holstein steers limit-fed soybean hull-based diets. Journal of Animal Science, v.80, p.1997-2004, 2000.

GRISWOLD, K.E.; HOOVER, W.H.; MILLER, T.K.; THAYNE, W.V. Effect of from of nitrogen on growth of ruminal microbes in continuous culture. Journal of Animal Science, v.74, p.483-491, 1996.

HARDISON, W.A.; LINKOUS, W.N.; ENGEL, RW.; GRAF, G.E. Observation on the use of chromic oxide for estimating the fecal output of dairy animals. Journal of Dairy Science, v.42, n.2, p.345-352, 1959.

HAUSKNECHT, J.C.O.V. Efeito da fonte de fibra e do processamento físico do sorgo sobre o desempenho, digestibilidade e parâmetros ruminais de bovinos alimentados com rações a base de bagaço tratado sob pressão e vapor. Piracicaba, 1996. 86p. Dissertação (Mestrado) - Escola Superior de Agricultura "Luiz de Queiroz", Universidade de São Paulo. 
HEALY, B.J.; BRANDT Jr, R.T.; ECK, T.P. Combinations of non-protein nitrogen and natural protein effect performance of finishing steers fed flaked corn diets. Journal of Animal Science, v.73, p.258, 1995. Supplement, 1.

HELMER, L.G.; BARTLEY, E.E.; DEYOE, C.W. Feed processing. VI. Comparison of starea, urea, and soybean meal as protein sources for lactating dairy cows. Journal of Dairy Science, v.53, n.7, p.883-887, 1970a.

HELMER, L.G.; BARTLEY, E.E.; DEYOE, C.W.; MEYER, R.M; PFOST, H.B. Feed processing. 5. Effect of an expansion-processed mixture of grain and urea (starea) on nitrogen utilization in-vitro. Journal of Dairy Science, v.53, n.3, p.330-335, 1970b.

HENRIQUE, W.; LEME. P.R.; LANNA, D.P.D.; ALLEONI, G.F.; COUTINHO FILHO, J.L.V.; BELTRAME FILHO, J.A. Avaliação do milho úmido com bagaço de cana ou silagem de milho na engorda de bovinos. (Compact disc). I. Desempenho animal e características de carcaça. In: REUNIÃO ANUAL DA SOCIEDADE BRASILEIRA DE ZOOTECNIA, 36., Porto Alegre, RS, 1999. Anais. Porto Alegre, RS:SBZ, 1999.

HOOVER, W.H. Chemical factors involved in ruminal fiber digestion. Journal of Animal Science, v.69, p.2755-2766, 1986.

HOOVER, W.H.; WEBSTER, T.K.M. Contributions of microbial protein to aminoacid supply. In: CORNELL NUTRITION CONFERENCE. Ithaca, NY, 1996. Proceedings. Ithaca: Cornell University, 1996. p.199-207.

HOPPER, J.T.; HOLLOWAY, J.W.; BUTTS JR., W.T. Animal variation in chromium sesquioxide excretion patters of grazing cows. Journal of Animal Science, v.46, n.4, p.1098-1102, 1978. 
HUBER, J.T. Uréia ao nível do rúmen. In: SIMPÓSIO SOBRE NUTRIÇÃO DE BOVINOS, 2; Piracicaba, 1994. Anais. Piracicaba: FEALQ, 1994. p.1-17.

HUNT, C.W.; PARKINSON, J.F.; ROEDER, R.A.; FALK, D.G. The delivery cottonseed meal at three different time intervals to steers fed low-quality grass hay: Effects on digestion and performance. Journal of Animal Science, v.67, p.1360-1366, 1989.

HUNTINGTON, G. Hepatic urea synthesis and site and rate of urea removal from blood of beef steers fed alfalfa hay or a high concentrate diets. Canadian Journal of Animal Science, v.69, p.215-223, 1989.

HUNTINGTON, G.B.E.; POORE, M.; HOPKINS, B.; SPEARS, J. Effect of ruminal protein degradability on growth and $\mathrm{N}$ metabolism in growing beef steers. Journal of Animal Science, v.79, p.533-541, 2001.

HUNTINGTON, G.B.E.; ZETINA, E.J.; WHITT, J.M.; POTTS, W. Effects of dietary concentrate level on nutrient absorption, liver metabolism, and urea kinetics of beef steers fed isonitrogenous and isoenergetic diets. Journal of Animal Science, v.74, p.908-916, 1996.

HUSTON, J.E.; LIPPKE,H.; FORBES, A.; HOLLOWAY, J.W.; MACHEN, R.V. Effects of supplemental feeding interval on adult cows in western Texas. Journal of Animal Science, v.77, p.3057-3067, 1999.

IMAIZUMI, H. Avaliação de diferentes fontes e teores de proteína degradável no rúmen sobre o desempenho e parâmetros ruminais e sanguíneos de vacas Holandesas em final de lactação. Piracicaba, 2000. 69p. Dissertação (Mestrado) - Escola Superior de Agricultura "Luiz de Queiroz", Universidade de São Paulo. 
ÍTAVO, L.C.V.; SILVA, F.F.; FERREIRA, C.C.B.; VALADARES FILHO, S.C.; VALADARES, R.F.D.; PAULINO, P.V.R.; MORAES, E.H.B.K.; Indicadores internos para estimativas de produção fecal e digestibilidade de nutrientes em bovinos. (Compact disc). In: REUNIÃO ANUAL DA SOCIEDADE BRASILEIRA DE ZOOTECNIA, 38., Piracicaba, SP, 2001. Anais. Piracicaba, SP:SBZ, 2001.

ÍTAVO, L.C.V.; SILVA, F.F.; VALADARES FILHO, S.C.; MORAES, E.H.B.K.; PAULINO, P.V.R. Digestibilidade de fenos de gramíneas do gênero cynodon através de indicadores internos. (Compact disc). In: REUNIÃO ANUAL DA SOCIEDADE BRASILEIRA DE ZOOTECNIA, 37., Viçosa, MG, 2000. Anais. Viçosa, MG:SBZ, 2000.

ÍTAVO, L.C.V.; VALADARES FILHO, S.C.; SILVA, F.F.; VALADARES, R.F.D.; CECON, P.R.; ÍTAVO, C.C.B.F.; MORAES, E.H.B.K.; PAULINO, P.V.R. Consumo, degradabilidade ruminal e digestibilidade aparente de fenos de gramíneas do gênero cynodon e rações concentradas utilizando indicadores internos. Revista Brasileira de Zootecnia, v.31, n.2, p.10241032, 2002.

JONES, G.M.; STEPHENS, C.; KENSETT, B. Utilization of starea, urea, or soybean-meal in complete rations for lactating dairy-cows. Journal of Dairy Science, v.58, n.5, p.689-695, 1975. 
LANÇANOVA, J.A.C.; OLIVEIRA, M.D.S.; PACOLA, L.J.; VILELA, L.M.R.; SAMPAIO, A.A.M.; FIGUEIREDO, L.A.; RUGGIERI, A.C.; VIEIRA, P.F. Digestibilidade aparente do extrato etéreo, da proteína bruta e dos componentes da parede celular de uma ração completa, com zebuinos e taurinos. (Compact disc). In: REUNIÃO ANUAL DA SOCIEDADE BRASILEIRA DE ZOOTECNIA, 37., Viçosa, MG, 2000. Anais. Viçosa, MG:SBZ, 2000.

LAMEOURNE, L.J. Measurement of feed intake of grazing sheep. II. The estimation of feces output using markers. Journal of Agricultural Science, v.48, n.4, p.415-425. 1975.

LANNA, D.P.D.; BOIN, C. Efeito de bicarbonato de sódio, feno e bagaço in natura sobre a digestibilidade e o desempenho de zebuínos em crescimentos alimentados com bagaço de cana auto-hidrolizado. Anais Escola Superior de Agricultura “Luiz de QueiroZ”, v.47, p.417-434, 1990.

LEE, D.D.; STILES, D.A.; BARTLEY, E.E.; MCOOY, G.C.; MENO, J.J. Utilization of soybean-meal, urea, and starea by ruminants. Journal of Dairy Science, v.58, n.5, p.778, 1975.

LIMA, M.A.; VIANA, J.A.C.; RODRIGUES, N.M.; ESCUDER, C.J. O uso do óxido crômico para estimar a excreção fecal de novilhos zebus em pastejo. Revista da Sociedade Brasileira de Zootecnia, v.9, n.2, p.188-202, 1980.

LIPPKE, H., ELLIS, W.C., JACOBS, B.F. Recovery of indigestible fiber from feces of sheep and cattle on forage diets. Journal of Dairy Science, v.69, n.2, p.403-412, 1986. 
KING, K.W.; MOORE, E.C. Density and size as factors a affecting passage rate of ingest in the bovine and human digestive tracts. Journal of Dairy Science, v.40, n.5, p.528-536, 1957.

KLEMESRUD, M.J.; KLOPFENSTEIN, T.J.; LEWIS, A.J. Evaluation of feather meal as a source of sulfur amino acids for growing steers. Journal of Animal Science, v.78, p.207-215, 2000a.

KLEMESRUD, M.J.; KLOPFENSTEIN, T.J.; LEWIS, A.J. Metabolizable metionina and lysine requirements of growing cattle. Journal of Animal Science, v.78, p.199-206, 2000b.

KLEMESRUD, M.J.; KLOPFENSTEIN, T.J.; STOCK, R.A.; LEWIS, A.J.; HEROLD, D.W. Effect of dietary concentration of metabolizable lysine on finishing cattle performance. Journal of Animal Science, v.78, p.753-760, 2000c.

KLEMESRUD, M.J.; KLOPFENSTEIN, T.J.; LEWIS, A.J.; SHAIN, D.H.; HEROLD, D.W. Limiting amino acids in meat bone and poultry by-product meals. Journal of Animal Science, v.75, p.3294-3300, 1997.

KNAUS, W.F.; BEERMANN, D.H.; GUIROY, P.J.; BOEHM, M.L.; FOX, D.G. Optimization of rate and efficiency of dietary nitrogen utilization through the use of animal by-products and (or) urea and their effects on nutrient digestion in Holstein steers. Journal of Animal Science, v.78, p.1060-1066, 2001.

KORNDORFER, C.M.; ABDALLA, A.L.; BUENO, I.C.S.; NASCIMENTO JUNIOR, V.F.; OWEN, E.; SUTTON, J.D. Estudo da cinética digestiva em ovinos alimentados com braquiária e alfafa, usando a técnica de fluorescência de raios X. Veterinária Notícias, v.7, n.2, p.113-121, 2001. 
KÖSTER, H.H.; WOODS, B.C.; COCHRAN, R.C.; VANZANT, E.S.; TITGEMEYER, E.C.; GRIEGER, D.M.; OLSON, K.C.; STOKKA. G. Effect of increasing proportion of supplemental $\mathrm{N}$ from urea in prepartum supplements on range beef cows performance and on intake and digestibility by steers fd low-quality forage. Journal of Animal Science, v.80, p.1652-1662, 2002.

KREHBIEL, C.R.; KREIKEMEIER, K.K.; FERRELL, C.L. Influence of Bos indicus crossbreeding and cattle age on apparent utilization of a high-grain diet. Journal of Animal Science, v.78, p.1641-1647, 2000.

MAIA, R.L.A.; TEIXEIRA, J.C.; PÉREZ. J.R.O.; VILELA, E.R. Avaliação da qualidade da amiréia (produto da extrusão amido-uréia) através do método de estimativa da produção de proteína microbiana "in vitro". In: REUNIÃO ANUAL DA SOCIEDADE BRASILEIRA, 23., Brasília, DF, 1987. Anais. Brasília, DF:SBZ, 1987. p.95.

MAKKAR, H.P.S.; LALL, D.; NEGI, S.S. Complexes of urea and formaldehyde as non-protein nitrogen compounds in ruminant ration: a review. Animal Feed Science and Technology, v.20, n.1, p.1-12, 1988.

MARTHIS, C.P.; COCHRAN, R.C.; HELDT, J.S.; WOODS, C.B.; ABDELGADIR, I.E.O.; OLSON, K.C.; TINGEMEYER, E.C.; VANZANT, E.S. Effects of supplemental degradable intake protein on utilization of medium- to low quality forages. Journal of Animal Science, v.78, p.224-232, 2000.

MATTOS, W.; PALMQUIST, D.L. Increased polyunsaturated fatty acid yields in milk of cows fed protected fat. Journal of Dairy Science, v.57, p.1050-1054, 1974. 
MEHREZ, A.Z.; ØRSKOV, E.R.; McDONALD, I. Rates fermentation in relation to ammonia concentration. The British Journal of Nutrition, v.38, n.3, p.437443, 1977.

MENDES, A.R.; EZEQUIEL, J.M.B.; GALATI, R.L.; BOCCHI, A.L.; FEITOSA, J.V. Comparação de três diferentes indicadores internos na estimativa da digestibilidade parcial e total de novilhos. (Compact disc). In: REUNIÃO ANUAL DA SOCIEDADE BRASILEIRA DE ZOOTECNIA, 38., Piracicaba, SP, 2001. Anais. Piracicaba, SP:SBZ, 2001.

MENDES JUNIOR, M.P. Efeito do processamento do grão de milho e sua substituição parcial por polpa de citros peletizada sobre o desempenho, digestibilidade de nutrientes e parâmetros sanguíneos de vacas de leite. Piracicaba, 1999. 97p. Dissertação (Mestrado) - Escola Superior de Agricultura "Luiz de Queiroz", Universidade de São Paulo.

MERCHEN, N.R. Digestion, absorption and excretion in ruminants. In: $\mathrm{CHURCH}$, D.C. (Ed.). The ruminant animal: digestive physiology and nutrition. New Jersey: Prentice Hall, 1988. p.171-201.

MERTENS, D.A. Analysis of fiber in feeds and its use in feed evaluation and ration formulation. In: SIMPÓSIO INTERNACIONAL DE RUMINANTES, Lavras, 1992. Anais. Lavras: SBZ, 1992. p.1-32.

MILTON, C.T.; BRANDT JUNIOR, R.T.; TITGEMEYER, E.C. Effects of dietary source and concentration in high-grain diets on finishing steer performance and nutrient digestion. Journal of Animal Science, v.75, n.10, p.2813-2823, 1997a. 
MILTON, C.T.; BRANDT JUNIOR, R.T.; TITGEMEYER, E.C. Urea in dry-rolled corn diets: finishing steer performance, nutrient digestion, and microbial protein production. Journal of Animal Science, v.75, p.1415-1424, 1997b.

MIZWICKI, K.L.; OWENS, F.N.; POLING, K.; BURNETT, G. Timed ammonia release for steers. Journal of Animal Science, v.51, n.3, p.698-703, 1980.

MORRILL, J.L.; DAYTON, A.D. Soybean-meal versus starea at 2 concentrations for young calves. Journal of Dairy Science, v.57, n.4, p.427-429, 1974.

MUNTIFERING, R.B. Evaluation of various lignin assays for determining ruminal digestion of roughages by lambs. Journal of Animal Science, v.55, n.2, p.432-438, 1982.

NASCIMENTO FILHO, V.F. Técnicas analíticas nucleares de fluorescência de raios $X$ por dispersão de energia (ED-XRF) e por reflexão total (TXRF), 1999, http://web.cena.usp.br/apostilas/Virgilio/cen5723/EDXRF_TXRF.doc, (12 jun. 2002).

NATIONAL RESEARCH COUNCIL. Nutrient Requirements of Beef Cattle. 6.ed. Washington: National Academy Press, 1984. 90p.

NATIONAL RESEARCH COUNCIL. Ruminant Nitrogen Usage. Washington: National Academy Press, 1985. 138p.

NATIONAL RESEARCH COUNCIL. Nutrient Requirements of Beef Cattle. 7.ed. Washington: National Academy Press, 1996. 242p.

NATIONAL RESEARCH COUNCIL. Nutrient requirement of dairy cattle. 7.ed. Washington: National Academic Press, 2001. 381p. 
NELSON, M.L.; MOTJOPE, L.; FINLEY, J.W. et al. Ash free indigestible acid detergent fiber as an internal marker to estimate digestibility wither grazing ruminants. Journal Range Management, v.43, n.3, p.224-229, 1990.

NOCEK, J.E.; TAMMINGA, S. Site of digestion of starch in the gastrointestinal tract of dairy cows and its effect on milk yield and composition. Journal of Dairy Science, v.74, p.3598-3629, 1991.

NUSSIO, L.G. Efeitos de níveis de concentrado sobre o desempenho de bovinos e a digestibilidade de dietas à base de bagaço de cana-de-açúcar (Saccharum sp. L) tratado sobre pressão e vapor. Piracicaba, 1993. 147p. Dissertação (Mestrado) - Escola Superior de Agricultura "Luiz de Queiroz", Universidade de São Paulo.

NUSSIO, L.G.; SILVA, S.C.; BOIN, C.; SANTOS, F.A.P. Avaliação do uso de bicarbonato em dietas com bagaço de na auto-hidrolizado no desempenho de bovinos confinados. In: REUNIÃO ANUAL DA SOCIEDADE BRASILEIRA DE ZOOTECNIA, 27., Campinas, SP, 1990. Anais. Campinas, SP:SBZ, 1990. p.18.

OLIVEIRA, L.O.F. Influência da suplementação de novilhos nelore com misturas múltiplas, em pastagem de Brachiaria brizantha CV Marandu. Belo Horizonte, 2001a. 58p. Dissertação (Mestrado) - Universidade Federal de Minas Gerais.

OLIVEIRA, S.G. Utilização de fontes de gordura em dietas com diferentes níveis de fibra para vacas em lactação. Piracicaba, 2001b. 67p. Dissertação (Mestrado) - Escola Superior de Agricultura "Luiz de Queiroz", Universidade de São Paulo. 
OLIVEIRA JUNIOR, R.C. Efeitos de níveis de grão de soja na digestibilidade de nutrientes e no desempenho da lactação de cabras leiteiras. Piracicaba, 1999. 67p. Dissertação (Mestrado) - Escola Superior de Agricultura "Luiz de Queiroz", Universidade de São Paulo.

OLIVEIRA, R.F.M.; FONTES, C.A.A.; SILVA, J.F.C. Estudo da recuperação fecal do $\mathrm{Cr} 2 \mathrm{O} 3$ e dos indicadores internos CIA e CIDA e lignina em períodos de coleta de dois a sete dias, em bovinos. Revista da Sociedade Brasileira de Zootecnia, v.20, n.5, p.522-531, 1991.

OLIVEIRA, D.E,; MEDEIROS, S.R.; AROEIRA, L.J. M.; LANNA, D.P.D. Padrão da excreção fecal de cromo utilizado como indicador externo para estimativa da produção fecal. (Compact disc). In: REUNIÃO ANUAL DA SOCIEDADE BRASILEIRA DE ZOOTECNIA, 38., Piracicaba, SP, 2001. Anais. Piracicaba, SP:SBZ, 2001.

ØRSKOV, E.R. Nutrición proteica de los rumiantes. Zaragosa: ACRIBIA, 1988. 178p.

ØRSKOV, E.R.; McDONALD, I. The estimation of protein degradability in the rumen from incubation measurements weighed according to rate of passage. Journal of Agriculture Science, v.92, p.499-503, 1979.

OWENS, F.N.; GOETSCH, A.L. Ruminal fermentation. In: $\mathrm{CHURCH,} \mathrm{D.C.} \mathrm{(Ed.).}$ The ruminant animal: digestive physiology and nutrition. Englewood Cliffs: Simon \& Schuster, 1988. cap.8, p.145-171.

OWENS, F.N; HANSON, C.F. External and internal markers for appraising site and extent of digestion in ruminants. Journal of Dairy Science, v.79, n.9, p.2605-2617, 1992. 
OWENS, F.N; LUSBY, K.S.; MIZWICKI, K.; FORERO, O. Slow ammonia release from urea: rumen and metabolism studies. Journal of Animal Science, v.50, n.3, p.527-531, 1980.

OWENS, F.N.; ZINN, R. Protein metabolism of ruminant animal. In: $\mathrm{CHURCH}$, D.C. (Ed.). The ruminant animal: digestive physiology and nutrition. Englewood Cliffs: Simon \& Schuster, 1988. cap.12, p.227-249.

PALMQUIST, D.L.; CONRAD, H. Origin of plasma fatty acids in lactating cows fed high fat diets. Journal of Dairy Science, v.54, n.3, p.1025-1033, 1971.

PAZIANI, S.F.; BERCHIELLI, T.T.; ANDRADE, P.; FREITAS, D.; SILVEIRA, R.N. Digestibilidade de rações à base de milho desintegrado com palha e sabugo em diferentes granulometrias. (Compact disc). In: REUNIÃO ANUAL DA SOCIEDADE BRASILEIRA DE ZOOTECNIA, 37., Viçosa, 2000. Anais. Viçosa: Sociedade Brasileira de Zootecnia, 2000.

PIAGGIO, L.M; PRATES, E.R.; PIRES, F.F. OSPINA, H. Avaliação das cinzas insolúveis em ácido, fibra, em detergente ácido indigestível e lignina em detergente ácido indigestível com indicadores internos da digestibilidade. Revista da Sociedade Brasileira de Zootecnia, v.20, n.3, p.306-312, 1991.

PITT, R.E.; VAN KESSEL, J.S.; FOX, D.G.; PELL, AN.; BARRY, M.C.; VAN SOEST, P.J. Prediction of ruminal volatile fatty acids and $\mathrm{pH}$ within the Net Carbohydrate and Protein System. Journal of Animal Science, v.74, p.226244, 1996.

POLAN, C.E. Protein and amino acids for lactating cows. In: VAN HORN, H.H.; WILCOX, C.J. Large dairy herd management. Champaign: American Dairy Science, 1992. cap.26, p.336-347. 
PRESTON, R.L. Management of high concentrate diets in feedlot. In: CONGRESSO BRADILEIRO DE NUTRIÇÃO ANIMAL, Campinas, 1998. Anais. Campinas: CBNA, 1998. p.82-91.

RABELO, M.M.A. Efeitos de fontes e neveis de fibra íntegra, em dietas contendo bagaço de cana-de-açúcar tratado sob pressão e vapor, sobre a digestibilidade, desempenho e comportamento ingestivo de bovinos de corte. Piracicaba, 2002. 61p. Dissertação (Mestrado) - Escola Superior de Agricultura “Luiz de Queiroz", Universidade de São Paulo.

RANDEL, P.F.; VAN HORN, H.H.; WILCOX, C.J.; ROMAN-PONCE, H.; MARSHALL, S.P.; BACHMAN, K.C. Complete rations for dairy cattle. IV. Comparison of supplemental nitrogen source by metabolizable protein concept. Journal of Dairy Science, v.58, n.8, p.1109-1117, 1975.

REDMAN, R.G.R.; KELLAWAY, R.C.; LEIBHOLZ, J. Utilization of low quality roughages: Effects of urea and protein supplements of differing solubilities on digesta flow, intake and growth rate of cattle eating oaten chaff. The British Journal of Nutrition, v.44, p.343-354. 1980.

RIBEIRO, C.V.M. Efeito da Substituição do grão de milho pelo de milheto (Pennisetum americanum) na dieta de vacas em lactação. Piracicaba, 1999. 67p. Dissertação (Mestrado) - Escola Superior de Agricultura "Luiz de Queiroz", Universidade de São Paulo.

ROFFLER, R.E.; SATTLER, L.L. Relationship between ruminal ammonia and nonprotein nitrogen utilization by ruminants. I. Development of a model br predicting nonprotein nitrogen utilization by cattle. Journal of Dairy Science, v.58, p.1880-1888, 1975. 
ROMAN-PONCE, H.; VAN HORN, H.H.; MARSHALL, S.P.; WILCOX, C.J.; RANDEL, P.F. Complete rations for dairy-cattle .5. interaction of sugarcane bagasse quantity and form with soybean-meal, urea, and starea. Journal of Dairy Science, v.58, n.9, p.1320-1327, 1975.

RUSSEL, J.B. Factors influencing rumen microbial growth and protein yield. In: SOUTHWEST NUTRITION MANAGEMENT CONFERENCE, Arizona, 1994. Proceedings. Arizona: University of Arizona,1994. p.1-6.

RUSSEL, J.B.; O`CONNOR, J.D.; FOX, D.G.; VAN SOEST, P.J.; SNIFFEN, C.J. A net carbohydrate and Protein System for evaluating cattle diets: I. Ruminal fermentation. Journal of Animal Science, v.70, p.3551-3561, 1992.

RUSSEL, J.B.; SNIFFEN, C.J; VAN SOEST, P.J. Effect the carbohydrate and limitation on degradation and utilization of casein by mixed rumen bacteria. Journal of Dairy Science, v.66, p.763-775, 1983.

SALMAN, A.K.D.; MATARAZZO, S.V.; EZEQUIEL, J.M.B.; KRONKA, S.N.; SEIXAS, J.R.C.; SOARES, W.V.B.; MARTINS JÚNIOR, A.P. Estudo do balanço nitrogenado e da digestibilidade da matéria seca e proteína de rações, para ovinos, suplementadas com amiréia, uréia ou farelo de algodão. Revista Brasileira de Zootecnia, v.26, n.1, p.179-185, 1997.

SANTOS, F.A.P. Efeito de bicarbonato de sódio, lasalocida e cana-de-açúcar sobre o desempenho de bovinos alimentados com bagaço de cana tratado sob pressão e vapor. Piracicaba, 1991. 127p. Dissertação (Mestrado) Escola Superior de Agricultura “Luiz de Queiroz”, Universidade de São Paulo. 
SANTOS, F.A.P. Conceitos atuais de nutrição protéica. In: SIMPÓSIO SOBRE PRODUÇÃO ANIMAL, 9., Piracicaba, 1997. Anais. Piracicaba: FEALQ, 1997. p.50-67.

SANTOS, F.A.P. Efeito de fontes protéicas e processamento de grãos no desempenho de vacas leite e digestibilidade dos nutrientes. Piracicaba, 1998. 105p. Tese (Livre Docência) - Escola Superior de Agricultura "Luiz de Queiroz", Universidade de São Paulo.

SARRASECA, A.E.; MILNE, M.J.; METCALF, M.J.; LOBLEY, G.E. Urea recycling in sheep: Effects of intake. The British Journal of Nutrition, v.79, p.79-88, 1998.

SAS Institute. SAS/STAT User's guide. Cary: Statistical Analysis System Institute, 1988.

SCHMIDT, S.P.; JORGENSE, N.A.; BENEVENG, N.J.; BRUNGARD, V.H. Comparison of soybean-meal, formaldehyde treated soybean-meal, urea and starea for steers. Journal of Animal Science, v.37, n.5, p.1233-1237, 1973.

SCHWAB, C.G. Optimizing amino acid nutrition for optimum yields of milk and milk protein. In: SOUTHWEST NUTRITION MANAGEMENT CONFERENCE, Arizona, 1994. Proceedings. Arizona: University of Arizona, 1994. p.114129.

SECRIST, D.S.; OWENS, F.N.; HILL, W.J. Protein level for feedlot steers fed high moisture corn. Journal of Animal Science, v.73, p.101, 1995. 
SEIXAS, J.R.C.; EZEQUIEL, J.M.B.; ARAÚJO, W.D.; RESENDE, F.D.; MARTINS JÚNIOR, A.; KRONKA, S.N.; DaSILVA, L.D.F.; DOURADO, J.B.; SOARES, W.V.B. Desempenho de bovinos confinados alimentados com dietas à base de farelo de algodão, uréia ou amiréia. Revista Brasileira de Zootecnia, v.28, n.2, p.432-438, 1999.

SHAIN, D.H.; STOCK, R.A.; KLOPFENSTEIN, T.J.; HEROLD, D.W. Effect of degradable intake protein level on fishing cattle performance and ruminal metabolism. Journal of Animal Science, v.76, p.242-248, 1998.

SILVA, D.J. Análise de Alimentos: métodos químicos e biológicos. Viçosa, MG: UFV, 1990, 166p.

SILVA, J.F.C; PEREIRA, J.C.; VALADARES FILHO, S.C.; VILELA, L.M.R.; LOMBARDI, C.T. Valor nutritivo da palha de arroz suplementada com amiréia, fubáturéia e farelo de soja. Pesquisa Agropecuária Brasileira, v.29, n.9, p.1475-14881, 1994.

SILVA, L.D.F.; EZEQUIEL, J.M.B.; AZEVEDO, P.S.; CATTELAN, J.W.; BARBOSA, J.C.; RESENDE, F.D.; CARMO, F.R.G. Digestão total e parcial de alguns componentes de dietas contendo diferentes níveis de casca de soja e fontes de nitrogênio em bovinos. Revista Brasileira de Zootecnia, v.31, n.3, p.1258-1268, 2002.

SILVA, L.D.F. Degradabilidade ruminal da casca de soja e fontes protéicas e seus efeitos nas digestões ruminal e intestinal de rações de bovinos. Jaboticabal, 1999. 110p. Tese (Doutorado) - Faculdade de Ciências Agrárias e Veterinárias, Universidade Estadual Paulista "Julio de Mesquita Filho". 
SIMAS, J.M. Processamento de grãos para rações de vacas leiteiras. In: SIMPÓSIO SOBRE PRODUÇÃO ANIMAL, 9., Piracicaba, 1997. Anais. Piracicaba: FEALQ, 1997. p.7-32.

SIMAS, J.M.C. Effect of sorghum grain processing and fat supplementation on performance and nutrient utilization in lactating dairy cows. Tucson, 1995. 147p. Thesis (PhD) - University of Arizona.

SHIEHZADEH, S.A.; HARBERS, L.H. Soybean meal, urea and extruded starchurea products compared as protein supplements in high-roughage lamb rations. Journal of Animal Science, v.38, n.1, p.206-212, 1974.

SMITH, R.H. Synthesis of microbial nitrogen compounds in the rumen and their subsequent digestion. Journal of Animal Science, v.49, p.1604-1611, 1979.

SNIFFEN, C.J.; O'COMMOR, J.D.; VAN SOEST, P.J.; FOX, D.G.; RUSSELL, J.B.; A net-carbohydrate and protein system for evaluating cattle diets: II. Carbohydrate and protein availability. Journal of Animal Science, v.70, p.3562-3577, 1992.

STAPLES, C.R.; GARCIA-BOJALIL, C.; OLDICK, B.S.; THATCHER, W.W.; RISCO, C.A. Protein intake and reproductive performance of dairy cows: a review, a suggested mechanism, and blood and milk urea measurements. In: ANNUAL FLORIDA RUMINANT NUTRITION SYMPOSIUM, 4., Gainesville, FL, 1993. Proceedings. Gainesville: University of Florida, 1993. p.37-52.

STILES, D.A.; BARTLEY, E.E.; MEYER, R.M.; DEYOE, C.V.; PFOST, H.B. Feed processing. VII. Effect of an expansion-processed mixture of grain and urea (starea) on rumen metabolism in cattle and on urea toxicity. Journal of Dairy Science, v.53, n.10, p.1436-1447, 1970. 
STILES, D.A.; LEE, D.D.; BARTLEY, E.E. Starea, soybean-meal, and urea as nitrogen-sources for lactating cows. Journal of Dairy Science, v.58, n.5, p.777-778, 1975a.

STILES, D.A.; LEE, D.D.; BARTLEY, E.E. Starea, soybean-meal, and urea as nitrogen-sources for lactating cows. Journal of Dairy Science, v.58, n.5, p.777-778, 1975b.

SWENSON, M.J.; REECE, W.O. Dukes / Fisiologia dos Animais Domésticos. 11.ed. Rio de Janeiro: Guanabara Koogan, 1996. 856p.

TEDESCHI, L.O. Development and evaluation of models for the Cornell Net Carbohydrate and Protein System: 1. Feed libraries, 2. Ruminal nitrogen and Branched-chain volatile fatty acid deficiencies, 3. Diet optimization, 4. Energy requirement for maintenance and growth. Ithaca, 2001. 414p. Thesis (PhD) Cornell university.

TEDESCHI, L.O.; FOX, D.G.; RUSSELL, J.B. Accounting for the effects of a ruminal nitrogen deficiency within the structure of the Cornell Net Carbohydrate and Protein System. Journal of Animal Science, v.78, p.1648-1658, 2000.

TEDESCHI, L.O.; BOIN, C.; FOX, D.G.; LEME, P.R.; ALLEONI, GF.; LANNA, D.P.D. Energy requirement for maintenance and growth of Nellore bulls and steers fed high-forage diets. Journal of Animal Science, v.80, p.1671-1682, 2002.

TEIXEIRA, J.C.; DELGADO, E.F; CORREA, E.M.; MORON, I.R. Cinética da digestão ruminal da amiréia $45-\mathrm{S}$ em vacas da raça holandesa. Ciência e Agrotecnologia, v.23, n.3, p.719-723, 1999. 
TEIXEIRA, J.C.; EVANGELISTA, A.R.; ALQUERES, M.M.; BARBOSA, A.C.; REIS, S.T.; PAIVA, A.C.; COSTA, G.R.; MORON, I.R. Utilização da amiréia150s como suplemento nitrogenado para bovinos em sistema de pastejo. (Compact disc). In: REUNIÃO ANUAL DA SOCIEDADE BRASILEIRA, Botucatu, 1998. Anais. Botucatu: Sociedade Brasileira de Zootecnia, 1998.

TEIXEIRA, J.C.; PEREZ, J.R.O.; MORON, I.R.; VEIGA, R.D.; SANTOS, R.M. Aproveitamento do macho leiteiro utilizando dietas à base de amirea 45S. II Desempenho. Ciência e Agrotecnologia, v.24, n.1, p.203-207, 2000.

TEIXEIRA, J.C.; SANTOS, R.M.; PEREZ, J.R.O.; VEIGA, R.D.; MORON, I.R. Aproveitamento do macho leiteiro utilizando dietas à base de amirea 45S. I Biometria do trato gastrointestinal e características de carcaça. Ciência e Agrotecnologia, Lavras, v.23, n.2, p.421-426, 1999.

TELLER, E.; GODEAU, J.M. Some attempts to improve the nutritive value of urea for dairy cows. 3. Its adjunction to fermentable carbohydrates: starea. Archiv fur Tierernahrung - Archives of Animal Nutrition v.36, n.6, p.541$550,1986$.

TELLER, E.; GODEAU, J.M.; DEBAERE, B. La substitution du "starea" aux tourteaux dans les rations pour vaches en lactation. Revue de l'Agriculture, v.35, n.6, p.3171-3179, 1982.

THEURER, C.B.; HUNTINGTON, G.B.; HUBER, J.T.; SWINGLE, R.S.; MOORE, J.A. Net absorption and utilization of nitrogenous compounds across ruminal, intestinal, and hepatic tissues of growing beef steers fed dryrolled or steam-flaked sorghum grain. Journal of Animal Science, v.80, p.525-532, 2002. 
THIAGO, L.R.L.S.; SILVA, J.M. Suplementação de bovinos em pastejo. Campo Grande: Embrapa Gado de Corte, 2001. 28p. (Documentos / Embrapa Gado de Corte, 108)

THIAGO, L.R.L.S.; SILVA, J.K.; COSTA, F.P.; CORRÊA, F.S. Engorda de novilhos em confinamento utilizando subprodutos de microdestilarias de álcool. In: REUNIÃO ANUAL DA SOCIEDADE BRASILEIRA, Pelotas, 1983. Anais. Pelotas: Sociedade Brasileira de Zootecnia, 1983. p.100.

THOMPSON, L.H.; WISE, M.B.; BARRICK, E.R.; HARVEY, R.W. Starea, urea and sulfur in beef-cattle rations. Journal of Animal Science, v.35, n.2, p.474-480, 1972.

THONNEY, M.L.; DUHAIME, D.J.; MOE, P.W.; REID, J.T. Acid insoluble ash and permanganate lignin as indicators to determine digestibility of cattle rations. Journal of Animal Science, v.49, n.4, p.1112-16, 1979.

VALADARES, R.F.D; GONÇALVES, L.C.; RODRIGUEZ, N.M.; SAMPAIO, I.B.; VALADARES FILHO, S.C. Metodologia de coleta de urina em vacas utilizando sondas de folley. Revista Brasileira de Zootecnia, v.26, n.6, p.1297-1282, 1997b.

VALADARES, R.F.D; GONÇALVES, L.C.; SAMPAIO, I.B.; RODRIGUEZ, N.M.; DaSILVA, J.F.C. Níveis de proteína em dietas de bovinos. 2. Consumo, digestibilidade e balanço de compostos nitrogenados. Revista Brasileira de Zootecnia, v.26, n.6, p.1259-1263, 1997a. 
VALADARES FILHO, S.C.; SILVA, J.F.C.; LEÃO, M.I.; CASTRO, A.C.G.; SILVA, M.A. Óxido crômico e lignina na determinação dos fluxos de matéria seca abomasal, ileal e fecal em bovinos e bubalinos. Revista Sociedade Brasileira de Zootecnia, v.14, n.5, p.565-574, 1985.

VALADARES FILHO, S.C.; SILVA, J.F.C.; LEÃO, M.I.; EUCLYDES, R.F.; VALADARES, R.F.D.; CASTRO, A.C.G. Degradabilidade "in situ" da matéria seca e proteína bruta de vários alimentos em vacas em lactação. Revista da Sociedade Brasileira de Zootecnia, v.19, n.6, p.512-522, 1990.

VAN SOEST, P.J. Nutrition ecology of the ruminant. 2.ed. Ithaca: Cornell University Press, 1994. 476p.

VAN SOEST, P.J.; ROBERTSON, J.B.; LEWIS, B.A. Methods for dietary fiber, neutral detergent fiber, and nonstarch polysaccharides in relation to animal nutrition. Journal of Dairy Science, v.74, p.3583-3597, 1991.

VISEK, W.J. Ammonia: Its effects on biological systems, metabolic hormones, and reproduction. Journal of Dairy Science, v.67, n.3, p.481-498, 1984.

ZEOULA, L.M.; DIAN, P.H.M.; CALDAS NETO, S.F.; PRADO, I.N.; GERON, L.J.V.; FALCÃO, A.J.S.; PERON, P.D.P. Avaliação de indicadores internos em ensaios de digestibilidade para ruminantes. (Compact disc). In: REUNIÃO ANUAL DA SOCIEDADE BRASILEIRA DE ZOOTECNIA, 38., Piracicaba, SP, 2001. Anais. Piracicaba, SP:SBZ, 2001.

ZINN, R.A. Reevaluation of urea in feedlot diets. In: SOUTHWEST NUTRITION MANAGEMENT CONFERENCE, Arizona, 1994. Proceedings. Arizona: University of Arizona, 1994. p.17-28. 
ZINN, R.A.; OWENS, F.N. Ruminal escape protein for lightweight feedlot calves. Journal of Animal Science, v.71, p.1677-1687, 1993.

ZINN, R.A.; SHEN, Y. An evaluation of ruminally degradable intake protein and metabolizable amino acid requirements of feedlot calves. Journal of Animal Science, v.76, p.1280-1289, 1998.

WILSON, B.B.; WOODS, W. Effect of level of gelatinized corn upon animal performance and rumen fermentation. Journal of Animal Science, v.25, p.912-912, 1966.

WILSON, B.B.; WOODS, W. Effect of increasing levels of gelatinized corn upon rumen metabolism. Journal of Animal Science, v.26, p.932-932, 1967.

WOODY, H.D.; FOX, D.G.; BLACK, J.R. Effects of diet grain content on performance of growing and finishing cattle. Journal of Animal Science, v.57, p.717-726, 1983.

WRINGHT, J.; TOTUSEK, R. Urea starea and biuret in rage supplements. Journal of Animal Science, v.40, p.194-194, 1975. 